\title{
LIETUVOS KARIUOMENĖS GYNYBOS PLANAI IR PRIEMONĖS GALIMAI LENKU AGRESIJAI ATREMTI 1921-1937 M.
}

\author{
Doc. dr. Vytautas Lesčius
}

\section{IVADAS}

1920 m. pabaigoje pasibaigęs Nepriklausomybès karas lietuvių tautai ir jos ginkluotosioms pajegoms suteikè vilties pereiti prie ramaus kuriamojo darbo. Besikeičiančiomis aplinkybėmis jaunai Lietuvos valstybei iškilo nauji dideli uždaviniai: greičiau užgydyti Pirmojo pasaulinio karo, vokiečių okupacijos ir Laisvès kovų žaizdas, atkurti sugriautą krašto ūkì, ịvykdyti būtinas reformas visose gyvenimo srityse, stiprinti valstybę, didinti jos gynybinị pajègumą, tvirtai ịsilieti ị laisvų Europos valstybių sąjungą.

Nors tų metų lapkričio 29 d. Kaune, dalyvaujant keturiems Tautų Sąjungos karinès kontrolès komisijos nariams, buvo pasirašyta paliaubų sutartis dèl iki tol su želigovskininkais vykusių karo veiksmų nutraukimo ir neutraliosios zonos tarp Lietuvos ir Lenkijos kariuomenių nustatymo, dèl Vilniaus krašto užgrobimo tarp abiejų šalių ịsitvirtino ilgalaikẻ nesantaika ir priešprieša. Tai buvo užsitęsusi lietuvių kova dèl Vilniaus krašto atgavimo ir griežtas atsisakymas turèti su agresoriumi diplomatinių santykių, nepaisant nuolatinio Lenkijos spaudimo išgauti iš Lietuvos oficialų Vilniaus aneksijos pripažinimą. Dèl tokios Lenkijos valdančiųjų sluoksnių pozicijos šis dviejų šalių konfliktas liko neišspręstas per visą tarpukario laikotarpi.

Lenkijos valdžia, ir toliau laikydama Lietuvą tik laikinąja valstybe, susitarimo dèl neutraliosios zonos nustatymo nesilaikè ir beveik nuo pat pirmos dienos ji pažeidinèjo. Visokiais būdais didindama ịtampą šioje zonoje, ji siekè išprovokuoti lietuvių kariuomenès atsakomuosius veiksmus ir, Tautų Sąjungai apkaltinusi ją tariamu paliaubų susitarimo nesilaikymu, pasiųsti ị Lietuvos gilumą Vilniaus krašte sutelktas dideles ginkluotąsias pajègas. 
Per visą tarpukario laikotarpị Lietuvos pasienyje dažnai lenkų kariuomene buvo pergrupuojama, vyko provokaciniai kariniai manevrai Pabradeje, prie Valkininkų ir kitose pasienio vietose. Juose dalyvaudavo gausios ịvairių ginklo rūšiu (net ir aviacijos!) pajègos. Be to, okupuotame Vilniaus krašte veikè daugybẻ karinių lenkų organizacijų, kurių uždavinys buvo prieš Lietuvą vesti kuo plačiausią ir Lenkijai palankiausią agitaciją, ruoštis karui ir nę̧sileisti lietuvių kariuomenès tuo atveju, jeigu Lenkijos ginkluotosios pajègos Tautų Sąungos būtų priverstos pasitraukti iš užgrobtos teritorijos.

Be to, Lenkija, konfliktuodama su maža, beveik niekieno nepripažinta valstybe, visokiais būdais ją žemino, stengèsi sukliudyti įstoti ị Tautų Sąjungą irodinèdama, jog geriausias būdas - ginklu spręsti prieštaravimus su Lietuva.

Okupavusi ir aneksavusi Vilnių Lenkija padarè nepataisomą žalą Lietuvos ir Lenkijos santykiams. Po Vilniaus aneksijos Lenkija Lietuvoje imta traktuoti kaip didžiausios grèsmès valstybès teritoriniam vientisumui ir suverenitetui šaltinis. Tarpukariu Lenkijos grèsmè laikyta nuolatine.

Lietuvos valstybès ir kariuomenès vadovai negalèjo būti abejingi Lenkijos valdančiụjų sluoksnių agresyviems siekiams. Jie atidžiai sekè ịvykius pasienyje ir netrukus buvo priversti imtis visų galimų priemonių (tiek diplomatinių, tiek karinių) krašto nepriklausomybei ginti.

Jau Lietuvos tarpukario istoriografijoje gana plačiai aptarta konflikto su Lenkija eiga. Pirmieji autoriai savo populiariuose darbuose, skirtuose šio konflikto istorijai atskleisti, nagrinèjo Vilniaus politinès priklausomybès klausimą ${ }^{1}$. Beveik visi tyrimų, kurie skirti plačiajai visuomenei, tikslas buvo pagrịsti istorines Lietuvos teises ị Vilnių ir Vilniaus kraštą. Šio laikotarpio istoriografija nepasižymi nuomonių ir koncepcijų ivairove. Autoriai išreiške praktiškai visos to meto šalies visuomenès pasiryžimą kovoti dèl Vilniaus atgavimo, pabrèždami jo ir Lietuvos ekonominio organizmo nedalomumą.

Politini atspalvị turëjo ne tik Lietuvos, bet ir tarpukario Lenkijos istoriografija. Autoriai visokeriopai stengèsi ịrodyti Lenkijos istorines, juridines teises $\mathfrak{i}$ Vilnių arba net $\mathfrak{i}$ visą Lietuvos teritoriją. Daugelyje jų darbų

1 P. Klimas, Mūsų kovos dèl Vilniaus 1323-1923, Kaunas, 1923; Vilnius ir Vilniaus kraštas, Kaunas, 1932; Vilniaus kraštas nuo amžiu lietuviškas, Kaunas, 1936; Z. Žemaitis, Vilnius Lietuvai ir Lietuva Vilniui, Kaunas, 1928; Kovoje dèl Vilniaus, Kaunas, 1921, ir kt. 
net nemėginta ieškoti tikrųjų abiejų šalių valdančiųjų sluoksnių nesantaikos priežasčių, tiesiog skiepijamas nacionalizmas, ugdoma vienos tautos neapykanta kitai.

Tam tikras požiūrio ị Lietuvą pokytis lenkų istoriografijoje įvyko pokario metais. Pasikeitè Lietuvos ir Lenkijos politinė orientacija, buvo išspręsti seni konfliktai, nubrèžtos naujos valstybių sienos. Iš šio laikotarpio lenkų istorikų tyrimų išskirtini P. Losovskio darbai. Viename iš $\mathrm{juc}^{2}$ autorius, nuodugniai išanalizavęs šaltinius, kritiškai juos ịvertinęs, $\mathfrak{i}$ mokslinę apyvartą ịtraukęs daug naujų faktų, atskleidęs kai kuriuos Lenkijos diplomatijos užkulisius, padeda skaitytojui susidaryti gana išsamų tarpukario Lenkijos politikos Lietuvos atžvilgiu vaizdą.

Ši problema susilaukè ir Lietuvos istorikų dėmesio. Bene daugiausia tuo metu šioje srityje nuveikè istorikė R. Žepkaitė, parengusi keletą monografijų. Iš jų pirmiausia išskirtini du darbai: „Diplomatija imperializmo tarnyboje. Lietuvos-Lenkijos santykiai 1919-1939 m.“ ir „Lietuva ir didžiosios valstybès 1918-1940 m.“3 Tiek šiuose, tiek kituose darbuose autorè, nors ir ne visada galèdama atsiriboti nuo to meto istorikams primetamų partinių ir ideologinių reikalavimų, remdamasi itin gausia archyvine medžiaga ir kitais šaltiniais, stengèsi išsamiai atskleisti Lietuvos ir Lenkijos konflikto priežastis, eigą ir ypatybes, kartu pagrịsti nuomonę, kad to meto lietuvių nepasitikèjimą Lenkija sukèlè nelanksti, didžiavalstybiné pastarosios vadovų politika Lietuvos atžvilgiu.

Atgavus nepriklausomybę, kai archyvų fondai tapo prieinami, susidomejjimas tarpukario Lietuvos ginkluotosiomis pajègomis, jų modernizavimo ir rengimo valstybès gynybai nuo galimo agresyvaus pietų kaimyno problema susilaukè didžiulio visuomenès ir tyrejjų dèmesio. Per pastarąji nepriklausomos Lietuvos dvidešimtmetị spaudoje pasirodè gana daug didesnès ir mažesnès apimties darbų, kurių autoriai analizuoja ir vertina tuo laikotarpiu vykusius pokyčius ginkluotosiose pajègose, kurių vienas iš pagrindinių uždavinių buvo tinkamai pasirengti gynybiniam karui su agresyviu pietų kaimynu. İ ši darbą ịsitraukè teisininkai, diplomatai,

2 P. Łossowski, Stosunki polsko-litewskie w latach 1921-1939, Wrocław-WarszawaKraków-Gdańsk, 1977.

3 R. Žepkaitè, Diplomatija imperializmo tarnyboje. Lietuvos-Lenkijos santykiai 1919-1939 m., Vilnius, 1980; R. Žepkaitè, Lietuva ir didžiosios valstybès 1918-1940 m., Kaunas, 1986; R. Žepkaitè, Vilniaus istorijos atkarpa 1939-1940 m., Vilnius, 1990. 
istorikai ir periodinè spauda.

Vienas iš pirmųjų tyrèjų, susidomėjusių minèta aptariamojo laikotarpio problema, istorikas A. Kasparavičius, nedidelès apimties straipsnyje trumpai apibūdinęs Lietuvos ir Lenkijos santykius 1926 m., palyginęs abiejų kaimyninių valstybių karinị pajègumą, glaustai nusakè ir Lietuvos karinès vadovybès pastangas pertvarkyti kariuomenę ir padidinti šalies saugumą ${ }^{4}$.

Šis autorius drauge su T. Mieliausku $1998 \mathrm{~m}$. paskelbė spaudoje straipsni „Lietuvos-Lenkijos santykiai ir Lietuvos kariuomenès modernizavimas 1926-1939 metais“. Jau pats straipsnio pavadinimas skaitytojui kelia klausimą: ar įmanoma tokios apimties darbe išsamiai aptarti ir objektyviai ịvertinti sudètingus procesus, ịvykusius per ši gana ilgą laikotarpi? Skaitytojui lieka neaišku, kodèl autoriai, užsibrèžę aptarti šių dviejų kaimyninių valstybių ịtemptus santykius nurodytu laikotarpiu, apsiribojo tik 1926-1927 m. îvykių analize, o vèlesniems ịvykiams apibūdinti nepanaudojo jokių archyvinių dokumentų - apsiribojo viena kita dr. L. Bistro, S. Lozoraičio ir A. Smetonos išsakyta mintimi. Straipsnyje taip pat pernelyg trumpai apžvelgti atskirų ginklų rūšių pokyčiai ir kt. ${ }^{5}$

Lietuvos kariuomenès modernizacija aptariamuoju laikotarpiu domejjosi ir istorikas J. Vaičenonis. Gilindamasis ỉ šią problemą, autorius, dar kartą apžvelgęs K. Škirpos planus, P. Kubiliūno pertvarkymus, gen. S. Raštikio vykdytas reformas ir sausumos pajègose, aviacijoje, karo laivyne ịvykusius pokyčius, nemažai vietos skyrẻ Europos valstybių karinei modernizacijai aptarti 6 .

Vienas iš vèliausiai spaudoje pasirodžiusių tyrimų minèta tematika yra V. Jokubausko straipsnis ${ }^{7}$. Jame autorius, apžvelgęs ankstesnių tyrëjų darbus, ypatingą dėmesị skyrè 1938-1939 m. kariuomenès karinių mobilizacijos planų analizei, remdamasis jų duomenimis nusakè tuometès

4 A. Kasparavičius, Koalicinès liaudininkų ir socialdemokratų vyriausybès pastangos reorganizuoti kariuomenę 1926 metais, Lietuvos istorijos metraštis, Vilnius, 1994, p. 58-63.

5 A. Kasparavičius, T. Mieliauskas, Lietuvos-Lenkijos santykiai ir Lietuvos kariuomenès modernizavimas 1926-1939 metais, Karo archyvas, t. XV, Vilnius, 1998, p. 144-161.

6 J. Vaičenonis, Lietuvos kariuomenès modernizacija (1926-1939), Darbai ir dienos, t. 21, Kaunas, 2000, p. 131-176; J. Vaičenonis, Lietuvos kariuomene valstybès politinio gyvenimo verpetuose (1927-1940), Vilnius, 2004.

7 V. Jokubauskas, Lietuvos kariuomenès kariniai planai ir ištekliai eventualaus karo su Lenkija atveju 1938-1939 m., Karo archyvas, t. XXVI, Vilnius, 2011, p. 272-320. 
Lietuvos finansų ir ūkio mobilizavimo karo atveju perspektyvas, aptarè pačius to meto operacijų planus.

Iš visų čia apžvelgtų tyrimų matyti, jog jų autoriai bene daugiausia dèmesio skyré Lietuvos santykiams su kaimynine Lenkija tarpukario laikotarpio pabaigoje aptarti, taip pat kariuomenès vadovybès gynybos planų ir praktinių veiksmų jiems iggyvendinti analizei. Tačiau panašūs sudètingi procesai, vykę vos pasibaigus Nepriklausomybės kovoms ir užsitęsę iki XX a. ketvirtojo dešimtmečio vidurio, iki šiol dar mažai tirti. Atsižvelgiant $i \mathfrak{i}$ tai, šio straipsnio tikslas ir yra, pasiremus gausia archyvine medžiaga, kurios dauguma ị mokslinę apyvartą ịtraukiama pirmą kartą, periodine spauda, atskirų autorių darbais ir kitais šaltiniais, aptarti Lietuvos kariuomenès gynybos planus ir priemones galimai Lenkijos agresijai 1921-1937 metais atremti.

\section{LIETUVOS KARIUOMENĖS VADOVYBĖS GYNYBOS PLANAI IR VEIKSMAI KRAŠTO VALSTYBINGUMUI APGINTI 1921-1926 METAIS}

\section{Lietuvos kariuomenès vadovybès reakcija ị Lenkijos vadovaujančiųjų sluoksnių agresyvius veiksmus}

Lenkijos vyriausybės prisiimta atsakomybė už gen. L. Želigovskio karinę avantiūrą prieš Lietuvą, paliaubų su ja sutarties Kaune 1920 m. lapkričio 29 d. pasirašymas ir neutraliosios zonos tarp abiejų valstybių kariuomenių nustatymas neužtikrino tolesnių normalių tarpvalstybinių santykių. Užgautos ambicijos dèl gèdingo pralaimejimo lietuviams prie Širvintų ir Giedraičių, nenoras pripažinti tautinio lietuvių atskirumo ir Lietuvos, kaip savarankiškos, nepriklausomos valstybès, funkcionavimo, Tautų Sajungos teikiamos Lenkijai privilegijos skatino to meto valdančiuosius sluoksnius ir toliau neatsisakyti agresyvių tikslų Lietuvos atžvilgiu.

1921 m. pradžioje Lietuvos karinę vadovybę iš kitos neutraliosios zonos pusès pasiekdavo žinios apie tolesnius agresyvius lenkų užmojus - siekị išprovokuoti susirèmimus šioje zonoje, suversti visą kaltę už tai lietuviams ir remiantis šiuo pretekstu mesti prieš Lietuvą gausias ginkluotąsias pajègas. Tuo metu lietuvių fronte nuo Vokietijos iki Latvijos sienos lenkai sutelkè 6 divizijas: I, II ir III legionų, I ir II lietuvių-gudų, 
XVIII pėstininkų ir trijų kavalerijos brigadų dalis ${ }^{8}$.

Lietuvos kariuomeneje $1921 \mathrm{~m}$. pradžioje buvo 4 pèstininkų divizijos, 3 raitelių pulkai, artilerijos brigada, 1 pasienio ir 1 savanorių pulkas, atsargos, mokomasis ir gudų batalionai. Iš viso ginkluotosiose pajègose tarnavo 1175 karininkai, 439 karo valdininkai, 112 karo gydytojų ir 43548 kareiviai9.

Aptariamuoju laikotarpiu Lietuvos ir Lenkijos konfliktas buvo sprendžiamas Tautų Sąjungoje. Konfliktui plečiantis, Tautų Sąjunga turèjo atlikti taikinamąją misiją. Lietuvos visuomenè laukè ir tikejjosi Tautų Sąjungos paramos. Tai plačiai komentavo spauda.

$1921 \mathrm{~m}$. kovo 3 d. Tautų Sąungos Taryba Lenkijai ir Lietuvai pasiūlè tiesiogines derybas. Lenkijai buvo numatyta atsakomybè už būsimus gen. L. Želigovskio veiksmus. Jo kariuomenè turèjo būti sumažinta iki 15000 kareivių, o Lietuvos kariuomenè - pasitraukti ị šalies gilumą ir prie neutraliosios zonos palikti tik 2 divizijas ${ }^{10}$.

Po tokio Tautų Sąjungos nutarimo Lietuva ir Lenkija vèl grịžo prie tiesioginių derybų. Dar joms neprasidejus, Lietuvai buvo daromas spaudimas - daryti nuolaidas Lenkijai ir užmegzti glaudžius tarpvalstybinius santykius. Vienas iš pagrindinių reikalavimų Lietuvai buvo pritarti federacijos su Lenkija idejai. Tiesioginès Lietuvos ir Lenkijos derybos prasidejjo $1921 \mathrm{~m}$. balandžio $20 \mathrm{~d}$. Briuselyje ${ }^{11}$. Jos buvo nevaisingos ir užsitęsè.

Tuo metu Lenkijos karinè vadovybè èmési kariuomenès pergrupavimo, siuntè savo dalinius ị naujas dislokacijos vietas neutraliosios zonos link. Šie lenkų veiksmai dažnai buvo aptariami mūsų kariuomenès vadovybės. Prieita prie išvados, kad lenkai neigiamai vertina Briuselyje vykstančias derybas ir gali artimiausiu metu prieš Lietuvą pradèti agresyvius veiksmus.

Atsižvelgdamas ị Lietuvai gresiantị pavojų, armijos vadas gen. S. Žukauskas $1921 \mathrm{~m}$. balandžio $27 \mathrm{~d}$. išleido labai slaptą direktyvą kariuomenei Nr. 2 ir ịteikè ją asmeniškai visų divizijų vadams ir kitiems aukštiems karininkams; jis ịsakè, kol bus išsiaiškinti galutiniai lenkų siekiai, visoms kariuomenès dalims pasilikti nurodytose vietose, kuriose tuo metu jos

8 Lietuvių armijos vado gen. S. Žukausko 19210427 direktyva kariuomenei Nr. 2, LCVA, f. 929, ap. 3, b. 277, 1. 8.

9 Žinios apie Lietuvos kariuomenès sudètị $1921 \mathrm{~m}$. vasario 1 d., ten pat, b. 292, 1. 13.

10 G. Vilkelis, Lietuvos ir Lenkijos santykiai Tautų Sajungoje, Vilnius, 2006, p. 89.

11 Ten pat, p. 91-92. 
buvo, ir energingai rengtis kovai, tačiau jokiu būdu nepasiduoti lenkų provokaciniams išsišokimams.

Priešui pradejjus puolimą ir iš armijos vado gavus atitinkamą ịsakymą, kovinès parengties divizijos nedelsdamos turèjo įvykdyti šiuos uždavinius:

- IV péstininkų divizija (vadas - plk. K. Ladyga), kurią sudare 10-asis, 11 -asis ir 12-asis pèstininkų pulkai, 4-asis artilerijos pulkas ir 1-ojo raiteliu pulko du eskadronai, palikusi ne daugiau kaip tris batalionus jai pavestai demarkacijos linijai stebèti, su visa artilerija ir kavalerijos eskadronu greitai susitelkti Mauručių-Gudelių-Prienų rajone. Divizijos vadovybè turejo imtis visų priemonių, kad savo rankose išlaikytų tiltą ties Prienais, o kito eskadrono stiprios raitelių užtvaros - stebèti prieigas prie Vilkaviškio, Marijampolès ir Balbieriškio. Divizijos štabas buvo Alytuje.

- III péstininkų divizija (vadas - mjr. I. Musteikis), kurią sudare 3-iasis, 6-asis ir 9-asis pestininku pulkai, 3-iasis artilerijos pulkas ir 1-ojo raiteliu pulko vienas eskadronas, palikusi ne daugiau kaip du batalionus priešo veiksmų sekti, su artilerijos ir kavalerijos eskadronu greitai susitelkti Kaišiadorių rajone ir ginti Kauno miesto tarp Nemuno ir Neries upių prieigas. Divizijos štabas buvo Kaišiadoryse.

- I pesstininkų divizija (vadas - gen. ltn. S. Nastopka), kurios sudètyje buvo 1 -asis, 4 -asis ir 7-asis pestininkų pulkai, 1 -asis artilerijos pulkas ir 3-iojo artilerijos pulko I eskadronas, demarkacijos linijos saugoti palikusi ne daugiau kaip du batalionus, su artilerija ir raitelių eskadronu greitai susitelkti Veprių-Deltuvos-Ukmergès rajone. Divizijos štabas buvo Ukmergeje.

- 2-asis raitelių pulkas (vadas - plk. P. Jackevičius), greitai susitelkęs Kurklių-Kavarsko-Anykščų rajone, gavo užduotị žvalgyti teritoriją Molètų-Utenos ir Kamajų kryptimi. Šiuose rajonuose jis turèjo užmegzti ryšius su I pėstininkų divizija ir pereiti jos vadovybès žinion. Kauno igula (viršininkas - gen. ltn. B. Skomskis; keturi batalionai, dvi baterijos, puse eskadrono) privalèjo būti pasirengusi kovoms ir laukti tolesnių nurodymų Kariuomenès rezervui (vadas - plk. M. Velykis; aštuoni batalionai, trys baterijos ir 1-ojo raitelių pulko I eskadronas) - susitelkti KèdainiųŽeimių-Šètos rajone ${ }^{12}$.

Gavę šią direktyvą, divizijų ir 2-ojo raitelių pulko vadai privalèjo

12 Lietuvių armijos vado gen. S. Žukausko 19210427 direktyva kariuomenei Nr. 2, LCVA, f. 929 , ap. 3, b. 277, 1. 8 . 
tuojau pasiųsti kvartirjerus nurodytų dalinių sutelkimo rajonų nuodugniai ištirti, taip pat nedelsdami parengti karo veiksmų planus, gerai tarpusavyje sutarti, atidžiai stebėti tarp divizijų tarpus.

Paliktoms demarkacijos linijos stebèti dalims nurodyta ị atkaklias kovas su puolančiu priešu neịsitraukti, o tik kiek galint sulaikyti jo pajègas, trukdyti vykdyti žvalgybą ir plačiu frontu trauktis prie savo divizijų sutelkimo linijos. Smulkesnius nurodymus šiuo klausimu privalejjo duoti divizijų ir 2-ojo raitelių pulko vadai. Išsiaiškinus priešo svarbiausio puolimo kryptị, tuoj pereiti $\mathfrak{i}$ kontrpuolimą, dar labiau sutelkti divizijas nurodytuose rajonuose. Komendantūrų dalys, priešui artinantis, turejjo trauktis drauge su artimiausiomis rikiuotès dalimis ir vykdyti jų vadų nurodymus.

Siekiant išvengti galimų didelių nuostolių, armijos vadas įsakè atlikti Ł̇vairių karinių sandèlių ir ịstaigų atsargų evakuaciją iš Kauno ị Šiaulius ir Mažeikius, palikus vietoje tik tai, ko būtinai reikia kariuomenès kovoms. Priešui veržiantis $\mathfrak{i}$ teritorijos gilumą, nurodyta susprogdinti visus geležinkelių ir kitus didelius tiltus, kad jie nepatektų priešui, traukiantis už linijos Kaunas-Jonava-Ukmergè.

Vyriausiasis armijos gydytojas turèjo pristatyti armijos vadui savo sumanymus evakuacijos ir naują sanitarijos įstaigų išdèstymo planą tuo atveju, jei tektų atsitraukti už Nemuno ir Neries upių linijos ${ }^{13}$.

Ši direktyva buvo labai slaptas valstybinès svarbos dokumentas, su jo turiniu buvo supažindinti tik aukštieji karo vadai. Ją pasirašè armijos vadas gen. S. Žukauskas ir l. e. Generalinio štabo viršininko pareigas gen. ltn. M. Katchè. Panašaus turinio ịsakymus pavaldžioms karinėms dalims paskelbè ir visų divizijų vadai.

Nepaisant minètų Lenkijos kariuomenės provokacinių veiksmų, spaudžiant didžiosioms Vakarų valstybėms, derybos turèjo būti tęsiamos. Anglijos, Prancūzijos ir Italijos pasiuntiniai Varšuvoje kartu su Lenkijos užsienio reikalų ministru E. Sapieha apsvarstė Lietuvos ir Lenkijos derybose taikytinus susitarimo principus. Jų sudarytas susitarimo projektas buvo pavadintas „Trijų pasiuntinių projektu“. Jo pagrindinis principas buvo siekti Lietuvos ir Lenkijos federacijos pastarajai palankiausiomis sąlygomis ${ }^{14}$.

Lietuvos delegacija buvo pasirengusi padaryti Lenkijai didelių nuolaidų, tačiau nesutiko sudaryti federacijos, juo labiau - unijos. Ji gegužès

13 Ten pat.

14 R. Žepkaitè, Diplomatija imperializmo tarnyboje..., p. 149. 
14 d. pateikè Lenkijos delegacijai ir derybų pirmininkui P. Himansui memorandumą „Lietuvos teisès ị Vilnių ir jo kraštą“. Jame išdèstytas Lietuvos požiūris i Vilniaus krašto priklausomybès problemą. Lietuvos teisès ł Vilnių ir Vilniaus kraštą buvo pagrịstos istoriniais, teisiniais, etnografiniais ir ūkiniais motyvais ${ }^{15}$. Tačiau derybų organizatoriams lietuvių pasiūlymai pasirodè nepakankami.

1921 m. gegužès 20 d. P. Himansas savo vardu pateikè Lietuvos ir Lenkijos susitarimo projektą. Tačiau šis projektas buvo nepriimtinas ne tik Lietuvai, bet ir Lenkijai. Pagal ji Lietuva turejo tapti federacija ir būti pajungta, o Lenkija - nesitikèti sustiprinti ryšių su Lietuva ir padidinti jai ittaką ${ }^{16}$. Birželio $3 \mathrm{~d}$. Briuselyje derybos laikinai nutrūko.

Tomis dienomis Lietuvos kariuomenès vadovybę pasieké žinios, jog $\mathfrak{i}$ Vilnių iš Lenkijos atsiųsta keletas vagonų civilinių drabužių. Dalis jų sunkiaisiais automobiliais buvo išgabenta Maišiagalos kryptimi. Vilniuje ant kareivių aprangos iki tol buvę „ereliai“ buvo pakeisti vadinamosios „Vidurinès Lietuvos“ specialiais ženklais. Atvežti civiliniai drabužiai buvo skirti lenkų kareiviams ir žandarams, vykdžiusiems išpuolius neutraliojoje zonoje, Širvintų, Giedraičių ir kitose apylinkėse, perrengti.

Remdamasi informacija apie lenkų rengimąsi agresyviems veiksmams prieš Lietuvą, šalies karinė vadovybė $1921 \mathrm{~m}$. gegužès 26 d. paskelbẻ naują visiškai slaptą direktyvą kariuomenei Nr. 4, kurioje pakartotinai nurodè visų keturių pèstininkų ir I raitelių divizijos vadams patikrinti, kaip pasirengta galimoms kovoms, „griežtai laikyti“ neutraliosios zonos liniją ir neįsitraukti $\mathfrak{i}$ aktyvius veiksmus, kuriuos lenkai galètų vertinti kaip lietuvių kariuomenès iššūkį. Buvo įsakyta perimti savo žinion visas jų rajonuose esančias šaulių organizacijas ir užkirsti kelią visokiems savavališkiems jų išsišokimams, neleidžiant $10 \mathrm{~km}$ atstumu nuo neutraliosios linijos vykti jokiems ginkluotų šaulių ir partizanų veiksmams. Už šio ịsakymo nevykdymą ir provokacinius veiksmus šauliams buvo grasinama karo lauko teismu. Karo lauko teismui įsakyta teisti visus civilius, kurie veikia priešo naudai, sugautus ginkluotus, taip pat lenkų kareivius, persirengusius civiliniais rūbais ${ }^{17}$.

15 G. Vilkelis, Lietuvos ir Lenkijos santykiai Tauty Sajungoje, p. 93.

16 R. Žepkaitè, Diplomatija imperializmo tarnyboje..., p. 150-151.

17 Armijos vado gen. S. Žukausko ir Generalinio štabo viršininko gen. ltn. M. Katchès 19210526 visai slapta kariuomenei direktyva Nr. 4, LCVA, f. 929, ap. 3, b. 277, 1. 53. 
Padètis pietinio kaimyno pasienyje èmė smarkiai komplikuotis: kūrèsi daug karinių lenkų organizacijų, aktyvejjo jų partizanų veikla, buvo dažni Lietuvos sargybų ir gyventojų užpuldinèjimai. Partizanų organizavimo darbas buvo patikètas iš kariuomenés paleistiems lenkų karininkams ir kareiviams. Buvo rengiami ginklų sandèliai, miškuose vyko slapti partizanų mokymai.

Šiuo sudètingu laikotarpiu pasikeite Lietuvos kariuomenès vadovybè. Atsistatydinus armijos vadui gen. S. Žukauskui, $1921 \mathrm{~m}$. gegužès $29 \mathrm{~d}$. laikinai šias pareigas perèmé Oro laivyno vadas gen. ltn. J. Kraucevičius ${ }^{18}$. Šie pokyčiai sutapo su Tautų Sajungos nutarimu birželio $28 \mathrm{~d}$. atnaujinti derybas Ženevoje. Vèl prasidejjo didžiųjų šalių spaudimas tiek Lietuvai, tiek Lenkijai. Buvo pateiktas antrasis P. Himanso pasiūlytas variantas. Jis netiko nei Lenkijai, nei Lietuvai. Taip baigèsi dar vienas Tautų Sąjungos mėginimas užgesinti Lietuvos ir Lenkijos nesantaiką.

Tuo metu Lenkijos karinè vadovybe Vilniaus krašte sutelke dideles karines pajegas. Gautomis žiniomis, nustatyta, jog lietuvių fronte veikè II lenkų armija, kurios štabas buvo Lydoje. Pasirèmę sukaupta medžiaga ir ją apibendrinę, gen. ltn. J. Kraucevičius ir Generalinio štabo viršininkas gen. ltn. M. Katchè 1921 m. gruodžio 8 d. kariuomenei paskelbè visiškai slaptą direktyvą Nr. 9. Minètos lenkų armijos sudètyje buvo penkios pèstininkų divizijos su joms priklausančia pèstija, artilerija ir kavalerija, kurios buvo itin daug ir kuri bazavosi Suvalkų, Gardino, Vilniaus miestuose ir aplinkiniuose rajonuose. Iš viso lietuvių fronte tuo metu buvo sutelkti 53 pèstininkų batalionai, 40 kavalerijos eskadronų, 183 patrankos ${ }^{19}$.

Lietuvos kariuomenès vadovybei buvo sunku nuspeti tikruosius priešo sumanymus, bet neliko abejoniu, kad iš jo nieko gero negalima laukti. Tiketasi, kad aktyvūs priešo veiksmai prasidès jau žiemą, dar didesnè tikimybè - $1922 \mathrm{~m}$. pavasarị. Reikèjo atsižvelgti ị tai, kad tuo metu tektų kovoti ne vien su gen. L. Želigovskio pajègomis, bet ir su visa kitų užduočių neturinčia lenkų kariuomene. Tikètasi, kad karo veiksmai galètų prasidèti Suvalkijoje, kur lenkai iš pradžių užimtų geležinkelio liniją

${ }^{18}$ Krašto apsaugos ministro J. Šimkaus 19210529 i̇sakymas kariuomenei Nr. $125 \$ 1$ ir tụ pat metų gegužès 30 d. ịsakymas kariuomenei Nr. $127 \$ 1, L C V A$, f. 384, ap. 1, b. 37, 1. 167-168.

${ }^{19}$ L. e. kariuomenès vado pareigas gen. Itn. J. Kraucevičiaus ir Generalinio štabo viršininko gen. ltn. M. Katchės 19211208 visiškai slapta direktyva kariuomenei Nr. 9, LCVA, f. 510 , ap. 1, b. 26, 1.3 . 
Alytus-Šeštokai, o po to nutrauktų Lietuvos kariuomenès susisiekimą geležinkeliu Kaunas-Virbalis.

Numatęs tokias galimybes, 1. e. kariuomenès vado pareigas gen. ltn. J. Kraucevičius ịsakè Lietuvos kariuomenei visapusiškai ir energingai rengtis kovai, kartu būti ramiems ir jokiu būdu nepasiduoti galimoms lenkų provokacijoms. Minètoje direktyvoje buvo pabrēžiama, jog, ìvykus lenkų puolimui, „mes neturime nieko gailèti beginant mūsų garbę ir nepriklausomybę, bet tuo pačiu privalome veikti taip, kad neduoti priešininkui galimybès daug gausesnèms jègoms igyti pigių pergalių “20.

Prasidejjus priešo puolimui, gavusios kariuomenès vado įsakymą karinès dalys turèjo neatidèliodamos vykdyti šiuos uždavinius:

- IV pèstininkų divizija (vadas - plk. ltn. K. Žukas), kurią sudarè šeši batalionai, keturios artilerijos baterijos, 2-ojo kavalerijos pulko vienas eskadronas ir pionierių būrys, palikusi du batalionus stebèti demarkacijos linijos nuo Vokietijos sienos ties Vištyčio ežeru iki Jakẻnų kaimo išskirtinai, turejo susitelkti Gotlibiškių rajone, kavalerijai žvalgant Pilviškių, Marijampolès ir Balbieriškio kryptimi. Kilus pavojui, divizijos dalių užduotis - atkakliai ginti Kauno prieigas, užėmus senąsias rusų ir vokiečių pozicijas Mironiškis-Janučiai, Rožučiai-Pakalniškis.

- III péstininkų divizija (vadas - plk. ltn. I. Musteikis), kurią sudarè devyni batalionai, gudų batalionas, keturios artilerijos baterijos, 2-ojo kavalerijos pulko vienas eskadronas, pionierių būrys, vienas šarvuotas automobilis ir minosvaidžių kuopa, palikusi du batalionus demarkacijos linijos ties Jakènais iki Valiukiškių kaimo imtinai stebėti, turèjo susitekti Kaišiadorių rajone. Divizijos dalims nurodyta ginti teritoriją tarp Nemuno ir Neries upių Bartkūnų-Miežionių-Gegužinès linijoje. Gynybos tikslas - vilkinamaisiais veiksmais sulaikyti priešininką kuo ilgiau, kad divizija nerizikuotų būti sumušta. Atsitraukus nuo šios linijos, vienam pulkui ir artilerijos baterijai dengti Jonavą, užèmus Spanėnų-BajoriškiųMeištonių pozicijas kairiajame Neries upès krante. Visoms kitoms divizijos pajègoms ịsakyta ginti Kauną senojoje rusų ir vokiečių VieškūnųAmalių-Biruliškių-Narepų pozicijoje, gudų batalionui - kuo greičiau vykti i vietą, užimti, saugoti ir ginti dešinịji Neries krantą tarp Narepų ir Spanènų. Jei yra galimybè, batalionas turi būti palaikomas artilerijos ugnimi.

20 Ten pat, 1. 4-6. 
- I pėstininkų divizija (vadas - plk. K. Kleščinskas), kurią sudarè devyni batalionai, trys artilerijos baterijos, 2-ojo kavalerijos pulko vienas batalionas, du šarvuoti automobiliai ir vienas pionierių būrys, palikusi tris batalionus demarkacijos linijos nuo Valiukiškių kaimo iki sienos su Latvija ties Kurzumo dvaru imtinai stebėti, su artilerija turèjo sudaryti grupę Veprių-Deltuvos-Ukmergès rajone ir išnaudoti galimybes pereiti i kontrpuolimą. Šiam tikslui pasiekti reikejjo būtinai išlaikyti savo rankose perkèlas per Šventosios upę ties Ukmerge.

- Kariuomenès atsarga: II péstininkų divizija (vadas plk. ltn. M. Velykis), kurią sudarè devyni batalionai, trys artilerijos baterijos ir vienas pionierių būrys, palikusi Panevèžyje vieną batalioną su šauliais gynybai organizuoti, priešo kavalerijai arba partizanams prasiveržus kairiajame sparne, privalejo kuo greičiau susitelkti Kẻdainių-Žeimių rajone ir pasirengti manevriniams veiksmams.

- I kavalerijos divizija (vadas - gen. ltn. B. Skomskis), kurią sudarè 1-ojo kavalerijos pulko keturi eskadronai ir 3-iojo kavalerijos pulko trys eskadronai, palikusi Kauno iguloje mokomąji ir vieną 2-ojo kavalerijos pulko eskadroną, turejjo kuo skubiau perduoti 2-ojo kavalerijos pulko po vieną eskadroną IV, III ir I pėstininkų divizijoms.

- Kauno igula, ł̇ kurios sudèti ịejo Karo mokykla, Mokomasis batalionas, Atsargos batalionas, Kauno komendantūros kuopos, šarvuotụjų traukinių pulkas, du šarvuoti automobiliai, vienas mokomasis eskadronas, 2-ojo kavalerijos pulko vienas eskadronas ir $12 / 3$ pionierių kuopos, turejo būti pasirengusi vietose ir laukti nurodymų.

Tarp divizijų buvo nustatytos skiriamosios linijos:

1. tarp IV ir III péstininkų divizijų - Lyda-Rodūnè-Jakènai-Punia (šie punktai buvo priskirti III pèst. divizijai, toliau Nemuno upe iki Vilkijos - IV pèst. divizijai);

2. tarp III ir I pėstininkų divizijų - Vilnius-Neries upé-geležinkelis Jonava-Kèdainiai buvo priskirti III pèst. divizijai;

3. tarp I pèstininkų ir I kavalerijos divizijų - Pabradè-Giedraičiai-Želva-Žemaitkiemis-Taujènai, toliau - vieškeliu Raguva-Panevėžys, dar toliau - geležinkeliu Panevėžys-Šeduva. Visi minèti punktai ir geležinkelis buvo priskirti I pèst. divizijai. Ši skiriamoji linija turejjo įsigalioti I pėst. divizijai pradejus vykdyti minètos direktyvos III skyriaus nurodymus. Geležinkeliais įvairiems kroviniams vežti galejjo naudotis visos divizijos. 
Gavę šią direktyvą, pėstininkų ir kavalerijos divizijų vadai privalèjo tuojau pasiųsti ị vietas savo karininkus rekognoskuotès atlikti. Be to, kiekviena divizija turejjo tiksliai išžvalgyti bent po du kelius užnugaryje nuo susitelkimo rajono tarp skiriamųjų linijų iki Nevėžio upès. Visais atvejais, kai ị susitelkimo vietą buvo galima nuvykti tiek geležinkeliais, tiek atžygiuoti, nurodyta parengti atskirus sumanymus, taip pat neatideliojant teikti žinias susisiekimo viršininkui, kiek reikès ešelonų.

Divizijų vadai turejo nedelsdami apgalvoti ir parengti smulkius savo veiksmų planus, atsižvelgdami ị kariuomenès vado sumanymus ir nurodymus:

a) vykstančios ị nurodytus susitelkimo rajonus divizijos turejjo tarp savęs palaikyti ryši ir atidžiai stebėti tarpus tarp padalinių. Visoms dalims ịsakyta telktis tokiu būdu, kad nebūtų per anksti ịtrauktos ị kautynes ir išsaugotų veiksmų laisvę. Ši reikalavimą ịvykdyti buvo itin svarbu;

b) paliktoms demarkacijos linijos stebèti kariuomenès dalims buvo nurodyta neįsitraukti ị atkaklią kovą su puolančiu priešu, o kiek galint stabdant jo pajègas ir žlugdant sumanymus, žvalgant, plačiu frontu trauktis prie savo divizijų sutelkimo linijos. Smulkius nurodymus šiuo klausimu privalèjo parengti divizijų vadai.

I péstininkų divizijos dalims, kurios atsitraukdamos nuo demarkacijos linijos kairiojo sparno negalejo prisijungti prie savo divizijos, nurodyta jungtis prie artimiausių kavalerijos dalių ir padeti joms vykdyti užduotis. Dèl to turejo tarpusavyje susitarti I pėstininkų ir I kavalerijos divizijų vadai.

Išsiaiškinus priešininko svarbiausio puolimo kryptị, kariuomenès vado nuomone, IV ir III péstininkų divizijos privalès pereiti $\mathfrak{i}$ kontrpuolimą, todèl iki tol dar labiau reikia sutelkti divizijas nurodytuose rajonuose. Komendantūrų dalys, priešininkui artinantis, turèjo trauktis su artimiausiais pulkais ir veikti pagal tų pulkų vadų nurodymus.

Atitinkami uždaviniai buvo iškelti ir karo aviacijai. Jos viršininkui įsakyta parengti veiksmų karui prasidejus sumanymus. Visų pirma ji žvalgydama turèjo surinkti kuo daugiau žinių apie priešininko sumanymus, aktyviai prisidèti darant jam kuo daugiau nuostolių užnugaryje, nutraukti susisiekimą geležinkeliais tarp Vilniaus ir Gardino iš vienos pusès, Molodečno ir Lydos - iš kitos.

Atsakingos užduotys buvo skirtos karo technikos viršininkui. Jis turèjo 
užtikrinti ir ištobulinti Generalinio štabo ryšius su divizijomis jų susitelkimo vietose, kad, karo veiksmams prasidejus, šis štabas galètų prireikus iš Kauno persikelti ị Kèdainius. Jo pareiga buvo keltus per Nemuną ties Jurbarku, Skirsnemune, Seredžiumi, Rumšiškèmis ir Darsūniškiu pavasarị apsaugoti nuo potvynių ir ledlaužių. Be to, pastatyti du keltus tarp Kauno ir Pakalniškių, per Nerị - tris keltus tarp Kauno ir Narepų ir du keltus ties Dranseikiais. Kariuomenè turèjo būti gerai supažindinta su keltų vietomis. Turèjo būti gerai apskaičiuotas susisiekimo priemonių skaičius ir jos parengtos evakuoti iš Kauno.

Pareikalauta kuo greičiausiai pasirengti sugadinti visus pagrindinius geležinkelių ir kitus svarbesnius tiltus ì pietus nuo Nemuno-NeriesŠventosios linijos. Taip pat nurodyta imtis visų priemonių, kad geležinkelio ruožu Šeštokai-Varẻna negalètų pravažiuoti nei iš vienos, nei iš kitos pusès joks šarvuotas ar kitoks priešininko traukinys. İvkus antpuoliui, minètas ruožas turejjo būti visiškai sugadintas, taip pat sunaikinti visi ten buvę garvežiai ir vagonai.

Tiltus ir kitas susisiekimo priemones (įskaitant oro linijas), buvusias ne toliau kaip $30 \mathrm{~km}$ nuo demarkacijos linijos, sunaikinti buvo patikèta divizijų vadams, tolimesnius tiltus ir susisiekimo priemones jie galejo naikinti tik gavę Generalinio štabo sutikimą.

Nelaukiant priešo puolimo reikèjo:

1. Energingai tęsti evakuaciją iš Kauno ị Viekšnių-Šiaulių-Tauragès ruožą ìvairių karo sandèlių ir atsargų, paliekant Kaune tik tai, kas būtiniausia einamajam aprūpinimui kariuomenès kovos priemonemis ir maisto produktais užtikrinti. Vykdant šį nurodymą reikejjo dèti visas pastangas, kad dauguma evakuojamo turto patektų í Lyduvènų-Tauragès ruožo rajoną, tačiau Batakių stotị ir Skaudvilès miestelị palikti laisvus.

2. Tiekimo organams, susitarus su divizijų vadais, parengti iš anksto evakuacijai ị užnugarị pafrontès sandèlius ir ịstaigas.

3. Tiems patiems tiekimo organams, susitarus su divizijų vadais, užtikrinti tvarkingą tiekimą tuo atveju, jei kariuomenè susitelktų nurodytuose susitelkimo rajonuose.

4. Karo sanitarijos viršininkui nedelsiant ịkurdinti ne mažiau kaip dvi ligonines ị vakarus nuo Nevèžio upès ir nurodyti kiekvienai divizijai, i kurią ligoninę ir kokiu būdu evakuoti savo sužeistuosius ir ligonius kautynèms prasidejjus. 
Kad nebūtų pasiduota lenkų provokacijoms bandant lietuvius įtraukti ¡ karą, kariuomenès vadas įsakè:

1. Jokiu būdu neperžengti demarkacijos linijos.

2. Griežtai sekti ir $10 \mathrm{~km}$ atstumu nuo demarkacijos linijos neleisti mūsų šauliams ir partizanams vykdyti jokių ginkluotų veiksmų, kol nèra atviro karo.

3. Visus civilius, veikiančius priešininko naudai ir sugautus ginkluotus, teisti karo lauko teisme. Taip elgtis ir su visais lenkų kareiviais, jei jie būtų sugauti persirengę civiliniais drabužiais.

4. İsiveržusias ị mūsų teritoriją lenkų, persirengusių civiliniais drabužiais, bandas, nors ir palaikomas Lenkijos kariuomenès, naikinti vejant, neleidžiant peržengti demarkacijos linijos be tam tikro kariuomenès vado ịsakymo.

Kiekvienas operatyviniu požiūriu tiesiogiai pavaldus kariuomenès vadui dalies vadas ar ịstaigos viršininkas ne vèliau kaip per 8 dienas turèjo pristatyti savo detalius sumanymus ir parengtų įsakymų nuorašus, o ne vèliau kaip per 14 dienų atliktų rekognoskuočių - žvalgybos - rezultatus.

Ši direktyva buvo didžiausia valstybės paslaptis. Ji pakeitė visas anksčiau paskelbtas direktyvas. Su šio dokumento turiniu buvo supažindinti tiktai divizijų vadai. Kiti vadai ir viršininkai su ja galèjo susipažinti tik tiek, kiek tai buvo būtina jų užduotims ir suderintiems su kaimynais ir atitinkamomis įstaigomis veiksmams atlikti. Gavus direktyvą, reikejjo iš karto telegrafuoti asmeniškai kariuomenès vadui, o po to jos perdavejui grąžinti, taip pat asmeniškai Generalinio štabo viršininkui, visas anksčiau skelbtas direktyvas (1-8 imtinai) ${ }^{21}$.

Kaip matyti, ši direktyva buvo visa apimanti, gerai apgalvota, kruopščiai parengta. Joje aiškiai buvo nurodytos visų kariuomenès dalių ir karinių ịstaigų veiklos kryptys lemtingu galimos lenkų agresijos prieš Lietuvą atveju.

Nors minètu laikotarpiu lenkų puolimas ir neịvyko, padètis Lietuvos pašonèje visą laiką buvo įtempta. Iš karinès žvalgybos agentų, perbejgèlių ir neutraliosios zonos gyventojų pranešimų buvo žinoma, jog lenkų karinè vadovybė ị Vilniaus kraštą siunčia vis naujus karinius dalinius, juos pergrupuoja netoli neutraliosios zonos, inspektuoja, organizuoja ịvairias provokacijas ir pan., t. y. toliau rengiasi agresyviems veiksmams.

${ }^{21}$ Ten pat, 1. 4-6. 


\section{Vyriausybės priemonės ginkluotųjų pajègų skaičiui mažinti}

$1922 \mathrm{~m}$. sausio pradžioje Lietuvos kariuomeneje buvo 1223 karininkai, 462 karo valdininkai, 104 karo gydytojai, 20 kunigu ir 48049 kareiviai $^{22}$. Tais metais Krašto apsaugos ministerijai buvo skirta 1839723960 auksinų, kas sudarè 42,60 proc. visų tiems metams skirtų lešų ${ }^{23}$.

Atsižvelgiant $\mathfrak{i}$ tai, kad taikos sąlygomis tokị didelị karių skaičių išlaikyti valstybès iždui buvo sunkiai pakeliama našta, šalies vyriausybė, nors ir gerai suprasdama agresyviai nusiteikusios kaimyninès Lenkijos pavojų, buvo priversta mažinti savo ginkluotąsias pajègas. Dar $1921 \mathrm{~m}$. gruodžio mènesị ịvykusiame viename iš Karo Tarybos posèdžių krašto apsaugos ministras prof. J. Šimkus buvo supažindintas su vyriausybès nutarimu sumažinti krašto ginkluotąsias pajègas iki 35000 žmonių ir tai atlikti ne vèliau kaip iki $1922 \mathrm{~m}$. sausio mènesio pradžios ${ }^{24}$. Šis nutarimas buvo priimtas gana skubotai, visiškai neatsiklausus aukštesniosios karo vadovybès nuomonès. Ji apsvarsčiusi, pastaroji prièjo prie išvados, jog taip elgdamasi vyriausybè supranta numatomos priemonès galimus neigiamus padarinius ir nereikalaus karo vadovybès atsakomybès.

Laikinai einantis kariuomenès vado pareigas gen. ltn. J. Kraucevičius ir Generalinio štabo viršininkas gen. ltn. M. Katchè, ịvertinę susidariusios padèties rimtumą ir jausdami savo pareigą, $1921 \mathrm{~m}$. gruodžio $13 \mathrm{~d}$. raštu kreipèsi ị krašto apsaugos ministrą (rašto nuorašą nusiuntė ir Ministrui Pirmininkui), kuriame išdèstė savo samprotavimus dèl minèto nutarimo padarinių galimos lenkų agresijos atveju. Jų teigimu, $1922 \mathrm{~m}$. sausio ménesị atleidus iš kariuomenès per 20000 žmonių, ji netektų daug patyrusių puskarininkių, specialistų ir bendrai geriausiai išmokytų ir parengtụ kovoms karių, todèl taptų nelabai tinkama kautynèms. Jų nuomone, ši priemonè būtu leistina tik tuo atveju, jei reforma vyktų ne numatytus 1-2, o mažiausiai 4-5 mènesius, t. y. laikotarpí, per kurị būtų galimybė parengti, kad ir silpnus, puskarininkius, o pašauktus naujokus spèti šiek

${ }^{22}$ Kariuomenès sudèties žinios, 192201 01, LCVA, f. 384, ap. 1, b. 328, 1. 74.

${ }^{23}$ V. Lesčius, Lietuvos kariuomenès aprūpinimas (1921-1940), Karo archyvas, t. XXVI, Vilnius, 2011, p. 162.

${ }^{24}$ L. e. kariuomenès vado pareigas gen. ltn. J. Kraucevičiaus ir Generalinio štabo viršininko gen. ltn. M. Katchès 19211213 slaptas asmeninis raštas Nr. 1927 krašto apsaugos ministrui (nuorašas - Ministrui Pirmininkui), LCVA, f. 929, ap. 3, b. 291, 1. 165-166. 
tiek apmokyti to meto karo sąlygomis.

Kariuomenès vadovybès teigimu, viltis, karo veiksmams prasidejus, suspèti pašaukti ị kariuomenę atsarginius arba paleistus neribotų atostogụ būtų neturẻjusi realaus pagrindo. Ir taip nedidelè mūsų kariuomené, dar susilpninta iš jos paleidus geriausias pajegas, iškart būtų buvusi priversta atiduoti gausesnèms priešininko pajègoms žymią Lietuvos teritorijos dalị ir iš jos jokių papildymų nebegalètų gauti. Kariuomenès papildymas žmonėmis iš likusių apskričių, jų rūšiavimas pagal kategorijas ir galop pristatymas ị kariuomenès dalis būtų labai sunki operacija, nes jai sèkmingai atlikti, turint toli gražu dar netobulą mobilizacijos vykdymo aparatą, būtų atsiradę daug kliūčių ir reikejję ne mažiau kaip 8-10 dienų. Kartu labai abejotina, ar tiek laiko pajègos turètų, kadangi karo veiksmai greičiausiai prasidètų mums netikètai ir visa priešo akivaizdoje esanti kariuomenè iškart ištisai būtų ịtraukta ị kautynes. Tokiomis aplinkybèmis, spaudžiant priešininkui, normali mobilizacija ir perejjimas iš taikos ị karo padètị vargu ar būtų užtikrintas ${ }^{25}$.

Pažymėtina, kad tuometė kariuomenès vadovybė gerai suprato, kokia nepaprastai sunki finansinė našta siekiant išlaikyti savo pajègas gula ant Lietuvos gyventojų pečių. Tačiau tuo metu krašte buvo sprendžiamas klausimas: būti ar nebūti? Kartu visi laikèsi nuomonès, jog, vienaip ar kitaip, reikia rasti lèšų kariuomenei, kuri garantuotų jos būtị, išlaikyti. Kariuomenès vadovybès teigimu, laikyti demobilizuotą kariuomenę, esant neaiškiai politinei padéčiai, gali tik tos valstybės, kurių didelè teritorija. Tačiau ir jos, rengdamosi karui, turètų sustiprinti savo ginkluotąsias pajègas.

Atsižvelgdama ị visas čia išvardytas aplinkybes, kariuomenès vadovybė prièjo prie išvados, jog šalies padètis neleidžia imtis priemonių, kurios prilygtų nusiginklavimui matant priešiškai nusistačiusio kaimyno, jau ne kartą apgavusio, elgesị. Esant itin sunkiai finansinei padéčiai ir negalint išlaikyti iki tol buvusio karių skaičiaus, ji pasiūlè vyriausybei kariuomenę mažinti pamažu, labai atsargiai, neardant negausių pajègų, kurios liks po demobilizacijos ${ }^{26}$.

Tačiau ị šiuos kariuomenès vadovybès pateiktus argumentus vyriausybè atsižvelgè tik iš dalies. $1922 \mathrm{~m}$. sausio mėnesị jos sprendimu iš kariuomenès atostogų neribotam laikui buvo paleista 11617 vyrų, gimusių

25 Ten pat.

26 Ten pat. 
1896-1900 metais ${ }^{27}$.

Krašte esant sudètingai padèčiai, $1922 \mathrm{~m}$. pradžioje atsistatydinus vyriausybès vadovui K. Griniui, o kartu ir krašto apsaugos ministrui prof. J. Šimkui, naujuoju Krašto apsaugos ministerijos vadovu vasario $2 \mathrm{~d}$. buvo paskirtas vyr. inžinierius B. Sližys ${ }^{28}$. Iš kariuomenès vado pareigų pasitraukè ir jas laikinai ejjęs gen. ltn. J. Kraucevičius. Nuo tų metų vasario $11 \mathrm{~d}$. kariuomenès vado pareigas pradejo eiti plk. J. Stanaitis ${ }^{29}$.

Vyriausybės krizè ir pagrindinių vadų kaita buvo plačiai aptariama to meto visuomenès, ìvairių politinių partijų (ypač kairiųjų) spaudoje, kariuomenejje, ypač karininkų. Kairiosios partijos aštriai kèlè klausimą dèl karo padèties panaikinimo, karo komendantų galių mažinimo ir kt. ${ }^{30}$ Buvo siūlymų atšaukti karo padètị vienose apskrityse ir palikti galioti ją kitose.

Reaguodamas ị tai, Generalinio štabo viršininkas gen. ltn. M. Katchẻ slaptame raporte krašto apsaugos ministrui mjr. inž. B. Sližiui tvirtino, jog ir esant karo padèčiai dèl nepakankamai energingo ir ne visur nuoseklaus jos reikalavimų taikymo antivalstybiniai elementai veikia gana laisvai. Jis teige, jog jei kai kuriose apskrityse karo padètis bus atšaukta, daug elementų, kuriems nepatinka Lietuvos nepriklausomybė arba tikrai demokratiška Lietuva, iš karto savo veiklos centrą perkels į tas apskritis, kuriose yra palankios sąlygos šių organizacijų veiklai plètoti, taip pat ir $\mathfrak{i}$ kaimynines apskritis, kur galioja karo padetis. Gen. ltn. M. Katché teigé, jei vis dèlto būtų nutarta karo padètị atšaukti, kad ji būtinai turètų būti laikinai palikta: 1) kariuomenejje, 2) geležinkeliuose ir 3) pafrontès zonoje ${ }^{31}$.

Gen. ltn. M. Katchès nuomone, karo padètis kariuomenèje ir karo ìstaigose turi būti palikta galioti visur, kur tik jos yra ịkurtos. Dar daugiau - ji turi būti visose kariuomenės žinioje esančiose vietovėse, kur kariai įsipainioja ị ịvairius nusikaltimus. Antivalstybiniai elementai puikiai suprato, jog, kol kariuomenė bus ištikima valdžiai, visos jų pastangos

27 KAM Mobilizacijos skyriaus viršininko mjr. A. Zubrio 19220202 visiškai slaptos žinios apie išleistus neribotam laikui atostogų vyrus, gimusius 1896-1900 m., LCVA, f. 929, ap. 1 , b. $82,1.3$.

2819220204 iqsakymas kariuomenei Nr. $35 \$ 1, L C V A$, f. 384, ap. 1, b. 41, 1. 68.

29 Krašto apsaugos ministro 19220211 ịsakymas kariuomenei Nr. 46a, ten pat, 1. 80.

30 Plačiau šiuo klausimu žr.: M. Kuodys, Karo padeties klausimas Lietuvos seimuose (1919-1927), Karo archyvas, t. XXII, Vilnius, 2007, p. 219-290.

31 Generalinio štabo viršininko gen. ltn. M. Katchès 19220326 slaptas raportas Nr. 316 krašto apsaugos ministrui, LCVA, f. 929, ap. 3, b. 354, 1. 17. 
nueis perniek, todèl visokiais būdais pirmiausia stengèsi susilpninti kariuomenès drausmę ir kovos dvasią. Lietuvos kariuomenė tuo metu buvo dar labai jauna. Joje buvo daug didelių trūkumų: silpni ir nepatyrę kadrai, tradicijų stoka, prastas aprūpinimas. Stokota drabužių, avalynės, uniformų, ginklų, kareivinių, maisto. Varginga buvo ir karininkų materialinė padètis. Dèl to suaktyvèjo kraštutinių politinių organizacijų agitacija.

Gen. ltn. M. Katchè teigè, jog kariuomenès organizacija, jos gyvavimas ir veikla labai susiję su sklandžiu geležinkelių aparato darbu. Jị labai neigiamai paveikè ir vadinamoji geležinkelių demilitarizacija. Todèl karo padètis geležinkeliuose, jo nuomone, turèjo likti.

Karo padetị siūlyta palikti galioti ir pafrontès zonoje, kur pirmiausia galèjo prasidèti priešininko puolimas. Esant užpuolimo pavojui, neišvengiamai reikalingas frontas ir pafrontès ruožas, ir čia karinè vadovybė turejo naudotis visomis savo teisemis. Todèl buvo teigiama, kad tuo metu nustatytas $30 \mathrm{~km}$ šios zonos plotas nepakankamas ir ji reikia padidinti mažiausiai iki $50 \mathrm{~km}^{32}$.

Tuo metu naujuoju vyriausybės vadovu tapęs E. Galvanauskas toliau vykdè kariuomenès mažinimo politiką, siekdamas ją sumažinti iki taikos metu reikalingo karių skaičiaus. $1922 \mathrm{~m}$. gegužès $6 \mathrm{~d}$. iš ministro pirmininko pavaduotojo, teisingumo ministro, krašto apsaugos, užsienio reikalų ir finansų, prekybos ir pramonès ministrų buvo sudarytas ministrų kabinetas kariuomenès mažinimo klausimams svarstyti ${ }^{33}$.

Dar šiek tiek anksčiau, sužinojęs apie vyriausybès nusistatymą toliau mažinti kariuomenę, Generalinio štabo viršininkas gen. ltn. M. Katchẻ $1922 \mathrm{~m}$. balandžio $24 \mathrm{~d}$. visiškai slaptame operatyviniame raporte vadovybei išdėstè savo požiūrị ir pateike jai argumentuotus pasiūlymus minètu klausimu. Pagal to meto etatus kariuomenèje iš viso turèjo būti 2045 karininkai, 735 karo valdininkai, 58840 kareivių, 12745 arkliai. Jo nuomone, nepriklausomybei apginti mažiausiai tiek reikètų karių, esant tokiai politinei padéčiai, kai, viena vertus, nèra nè vieno sąjungininko arba bent patikimo draugo ir, kita vertus, turint stiprius kaimynus: labai abejotiną „draugą“ Rytuose, nesutaikomą priešininką Pietuose ir ilgą visai atvirą sausumos sieną Vakaruose. Tokiu atveju, kilus karui, reikia būti

\footnotetext{
32 Ten pat.

33 Ministrų kabineto reikalų vedèjo 19220506 visiškai slaptas raštas Nr. 80 krašto apsaugos ministrui, LCVA, f. 384, ap. 2, b. 337, 1. 10.
} 
pasiruošus kiek įmanoma įtempti visas jègas, norint iš tikrụjų apginti savo nepriklausomą valstybę.

Gen. ltn. M. Katchẻs nuomone, šalyje iš tikrųjų nieko nebuvo padaryta nepriklausomybei apginti: iki tol vykdytų demobilizacijų metu kariuomenė gerokai sumažejo ir nebeatitiko to meto etatų reikalavimų. Tokio neleistino reiškinio priežastys buvo labai ịvairios ir paaiškinamos ne vien lëšų stoka. Tam turëjo ịtakos ir plačiųjų visuomenès sluoksnių neatsakingas požiūris ị valstybingumo išsaugojimą. Jis teigè, kad tokia padètis galètų būti pateisinama tik tuo atveju, jei vadovybei pavyktų sèkmingai išspręsti su kaimynais visus ginčytinus klausimus, pasirašant palankias konvencijas taip pat ir su tais, su kuriais nėra kilę jokių ginčų, arba jei kokia nors reali tarptautinè jèga garantuotų mūsų neliečiamybę ${ }^{34}$.

Gen. ltn. M. Katchès teigimu, jeigu vyriausybè vèl iškèlè klausimą dèl Lietuvos ginkluotụjų pajègų tolesnio mažinimo ir jei iš tikrụjų ši priemonė yra tokia svarbi ir neišvengiama, pirmiausia būtina aiškiai suprasti tą didelị pavojų, kuris tokiu atveju gresia, o po to kariuomenę mažinti kuo atsargiausiai, planingai ir sistemingai, vadovaujantis šiais pagrindiniais samprotavimais:

1. Mobilizacija (kariuomenès dalių perèjimas iš taikos meto padèties $\mathfrak{i}$ karo padètį ir naujų dalių formavimas) būtinai turès būti vykdoma tokioje srityje, kuriai negrès priešininko ịtaka ir spaudimas. Vadinasi, reikètų imtis visų priemonių, kad priešininkas prie mobilizacijos rajono negalètų prieiti anksčiau negu ji bus baigta ir mobilizuota kariuomenè visiškai pasirengs kovos veiksmams. Todèl pasienio zonose jau taikos metu kariuomenè turejo būti suformuota pagal karo meto etatus. Toliau nuo valstybės sienos esančios dalys galèjo būti sumažintos sudèties, turint omenyje tai, kad jos prireikus taip pat būtu atitinkamai sukomplektuotos.

Gen. Itn. M. Katché primine, kad Lietuva dèl mažos teritorijos mobilizacijos atveju visa taptų pasienio zona. Tiktai iš keturių galimų priešininkų išrinkus du tikriausius (iš pietų ir rytų!), galima nustatyti mobilizacijai daugmaž patogų rajoną - placdarmą. Toks placdarmas būtų Žemaitija, kurios ribas iš pietų apibrèžia Nemuno, iš rytų - Nevéžio upès. Tas pats placdarmas turètų tapti lemiamos kovos arena, jei šalies

${ }^{34}$ Generalinio štabo viršininko gen. ltn. M. Katchès 19220424 visiškai slaptas raportas Nr. 445 apie vyriausybès nusistatymą dèl kariuomenès sudèties sumažinimo, LCVA, f. 929 , ap. 3, b. $354,1.27$. 
kariuomenei, stipresnio priešininko spaudžiamai, tektų pasitraukti iš kitu Lietuvos teritorijų.

2. Šiame placdarme jau taikos metu turètų būti sutelktos visos arkliu pašaro, ginklų, aprangos ir maisto atsargos, reikalingos žmonèms, kurie, paskelbus mobilizaciją, privalëjo čia susirinkti, aprūpinti, taip pat, kaip pačiame nepavojingiausiame ruože, iš anksto ịrengtos pagrindinès kariuomenès parduotuvès („magazinai“), sandèliai, dirbtuvès, rūsiai, aerodromai, radijo stotys, ịvairūs kiti pagalbiniai pastatai.

3. Paskelbus mobilizaciją, $\mathfrak{x}$ šị placdarmą iš visos Lietuvos teritorijos turejo būti suvaryti arkliai, skubiai susirinkti mobilizuoti atsargos kariai, juos sutikti ir priimti paskirti kadriniai kariai, skubiai aprengti, apšarvuoti ir apginkluoti, sutelkti $\mathfrak{i}$ rikiuotés vienetus, o véliau, atsižvelgiant i karo aplinkybes, pasiųsti kovoti. Čia minèti kadriniai kariai turẻjo apskaičiuoti jègos išteklius, kad kuopa išsiplèstų ị batalioną, būrys - i eskadroną, puse baterijos - i bateriją.

4. Norint pridengti iš gyvenamụjų vietovių ì placdarmą vykstančius mobilizuotus žmones ir arklius ir kartu neleisti priešininkui (net ir jo kavalerijai) iki jo prasiveržti ir sužlugdyti visą mobilizaciją, sukliudyti jam lengvai užgrobti kitas teritorijas, be minètų kadrinių karių, būtina turèti visiškai parengtą kovai tam tikrą lauko kariuomenès dalinių skaičių, pèstijos - mažiausiai devynis batalionus, kavalerijos - devynis eskadronus, artilerijos - devynias baterijas, technikos - keturis batalionus, aviacijos tris eskadriles.

3-iame punkte paminèti kadriniai kariai ir šiame punkte numatyta lauko kariuomene turejo sudaryti nemažas pajègas iš 1000 karininkų, 125 karo valdininkų, 23500 kareivių ir 7100 arklių.

5. Vietos kariuomeneje, karo istaigose ir pasienio sargybose pagal tuomečius etatus buvo 670 karininkų, 595 karo valdininkai, 14200 kareivių, joms priklausė 2045 arkliai. Šie skaičiai ateityje galëjo priklausyti nuo to, ar Krašto apsaugos ministerijai nebereikès vykdyti svetimų jai funkcijų (administracinių, rekvizicijų, politinès žvalgybos, geležinkelių apsaugos, pasienio sargybų ir t. t.).

Gen. ltn. M. Katchè pažymèjo, kad Generalinis štabas savo tolesniame darbe dèl ginkluotụjų pajeggų organizacijos, tvarkymo ir mobilizacijos iš vyriausybès turi gauti tikslų atsakymą i šiuos klausimus:

1. Ar pripažista vyriausybè, kad reikia numatytu ir galimai trumpiausiu 
laiku padidinti kariuomenę iki visos sudèties pagal galiojančius etatus?

2. Jeigu ne, ar ji pripažista, kad reikia ir galima, kol politine padètis pagerès, palikti kariuomenę tos sudèties, kurios šiuo metu ji yra?

3. Jeigu ir tai būtų pripažinta nepriimtina, kiek kariuomenè turètų būti sumažinta ${ }^{35}$ ?

Kaip matyti, Generalinio štabo vadovybès raporte dèl vyriausybès nusistatymo kariuomenés sudèț mažinti $1922 \mathrm{~m}$. pradžioje, viena vertus, aiškiai nurodytas Lietuvai gresiantis pavojus iš pietų kaimyno, kita vertus - kartu pateikta konkreti būtiniausių priemonių ir veiksmų jam atremti programa.

Pažymètina, kad 1922 m. ypač suaktyvèjo lenkų provokacijos Pietų Lietuvoje, neutraliosios zonos Valkininkų-Rūdiškių geležinkelio ir Širvintų-Giedraičių ruožuose. Pagrindinis lenkų siekis buvo šioje zonoje provokuoti susirèmimus, dèl jų suversti visą kaltę lietuviams ir šiuo pretekstu mesti prieš Lietuvą dideles karines pajègas, kurios pabandytų užimti ne tik neutraliają zoną, bet ir kitas jos teritorijas.

Lietuvos vyriausybè dèl itin sudètingos krašto ekonominès padèties, sunkiai sprendžiamų teritorinių ginčų su lenkais Tautų Sajungoje ir kitų aplinkybių buvo priversta elgtis labai apdairiai ir nesileisti su pietų kaimynu ị jokias provokacijas. Reikejjo sudaryti kuo palankesnes sąlygas sudètingoms vidaus problemoms spręsti, ypač - ekonominiam gyvenimui suaktyvinti. Tačiau, kad tai galima būtų padaryti, pirmiausia pats gyvenimas turejjo tapti ramus ir taikus.

Viena iš tokių priemonių buvo toliau mažinti ginkluotąsias pajègas, pritaikyti jas taikaus gyvenimo sąlygoms. Vyriausybei reikalaujant, $1922 \mathrm{~m}$. spalio pirmoje pusèje buvo numatyta išleisti i a atsargą iki 15000 kareivių. Tai sudare 38 proc. visos tuometès Lietuvos kariuomenès ir apie 50 proc. péstijos ${ }^{36}$. Kad toks žymus sumažinimas galutinai nedezorganizuotų kariuomenès likučių, pasikeitusiomis sąlygomis buvo būtina pertvarkyti jos organizaciją. Tai reikejo padaryti artimiausiomis dienomis, kad kariuomenès dalių ir ịstaigų viršininkai turètų pakankamai laiko tai planingai ir tvarkingai atlikti.

Generalinis štabas, iš anksto numatęs tokią galimą îvykių raidą, ėmė

\footnotetext{
35 Ten pat, 1. 28-29.

36 Generalinio štabo viršininko gen. ltn. M. Katchès 19220924 visiškai slaptas asmeninis pareiškimas kariuomenès vadui Nr. 147, LCVA, f. 929, ap. 3, b. 354, 1. 103.
} 
rengti naują sumažintos kariuomenès organizavimo planą. Šis milžiniškas darbas buvo atliktas per mėnesị. Buvo parengtas naujas sumažintu kariuomenès etatų, kurie jau kartą galiojo kaip taikos meto etatai, projektas. Generalinio štabo nuomone, jis dar nebuvo tobulas ir galutinis. Etatai buvo rengiami vadovaujantis neginčytinu dèsniu: „geresnis dažnai gero priešo" vidutinis sprendimas, energingai igyvendintas, visada geresnis už genialų sprendimą, iggyvendintą svyruojant arba visai neigyvendintą. Tad geriau turèti kad ir tokius etatus, negu jokių neturèti. Jo nuomone, šie etatai laikytini priimtinais, o trūkumus, kurie, laikui bejgant, išryškètų, be ypatingo vargo galima būtų ištaisyti. Taigi Generalinis štabas turimomis pajègomis pagal išgales savo užduotị atliko laiku.

Aukštesnems institucijoms liko tik naujuosius kariuomenès etatus peržiūrèti, sankcionuoti ir patvirtinti. Tačiau aptariamuoju laikotarpiu tai nebuvo padaryta. Rugsèjo 22 d. ịvykęs aukštųjų karo viršininkų susirinkimas, kuriam naujieji etatai buvo pristatyti svarstyti, nepateikè jokių konkrečių galutinių nurodymų: nè vieno naujo pasiūlymo, kuris vienaip ar kitaip būtų atkreipęs dèmesị. Pateiktų svarstyti pamatinių mobilizacijos klausimų, nuo kurių priklausẻ ir patys etatai, šis susirinkimas išspręsti nenorejo ar nesugebejo.

Tokiu būdu klausimas dèl kariuomenès mobilizacijos plano ir kartu dèl taikos meto etatų patvirtinimo tiek minètame susirinkime, tiek kurị laiką po jo nebuvo išspręstas ${ }^{37}$. Tai rodo aukštųjų karininkų tam tikrą nepareigingumą ir neoperatyvumą.

Kartu tenka konstatuoti, kad aptariamuoju laikotarpiu Lietuvos kariuomenès, ypač karininkijos, padètis buvo nepavydètina. Net Krašto apsaugos ministerijos tarnautojų reikalai dažnai buvo pamirštami ir nustumiami ị šalị. Neigiamų atsiliepimų apie kariuomenę neretai galima buvo išgirsti Steigiamojo Seimo posėdžiuose, visuomenès diskusijose, perskaityti kairiųjų partijų spaudoje. Pakanka paminèti savo laiku pagarsejjusị ìstatymą, kuriame tèvynès gynejjai buvo prilyginti „mažamečiams ir girtuokliams“, vèlesnį incidentą dèl nemokamo kariams vadinamojo „brangenybès" priedo, sprendimą iškelti Karo mokyklą îprastas, jai nepritaikytas patalpas Panemunèje, valdžios vykdytą Krašto apsaugos ministerijos žinioje esančių žemių kariuomenès reikmėms parceliavimą ir kt.

Ministrų kabineto nutarimas artimiausiomis dienomis paleisti iš

${ }^{37}$ Ten pat, l. 104. 
kariuomenès 15000 karių, naujokų šaukimo atidèjimas iki 1923 m. sausio 1 d., slapčiausių dalykų skelbimas viešame Steigiamojo Seimo posėdyje, Generalinio štabo nuomone, ardè taip sunkiai sukurtą kariuomenès organizaciją, užkirto kelią jos normaliam tobulinimui, atėmè galimybę tinkamai apsaugoti demarkacijos liniją, jau nekalbant apie tai, kad, prasidejjus lenku puolimui, kariuomenè būtų buvusi bejègè jiems tinkamai pasipriešinti.

Šių kenksmingų, o gal net pražūtingų priemonių poveikiui sumažinti ar net panaikinti, Generalinio štabo nuomone, reikejjo:

a) aiškiai ir galutinai nustatyti, ar mūsų valstybei reikalinga kariuomenè. Jei reikalinga, tai koks turi būti minimalus karių skaičius. Tokio dydžio kariuomenei turi būti garantuota visokeriopa moralinè parama ir reikiamas materialinis aprūpinimas. I kariuomenę reikia žiūrèti kaip ì būtiną valstybės sąlygą, o ne kaip ị posūnị arba visokių žeminančių eksperimentų objektą. Teigta, kad karo metu reikalingą ištvermę ir moralinę jègą demonstruoja tik ta kariuomenè, kuriai tokia jèga jau taikos metu ¡kvèpta suteikus atitinkamą valdžios ir visuomenès paramą;

b) neatidèliojant leisti pašaukti ị kariuomenę ne mažiau kaip 5000 naujokų, pirmiausia - dar ị ją nepašauktų vyrų, gimusių 1901 m.;

c) visas žemes, kuriomis disponavo kariuomenè, kol kas palikti Krašto apsaugos ministerijos žinioje. Laikui bėgant, galutinai paaiškejjus krašto sienoms, o kartu kariuomenès dislokacijai ir sudéčiai, nebereikalingas Krašto apsaugos ministerijai žemes planingai perduoti kitoms žinyboms ${ }^{38}$.

Tai buvo kariuomenès vado gen. ltn. J. Stanaičio ir Generalinio štabo viršininko gen. ltn. M. Katchès 1922 m. rugsėjo 30 d. gana griežta forma išdèstytas visiškai slaptas asmeninis pranešimas apie tikrąją padètị to meto kariuomeneje krašto apsaugos ministrui mjr. inž. B. Sližiui, o kartu ir visai vyriausybei. Su jos turiniu taip pat buvo supažindinti visų diviziju vadai, aviacijos, artilerijos, karo technikos viršininkai ir Generalinio štabo aukštesnieji karininkai ${ }^{39}$.

Tačiau Lietuvos vyriausybè $\mathfrak{i}$ išdèstytus reikalavimus neatsižvelgè - jai nurodžius, tų pačių metų spalio mėnesị iš kariuomenės buvo atleista 15000 kareivių. Reaguodamas ị tai, Generalinio štabo viršininkas

38 Kariuomenès vado gen. ltn. J. Stanaičio ir Generalinio štabo viršininko gen. ltn. M. Katchès 19220928 slaptas asmeninis pranešimas Nr. 1150 krašto apsaugos ministrui, ten pat, 1. 105.

39 Tokio pat turinio jų pranešimas aukštiesiems kariuomenès viršininkams, ten pat, 1. 107. 
gen. ltn. M. Katchè tų metų spalio 13 d. atsistatydino iš einamų pareigu ir buvo išleistas $\mathfrak{i}$ atsarga $a^{40}$. Generalinio štabo viršininko pareigas laikinai eiti spalio $25 \mathrm{~d}$. buvo paskirtas jo pirmasis padejejas mjr. I. Gricius, kartu èjęs ir savo tiesiogines pareigas ${ }^{41}$.

Nors ir pasitraukęs iš kariuomenès, gen. ltn. M. Katchè nepamiršo jos problemų ir dèl jų labai sielojosi. Tų pačių metų lapkričio 4 d. jis visiškai slaptame rašte naujajam Generalinio štabo viršininkui mjr. I. Griciui išdèstė savo požiūrị i kai kuriuos itin aktualius krašto gynimo klausimus ir kartu pasiūlè jų sprendimo būdus.

Gen. ltn. M. Katchès nuomone, reikètų:

1. pirmiausia - gauti aiškų atitinkamos institucijos nurodymą, kokio dydžio bus Lietuvos kariuomenè taikos metais (bent artimiausiu laikotarpiu);

2. nustatytą bendrą karių skaičių tiksliai padalyti pėstijai, kavalerijai, artilerijai, technikos ir karinèms ìstaigoms;

3. atsižvelgiant i 1-ame ir 2-ame punktuose numatytus duomenis, neatidèliojant pradèti rengti smulkų mobilizacijos planą, derinant būsimus etatus, tabelius ir t. t. Kartu reikia turèti omenyje tai, kad aplinkybès gali priversti atlikti mobilizaciją anksčiau, negu bus baigtas rengti mobilizacijos planas. Todèl, kol šis planas bus baigtas, turi būti pateikti reikalingi, kad ir neišsamūs, nurodymai. Nors jie ir negalètų garantuoti sklandžios ir tvarkingos mobilizacijos, tačiau užkirstų kelią visiškam chaosui. Be to, būtina atkreipti ypatingą dèmesị tiek ị turimų kadrinių, tiek i̇ pašauktų atsargos karių vykimo ị mobilizacijos rajonus tvarką. Svarbu iš anksto paskirti kelius, numatyti etapus ir karių maitinimo organizavimo sistemą. Visur, kur tik galima, mobilizaciją vykdyti geležinkeliais: planingas jų naudojimas gerokai pagreitintų mobilizaciją, o po to - kariuomenès telkimą operacijoms vykdyti;

4. kuo greičiau numatyti ir sutvarkyti mobilizacijos rajonus, kurie to meto sąlygomis turèjo maždaug atitikti kariuomenès sutelkimo operacijoms vykdyti reikalavimus;

5. apgalvoti ir parengti smulkų veiksmų planą tų kariuomenės dalių,

40 Krašto apsaugos ministro mjr. inž. B. Sližio 19221013 įsakymas Nr. $222 \S 1, L C V A$, f. 384 , ap. 1, b. $47,1.317$.

41 Krašto apsaugos ministro mjr. inž. B. Sližio 19221025 ịsakymas Nr. $232 \S 1$, ten pat, 1. 324 . 
kurioms bus pavesta vykdyti kariuomenès mobilizaciją ir telkimą. Tam tikslui reikia turèti nuolat parengtą visą kavaleriją ir ne mažiau kaip dvylika péstininkų batalionų, ginkluotų atitinkama artilerija. O mobilizacijos dengimą siūlè ịvykdyti, nesigilinant i smulkmenas, tokiu būdu:

a) Demobilizavus Lietuvos ir taip mažą kariuomenę, apie "frontą" negalejjo būti nẻ kalbos. Vadinasi, jokių rimtų fronto ir operatyvinių uždavinių Lietuvos kariuomenè tuometemis sąlygomis atlikti negalëjo. Todèl reikejo netrukus atitraukti kariuomenę nuo fronto, pavedus stebėti demarkacijos liniją 3-4 raitelių eskadronams, svarbiausiomis operatyvinėmis kryptimis palaikomiems pestijos užtvarų - iš viso 3-4 kuopų. To visiškai turèjo pakakti „kaimyno“ veiksmams stebèti ir jo partizanų išsišokimams paralyžiuoti. O naudoti kovos dalis pasienio kordonui laikyti ir spekuliantams gaudyti buvo netikslinga.

b) Antrojoje linijoje (Marijampolè, Alytus, Kaišiadorys, Jonava, Ukmergè ir Panevėžys) rinktinès (visos vieno bataliono su artilerija sudèties) turèjo užimti svarbesnes kryptis, mazgus ir perkèlas. Priešui puolant, šios rinktinès privalëjo pamažu trauktis link linijos Srednikai-Kaunas-Kèdainiai-Šeduva ir galimai sulaikyti priešą daugumoje iš anksto parengtų pozicijų. Šios rinktinès savo užduotị turètų vykdyti vilkindamos kovas ir vengdamos galutinio sprendimo. Antrosios linijos svarbiausius tarpus ir sparnus turejjo stebèti kavalerija.

c) Visas likusias pajegas (penkis pėstininkų batalionus su artilerija) laikyti atsargoje Kauno-Kèdainių rajone.

Dèl neišvengiamo ir visiškai suprantamo klausimo: „Kas gi bus su Kaunu?" gen. ltn. M. Katchè, suprasdamas šio miesto, kaip laikinosios sostinès, administracinio, dvasinio, prekybos ir pramonès centro, reikšmę, vis dèlto tvirtai laikèsi požiūrio, jog valstybès likimas priklauso ne nuo to ar kito punkto valdymo, o nuo "gyvos pajegos", t. y. kariuomenès, būklès. Kol gyva Lietuvos kariuomené - gyva ir Lietuva, - teigé gen. ltn. M. Katchè. Jo tvirtinimu, „vargu ar turèsime reikalą su partizanais ar nepilnai organizuotomis pajègomis, o greičiausiai teks kovoti su žymiomis ir gerai organizuotomis „kaimyno“ pajègomis“. Tokiomis aplinkybemis kovoti dẻl Kauno lemiamoje kovoje anksčiau, negu bus visiškai pasirengusi Lietuvos kariuomenè, vadinasi, pražudyti ją ir visą kraštą. Gen. ltn. M. Katchès nuomone, jei mūsų diplomatai laiku išaiškins, kad karas neišvengiamas, ir leis karinei vadovybei laiku ịvykdyti 
mobilizaciją, lemiamoji kova vyks priešui dar nepasiekus Kauno. Kitu atveju Kaunas patektų priešui be didesnio mūšio ${ }^{42}$.

Tokie buvo dalykiški patyrusio gen. ltn. M. Katchès patarimai dar mažai patyrusiam, laikinai einančiam Generalinio štabo viršininko pareigas mjr. I. Griciui. Iš jų turinio matyti, kad gen. ltn. M. Katchè buvo tikras Lietuvos patriotas, labai susirūpinęs ne tik kariuomenès, bet ir savo krašto ateitimi.

Krašto apsaugos ministras mjr. inž. B. Sližys vos pradejjusiam vadovauti Generaliniam štabui mjr. I. Griciui įsakè pateikti ataskaitą apie tuometę Lietuvos kariuomenès padètí. Tokia ataskaita pagal kariuomenès ginklų rūšis ministrui buvo pateikta $1922 \mathrm{~m}$. gruodžio $1 \mathrm{~d}$. Iš jos matyti, kad tuo metu Lietuvos kariuomeneje buvo 32000 kareivių ir apie 2500 laisvai samdomų tarnautojų ${ }^{43}$.

\section{Lietuvos kariuomenès padètis pagal atskiras ginklų rūšis}

Pèstija. Pasiruošti vykdyti kovos užduotis labai sutrukdè nelauktas ir tinkamai nepasirengus atliktas 15000 vyrų paleidimas iš kariuomenès, taip pat ilgai trukęs ir varginantis jos dislokavimas prie demarkacijos linijos. Čia kareiviai buvo išblaškyti nedidelėmis grupèmis, paviršutiniškai mokomi, buvo juntama visokių priešiškų elementų (spekuliantų, antivalstybininkų ir kt.) demoralizuojanti įtaka. Lapkričio ménesị i kariuomenę pašaukti 5000 naujokų dar nebuvo apsipratę, o jų mokymas - vos prasidėjęs. Sumažèjus karių skaičiui, pulkai buvo sudaromi ne iš trijų, o iš dviejų batalionų. Gudų batalionas buvo pertvarkytas ị atskirąją kuopą. Be to, buvo išformuotas atsargos batalionas, geležinkelių komendantūros kuopos, rengtasi išformuoti kai kurias apskričių karo komendantūras.

Kavalerija. Buvo trys pulkai: 3-iąji dragūnų „Geležinio Vilko“ pulką sudarè du eskadronai, nes trečiajam suformuoti trūko lešų. Du kavalerijos pulkai buvo kareivinèse, o vienas - išskirstytas keliuose dvaruose. Mokymas vyko tvarkingai.

Technikos kariuomenè. Jos dalys buvo labai išvargintos tvarkant krašto apleistus plentus ir tiesiant geležinkelio liniją Kazlų Rūda-Šeštokai.

Aviacija dèl lèšų stokos neįsigijo numatytų dešimties naujų lèktuvų

42 Atsargos gen. ltn. M. Katchès 19221104 visiškai slaptas raštas mjr. I. Griciui „Dèl krašto gynimo klausimų“, $L C V A$, f. 929, ap. 3, b. 354, 1. 118-119.

43 L. e. Generalinio štabo viršininko pareigas mjr. I. Griciaus 19221201 visiškai slaptas pareiškimas krašto apsaugos ministrui, ten pat, 1. 120. 
ir tebebuvo silpna.

Pasienio apsauga. Sunkiai sekèsi formuoti 2-ajj pasienio pulką. Trūko žmonių ir ginklų: lengvụjų kulkosvaidžių, patrankų ir šovinių. Karių maistas dèl daugybés produktų stokos buvo pernelyg vienodas.

Kariuomenei nepakako turimų pastatų. Carinės Rusijos valdymo metais jų buvo nemažai pastatyta, tačiau, keičiant kariuomenès padalinių dislokacijos vietas, reikèjo naujų kareivinių ir sandèlių, pirmiausia Šiauliuose, Panevėžyje, Kèdainiuose ir Raseiniuose.

Turèta sunkumų kariuomenę komplektuojant, trūko puskarininkių.

Neutraliosios zonos apsauga. Čia padètis buvo tokia: Suvalkijoje, IV pèstininkų divizijos bare (172 km ilgio), buvo 62 negausios sargybos; III ir I pėstininkų divizijų, saugojusių svarbesnes kryptis, buvo mažesni barai ir tankesnis tinklas.

Pažymètina, kad sargybos buvo išstatytos tik tose vietose, kur vyko didesnis judejimas ir, prasidejjus aktyviems karo veiksmams, tikètinomis priešo veržimosi kryptimis. Daugiau karių neturejjo ir gausesnių sargybų dalys išstatyti negalèjo, nes pulkų (dviejų batalionų dydžio) sudètis tiek sumažejo, kad sustiprinti apsaugą galimybių nebebuvo. Todèl kuopos buvo priverstos saugoti $30-40 \mathrm{~km}$ pločio barus. Esant tokiai padéčiai, priešas galëjo lengvai išardyti apsaugos tinklą ${ }^{44}$.

\section{Kautynès su lenkais neutraliosios zonos Valkininkų- Rūdiškių geležinkelio ruože $1923 \mathrm{~m}$. vasario 15-23 d.}

Dar 1921 m. vykstant deryboms Briuselyje ir Ženevoje, Lenkijos valdantieji sluoksniai, nesutinkantys daryti jokių nuolaidų Lietuvai, teisiškai pamėgino prisijungti Vilnių. Tų metų lapkričio $30 \mathrm{~d}$. L. Želigovskis paskelbẻ dekretą dèl Vilniaus Seimo rinkimų. Tai buvo numatyta $1922 \mathrm{~m}$. sausio $8 \mathrm{~d}$. Šie „rinkimai“ buvo Vilniaus prijungimo prie Lenkijos įteisinimo pirmasis etapas. Jie vyko okupacijos sąlygomis, dažnai griebiantis smurto prieš vietos gyventojus. Seimą išrinko daugiausia Vidurio Lietuvos lenkų dvarininkai ir politiniai veikèjai. Tų metų kovo $24 \mathrm{~d}$. Lenkijos Seimas patvirtino Vilniaus Seimo nutarimą, o balandžio $6 \mathrm{~d}$. buvo nutarta Vilniaus krašte ịvesti Lenkijos valdžią ${ }^{45}$. Dar $1922 \mathrm{~m}$. balandžio $1 \mathrm{~d}$.

44 Ten pat.

45 R. Žepkaitè, Diplomatija imperializmo tarnyboje, p. 156, 159. 
Lietuvos vyriausybė paskelbė notą protestuodama prieš Lenkijos Seimo nutarimą prijungti Vilniaus kraštą prie Lenkijos ${ }^{46}$.

Lietuvos ir Lenkijos santykiai èmè sparčiai blogèti $1923 \mathrm{~m}$. pradžioje. Mat, dar nustatant neutraliąją zoną, ị ją pateko dalis Gardino-Vilniaus geležinkelio (Varẻnos-Rūdiškių ruožas), ir lenkai neteko tiesioginio susisiekimo geležinkeliu Gardinas-Varèna-Vilnius galimybès. Lenkai žūtbūt siekè ši ruožą perimti savo žinion, tačiau lietuviai perleisti jo nesutiko. I ši reikalą ịsikišo Tautų Sąungos Taryba. Ji 1923 m. vasario 3 d. rekomendavo Lietuvai ir Lenkijai pasidalyti neutraliąją zoną. Lenkija šią rekomendaciją prièmé, siekdama neutraliosios zonos ribą pakeisti taip, kad galètų naudotis geležinkeliu. Tačiau Lietuva ị derybas nesileido, motyvuodama tuo, kad bet koks derẻjimasis su Lenkija būtų esamos padèties pripažinimas, o drauge ir Vilniaus bei jo krašto perleidimas Lenkijai.

1923 m. vasario mėnesị Paryžiuje vykusioje sesijoje buvo galutinai išspręstas neutraliosios zonos likvidavimo klausimas. Vasario $3 \mathrm{~d}$. Tarybos posėdžio protokole pažymèta, kad, visiems jos nariams vienbalsiai prièmus nutarimą ir jị akceptavus Lenkijos vyriausybei, Lietuvos atsisakymas pripažinti nutarimą neturèsiąs jokios reikšmès ${ }^{47}$.

Tuo metu buvo palankus metas lenkams aktyviai veikti siekiant, kad Lenkijai būtų priskirtas Valkininkų-Rūdiškių geležinkelio ruožas. Sausio 15 d. lietuvių sukilèliams užèmus Klaipèdą, Lietuva ịsivèlè ị tarptautinị ginčą, kuris užsitęsè iki 1923 m. vasario 19 d. Europos politikoje tuo metu dominavusi Prancūzija simpatizavo Lenkijai ir ją palaikè. Lietuvos vyriausybei tokiomis aplinkybėmis teko veikti labai apdairiai.

Negavę Lietuvos vyriausybės sutikimo, lenkai ryžosi Valkininkų-Rūdiškių geležinkelio ruožą užimti jèga ir šiame plote èmè telkti savo jègas. Lietuvos karinė vadovybė atidžiai stebejjo lenkų veiksmus. $1923 \mathrm{~m}$. vasario $14 \mathrm{~d}$. kariuomenès vadas gen. ltn. J. Stanaitis ịsakè visų keturių pèstininkų ir kavalerijos divizijų vadams bei Šaulių sąungos inspektoriui neleisti Lenkijai naudotis Vilniaus-Gardino geležinkeliu ${ }^{48}$.

\footnotetext{
46 Ten pat, p. 161.

47 Ten pat, p. 164.

48 KAM Generalinio štabo viršininko 19230214 slaptas ir skubus operatyvinis raštas Nr. 194 I-IV pėst. ir I kavalerijos divizijų vadams bei Šaulių s-gos instruktoriui, LCVA, f. 929 , ap. 3 , b. $425,1.42$.
} 
III pèstininkų divizijos vado mjr. I. Musteikio įsakymu 6-asis pèstininkų pulkas (vadas - plk. ltn. P. Tvaronas; du batalionai, VI ir IX baterijos, 1-ojo raitelių pulko vienas eskadronas) sustiprino sargybų budrumą saugomame bare nuo Jakènų iki Daugirdiškių kaimo. Jam buvo įsakyta neleisti lenkams prasiveržti šiapus demarkacijos linijos.

9-asis pèstininkų pulkas (vadas - kpt. B. Girštautas, du batalionai) saugojo barą nuo Daugirdiškių kaimo iki Neries upès ties Valiukiškių kaimu.

5-ajam pėstininkų pulkui (vadas - plk. ltn. V. Reklaitis; trys batalionai) buvo îsakyta vasario 15 d. 11 val. išvykti iš Kaišiadorių, per Žiežmarius-Užuguostị vasario $16 \mathrm{~d}$. 13 val. atvykti ị Aukštadvarị ir, laikantis atsargumo priemonių, būti divizijos atsargoje.

7-ajam pèstininkų pulkui (vadas - plk. ltn. J. Čaplikas; du batalionai) nurodyta būti divizijos atsargoje.

6-ajam péstininkų pulkui buvo priskirtos VI ir IX baterijos. V baterija perduota 5-ojo péstininkų pulko vado žinion, o III ir sunkioji baterijos paliktos atsargoje, divizijos štabas - Kaišiadorių geležinkelio stotyje. Intendantūros ir artilerijos sandèlis, evakuacijos punktas, automobilių būrys, 1-ojo raitelių pulko vienas eskadronas ir minosvaidžių kuopa sutalpinti Žiežmarių dvare.

Divizijos vado plk. ltn. I. Musteikio pavaduotojai buvo plk. ltn. P. Tvaronas ir plk. ltn. J. Čaplikas ${ }^{49}$.

Vasario $15 \mathrm{~d}$. IV péstininkų divizijos vadas plk. Itn. K. Ladyga divizijos kairiajam sparnui saugoti iš Alytaus ị Varẻnos-Bobriškių-Jakènų rajoną pasiuntė 12-ojo pèstininkų pulko vieną visos sudèties batalioną, pionierių būrị, pusę raitųjų žvalgų komandos ir 4-ojo artilerijos pulko XI lauko bateriją. Be demarkacijos linijos gynimo, šioms pajègoms buvo skirta daugiau užduočių: issakyta tuojau pradèti ardyti tiltus per Merkio upę ir visaip kliudyti lenkams prasiveržti ị vakarus nuo demarkacijos linijos ${ }^{50}$.

Lenkų puolimo išvakarèse neutraliosios zonos apsaugą sudarė išsidėsčiusios 6-ojo pėstininkų pulko II bataliono kuopos: 4-oji - Strielčiškių-Kalenų-Kaniūkų, 5-oji - Spenglininkų-Gudakiemio-Panošiškių-

491923 m. vasario 14 d. ịsakymas Nr. 1 III pèst. divizijai, ten pat, 1. 71-72.

50 IV pėst. divizijos štabo 19230215 telefonograma Nr. 116 Gen. štabo Operacijų skyriui, $L C V A$, ten pat, b. 360, 1. 93-94. 
Spindžiaus, 6-oji - Strèvos, Bagdanonių-Daugirdiškių kaimuose. Vienai kuopai teko saugoti apie $10 \mathrm{~km}$ pločio barą, tad sargybos buvo išdėstytos retai, nes vientiso fronto nebuvo.

Pulko štabas, I ir III batalionai ir kiti pulko daliniai buvo išsidèstę Kruonio, Darsūniškio ir Lapainos kaimuose ${ }^{51}$.

Dar 1923 m. vasario pradžioje lenkai ị Valkininkų-Rūdiškių rajoną buvo atsiuntę gausią kariuomenès dalį.

Jau vasario $12 \mathrm{~d}$. vadinamosios lenkų "partizanų“ pajègos puolè neutraliojoje zonoje $4 \mathrm{~km}$ ̣̣ vakarus nuo Valkininkų miestelio esantị Pūčkarnių kaimą, tačiau atkakliomis vietos gyventojų partizanų pastangomis iš jo buvo išvyti ${ }^{52}$.

Vasario 15 d. 6 val. ryto prasidejo Lenkijos reguliariosios kariuomenès dalių veržimasis ị neutraliąją zoną Valkininkų-Rūdiškių geležinkelio stočių ruože. Kovos buvo permainingos, abi pusès patyrè nuostolių. Vis dèlto iki tos dienos vakaro Lenkijos kariuomenei minètame ruože pavyko užimti šiuos punktus: geležinkelio liniją tarp Valkininkų ir Rūdiškių stočių, Karpiškių, Kuklių, Pūčkarnių, Vaitakarčmio, Klepočių, Vaikštenių, Ąžuolijų kaimus, Leipūnų vienkiemị ir Valkininkų geležinkelio stotị. Puolančios kariuomenès užnugaryje buvo lenkų baudžiamoji žandarmerija ${ }^{53}$.

Vasario $16 \mathrm{~d}$. Lenkijos kariuomenè, verždamasi pirmyn ị vakarus nuo Valkininkų-Rūdiškių geležinkelio linijos, prisiartino prie Lietuvos kariuomenès sargybų neutraliosios zonos pasienyje. Puldama gerokai didesnèmis pajègomis, Lenkijos kariuomenè per dieną Lietuvos sargybų linijoje užèmè nemažai kaimų.

Taip nepalankiai susiklosčius aplinkybèms, III pėstininkų divizijos vadas plk. ltn. I. Musteikis vasario 16 d. 23 val. ịsakè 6-ojo péstininku pulko vadui plk. ltn. P. Tvaronui imtis visų priemonių ankstesnei padèčiai atkurti ${ }^{54}$. 6-ojo péstininkų pulko vadas plk. ltn. P. Tvaronas, vykdydamas šị ịsakymą, pakèlè ant kojų atsargoje buvusius I ir III batalionus. Nepaisydami šalčio, užpustytų kelių, abu batalionai su pulko vado

51 Dr. A. Rukša, Kovos dèl Lietuvos nepriklausomybès, t. 3, Cleveland, 1982, p. 407.

52 V. J., Lenkų Lietuvos puolimas, Karys, 192302 22-28, Nr. 8.

53 Lenkų kariuomenès puolimas neutralios zonos Valkininkų-Rūdiškių geležinkelio stočių ruože vasario 15 d., LCVA, f. 929, ap. 3, b. 360, 1. 95.

54 III pèst. divizijos štabo 19230216 telefonograma Nr. 2026 pèst. pulko vadui, LCVA, ten pat, b. $418,1.144$. 
žinioje buvusia VI baterija itin greit pasiekė Onuškį, atlikę $40 \mathrm{~km}$ žygi.

Vykdydamos pulko vado įsakymą vasario $17 \mathrm{~d}$. 6-ojo pėstininkų pulko dalys dejjo daug pastangų, kad sargybos būtų išdèstytos kaip anksčiau. Tam buvo surengta keletas kontrpuolimų. Kai kuriuos iš jų rèmė artilerija. Iš daug kaimų lenkai buvo išvyti.

Vasario 17 d. lenkai bandè prasiveržti ir kairiajame III pėstininkų divizijos sparne. Jiems pavyko užimti keletą kaimų, tačiau kitą dieną iš šių vietovių pasitraukè ir sustojo prie Tautų Sąjungos Tarybos nustatytos linijos.

Vasario $21 \mathrm{~d}$. IV péstininkų divizijos dalys pietuose puolè lenkus, norèdamos iš jų perimti Paakmenès kaimą. Tačiau lenkų pajègos buvo stipresnès, be to, čia buvo pritraukti rezervai, todèl lietuvių puolimą atrèmé ${ }^{55}$.

Po šių susiremimų įtampa Varènos-Valkininkų bare pamažu atslūgo. Vasario $23 \mathrm{~d}$. lenkai pasitraukè iš Paakmenès, o dar po poros dienų paliko Kalėnų ir aplinkinius kaimus. Šiapus neutraliosios zonos nebeliko nė vienos lenkų užimtos vietovès. Tačiau Pamerkio-Valkininkų-Rūdiškių rajone visa neutralioji zona, taip pat Varènos-Valkininkų-Rūdiškių geležinkelis jiems atiteko. Šio ruožo lenkų užimtoje zonoje beveik visi gyventojai buvo lietuviai. Ši demarkacijos linija išliko iki 1939 m. rugsèjo ${ }^{56}$.

Pasibaigus kovoms, kariuomenès vadas gen. ltn. J. Stanaitis įsakė atitraukti kariuomenès dalis nuo baro ị nuolatines dislokacijos vietas ir kiek galint sparčiau tęsti jų mokymą. Demarkacijos linija iki tų pačių metų balandžio $30 \mathrm{~d}$. turèjo būti saugoma šia tvarka:

1. IV pèstininkų divizijai reikejjo perimti III pėstininkų divizijos saugotą barą (Jakènų kaimas-Valiukiškių kaimas prie Neries upès).

2. I pèstininkų divizijos vienas pulkas turejjo užimti barą nuo Neries upés ties Valiukiškių kaimu ir saugoti ji iki Latvijos sienos ties Kurzumo dvaru. 3-iasis dragūnų pulkas liko šios divizijos vado žinioje ir vykdè demarkacijos linijos apsaugos tarnybą.

Likusios kariuomenès dalys perejo ị šias nuolatines dislokacijos vietas:

1. III pèstininkų divizija dislokavo po vieną pèstininkų pulką Alytuje ir Marijampoleje, o 7-asis pėstininkų pulkas liko Klaipėdoje. Divizijos štabas buvo Marijampolèje.

2. I pėstininkų divizija, palikusi bare vieną pėstininkų pulką su

55 IV pèst. divizijos bare 192302 21, LCVA, ten pat, b. 160, 1. 110-111.

56 Plačiau žr.: V. Lesčius, Lenkų provokacijos neutralioje zonoje 1921-1923 metais, Karo archyvas, t. XXII, Vilnius, 2007, p. 177-188. 
3-iuoju dragūnų pulku, likusius pulkus ịkurdino Ukmergèje ir Panevėžyje. Divizijos štabas buvo Panevėžyje.

3. II pėstininkų divizijos 8-asis pėstininkų pulkas iš Panevėžio buvo perkeltas ị Šiaulių rajoną.

4. I kavalerijos divizijos 1-asis husarų pulkas liko Kaune, 2-asis ulonų pulkas ir divizijos štabas - Vilkaviškyje, 3-iasis dragūnų pulkas, vèliau atleistas nuo demarkacijos linijos apsaugos, apsistojo Utenoje ir Utenos rajone.

5. Artilerijos pulkai išsidesste taip: 1-asis - Pajuostès dvare (prie Panevėžio), 2-asis - Kèdainiuose, 3-iasis - Kaune ir jo apylinkèse, 4-asis Alytuje. Visų pėstininkų divizijų minosvaidžių kuopos buvo sutelktos Alytuje. Joms apmokyti buvo skirtas bendras instruktorius.

6. Inžinerijos pulko kuopos liko: 1-oji - prie I, 2-oji - prie II, 3-ioji prie III pėstininkų divizijos. Kuopų priklausomybė ir jų organizacija nepakito. Šių kuopų karinis rengimas ir aprūpinimas visais reikmenimis liko inžinerijos pulko vado žinioje. 4-oji inžinerijos pulko kuopa perejjo ị Kauną savo pulko vado žinion ir ten dislokavosi.

7. Šarvuotojo diviziono dalys, priklausiusios divizijoms, perejo diviziono vado žinion ir įsikūrè Kaune. Šio diviziono vadas vieną šarvuočių būrị su jam aptarnauti reikalingu personalu išsiuntė $\mathfrak{i}$ Klaipèdą, tačiau pasiliko savo žinioje.

Visos kitos ịsakyme neišvardytos kariuomenès dalys ir ịstaigos liko savo vietose. Atsarginiai pèstininkų divizijų sandèliai buvo įkurti: I - Šeduvoje ir Panevėžyje, II - Šiauliuose, III - Raseinių rajone.

Visos kariuomenès dalys, ypač buvusios arčiau demarkacijos linijos (Vilkaviškyje, Marijampolèje, Alytuje, Ukmergèje ir Utenoje), privalèjo turèti omenyje, kad yra netoli priešininko ir bet kuriuo metu gali laukti ịsakymų vykdyti operatyvines užduotis ${ }^{57}$. Iš to, kas anksčiau pasakyta, matyti, jog, remiantis kariuomenès vado ịsakymu, jos organizacijoje ir dislokacijoje ịvyko esminių pokyčių - $1921 \mathrm{~m}$. gruodžio $8 \mathrm{~d}$. paskelbta direktyva Nr. 9 nustojo galioti.

Ministrų kabineto 1923 m. gegužès 2 d. nutarimu IV pėstininkų divizija buvo išformuota ir sukurta Pasienio sargybų divizija. Jos štabas buvo Alytuje. Divizijos vadu buvo paskirtas plk. ltn. K. Žukas. I jos sudèti ịejo 1-asis (buv. 1-asis pasienio pulkas), 2-asis (buv. 10-asis pèst.

57 Kariuomenès vado gen. ltn. J. Stanaičio 19230420 visiškai slaptas įsakymas kariuomenei Nr. 1, LCVA, f. 761, ap. 1, b. 73, 1. 50-51. 
Marijampolès pulkas), 3-iasis (buv. 11-asis pèst. Vilniaus pulkas) ir 4-asis (buv. 12-asis pèst. Kauno pulkas) pasienio pulkai. Buvęs 2-asis pasienio pulkas buvo išformuotas ${ }^{58}$. Ši divizija perejo Vidaus reikalų ministerijos žinion.

Išdèstant kariuomenę nuolatinèse dislokacijos vietose krašto apsaugos ministro $1923 \mathrm{~m}$. birželio $30 \mathrm{~d}$. slaptu itsakymu Lietuvos Respublikos teritorija buvo padalyta i 3 karo apygardas, joms vadovauti buvo paskirtas karo apygardos viršininkas - divizijos vadas. Visų pėstininkų divizijų dalys taikos metu dislokavosi atitinkamose karo apygardose. Buvo paskirta:

I pèstininkų divizijai - I karo apygarda, ị kurią ịejo Panevèžio, Ukmergès, Utenos, Zarasų (Ežerènų), Rokiškio ir Biržų-Pasvalio apskritys;

II pèstininkų divizijai - II karo apygarda, ị kurią ịejo Kauno, Trakų, Kèdainių, Šiaulių, Telšių, Mažeikių ir Kretingos apskritys;

III pèstininkų divizijai - III karo apygarda, ị kurią ièjo Marijampolès, Seinų, Alytaus, Vilkaviškio, Šakių, Raseinių, Tauragės apskritys ir Klaipėdos kraštas ${ }^{59}$.

Tam tikrų pokyčių ịvyko ir pačioje kariuomenès vadovybèje. Pašlijus sveikatai, nuo $1923 \mathrm{~m}$. birželio $5 \mathrm{~d}$. iš kariuomenès vado pareigų atsistatydino gen. ltn. J. Stanaitis ${ }^{60}$. Tų pačių metų birželio 6 d. Respublikos Prezidentas A. Stulginskis gen. S. Žukauską atšaukè iš atsargos ir vèl paskyrè kariuomenès vadu ${ }^{61}$. Generolas nenoriai èmèsi šių pareigų, tačiau po gana ilgų derybų sutiko.

Pasibaigus 1923 m. vasario 15-23 d. kariniam lenkų ir lietuvių konfliktui, gyvenimas kurị laiką buvo palyginti taikus. Pagrindinis kariuomenès vadovybès uždavinys buvo perorganizuoti kariuomenę pritaikant ją taikos meto sąlygoms. Tačiau šis darbas sunkiai ejo. Pagrindinè kliūtis buvo vyriausybès reikalavimas toliau mažinti kariuomenę ir Seimo Biudžeto komisijos nenoras tvirtinti jos naujų etatų. Parengti jų projektai šioje komisijoje ištisus mènesius išgulejo nesvarstyti arba, net jos

58 Pasienio sargybų divizijos suformavimas, krašto apsaugos ministro 19230622 slaptas issakymas kariuomenei Nr. $7 \$ 2, L C V A$, f. 384, ap. 1, b. 15, 1. 110.

59 Krašto apsaugos ministro 19230630 slaptas įsakymas kariuomenei Nr. $8 \S 1$, ten pat, 1. 114 .

${ }^{60}$ Krašto apsaugos ministro 19230607 slaptas įsakymas kariuomenei Nr. $106 \S 1$, ten pat, b. 53, 1. 129.

61 Krašto apsaugos ministro 19230607 slaptas įsakymas kariuomenei Nr. 108, ten pat, 1. 138 . 
peržiūrèti, tačiau atsakingų institucijų nepatvirtinti, buvo grąžinami atgal ir realiai negalèjo būti vykdomi.

Be to, vykdant ministrų kabineto sprendimą, 1923 m. tinkamai nepasirengus ir neatsižvelgus i atgautą Klaipėdos kraštą ir minètus ịvykius prie demarkacijos linijos, dèl sunkios krašto finansinès padèties beveik perpus sumažinus kariuomenę, reikèjo skubiai pereiti prie naujų etatų, norint užtikrinti, kad ir minimalų, kariuomenès dalių aprūpinimą. Pasak 1. e. Generalinio štabo viršininko pareigas plk. ltn. J. Griciaus, „susidarè įspūdis, jog norèta galutinai likviduoti kariuomenę“. Jis teigè, kad tokiomis sąlygomis reikèjo rasti žmonių, kurie būtų sugebejję panašiomis aplinkybemis dirbti, o jis pats toliau eiti savo pareigų negalìs. Šiai plk. ltn. J. Griciaus pareikštai nuomonei pritarè ir naujasis kariuomenès vadas gen. S. Žukauskas ${ }^{62}$.

I plk. ltn. J. Griciaus prašymą buvo atsižvelgta - nuo $1923 \mathrm{~m}$. rugsejjo 20 d. jam buvo leista eiti tik tiesiogines Generalinio štabo viršininko pirmojo padejejjo pareigas, o Generalinio štabo viršininku buvo paskirtas patyręs gen. L. Radus-Zenkavičius ${ }^{63}$.

Po 1923 m. kovo 15 d. Ambasadorių konferencijos, pripažinusios Vilnių ir kitas ginčijamas žemes Lenkijai, sprendimo Lietuva nebegalejo tikètis Tautų Sąjungos paramos bandydama susigrąžinti prarastas teritorijas. Su šia realija teko skaitytis visoms Lietuvos vèlesnèms vyriausybėms, o kartu ir kariuomenės vadovybėms. Tačiau atsisakyti Vilniaus Lietuva nesirengè. Nepajėgdami susigrąžinti Vilniaus jègos metodais, lietuviai pasirinko galimo „karo stovio“ su Lenkija būseną. „Nei karo, nei taikos“ padètis leido jiems išsaugoti viltị kada nors ateityje Vilnių ir Vilniaus kraštą susigrąžinti. Lietuvos ir Lenkijos priešprieša tęsėsi.

\section{Vyriausiojo štabo Operacijų skyriaus $1926 \mathrm{~m}$. gegužès 15-16 d. direktyva (pirmasis projektas)}

1926 m. gegužès $12 \mathrm{~d}$. Lenkijoje prasidejo politinis perversmas, privedęs net prie kruvinų susirèmimų pačioje Varšuvoje. Maršalas J. Pilsudskis,

62 L. e. Generalinio štabo viršininko pareigas plk. ltn. J. Griciaus 19230831 visiškai slaptas pareiškimas Nr. 12 krašto apsaugos ministrui, LCVA, f. 929, ap. 3, b. 408, 1. 68.

63 Krašto apsaugos ministro 19230920 įsakymas kariuomenei Nr. $202 \S 1$ ir $\$ 2, L C V A$, f. 384 , ap. 1, b. 53, 1. 249. 1924 m. pradžioje Generalinis štabas buvo performuotas i Vyr. štabą (V. L.). 
remiamas palankių kariuomenès dalių, sukèlè maištą prieš Vitoso sudarytą vyriausybę. Gegužès 15-16 d. jam pavyko sudaryti naują Lenkijos ministrų kabinetą. Ji tuoj pat pripažino III lenkų korpuso (III D. O. K.) vadovybè. Šio korpuso daliniai, kaip jau minèjome, buvo išsidèstę užgrobtame Vilniaus krašte.

J. Pilsudskio grižimas prie Lenkijos valdžios vairo lietuviams asocijavosi su jo vaidmeniu 1919-1920 m. ịvykiuose ir Vilniaus krašto užgrobimu. I i ivykius Lenkijoje jautriai reagavo tiek Lietuvos vyriausybė, tiek kariuomenès vadovybè. Tuo metu krašto apsaugos ministras buvo plk. T. Daukantas, Vyr. štabo viršininkas - gen. ltn. K. Ladyga.

Vyr. štabo Operacijų skyrius jau 1926 m. gegužès 15-16 d. parengè visiškai slaptos direktyvos kariuomenei pirmajji projektą. Joje išdèstė savo nuomonę, kaip minèti įvykiai Lenkijoje galejo paveikti Lietuvos santykius su pietiniu kaimynu. Atsižvelgiant $\mathfrak{i}$ tai, kad šis perversmas vyko remiant kariuomenei, naujajai lenkų valdžiai galejo kilti noras sutvirtinti savo padètị atkreipiant kariuomenès ir visuomenès dèmesị $\mathfrak{i}$ Lenkijos interesus Lietuvoje. Be to, daugiau galimybių turéjo ir pavieniai asmenys (provokatoriai), kurių iniciatyva pasienyje galejo būti sukelta incidentų ir j̇žiebtas ginkluotas konfliktas. Visa tai puikiai suvokiant, buvo ịsakyta Lietuvos kariuomenei pasirengti karo veiksmams su lenkais ${ }^{64}$. Numatomų veiksmų pobūdis - gynybinis.

Bendras Lietuvos karinių pajègu pasirengimas kovoms su lenkais turèjo apimti jų mobilizaciją ir sutelkimą. Pirmiausia reikèjo organizuoti mobilizacijos ir sutelkimo priedangą ir surinkti apie priešą reikiamas žinias. Mobilizacijai atlikti buvo parengti atitinkami planai.

Sutelkimo tikslas buvo: 1) sutelkti kariuomenę, aprūpintą visomis karinèms operacijoms reikalingomis priemonèmis, rajone, iš kurio, veikiant sutelktomis pajègomis, būtų pasiektas iškeltas tikslas - sustabdytas lenkų brovimasis i Lietuvos teritoriją; 2) evakuoti iš rajono, kuriam grèstų priešų antplūdis, visa tai, kas galètų būti naudinga krašto kariuomenei arba kuo galètų pasinaudoti priešas saviems tikslams; atitinkamai turi būti sutvarkytas užnugaris ir transporto tarnyba; 3) laikas - nurodytas atskirai; 4) kariuomenès sutelkimo vieta - Kauno-Jonavos rajonai.

${ }^{64}$ Vyr. štabo Operacijų skyriaus 192605 15-16 visiškai slapta direktyva (pirmasis projektas), LCVA, f. 929 , ap. 3, b. 538, 1. 48-50. 
Konflikto atveju Lietuvos kariuomenès dalys turejjo susitelkti šiose vietose:

I pèstininkų divizija: 3-iasis pėstininkų pulkas - Alytuje (lieka ir pereina $\mathfrak{i}$ III pèstininkų divizijos sudèti), 4-asis pėstininku pulkas - Panevěžio apylinkèse, 1-asis pėstininkų pulkas - Veprių apylinkėse, 1-asis artilerijos pulkas - Markutiškių dvare, kur įsikurtų ir I pèstininkų divizijos štabas.

II péstininkų divizija: 2-asis pėstininkų pulkas - Kaune, 5-asis pèstininkų pulkas - taip pat Kaune. 6-asis pèstininkų pulkas iš Šiaulių turejo persikelti $\mathfrak{i}$ Žeimius, ten pat susitelkti ir 2-asis artilerijos pulkas. 3-iąji artilerijos pulką ir II pėstininkų divizijos štabą numatyta palikti Kaune.

III pèstininkų divizija: 6-asis pėstininkų pulkas - Alytuje, 9-asis pèstininkų pulkas - Marijampolejje, 7-asis pėstininkų pulkas ir 1-ojo artilerijos pulko I baterija turèjo susitelkti Jonavoje, o III pėstininkų divizijos štabas ịsikurti Marijampolèje.

Raitelių brigada: 1-asis husarų pulkas - Kaune, 2-asis ulonų pulkas - persikelti iš Vilkaviškio ị Ukmergę, Mokomasis eskadronas - pasilikti Marijampolèje III pėstininkų divizijos vado žinioje.

Šarvuočių rinktinè turèjo pasilikti Kaune.

Aviacijos bazę numatyta perkelti ị Nemakščių rajoną, o visi naudoti tinkami lèktuvai, juos aptarnaujantis personalas, degalų ir tepalų atsargos dviem savaitèms liktų Kaune.

Technikos pulkas taip pat bùtų Kaune.

Naujai formuojami pulkai turejo pasilikti: 10-asis pasienio Marijampolès pulkas - Šiauliuose, 11-asis pasienio Vilniaus pulkas - Panevèžyje, 12-asis pasienio Kauno pulkas - Panemuneje.

Krašto apsaugos ministerijos centrinès įstaigos ir vyriausioji būstinè liko Kaune ${ }^{65}$.

Taigi pirmosiomis dienomis po perversmo Lenkijos puolimo grèsmé Lietuvoje buvo vertinama rimtai. Vyriausiajame štabe vienas po kito vyko nervingi posėdžiai. Gegužès $16 \mathrm{~d}$. kariuomenė gavo Vyriausiojo štabo įsakymą būti parengusiai gynybinio pobūdžio karo veiksmams su Lenkija. Padaryti būtini kariuomenès dislokacijos pakeitimai, sustiprinta demarkacijos linijos apsauga. Padèties rimtumą rodè ir gegužès $18 \mathrm{~d}$.

${ }^{65}$ Ten pat. 
vyriausybės posėdyje, dalyvaujant valstybės Prezidentui A. Stulginskiui ir Ministrui Pirmininkui L. Bistrui, svarstytas mobilizacijos klausimas. Taupumo sumetimais ir bijant išprovokuoti lenkus, nutarta ne tik visuotinès, bet ir dalinès mobilizacijos neskelbti ${ }^{66}$. Birželio pradžioje perskirstant aukštuosius karininkus buvo pakeista 15 karininkų ${ }^{67}$.

Buvo pakeista ir kariuomenès vadovybè. Respublikos Prezidento aktu $1926 \mathrm{~m}$. birželio $16 \mathrm{~d}$. krašto apsaugos ministro pareigas pradejo eiti plk. ltn. J. Papečkys ${ }^{68}$. Vietoj atleisto Vyr. štabo viršininko gen. ltn. K. Ladygos ị šias pareigas birželio $22 \mathrm{~d}$. buvo paskirtas Nepriklausomybès kovose jau užsigrūdinęs karininkas, $1925 \mathrm{~m}$. baigęs Belgijos karo akademiją Briuselyje, plk. ltn. K. Škirpa ${ }^{69}$.

\section{Vyriausiojo štabo viršininko plk. ltn. K. Škirpos $1926 \mathrm{~m}$. gynybos planai}

Pradėjęs vadovauti Vyr. štabui, plk. ltn. K. Škirpa, perèmęs savo žinion 14 svarbių dokumentų iš aukščiausių karinių pareigūnų ir ịvertinęs šią medžiagą, tų pačių metų liepos $27 \mathrm{~d}$. visiškai slaptame raporte krašto apsaugos ministrui plk. ltn. J. Papečkiui pateikè savo konstatuojamojo pobūdžio samprotavimus apie padètị Lietuvos ginkluotosiose pajegose ir jų kovinę parengtị.

Šiame dokumente buvo išsamiai apibūdinta taikos meto visų rūšių kariuomenès organizacija ir sudètis, Krašto apsaugos ministerijos centriniụ ịstaigų (Vyr. štabo, Tiekimo valdybos ir Kariuomenès teismo) funkcionavimo, karininkų, puskarininkių parengimo ir kareivių mokymo lygis, mobilizacijos vykdymo, krašto gynimo, kariuomenès medžiaginio aprūpinimo problemos. Šiose srityse buvo rasta daug trūkumų.

Plk. ltn. K. Škirpos teigimu, tokios organizacijos kariuomenè neatitinka krašto gynimo problemos. Ji labai neekonomiška: tai „skeletas“ su daugybe štabų, dideliu ūkio, administracijos ir kitu kariuomenei

\footnotetext{
66 V. Žalys, Lietuvos diplomatijos istorija (1925-1940), t. 1, Vilnius, 2007, p. 124.

67 Krašto apsaugos ministro dr. L. Bistro 19260602 issakymas kariuomenei Nr. 53, LCVA, f. 384 , ap. 1 , b. $73,1.85$.

68 Ten pat, 1. 93.

69 Krašto apsaugos ministro plk. ltn. J. Papečkio 19260630 įsakymas kariuomenei Nr. 62 $\S 1$, ten pat, 1. 94 .
} 
aptarnauti reikalingu aparatu, o kareivių yra mažai. Pagal 1925 m. lapkričio $27 \mathrm{~d}$. Seimo patvirtintus taikos meto etatus kariuomenę turëjo sudaryti 15469 kariai, o faktiškai buvo 11 714, arba 75,8 proc. numatyto bendro jų skaičiaus. Svarbiausios šio neatitikimo priežastys buvo: 1) $1925 \mathrm{~m}$. neplaningai ir skubotai atliktas kariuomenès sumažinimas; 2) nenuoseklus perejimas nuo $2-3$ iki 1-1,5 m. karo tarnybos; 3 ) nevykęs naujokų šaukimas $1926 \mathrm{~m}$. pradžioje; 4) per daug atleistų nuo karo tarnybos dèl sveikatos būklès; 5) kai kurie vyriausybès potvarkiai, neleidę užimti etatu' ${ }^{70}$.

Vyr. štabo, Tiekimo valdybos ir Kariuomenès teismo veikla nebuvo reglamentuota. Iki tol netureta Krašto apsaugos ministerijos statuto, nebuvo sureguliuotos atskirų viršininkų teisès, pareigos ir tarpusavio santykiai. Todèl tarp jų kildavo ịvairių nesusipratimų, kurie gadino gerus santykius, itraukdavo ir jų pavaldinius ị intrigas. Visa tai kenke ne tik ju darbui, bet ir bendrai kariuomenės drausmei. Turint omenyje karių skaičių, Vyr. štabas buvo per daug sudètingas ir didelis. Jị sudarè 3 valdybos: 1) Generalinio štabo, 2) Karo mokslo ir 3) Administracijos, o kiekvieną jų - 3-4 skyriai. Skyrių ir valdybų kompetencija buvo neapibrèžta. Dèl to neretai panašaus pobūdžio klausimai buvo sprendžiami ịvairiuose skyriuose. Faktiškai visas darbas juose ir vyko, o valdybų viršininkai buvo tik operatyviam darbui trukdantys tarpininkai tarp skyriu ir Vyr. štabo viršininko, be kurio sprendimo joks svarbesnis klausimas negalejo būti išspręstas. Štabo organizacinẻ sistema buvo neekonomiška ir valstybei nelabai naudinga, nes jo viršininkas, nepakankamai glaudžiai bendraudamas su skyriais ir veikdamas per tarpininkus (valdybų viršininkus), negalëjo duoti tinkamo impulso, kad skyriuose darbas vyktų sklandžiai. Tokia Lietuvos kariuomenès Vyr. štabo struktūra, kokia tuo metu buvo, galejo tikti tik kurios nors didelès valstybès kariuomenès štabui. Plk. ltn. K. Škirpos nuomone, ji buvo nukopijuota nuo Rusijos prieškarinès organizacijos ${ }^{71}$.

Pernelyg sudètinga buvo ir Tiekimo valdybos struktūra. Kaip ir Vyr. štabo, ji nebuvo pritaikyta tokio dydžio kariuomenei. Tiekimo viršininkas buvo trukdantis operatyviai veiklai tarpininkas tarp tiekimo

${ }^{70}$ Vyr. štabo viršininko plk. ltn. K. Škirpos 19260727 visiškai slaptas raportas Nr. 767 krašto apsaugos ministrui, LCVA, f. 929, ap. 3, b. 536, 1. 1-5.

71 Ten pat, 1. 5-7. 
skyrių (intendantūros, artilerijos ir technikos tiekimo) ir krašto apsaugos ministro. Norint to išvengti, reikèjo suteikti jam daugiau teisių ir nustatyti realią atsakomybę už kariuomenès aprūpinimą. Apskritai Krašto apsaugos ministerijos centrinių i̇staigu personalas nebuvo specializuotas ir tinkamai parengtas štabo darbui. Be to, jis buvo labai gausus, daugelis asmenų naudojosi pernelyg didelèmis teisèmis. Tuo metu turèta vos apie 12000 kareivių, kurie būtų sudarę tik diviziją, o karininkai galèjo užimti armijos, susidedančios iš 4 korpusų, etatus ${ }^{72}$.

Be šių to meto kariuomenès organizacinių trūkumų, plk. ltn. K. Škirpa nurodè ir daugybę kitų:

1) nebuvo galimybių tinkamai organizuoti pratybų seniai tarnaujantiems kareiviams, nes jų buvo mažai: norint surengti atitinkamus mokymus, tekdavo rinkti žmones iš visų pulko komandų, tačiau tokį mišrų kontingentą buvo labai sunku mokyti;

2) nors dèl pietinio kaimyno politikos Lietuvos padètis buvo sunki, neturèta galimybių organizuoti bent kiek geresnès mobilizacijos priedangos;

3) pèstijos dalių etatai buvo ịsteigti neturint jokios organizacinès koncepcijos - jie nepagrịsti modernia karo doktrina;

4) kavalerijos organizacija buvo labai pasenusi;

5) artilerijos pulkų ginklai buvo ịvairių kalibrų ir modelių, todèl kareivius reikejjo individualiai mokyti; kiekviena baterija turèjo savo ūkị, o tai buvo neekonomiška ir nepraktiška;

6) sujungti technikos dalis ị vieną technikos pulką buvo netinkamas sprendimas, nes tokiu atveju pulko vadas turejjo išmanyti visas karo technikos sritis, t. y. būti universalus specialistas: ir pionierius, ir karo inžinierius statybininkas, ir inžinierius geležinkelininkas, ir mechanikas, ir elektrotechnikas, ir t. t. Taigi iš technikos pulko vado buvo reikalaujama labai daug;

7) ị šarvuočių rinktinès sudètị iẻjo ir šarvuotụjų traukinių batalionas, kurio egzistavimas taikos metu negalejo būti pateisinamas kokiais nors taktiniais tikslais, nes per karą šarvuotieji traukiniai labai retai kada būdavo naudojami mūšyje;

8) aviacija turejjo per daug aptarnaujančiojo personalo, o jos organizacinè struktūra buvo neekonomiška ${ }^{73}$.

72 Ten pat, 1. 8.

73 Ten pat, 1. 9. 
Kadrinių karininkų rengimas vyko karininkų kursuose ir kariuomenès dalyse. Karininkų kursai neturèjo aiškaus tikslo, ką planuoja pasiekti. Rengiant jų programas ir darbo planus, Vyr. štabas neturejo jokios ịtakos, todèl kursai ir mokyklos veikè taip, kaip vadovavo jų viršininkai. Nors karininkams rengti buvo skiriama nemažai lèšų, dèl nenuoseklumo jų rezultatai negalèjo būti laikomi pakankamais. Karininkai buvo nevienodo ir nepakankamo karinio pasirengimo, o tai labai kenkẻ kareivių mokymui. Ypač prastai buvo parengti įvairių sričių karininkai specialistai: pionieriai, artileristai ir kt. Aukštesniųjų viršininkų (divizijų ir pulkų vadų) kvalifikacijai kelti nieko nebuvo nuveikta. Atsargos karininkų rengimas buvo pamirštas.

Puskarininkių rengimas mokomosiose kuopose ir komandose taip pat buvo prastas. Tai priklausè ne tik nuo tam skiriamo laiko (apie 6 mèn.), bet nuo jas sudarančių karių menko išsilavinimo. Dažnai ị puskarininkių mokyklas stodavo asmenys, vos mokantys net savo pavardę parašyti.

O kareivių tiesiog nebuvo kam mokyti. Tuometė pulkų organizacinè struktūra buvo taip nevykusiai sutvarkyta, o jie patys tokie maži, kad vidaus tarnybai eiti reikejjo daugiau kaip pusès nors šiek tiek pamokytų kareivių. Tačiau tam dažniausiai likdavo labai mažai senų (patyrusių) kareivių. Reguliariai rengti mokymus leista tik naujokams, kol būdavo išeinama numatyta programa. Po to dèl žmonių stokos jokio tolesnio rimto, sistemingo mokymo nevykdavo, nes tam nebuvo galimybių. Eidami sargybą, dirbdami ūkio darbus, vykdydami kitas tarnybos pareigas, komandiruotèse kareiviai pamiršdavo viską, ką, būdami naujokai, buvo išmokę. 1925 m. bandyta atsarginius mokyti, tačiau iš to nieko neišejo. Taigi tiek atsargos kareivių, tiek karininkų žinios nebuvo atnaujinamos.

Kilus karinio konflikto pavojui, Lietuvos ginkluotosios pajègos mobilizacijai nebūtų pasirengusios. Tuo metu niekas negalejo pasakyti, kiek laiko tam būtų reikèję. Spèjama, kad ne mažiau kaip 8-10 dienų. Plk. ltn. K. Škirpos nuomone, tada būtų buvęs "pilniausias chaosas" ${ }^{\text {" } 74}$.

Krašto gynimo problemos atsispindejo tik diskusijose. Perimdamas Vyr. štabo viršininko pareigas, plk. ltn. K. Škirpa negavo jokio karo veiksmų plano. Spèta, kad štabas jo apskritai neturejjo. Nebuvo išstudijuotos galimos karo veiksmų zonos, o divizijos neorientuotos kryptingai

74 Ten pat, 1. 11, 14. 
veikti staigaus priešo puolimo atveju. Konstatuota, kad krašto gynimo srityje nieko arba labai mažai nuveikta. Plk. ltn. K. Škirpos nuomone, šiuo klausimu susirūpinta tik tada, kai Lenkijoje ịvyko Pilsudskio vadovaujamas sukilimas. Tuomet Lietuvos kariuomenès Vyr. štabe prasidejjo posèdžiai ir svarstymai, ką reikètų daryti, suvokta, jog krašto padètis labai bloga, todèl būtina imtis griežtų priemonių, kad lenkams staigiai puolant būtų galima išvengti katastrofos ${ }^{75}$.

Išstudijavęs ir įvertinęs iš aukštesniųjų karininkų gautą medžiagą, plk. ltn. K. Škirpa prièjo prie išvados, kad šalies ginkluotųjų pajègu padètis, kartu ir gynybos situacija, yra labai prasta. Krašto gynimo reikalams skiriamos lèšos nepagrịstai eikvojamos, netinkamas karių mokymas, neapsaugotos valstybės sienos, nepasirengta mobilizacijai, nėra pakankamai ginklų, šovinių atsargų, finansinių išteklių.

Esant tuometei politinei situacijai, didžiausia grèsmè kilo iš Lenkijos pusès. Vien okupuotoje Lietuvos dalyje taikos metu dislokuotos jos pajègos buvo du kartus didesnès už lietuvių. Taigi lenkai galèjo užklupti lietuvius visiškai nepasiruošusius gintis ${ }^{76}$. Tokia buvo tuomete krašto gynybos sistemos padètis.

Plk. ltn. K. Škirpos tvirtinimu, sprendžiant krašto gynimo problemą, reikejo remtis visais konkrečiais elementais, t. y.:

2) pakankama mobilizacijos priedanga;

3) tinkama ginkluotụjų pajègų organizacija, parengta atsižvelgiant $\mathfrak{i}$ krašto išteklius ir tarptautinę karinę padèti;

4) pakankamomis karo atveju išteklių atsargomis;

5) skubia mobilizacija, mobilizuotų pajègų permetimu ir sutelkimu taikos metu numatytoje zonoje, kurioje jos geriausiai dengtų priešo veržimosi i Lietuvos teritoriją kryptị.

Raporto pabaigoje plk. ltn. K. Škirpa krašto apsaugos ministrui pareiške „norịs atsiriboti nuo to, kas buvo jo pirmtako gen. ltn. K. Ladygos daroma ir padaryta, nes už jo darbo pasekmes, kurios dar negreit išdilsiančios, imti atsakomybę ant savęs negalįs" ${ }^{\text {"77 }}$.

Kaip matyti, šiame visiškai slaptame raporte krašto apsaugos ministrui plk. ltn. J. Papečkiui Vyr. štabo viršininkas plk. ltn. K. Škirpa

75 Ten pat.

76 Ten pat, 1. 15 .

77 Ten pat, 1. 16. 
išdèstẻ savo poziciją dèl šalies ginkluotụjų pajègų organizacijos ir krašto gynimo. Kadangi tai buvo svarbiausias valstybinis reikalas, galintis turèti didelę reikšmę Lietuvos ateičiai, plk. ltn. K. Škirpa jautè pareigą, be raporto, krašto apsaugos ministrui šiais klausimais pateikti papildomus samprotavimus. Jie buvo išdèstyti visiškai slaptame asmeniniame raporte Nr. $767^{\text {a }}$ tą pačią dieną - $1926 \mathrm{~m}$. liepos 27 -ąją ${ }^{78}$.

I. Motyvai, kurie vertè peržiūrèti buvusią ginkluotųu paj pajgų organizaciją ir ją keisti, buvo šie:

1. Kaip jau minèta, tuometė kariuomenès organizacija nebuvo pritaikyta krašto gynimo problemai spręsti atsižvelgiant ị realią karinio konflikto galimybę, kuri išplauke iš Lietuvos politinių ir karinių santykių su kaimynais, pirmiausia su Lenkija. Toks konfliktas galèjo įvykti bet kuriuo metu, nes su šia valstybe nebuvo teisètos sienos ir pakankamai svarių formalių garantijų, jog lenkai lietuvių nepuls.

Kita vertus, Vilniaus srityje buvo tiek lenkų pajėgų, kad jos galejjo pulti staiga, t. y. dar neįvykus Lenkijoje mobilizacijos. O Lietuvos taikos meto kariuomenè, susidedanti iš „skeletinių“ pulkų ir nemobilizuota, buvo per silpna, kad galètų rimtai joms pasipriešinti. Kadangi Lietuvoje mobilizacijai įvykdyti tuo metu reikejjo 8-10 dienų, lenkams staiga užpuolus (o taip elgtis juos būtų privertusios politinès aplinkybės), Lietuvos kariuomenè būtų užklupta dar jai nesibaigus. Kokie galèjo būti tokio įvykio padariniai - aiškinti nereikia.

2. Lietuvos ginkluotụjų pajègų organizacijoje nebuvo numatyta pajègų mobilizacijai pridengti. Dèl to jos priešai, nesutikę jokio pasipriešinimo, galejjo pirmomis konflikto valandomis, net ir disponuodami nedidelèmis pajègomis, ịsiveržti ị šalies teritoriją, padaryti daug nuostolių ir sutrukdyti Lietuvos kariuomenei mobilizuotis. Tokiu atveju tektų ypač atsižvelgti i gana gausią lenkų kavaleriją, kuri buvo dislokuota okupuotoje Lietuvos dalyje. Taikos metu lenkai Lietuvoje turèjo:

Vilniuje - du raitelių pulkus ir vieną raitosios artilerijos divizioną;

Pabradeje - vieną raitelių pulką;

Suvalkuose - du raitelių pulkus ir vieną raitosios artilerijos divizioną; Augustave - vieną raitelių pulką.

78 Vyr. štabo viršininko plk. ltn. K. Škirpos 19260727 visiškai slaptas raportas Nr. 767 krašto apsaugos ministrui, LCVA, f. 929, ap. 3, b. 536, 1. 149. 
Iš viso šias kavalerijos pajègas sudarè apie 4000 raitelių ir 24 patrankos.

3. Lietuvos kariuomenès organizacija buvo neekonomiška, nes turejjo palyginti daug štabų, ùkio ir administracijos personalo (kuri valstybei brangiai kainavo išlaikyti), bet mažai rikiuotės kareivių.

4. Tuometès sudèties pulkuose dèl žmonių trūkumo buvo neįmanoma mokyti vadinamųjų senų kareivių, t. y. išejjusiųjų naujokų mokymo programą. Nebuvo galimybių organizuoti bataliono ir pulko užsiemimų, o kuopos mokymai galejo vykti tik tada, kai iš įvairių kuopų ir komandų buvo surenkamas reikiamas karių skaičius.

Čia paminèti motyvai buvo labai svarūs. Jų visiškai pakako, kad būtų peržiūrèta buvusi taikos meto kariuomenès organizacija ir nuspręsta ją keisti. Be šių svarbiausių Lietuvos kariuomenės ydų, dar buvo ir kitų, ne tokių reikšmingų, trūkumų, kuriuos buvo galima ištaisyti nekeičiant kariuomenès organizacijos iš esmès.

II. Reikalavimai, kuriuos turejjo atitikti Lietuvos ginkluotosios pajègos, buvo strateginiai, organizaciniai ir finansiniai.

Lietuva, kaip maža valstybè, negalejo pretenduoti ì svetimas teritorijas, tikètis jas užgrobti. Svarbiausias jos uždavinys buvo apginti savo teritoriją nuo priešo puolimų. Bet aptariamuoju laikotarpiu ne visos Lietuvos dalys buvo išvaduotos. Vilnius vis dar buvo okupuotas lenkų. Susiklosčius palankioms sąlygoms, siekta ji atsiimti. Vadinasi, Lietuvos ginkluotosios pajègos turèjo būti pasirengusios ne tik gynybiniam, bet ir puolamajam karui.

A. Gynybinis karas. Iš kaimyninių šalių tik Lenkija tuo metu buvo aiškiai agresyviai nusiteikusi prieš Lietuvą. Kitų kaimynių - Latvijos, Vokietijos ir Sovietų Sąjungos, nors jų pozicija ir nebuvo nustatyta formaliomis sutartimis, bet, turint omenyje bendrą politinę Rytų Europos konjunktūrą, tikètina, užpuolimo pavojus Lietuvai negrèsè. Vienintelè šalis, kuri grasino Lietuvai ginkluotu konfliktu, buvo Lenkija. Vadinasi, galima daryti išvadą, kad Lietuva turèjo būti visada pasirengusi gintis lenkų puolimo atveju.

Atsižvelgiant $\mathfrak{i}$ to meto Lenkijos kariuomenès dislokaciją, plk. ltn. K. Škirpos nuomone, jos puolimas galejo būti trejopas: 1) staigus, 2) jungtinèmis III korpuso pajègomis, kurios tuo metu buvo išmètytos visoje lenkų okupuotoje Lietuvos teritorijoje, ir 3) masinis (jame dalyvautų ne tik III korpuso, bet ir iš Lenkijos atsiųstos pastiprinimo pajègos). 


\section{I atvejis (staigus puolimas)}

Staigus puolimas galèjo ịvykti, jei lenkai būtų puolę lietuvius dar prieš peržengdami demarkacijos liniją, iš esmès nepergrupavę kariuomenès okupuotoje teritorijoje ir nepaskelbę mobilizacijos.

Tokiame Lietuvos puolime pirmiausia galètų dalyvauti arti demarkacijos linijos esančios Lenkijos kariuomenès dalys:

a) lenkų pasienio apsaugos batalionai ir eskadronai, tuo metu stovintys prie demarkacijos linijos;

b) Vilniaus ir Suvalkų rajonuose dislokuotos pajėgos;

c) Gardino igula, kuri šiuo atveju sudarytų atsargą.

Tokio staigaus puolimo galimos kryptys: Vilnius-Ukmerge, VilniusKaišiadorys ir Suvalkai-Marijampole.

Lietuvių uždavinys šio staigaus puolimo atveju - sulaikyti priešo veržimąsi i Lietuvos teritorijos gilumą, siekiant sudaryti galimybę kariuomenei mobilizuotis. Praktiškai reikètų užstoti tas pajègas arba kryptis, kurias priešas pasirinktų savo puolimui vykdyti.

Čia buvo iškilę 3 klausimai:

1. Kokio dydžio turètų būti Lietuvos pajegos, kurioms būtų keliamas uždavinys pridengti lietuvių mobilizaciją staigaus priešo puolimo atveju?

2. Kokioje vietoje ar vietose jos turètų susitelkti ir veikti?

3. Kaip greitai jos turètų būti sutelktos tose vietose? ${ }^{79}$

Plk. ltn. K. Škirpos teigimu, krašto pajègų, skiriamų mobilizacijai dengti, dydis priklausytų nuo to, kokiomis pajègomis priešas Lietuvą staigiai pultų. Tačiau galima tik spèlioti, kuriomis puolimo kryptimis Vilnius-Ukmergè ar Vilnius-Kaišiadorys, ar abiem iš karto - veržiantis galètų dalyvauti Lenkijos kariuomenès dalys, tuo metu esančios Vilniaus rajone:

I legionų divizija: 1-asis, 5-asis ir 6-asis pèstininkų pulkai bei vienas lengvosios artilerijos pulkas - Vilniuje;

XIX péstininkų divizijos: 85 -asis pèstininkų pulkas ir vienas 13-ojo artilerijos pulko divizionas - Naujojoje Vilnioje;

3-ioji kavalerijos brigada: 4-asis ulonų pulkas - Pabradeje; 23-iasis ulonų pulkas ir raitosios artilerijos 3-iasis divizionas - Vilniuje; 13-asis

Ten pat, 1. 150-153. 
ulonų pulkas - Naujojoje Vilnioje, 3-iasis sunkiosios (korpuso) lauko artilerijos pulkas - Vilniuje. Faktiškai galejjo būti apie 10000 žmonių.

Šiuo atveju prie šio skaičiaus reikètų prideti 77-ojo pėstininkų pulko apie 1900 ir 19-ojo artilerijos pulko 3-iojo diviziono apie 250 karių, kurie buvo Lydoje ir lietuvių nepastebėti galèjo būti atvežti ị Vilnių.

Suvalkų-Marijampolès kryptimi vykstančiame staigiame puolime galejjo dalyvauti Suvalkų igulos kariuomenè: 41-asis pėstininkų pulkas, 29-ojo lengvosios artilerijos pulko vienas divizionas, 2-asis ulonų pulkas, 3 -iasis raitųjų šaulių pulkas ir raitosios artilerijos 4-asis divizionas. Taigi būtų susidarę: péstijos - apie 1300 , artilerijos - apie 900, kavalerijos apie 1 700, iš viso apie 4000 karių. O prie šio skaičiaus dar būtų galima pridèti Augustave buvusi 1-ąji ulonų pulką - apie 700 karių.

Gardino iguloje buvo daugiau kaip 3000 karių.

Taigi staigiame puolime, neskaitant Gardino igulos, galejjo dalyvauti apie 14000 karių ir dar visi pasienio batalionai ${ }^{80}$.

Norint sutrukdyti tokių pajègų puolimą, lietuviams reikejjo turèti nors 2/3 dydžio pajègas, t. y. apie 10000 karių, kitaip sakant, vieną visos sudèties diviziją.

Sugrupuotas Lietuvos pajègas staigiam priešo puolimui atremti buvo galima sutelkti arčiau prie tuometès demarkacijos linijos, neleidžiant jam nuniokoti né vienos pẻdos mūsų žemès. Todèl kilo klausimas: ar pakaks laiko turimoms pajègoms sutelkti prie demarkacijos linijos kuria nors viena iš trijų minètų krypčių pirmiau, negu priešas ją peržengs?

Šiuo atveju viskas būtų priklausę nuo priešo veiksmų greičio ir staigumo. Todèl reikejjo išsiaiškinti, kaip staigus lenkų pajègų puolimas galètu vykti. Norẻdami staigiai pulti, jie negalètų iš anksto tam pasiruošti neatskleidę paslapties. Kitaip sakant, negalètų vykdyti mobilizacijos, papildyti kariuomenès dalių, jų pergrupuoti, aprūpinti karo meto gurguolèmis ir t. t. Jeigu lenkai prieš puolimą viso to nedarytų, apie puolimą lietuviai sužinotų tik tada, kai Lenkijos pajègų priešakinès dalys peržengtų demarkacijos liniją. Iš to tektų daryti išvadą, jog staigaus priešo puolimo paralyžiuoti Lietuvos pajẻgoms greičiausiai nepavyktų, nes neužtektų laiko susitelkti prie pat demarkacijos linijos. Kur tada jas būtų galima surinkti? Atsakymas vienas - ten, kur priešas negalètų atsidurti pirmiau negu pasiruošusios kautynėms Lietuvos pajègos. Šiuo atveju galimi

80 Ten pat. 
pajègų susitelkimo rajonai:

a) pirmajai krypčiai dengti - Jonavos-Ukmergès linija;

b) antrajai krypčiai dengti - Kaišiadorių rajonas;

c) trečiajai krypčiai dengti - Marijampolès rajonas.

Be to, reikejo, kad:

a) šioms kryptims dengti jau taikos metu minètuose rajonuose būtų nors dalis mobilizacijos priedangai skirtų pajègų;

b) demarkacijos linija būtų uždaryta pasienio apsaugos dalių, kai tik taps aišku, kad karinis konfliktas galimas.

Kaip greitai netikètam priešo puolimui paralyžiuoti skirtas pajègas reikètų sutelkti nurodytuose rajonuose?

Tai priklausytų nuo dviejų veiksnių:

a) nuo to, kada priešas galètų, ịprastu tempu žygiuodamas, pasiekti lietuvių numatytą susitelkimo rajoną ir gynybos pozicijas;

b) kaip greitai Lietuvos pajègos sugebètų susitelkti priešo puolimo kryptimis.

Papildomos sąlygos:

a) eidamas pirmąja kryptimi nuo demarkacijos linijos iki Šventosios upès, priešas turètų ịveikti $30 \mathrm{~km}$, vadinasi, tam skirti daugiau kaip vieną dieną;

b) judančiam antrąa kryptimi nuo demarkacijos linijos iki Kaišiadorių priešui reikètų íveikti $32 \mathrm{~km}$ ir sugaišti daugiau kaip parą;

c) eidamas trečiąja kryptimi nuo demarkacijos linijos iki Marijampolès, priešas $34 \mathrm{~km}$ įveikti turètų skirti taip pat daugiau kaip parą.

Vadinasi, lietuvių mobilizaciją dengiančios pajėgos staigaus puolimo atveju privalèjo būti vietoje ne vèliau kaip antros konflikto dienos rytą, t. y. palyginti labai greitai, kad turètų dar šiek tiek laiko susitvarkyti. Galima net suabejoti, ar per tiek mažai laiko galimomis puolimo kryptimis būtų spèta sutelkti turimas, nors ir nedideles, Lietuvos pajègas.

Iš viso to aiškejjo, kad Lietuvos pajègų intervencija siekiant užkirsti kelią priešo staigiam puolimui galejjo prasidèti ne anksčiau kaip antrą dieną, lenkams peržengus demarkacijos liniją. Anksčiau mobilizaciją dengiančiomis kryptimis lietuviai galejo pasiųsti tik kavaleriją ir atskiras pėstininkų dalis, kurios jau taikos metu buvo Ukmergèje ir Marijampoleje.

Neitgyvendinę minètų priemonių, lietuviai būtų buvę bejègiai nesugebètų nors kiek veiksmingiau dengti mobilizacijos. 
Plk. ltn. K. Škirpos teigimu, nustatant ankstesnę kariuomenès organizaciją, nebuvo rimtai įvertinta staigaus lenkų puolimo galimybė. Todèl nustatant naujus organizacijos dèsnius reikèjo būtinai $\mathfrak{i}$ tai atsižvelgti. Taikos metu turèjo būti numatytos mobilizacijai dengti pakankamai gausios pajėgos ir dislokuotos taip, kad galètų laiku išsidèstyti atitinkamuose rajonuose pagrindinemis lenkų puolimo kryptimis ${ }^{81}$.

II atvejis (lenkų puolimas mobilizuotomis III korpuso pajègomis)

Okupuotoje Lietuvos teritorijos dalyje aptariamuoju laikotarpiu lenkai turèjo vieną kariuomenès korpusą (III), kurị sudarè trys pèstininkų divizijos (I, XIX ir XXIX). Be to, tam korpusui buvo priskirta 3-ioji atskiroji kavalerijos brigada (iš trijų kavalerijos pulkų), jo rajone buvo I kavalerijos divizijos dalys (4-oji kavalerijos brigada, susidedanti iš dviejų kavalerijos pulkų). Turimomis žiniomis, III korpuse faktiškai buvo apie 30000 žmonių. Šios pajègos buvo išmètytos po visą Vilniaus-Gardino sritị.

Norèdami pulti jungtinèmis pajègomis (pagal karo principus), lenkai turejo sutelkti visas III korpuso dalis vienoje vietoje arba keliose išeities ir susitelkimo zonose, o po to jau veikti. Bet koks lenkų pajègu grupavimas pareikalautų keleto dienų ir negalètų likti lietuvių žvalgybos nepastebètas.

Pastebejjus lenkų parengiamuosius puolimui veiksmus - kariuomenès dalių perkèlimą arčiau demarkacijos linijos - reikètų tuojau skelbti mobilizaciją ir uždaryti sieną. Iš karto kiltų klausimas, per kiek laiko lietuviai turètų atlikti mobilizaciją ir suspèti mobilizuotas dalis pervežti ị kariuomenès susirinkimo ir susitelkimo rajoną. Tą laiką galima nustatyti pagal lenkų parengiamuosius puolimui veiksmus. Tokiu atveju lenkai turètu savo kariuomenès dalis papildyti iki karo meto sudèties (etatų), aprūpinti jas reikalingomis gurguolèmis, sukurti operacijoje dalyvaujančiai armijai tiekimo ir aprūpinimo aparatą.

Nors visa tai taikos metu ir būtų puikiausiai atlikta, geriausiu atveju lenkams prireiktų maždaug 3 dienų. Papildytų dalių permetimas arčiau demarkacijos linijos pareikalautu antra tiek laiko. Pagaliau (blogiausiu atveju), siekdami turèti daugiau laiko, lietuviai galètų, rengdamiesi pajègų sutelkimui, savo kariuomenès dalims parinkti zoną ne prie demarkacijos linijos, o per vieną ar du etapus toliau nuo jos ir tikètis laimèti apie 5-7

${ }^{81}$ Ten pat, 1. 154-155. 
dienas. Jie turètų savo ginkluotụjų pajègų organizaciją sutvarkyti taip, kad per tą laiką būtų galima atlikti savo kariuomenès mobilizaciją, pervežti ją i sutelkimo zoną ir parengti kautynèms.

Kitas klausimas - kiek reikètų mobilizuoti pajègų, norint sulaikyti lenkų puolimą, jei šie ji vykdytų vien III korpuso jegomis? Vadovaujantis karo istorijos patirtimi, lietuviai turètų šiam tikslui mobilizuoti tiek žmonių, kad Lietuvos kariuomenė sudarytų nors $2 / 3$ priešo pajègų. Kitaip sakant, reikèjo turèti ne mažiau kaip 3 karo meto sudèties divizijas, atitinkamas artilerijos, kavalerijos, aviacijos ir kitų specialiụjų ginklų rūšių pajègas. Kaip matyti, viskas būtų priklausę nuo laiko. Galima tvirtinti, jog, per numatytą laiką atlikus mobilizaciją ir kariuomenès sutelkimą galima lenkų puolimo kryptimi, būtų nemažai galimybių laimèti. Todèl Lietuvos kariuomenès organizacija turèjo būti taip sutvarkyta, kad savo pajègų mobilizaciją ir sutelkimą galètų atlikti per 5-6 dienas ${ }^{82}$.

III atvejis (masinis puolimas, kuriame dalyvautu ne tik III korpuso dalys, bet ir iš Lenkijos gilumos atgabentos jų pajegos)

Šiuo atveju Lenkijos ir Lietuvos ginkluotųjų pajègų santykis galèjo būti dvigubai ar daugiau kartų palankesnis lenkams. Lenkijos didelių pajègų sutelkimas prieš Lietuvą jokiu būdu nebūtų slaptas ir greitas, todèl lietuviai galètų savo kariuomenę tinkamai mobilizuoti ir sutelkti. Tačiau šios Lietuvos pajègos būtų per mažos lenkų puolimui sulaikyti. Iškèlę uždavinị žūtbūt tai padaryti, lietuviai savo nedidelę kariuomenę pasmerktų lemiamai kovai iš anksto žinodami, jog beveik neturi galimybių jos laimèti. Tai būtų nusikaltimas, nes jau pirmame mūšyje Lietuvos kariuomenę priešas sunaikintų, o be jos niekas su Lietuva nebesiskaitytų.

Kaip reikia elgtis, kad to neatsitiktų?

Plk. ltn. K. Škirpos nuomone, tokiomis aplinkybèmis iš Lietuvos kariuomenés neturètų būti reikalaujama to, ko ji nepajẻgtų atlikti. Esant tokiam pajègų santykiui, kokị turime omenyje (dvigubą ar dar didesnị lenkų naudai), Lietuvos kariuomenei galima būtų kelti tik šiuos uždavinius: neprovokuoti lemiamo mūšio, stengtis trukdyti priešui veržtis toliau, siekiant laimèti kuo daugiau laiko ir taupant savo jègas.

Kariuomenei uždavinys galèjo būti suformuluotas kaip gynyba manevru, šiuolaikinëje strategijoje vadinama "gynyba traukiantis“. Šiam manevrui atlikti būtinai reikèjo turèti atitinkamą skaičių divizijų, kad

${ }^{82}$ Ten pat, 1. 156-157. 
būtų galima sudaryti strateginę gilumą. Atsižvelgiant ị karo veiksmų teatrą ir vietoves ypatybes, Lietuvai reikejo turèti 6 divizijas. Tomis dienomis kariuomenè manevruodama galètų išsilaikyti daugiau kaip mėnesị. Gynybos manevrą būtų galima vykdyti ir turint 4 divizijas, pakankamai stiprią kavaleriją sparnuose. Tačiau tiek mažai divizijų būtų greitai pavargusios.

Per tą laiką, kurị mūsų artilerija laimètų, Užsienio reikalų ministerija gal galètų gauti kitų Lietuvai draugiškų valstybių paramą ir padaryti tai, kas reikia, norint išvengti visiško ir galutinio pralaimejjimo. Taip manevruodama Lietuvos kariuomené trauktųsi i savo atsargines pozicijas, kad papildytų ir sustiprintų gretas. O priešas, veikdamas svetimoje teritorijoje, toli nuo savo bazių, būtų priverstas, be nuostolių, kuriuos patyrè dèl lietuvių aktyvių veiksmų, daug savo pajègų išsklaidyti ịvairiuose miesteliuose ir igulose okupacinei tvarkai palaikyti. Transporto priemones, geležinkelius, kelius, tiltus ir kitą karo turtą ir išteklius traukdamasi atgal Lietuvos kariuomenè turètų sunaikinti, kad priešas tuo negalètų pasinaudoti.

Be to, priešo užnugaryje galima suaktyvinti partizanų veiklą, kuriai sąlygos (bent iš dalies) tam tikrose zonose būtų sudarytos jau taikos metu.

Visa tai per tam tikrą laiką galètų tiek susilpninti okupacines priešo pajègas, kad jų santykis pasikeistų lietuvių naudai. Tuomet atsirastų galimybių pereiti $\mathfrak{i}$ kontrpuolimą ir išvyti priešą iš Lietuvos teritorijos ${ }^{83}$.

B. Puolamasis karas. Jau anksčiau buvo minèta, jog, palankiai susiklosčius politinèms aplinkybèms, iš Lietuvos kariuomenès galèjo būti pareikalauta pabandyti išvaduoti iš lenkų jungo okupuotą šalies dalị. Kitaip sakant, lietuviai turèjo galvoje ir puolamojo karo galimybę. Iš to galima daryti išvadą, kad Lietuvos kariuomenés organizacija taip pat turejo atitikti puolamojo karo reikalavimus. Kokie gi tie reikalavimai?

a) Jei Lietuvos pajègoms kada nors tektų eiti vaduoti Vilniaus, šis žygis galètụ ỉvykti tik visiškai aiškiomis ir palankiomis politinemis aplinkybèmis ir būti trumpas, t. y. turètu greitai baigtis. Organizaciniam ir mobilizaciniam pasirengimui reikètų skirti tiek pat mažai laiko, kaip kad ir gynybinio karo atveju.

b) Puolamasis žygis turètų būti atliktas sutelkus kuo daugiau pajègų, kad, atsièmus Vilniaus teritoriją, galima būtų užtikrinti visišką jo priklausomybę Lietuvai. Turint omenyje faktinị Lietuvos ginkluotujjų

${ }^{83}$ Ten pat, l. 158. 
pajègų dydị, reikètų mobilizuoti visas 4 pėstininkų divizijas. Vadinasi, ir puolamajo karo metu, ir jam rengiantis Lietuvos ginkluotujų pajègu organizacija turètų būti labai lanksti ${ }^{84}$.

\section{Organizaciniai reikalavimai}

Lietuvos ginkluotųjų pajègų struktūrai keliami organizaciniai reikalavimai išplaukè iš minètų strateginių siekių - ji turèjo būti labai lanksti:

a) suteikti galimybę vadovybei apsaugoti mobilizaciją nuo galimo priešo staigaus puolimo. Dèl to dar taikos metu reikejjo turèti:

1. sienai (demarkacijos linijai) uždaryti skirtą apsaugą, kuri šiai misijai būtų parengta dar taikos metu ir galètų ją pradèti dengti iš karto, kai tik paaiškès pavojus;

2. užnugaryje sieną dengiančią apsaugą, sudarytą iš pakankamai didelių pajègų, pasirengusių laiku pradèti dengti ị šalies teritoriją besiveržiančio ir jau išvaikiusio sieną dengiančias dalis priešo kryptị.

Visa tai būtų mobilizacijos priedanga.

b) sudaryti galimybę taikos meto kariuomenę per 3-4 dienas išplèsti iki 4 karo meto divizijų, kurios turètų atitinkamas specialių ginklų rūšių dalis;

c) sudaryti galimybę, netrukdant didinti kariuomenès iki keturių divizijų, skirti reikalingus pastiprinimo vienetus ir juos siųsti į pagalbą mobilizaciją dengiančioms pajègoms;

d) atsiradus finansinių galimybių, ginkluotąsias pajègas, neardant jų organizacinès sistemos, padidinti iki 6 ir daugiau divizijų;

e) sudaryti galimybes kartu su kariuomene rengti jos atsargą ir piliečius bendrai partizaninei veiklai;

f) neturèti mobilizacijos sandèlių i pietryčius nuo linijos: žemutinis Nemunas iki Kauno, Neris iki Šventosios ir Šventoji, Ukmergè, kur tokio sandèlio taip pat neturètų bùti;

g) nereikalauti komplikuotos mobilizacijos sistemos ${ }^{85}$.

III. Finansinio pobūdžio reikalavimai

Lietuvos ginkluotųjų pajėgų organizacijai buvo keliami šie finansinio pobūdžio reikalavimai:

a) nesudaryti respublikai nepakeliamos naštos;

${ }^{84}$ Ten pat, 1. 159-160.

85 Ten pat. 
b) būti ekonomiškai, t. y. kuo mažiau lešų skirti administracijos reikalams;

c) sudaryti galimybę sutaupytomis lešomis ịsigyti kariuomenei reikalingų medžiaginių išteklių, ypač karo metui;

d) stengtis, kad tuometés sistemos keitimas ir perejimas prie naujos nepareikalautų per daug lěšų, t. y. neviršytų biudžeto.

Déstydamas šiuos samprotavimus Vyr. štabo viršininkas plk. ltn. K. Škirpa sąmoningai vengè analizuoti karinę ir politinę pagalbą, kurią galejo suteikti Lietuvai kaimynai. Jis aptare sunkiausią padètị - kad viena pati Lietuva, bent jau konflikto pradžioje (1-2 ménesius), turètų atsilaikyti prieš galingesni priešą. Taip keldamas klausimą plk. ltn. K. Škirpa tikèjosi gauti daugiau duomenų, patvirtinančių, kad problema sprendžiama remiantis ne kokiais nors spekuliaciniais ar kitais abejotinais motyvais. Suteikus kuriai nors kaimyninei šaliai karinę ar politinę pagalbą, Lietuvos padètis nebūtų pablogèjusi ${ }^{86}$.

\section{Siūloma ginkluotuju pajègu organizacija}

Plk. ltn. K. Škirpos teigimu, išdèstytus reikalavimus galètų atitikti tokia Lietuvos kariuomenès organizacija:

1. Taikos meto kariuomenès organizacija

Centrinès įstaigos turètų būti sumažintos proporcingai atitinkamos kariuomenès dydžiui.

Pèstija: 7 pèstininkų pulkai, iš jų 3 - sudaryti iš 3 batalionų - buvo skirti numatomai mobilizacijai dengti, 4 - sudaryti iš dviejų batalionų.

Artilerija: 3 artilerijos pulkai, kurių kiekvieną sudarè:

a) dvi artilerijos grupes, grupę - 2 baterijos (po 4 patrankas);

b) viena haubicų baterija (4 patrankos);

c) viena mokomoji grupé artilerijos puskarininkiams rengti.

Visos baterijos atleidžiamos nuo ūkio darbų. Artilerijos pulkuose sukuriami ūkio padaliniai (kaip pesstininkų pulkuose).

Kavalerija lieka tokio pat dydžio kaip aptariamuoju laikotarpiu, tik ìsteigiami eskadronuose kautynių skyriai.

Aviacija lieka tokia pat kaip aptariamuoju laikotarpiu, tik sumažinamas administracinis aparatas.

Technikos dalys. Technikos pulkas panaikinamas. Vietoj jo sukurti:

a) vieną pionierių batalioną iš 2 pionierių kuopų, vienos mokomosios

86 Ten pat, 1. 160-161. 
pionierių komandos ir pionierių dirbtuvių;

b) vieną ryšių batalioną iš 2 ryšių kuopų ir vienos mokomosios komandos;

c) vieną technikos batalioną, susidedantị iš automobilių kuopos ir geležinkelių kuopos.

Šarvuočiai:

a) šarvuočių rinktinę panaikinti;

b) šarvuotųjų traukinių batalioną išformuoti;

c) šarvuotųjų automobilių kuopą pavadinti automobilių būriu;

d) tankų batalioną pavadinti tankų kuopa.

Automobilių būrị ir tankų kuopą priskirti prie technikos bataliono.

2. Taikos meto kariuomenès dislokacija

Pèstija. Mobilizacijai dengti trijų batalionų pulkai: 1-asis pėstininkų pulkas - Ukmergèje, 5-asis pėstininkų pulkas - A. Panemunèje, 9-asis péstininkų pulkas - Marijampolejje; dviejų batalionų pulkai: 2-asis pėstininkų pulkas - Šančiuose, 4-asis pėstininkų pulkas - Panevėžyje, 8-asis pėstininkų pulkas - Šiauliuose, 7-asis pėstininkų pulkas Klaipèdoje. Minosvaidžių kuopa - Klaipėdoje.

Kavalerija. 1-asis husarų pulkas - Kaune, 2-asis ulonų pulkas - Alytuje. Mokomasis eskadronas - Marijampoleje.

Artilerija. 2-asis artilerijos pulkas - Kèdainiuose, 3-iasis artilerijos pulkas - Kaune, 4-asis artilerijos pulkas - Vilkaviškyje. Mokomoji grupé - A. Panemunèje.

Specialiosios dalys. Aviacija - Kaune, pionierių batalionas - Kaune, ryšių batalionas - Kaune, technikos batalionas - Kaune ${ }^{87}$.

V. Taikos meto kariuomenès perëjimas i karo padèti

Paskelbus mobilizaciją, iškart formuojama šios sudèties IV pėstininku divizija: trys pėstininkų pulkai, vienas artilerijos pulkas, vienas kavalerijos eskadronas, viena pionierių kuopa, viena ryšių kuopa ir užnugario dalys.

Be to, prie kariuomenès vadovybès dar formuojami: vienas pionierių batalionas, vienas ryšių batalionas, vienas geležinkelių batalionas ir keturi atsargos péstininkų batalionai, prie kiekvienos divizijos po vieną ${ }^{88}$.

87 Ten pat, 1. 162.

88 Vyr. štabo viršininkas gen. št. plk. ltn. K. Škirpa parengė vieną pirmųjų laikinųjų slaptų 
Pèstija. Mobilizacijai dengti trys pèstininkų pulkai per trumpiausią laiką papildomi iki karo meto etatų sudèties. Kartu suformuojamos sieną dengiančios dalys ir ją dengia. Kiti keturi pulkai (kiekvienas iš dviejų batalionų) sudaro lygiagrečius pulkus: kiekvienas būrys pergrupuojamas $\mathfrak{i}$ kuopą, kuopa - $\mathfrak{i}$ batalioną, batalionas virsta pulku. Taip vietoje 4 taikos meto pulkų būtų suformuoti 8 karo meto pulkai, o iš viso (pridejjus mobilizaciją dengiančius pulkus) - 11 pulkų. Tačiau keturioms divizijoms reikès 12 pulkų. Taigi, trūktų dar vieno, kurị galima būtų sudaryti iš 3 pulkų mokomųjų kuopų, o kitų 4 pulkų mokomosios kuopos teiktų kadrus atsargos batalionams.

Minètos lygiagrečios dalys (pulkai) būtų formuojami Kaune, Panevèžyje, Šiauliuose ir Klaipėdoje. Šiose vietose reikètų turèti mobilizacijos sandèlius.

Kavalerija. Paskelbus mobilizaciją, kavalerijos dalys pasipildytų iki karo meto etatų. Mokomasis eskadronas būtų performuotas ị pulką.

Artilerija. Kaip ir kavalerija, artilerija būtų papildyta iki karo meto etatų. Mokomoji grupé - performuota i 4-ąj artilerijos pulką.

Pionieriai. Pionierių batalionas turètų iš viso suformuoti kiekvienai divizijai po vieną pionierių kuopą, o armijai - vieną pionierių batalioną. Šias pionierių dalis galima būtų sudaryti tokiu būdu: viena pionierių kuopa (taikos metu) būtų paruošta priskirti prie mobilizaciją dengiančių dalių. Ji pasipildytų iki karo meto etatų. Kita pionierių kuopa sudarytų 3 kuopas: kiekvienas būrys suformuotų po kuopą. Taip susidarytų 4 pionierių kuopos, o pionierių batalionas, reikalingas vadovybei, būtų suformuotas šiek tiek vèliau iš mokomosios pionierių kuopos karių.

Ryšių dalys. Paskelbus mobilizaciją, ryšių batalionas tokiu pat būdu kaip ir pionierių batalionas formuotų šias dalis: keturioms divizijoms po ryšių kuopą, vadovybei - vieną ryšių batalioną.

Geležinkelių dalys. Geležinkelių batalionas būtų sudarytas iš geležinkelių kuopos. Paskelbus mobilizaciją, būtų parengiami ir šarvuotieji traukiniai.

Automobilių dalys. Automobilių kuopa būtų išplèsta iki automobilių bataliono. Tankų kuopa ir šarvuotųjų automobilių būrys - papildyti

mobilizacijos instrukcijų (M-2) karo apygardų štabams ir karo sričių viršininkams. Ši instrukcija krašto apsaugos ministro plk. ltn. J. Papečkio buvo patvirtinta $1926 \mathrm{~m}$. liepos 19 d., LCVA, f. 929 , ap. 3, b. 432, 1. 32-53. 
iki karo meto etatų.

Aviacija. Padidinama iki karo meto etatų ${ }^{89}$.

Iš anksčiau pateiktų plk. ltn. K. Škirpos samprotavimų matyti, jog naujasis Vyr. štabas objektyviai vertino tuometę Lietuvos ir jos kariuomenès padètị, pagrindè motyvus, kurie vertè peržiūrèti jos organizaciją, smulkiai išaiškino strateginio, organizacinio ir finansinio pobūdžio reikalavimus, kuriuos turejo atitikti to meto krašto ginkluotosios pajègos, pateike jų taikos ir karo meto dislokacijos projektą.

Tą pačią liepos 27 d. Vyr. štabas slaptame rašte karo apygardų viršininkams nurodè, jog, siekiant kuo geriau pasirengti karui, be kita ko, reikia iš anksto žinoti, kokie elementai galètų turèti ịtakos organizuojant ir plètojant galimus ginkluotus susirèmimus.

Tarp šių elementų pirmiausia išskirtinos vietos sąlygos, todèl ị ši nurodymą - nuolat studijuoti taktinès reikšmès vietos ypatybes - buvo atkreiptas visų karo apygardų viršininkų dèmesys. Tuo tikslu reikejjo organizuoti rekognoskuotes, tačiau jų užduotys priklausè nuo vietos sąlygų, todèl visa tai buvo palikta tvarkyti kiekvienam apygardos viršininkui individualiai ${ }^{90}$.

Minètiems plk. ltn. K. Škirpos dokumentų projektams po kelių posèdžių pritarė Krašto gynimo taryba, kuriai pirmininkavo Prezidentas K. Grinius. Prasidejo intensyvus darbas. I jị i̊sitraukè visi Vyr. štabo karininkai. Dar po poros mènesių buvo parengtas išsamus Lietuvos Respublikos ginkluotujų pajėgų koncentracijos planas karui su lenkais. Jị sudarè dvi dalys: 1) žinios apie Lenkiją ir 2) Lietuvos padètis.

Pirmąją dalị sudare 4 skyriai. Pirmajame buvo pabrèžta, jog lenkų veikimo būdai galimo karo su Lietuva atveju remsis: a) bendrais tautiniais ir valstybiniais siekiais, b) jų valstybės politine, ekonomine, socialine ir dvasine padètimi, c) karinèmis pajègomis, kurias būtų galima nukreipti prieš Lietuvą, ir karinèmis galimybėmis, kurias lems Lietuvos karinè padètis ir tuo metu susiklosčiusios, taip pat ir vietos, aplinkybès.

Antrajame skyriuje buvo apibūdinti Lenkijos siekiai Lietuvos atžvilgiu: a) sudaryti tinkamas sąlygas tautinei ekspansijai ị Lietuvos teritoriją,

\footnotetext{
89 Ten pat, 1. 163-164.

90 Vyr. štabo viršininko plk. ltn. K. Škirpos 19260727 slaptas raštas Nr. 20963 I, II ir III karo apygardų viršininkams, LCVA, f. 510, ap. 1, b. 101, 1. 3-5.
} 
b) turèti patogesni priejjimą prie Baltijos jūros, c) užimti kelius, einančius iš Sovietų Sąjungos ị Vakarų Europą, d) užtikrinti platesnę rinką savo pramonès gaminiams.

Trečiajame skyriuje apibūdinta Lenkijos valstybės tarptautinè ir vidaus padėtis, karinès pajègos. Kaimyninèje lenkų III karo apygardoje buvo devyni pėstininkų, aštuoni kavalerijos, trys lengvosios artilerijos ir maždaug trys raitosios artilerijos pulkai, vienas sunkiosios artilerijos ir vienas pionierių pulkas, vienas automobilių, vienas gurguolès, vienas žandarmerijos divizionas, vienas sanitarijos batalionas, viena dviratininkų kuopa. Iš viso III karo apygardoje buvo apie 31000 kovotojų, jai priklausè 10464 arkliai $^{91}$. Vien šios lenkų karo apygardos pajėgos buvo pakankamos, kad lietuvius užkluptų nelaukdamos savo mobilizacijos pabaigos ir nepaliktų laiko jiems mobilizuotis. Be to, Lenkija turejjo karo laivyną, kuris galèjo sẻkmingai blokuoti Lietuvos pajūrị.

Be judriụjų karo pajėgų, Lenkija turèjo ịsirengusi nuolatinius įtvirtinimus. Lietuviams buvo svarbūs Gardinas ir Vilnius - išeities ir atramos punktai Lietuvos karo teatre vykdomų operacijų metu, iš dalies saugantys ir lenkų komunikacijų linijas.

Pažymėtina dar viena lietuviams svarbi III karo apygardos susisiekimo kelių ypatybė: kilus Lenkijos ir Sovietų Sąjungos karui, lenkai būtų dėję visas pastangas, kad paimtų í savo rankas geležinkelị ir kelius Augustavas-Suvalkai-Šeštokai-Kaunas-Vilnius, nepaisydami lietuvių ginkluoto pasipriešinimo. Tokiu atveju lenkų smūgis iš Suvalkų Kauno kryptimi galëjo ịgyti ypatingą svarbą.

Apskritai Lenkijos siekiai vertė juos pasirinkti puolamąji karą, o turimos priemonès leido taip kariauti ${ }^{92}$.

Ketvirtajame skyriuje plačiai aptarti lenkų galimo puolimo patogiausi būdai ir kryptys pabrèžiant, jog galutinis jų karo su lietuviais tikslas užimti visą Lietuvos teritoriją ir sudaryti sąlygas, kuriomis karinis užèmimas virstų politiniu jos prijungimu. Šiems tikslams pasiekti reikejo keleto dalykų: sumušti Lietuvos kariuomenę ir paveikti jos valdžią bei visuomenę taip, kad jos de facto pripažintų, jog tolesnis pasipriešinimas yra negalimas. Šių dviejų priemonių suderinimas turèjo laiduoti galutinę

${ }_{91}$ Lietuvos Respublikos ginkluotujų pajègų koncentracijos planas karui su lenkais, LCVA, f. 929 , ap. 3, b. 538, 1. 89-92.

92 Ten pat, 1. 93-94. 
pergalę ekonomiškiausiu būdu. Praktiškai tam reikèjo:

1) sunaikinti didesnę dalị Lietuvos kariuomenès, neleisti per trumpą laiką jai pasipildyti ir užimti patogesnes gynybos pozicijas;

2) užimti svarbesnius išteklių sutelkimo ir administracinius centrus;

3) nutraukti susisiekimą, ryšius tarp ịvairių sričių ir užkirsti kelią i užsienị;

4) visa tai atlikti per trumpiausią laiką, taupant savo jègas, netikètai užklupti lietuvius ir neleisti pasikeisti politinei situacijai jų naudai.

Trumpai tariant, lenkai planavo pasirinkti tinkamą puolimo krypti, momentą ir pajègas.

Galimo lenkų puolimo kryptys. Savo tikslams pasiekti lenkams labiausiai tiko pulti Kauną, o po to ir Klaipèdą. Pasiekti Kauną jie galejjo puldami trimis kryptimis:

- iš rytų - išilgai geležinkelio Vilnius-Kaunas linijos;

- iš pietų - per Suvalkiją;

- išilgai Neries (ị šiaurę nuo jos).

Pirmoji iš šių krypčių buvo trumpiausia $(66 \mathrm{~km})$, bet lenkai būtų priversti Kauną frontaliai atakuoti. Tokia ataka galejo pareikalauti daug aukų ir ilgai užsitęsti. Be to, čia pasiekta pergalè nebūtų užtikrinusi lemiamų rezultatų, nes lietuviai tada trauktųsi Žemaitijos ir Klaipėdos krašto bazių link. Sèkmingą puolimą šia kryptimi galèjo apsunkinti kliūtys - Nemuno ir Neries upès. Be to, čia puolančioms lenkų pajègoms, tikètina, grèstų lietuvių smūgiai iš Jonavos, Veprių ir Ukmergès ruožo. Tokiu atveju jie būtų priversti gan didelę kariuomenès dalị skirti savo dešiniajam sparnui apsaugoti. Šios pajègos turètų atlaikyti ir galimą minèto ruožo lietuvių puolimą.

Antroji galima lenkų puolimo kryptis buvo ilgesnè (84 km). Veikdami šia kryptimi, jie galejo nutraukti lietuvių susisiekimą su Vokietija per Virbalị. Kauno atakuojamas sektorius buvo šiek tiek silpniau parengtas gintis, bet Nemunas - tolesni puolimą stabdanti kliūtis - jị sustiprino. Be to, Lenkijos kariuomenès puolimas šia kryptimi nebūtų labai suvaržęs lietuvių veiksmų laisvès ir privertęs apsaugoti Vilniaus kryptị. Veikdami Kauno kryptimi, lenkai galejjo šị miestą blokuoti, o pagrindinị smūgị nukreipti Žemaitijos, pavyzdžiui, Raseinių link. Bet ir šiuo atveju Nemunas jiems būtų rimta kliūtis.

Pagrindinė Lenkijos kariuomenès smūgio kryptis per Veprius, Jonavą būtų vedusi prie svarbiausios Lietuvos komunikacijų linijos Jonava- 
Šiauliai. Tai buvo sritis, kur Lenkijos pajègos galèjo rasti daug palankių jai gyventojų.

Puolimas šia kryptimi buvo ypatingas tuo, kad, lenkams užemus Jonavą, Lietuvos kariuomenè galèjo atsidurti vienoje iš šių padéčių:

1) Lietuviams susitelkus Kaune, šis miestas būtų likęs be geležinkelio. Jei Lietuvos kariuomene ilgiau būtų buvusi Kaune, jos atsitraukimo kelius i Žemaitiją lenkai galèjo atkirsti, o pajeggas apsupti ir priversti gintis tvirtovès rajone. Lenkai būtų turèję visiškai laisvas rankas ir mėginti užimti Kauną jèga, pasirinkę patogiausią kryptị, ar apgulti jị mažesnèmis pajègomis, o su kitomis - užimti likusį Lietuvos teritorijos plotą, kovodami su čia likusiomis improvizuotomis pajègomis. Tokioje padètyje Kaunas dèl moralinių ir materialinių priežasčių ilgalaikès priešo apgulos nebūtų sugebėjęs atlaikyti.

2) Jei Lietuvos kariuomenè būtų sutelkta Kauno rajone, o lenkams pavyktų užimti Jonavą, Kaune palikus mažesnes pajègas, o daugumą jų panaudojus Jonavos-Raseinių krypčiai ginti, Lenkijos kariuomenè iškart užvaldytų geležinkelį Jonava-Šiauliai. Kauno gynyba šaliai būtų reikšminga tol, kol Lietuvos kariuomene, lenkų stumiama iš rytų, neperžengtų Nevėžio. Toliau ryšys su Kaunu nutrūktų ir jo gynyba taptų vietinès reikšmės.

3) Lietuviams savo pagrindines pajègas sutelkus Jonavos-Veprių rajone, lenkams tektų su jomis susidurti i šiaurę nuo Neries. Šiuo atveju, jei nebūtų padaryta taktinių klaidų, lietuviai galètų pasirinkti atsitraukimo kryptị $\mathfrak{i}$ vakarus, o prireikus - ir Kauno link.

Taigi, Vyr. štabo nuomone, galimo lenkų puolimo reikejjo tikètis šiomis pagrindinemis kryptimis:

1) Vilnius-Vepriai-Jonava ar Kèdainiai;

2) Vilnius-Kaišiadorys-Kaunas;

3) Suvalkai-Marijampolè-Kaunas.

Pirmoji iš jų geriausiai tiko galutiniams rezultatams pasiekti. Tačiau kartu neatmesta galimybè, kad Lenkijos pajègos galejo veikti ir antrąa ar trečiąja kryptimi. Taigi reikèjo manyti, jog lenkai, pasirinkę kurią nors vieną iš jų kaip pagrindinę, kitas laikys ne tokiomis svarbiomis ir jomis stums ị Lietuvos teritoriją silpnesnes pajegas.

Be minètų krypčiu, buvo laikomos galimomis lenkų atskirų grupiụ veikimo Švenčionių-Anykščių-Panevež̌io kryptys. Tai būtų leidę jiems prasiskverbti toliausiai $\mathfrak{i}$ Lietuvos užnugarị ir jị dezorganizuoti. 
Galų gale dèl pavojaus geležinkeliui Gardinas-Vilnius Varėnos ruože Lenkijos kariuomene turètų skirti tam tikrą dali pajégų jam saugoti. Jų uždavinys būtų neutralizuoti lietuvių Alytaus igulą. Suvalkijoje sèkmingai vykstant veiksmams, ši Lenkijos kariuomenès dalis galèjo, judèdama išilgai Nemuno, dalyvauti bendrame Kauno puolime. Iš tuomečio Lenkijos pajėgų išsidèstymo buvo galima spèti, kad tokią grupę sudarytų Gardino igulos dalys. Todèl lietuvių uždavinys buvo neleisti nė vienai iš šiu grupių sẻkmingai veikti, kad nebūtų pakenkta Lietuvos gynybos sistemai ${ }^{93}$.

Kaip minèta, to meto Lenkijos valdančiụjų sluoksnių politika buvo nukreipta prieš Lietuvą, t. y. agresyvi. Dèl politinių priežasčių planuota sumušti Lietuvos kariuomenę. Puolimą surengti tada, kai, susidūrus su jos pajėgomis, jègų santykis bus Lenkijos kariuomenès naudai. Lenkai jau taikos metu savo pajègas buvo išdèstę rajonuose, kuriuos reikèjo laikyti sutelkimo vietomis, o Lietuvoje dar būtų reikeję atlikti mobilizuotų dalių perkèlimą iš taikos meto stovyklụ i sutelkimo vietas. Jei jẻgų santykis būtų pakrypęs lietuvių naudai, ị III karo apygardą galëjo atvykti papildomos pajègos iš kitų Lenkijos sričių. Tam galëjo sukliudyti tik kitų šalių intervencija. Todèl, rengiantis karui su lenkais, pirmiausia reikejo turèti galvoje jų galimybę pulti Lietuvą nuo pat pirmosios faktinio karo dienos. Bendros politinès sąlygos šiam lenkų puolimui tuo metu buvo palankios ${ }^{94}$.

Lietuvos ginkluotųjų pajęgų koncentracijos plano karui su lenkais antroji dalis buvo skirta krašto padéčiai aptarti. Ją sudaré keturi skyriai. Pirmajame pabrèžiama, kad lietuvių galimybès karo su Lenkija atveju priklauso nuo:

a) valstybės siekių;

b) šalies tarptautinès padèties;

c) šalies vidaus padèties;

d) karui pasirengusių pajègų kiekio, kokybès, vietos ir laiko;

e) politinių ir operatyvinių aplinkybių karo pradžioje.

Visus šiuos veiksnius reikèjo įvertinti turint galvoje Lenkijos galimybes.

Antrajame plano skyriuje Lietuvos valstybès siekiai Lenkijos atžvilgiu buvo:

a) išlaikyti visišką valstybės nepriklausomybę (tuometès teritorijos);

93 Ten pat, 1. 95-96.

94 Ten pat, 1. 98. 
b) atsiimti iš lenkų okupuotą kraštą su Vilniumi ${ }^{95}$.

Trečiajame skyriuje apžvelgta ir įvertinta to meto Lietuvos tarptautinè padètis. Būdama maža valstybè, ji siekè išlaikyti tam tikrą politiniu santykių pusiausvyrą tarp didžiųjų kaimyninių valstybių - Lenkijos, Vokietijos ir Sovietų Sąjungos. Atsižvelgdama ị tai, privalèjo būti nuolat pasirengusi ginkluotam konfliktui su bet kuria iš jų, šiai pusiausvyrai sutrikus. Tuo metu pavojingiausia valstybe buvo laikoma Lenkija, nes ji siekè pasisavinti Lietuvos teritoriją.

Nors Lietuva buvo Tautų Sąungos narè, tuometė praktika rodo, jog ji negalejo pasitikèti šios Sajungos pakto nei 10-uoju straipsniu, kuris laidavo Sąjungos nariams pagalbą užpuolimo metu, nei 11-17 straipsniais, varžančiais karo veiksmų pradžią. Pažymėtina, jog teisinès normos tuo metu Lietuvai neturèjo didelès reikšmès ir dèl to, kad lenkai galèjo savaip aiškinti savo ir lietuvių santykius. Lietuvos santykiai su kitomis valstybėmis nedavè pagrindo tikètis paramos. Stokota diplomatinių aktų, kuriais Lietuvai būtų užtikrinta svetimų valstybių pagalba karo atveju. Tokia padètis labai priklause ir nuo Lietuvos tuo metu sudaryto nedidelio verslo kontrahento.

Vyr. štabe vyravo nuomoné, jog: a) visiškai pakanka duomenų, kad būtų galima laukti lenku puolimo, b) Lietuvos politikai karui su lenkais nepasiruošę, nes neturi jokių tikrų duomenų, kurie leistų tikètis kitų valstybių pagalbos ar kliudytų tokią pagalbą suteikti Lenkijai.

Be to, nebuvo ko laukti ir iš mūsų diplomatijos - nei perspejjimo, kad karas gali kilti, nei nurodyto laiko, kada, prasidejjus karui, galima būtų laukti išorès pagalbos. Prieita prie išvados - būtina visą laiką būti pasirengusiems karui ir iš savo planų išbraukti viską, kas galètų trukdyti organizuoti Lietuvos ilgalaikę gynybą ${ }^{96}$.

Koncentracijos plano antrosios dalies ketvirtajame skyriuje itin daug vietos skirta šalies vidaus padèčiai aptarti. Pirmiausia, remiantis Nepriklausomybès kovų patirtimi, tikètasi, kad Lietuva, tinkamai pasirengusi, galès karo atveju mobilizuoti apie $8-10$ proc. visų šalies gyventojų, t. y. apie 180 000-220 000 žmonių. Tam reikejjo iš anksto tinkamai pasiruošti.

Lietuvos ekonominè padètis buvo svarbi tiek, kiek eventualaus karo atveju būtų galima aprūpinti kariuomenę ir gyventojus, neardant socialinių santykių, kurie sudaro valstybès pagrindą. Tam reikejjo turèti: maisto

95 Ten pat, 1. 99.

96 Ten pat, 1. 99-100. 
produktų ir pramonės gaminių išteklių, pramonės įmonių, žaliavų ir darbininkų, prekybos tinklą, susisiekimo priemonių ir lèšų.

Maisto produktų Lietuvoje taikos metu buvo gaminama daugiau negu suvartojama. Šis perteklius sudarè valstybès ekonominio gyvenimo pagrindą. Žemès ūkio veikla vertèsi apie 85 proc. visų šalies gyventojų. Vykdant mobilizaciją pirmiausia reikèjo žiūrèti, kad ši pamatinė Lietuvos ùkio šaka kuo mažiau nukentėtų dèl darbininkų skaičiaus sumažejjimo, taip pat atkreipti dèmesị $\mathfrak{i}$ tai, kad javų derlius kiekvienais metais būna skirtingas. Todèl, rengiantis karui, reikejjo pasiruošti iš užsienio net ir žemès ūkio produktus įsivežti.

Visos priemonès, kurių reikejo imtis šioje srityje, turejjo būti numatytos tam tikro valdžios organo. Tačiau apie tokio organo egzistavimą nieko nebuvo žinoma.

Bendram pramonès gaminių šalies apyvartoje ir sandèliuose kiekiui nustatyti duomenų neturèta. Didesnių atsargų sudaryti nesugebėta. Lietuvos primityvios struktūros prekyba su užsieniu vyko kol kas neturint didesnių sandèlių, išskyrus du javų elevatorius Šiauliuose ir Kaune. Turètų šiuo laikotarpiu ratinių transporto priemonių skaičius nežinomas, mobilizacijai šioje srityje nepasiruošta.

Šalies pramonė taip pat rèmèsi žemès ūkiu. Maisto produktų ịmonès galejo visiškai patenkinti krašto poreikius, tik cukraus gamyba nevyko.

Kitos didžiosios įmonès, pavyzdžiui, metalo ir odos apdirbimo, sukurtos dar carinès Rusijos valdymo laikotarpiu, sąlygoms pakitus, sumenko, prisitaike prie krašto išteklių ir poreikių. Vien odos apdirbimo pramonė pagal gaminių rūšių ịvairovę ir kiekị atitiko visus šios srities reikalavimus. Metalo apdirbimo immonès specializavosi gamindamos produkciją tam tikroms ūkio šakoms, tačiau tik iš dalies patenkino krašto reikmes. Be to, beveik visas žaliavas joms teko įsivežti iš užsienio. Medžio apdirbimo fabrikai apsiribojo pusfabrikačių gamyba. Audimo pramonės buvo tik daigai. Tą pati galima pasakyti apie stiklo gamybą. Kitos pramonès šakos dèl savo masto arba kokybès buvo ne tokios svarbios aprūpinant šalį ir kariuomenę reikalingais gaminiais.

Apskritai Lietuvos pramonė buvo sutelkta trijuose centruose: Kaune - metalo (ten buvo ir centrinès kariuomenès dirbtuvès), Šiauliuose odos, Klaipėdoje - medžio apdirbimo. Be to, Panevėžio rajonas garsejjo malūnais (grūdų malimo pramone) ir alkoholio gamybos įmonèmis. 
Tenka konstatuoti, kad Lietuvos pramonè galëjo patenkinti labai mažai kariuomenès reikmių. Todèl, kilus karui, tiekimas iš užsienio būtų buvęs itin svarbus. Taigi ir šalies susisiekimo su užsieniu linijų apsauga turèjo būti rūpinamasi pirmiausia. Didesnis pavojus Lenkijos puolimo atveju grèsè Lietuvos metalo pramonei, kuri buvo sutelkta Kaune. Tuo labiau kad tai buvo sritis, tiesiogiai susijusi su karo reikalais. Plètoti metalo apdirbimo pramonę Žemaitijoje, nors ir nedideliu mastu, turèjo būti laikoma svarbiu valstybiniu uždaviniu.

Rūpestị kèle ir kvalifikuotų darbininkų trūkumas. Taikos metu to nebuvo juntama, tačiau pareikalavus daug žmonių ịtraukti ị kariuomenès eiles, padètis galejjo gerokai pasikeisti. Norint, kad jų pakaktų ir mobilizuotai kariuomenei, ir šalies pramonei, reikejo susirūpinti - parengti šios srities veiklos planą, kurio iki tol nebuvo ${ }^{97}$.

Pastaraisiais metais šalies prekybininkai jau buvo susibūrę ì keletą didesnių organizacijų (Ūkininkų sąjungą, Lietuvos kooperacijos bendrovių sąjungą ir kt.). Šie organai bendros Finansų ministerijos Prekybos departamento vadovybės turejjo būti kuo daugiau remiami, pritaikymo karo reikmėms klausimas turèjo būti jų pačių ir tam tikrų valdžios organų (Vyriausiosios krašto apsaugos tarybos - V. L.) svarstomas ir sprendžiamas.

Dèl užsienio prekybos svarbos šalies vadovybė buvo priversta atkreipti ypatingą dėmesị ị prekybos kelių už Lietuvos ribų saugumą. Pagrindiniai tokie keliai buvo trys: Klaipèda, Virbalis ir Mažeikiai. Klaipėdos apyvarta buvo didžiausia, Virbalio - kiek mažesnè, bet tai buvo svarbiausia šalies importo kryptis. Mažeikių kryptis - ne tokia svarbi, nes ja keliavo eksportuojamos prekès ir ištekliai. Išvada - pagrindinès Lietuvos prekybos arterijos ejjo per Klaipėdą-Pagègius ir Virbalị.

Apibūdinant šalies kelių tinklą labai svarbūs buvo šie faktai:

1. Nedidelis geležinkelių infrastruktūros pajègumas. Priežastys daugumą jų buvo vienavèžiai, dideli atstumai tarp stočių, mažai įrengta vandentraukių, kokybiškų signalizacijos priemonių, riedmenų, rampų ir kt. trūkumas.

Didesnès geležinkelio krovimo rampos (20 vagonų ir daugiau) buvo Alytuje, Dabikineje, Kaišiadoryse, Kaune, Kèdainiuose, Radviliškyje, Šiauliuose ir Virbalyje. Kai kurios jų buvo labai blogos būklès. Kiekvienam

97 Ten pat, 1. 101-102. 
plačiụjų geležinkelių $100 \mathrm{~km}$ teko 16 garvežių, 15 keleivinių vagonų, 225 prekiniai vagonai. Tai buvo labai mažai.

Esant tokiai padéčiai, vienam karo meto sudeties pulkui pervežti iš Panevėžio ị Kèdainius reikèjo mažiausiai apie 20 valandų (įskaitant ịlaipinimą, išlaipinimą, turto pakrovimą ir iškrovimą).

2. Iš viso buvo nutiesta $1125 \mathrm{~km}$ geležinkelio. Tai reiškè, kad kiekvienam $100 \mathrm{~km}$ teritorijos teko apie $2 \mathrm{~km}$ geležinkelio. Šis skaičius buvo itin mažas, palyginti su Vakarų Europos normomis (10-12 km). Žemaitijos centre ir Aukštaitijoje buvo vietų, nutolusių nuo plačiụjų geležinkelių daugiau kaip $60 \mathrm{~km} .563 \mathrm{~km}$ siaurųjų geležinkelių beveik neturèjo ịtakos bendrai padéčiai. Bendras geležinkelių tinklo išdèstymas šalies ekonominių ir karinių interesų požiūriu nebuvo tobulas. Jonavos rajone nuo geležinkelio iki Lenkijos sienos buvo $32 \mathrm{~km}$, Virbalio rajone - tik $27 \mathrm{~km}$, o pačios linijos nedengè jokia gamtinè kliūtis.

3. Geležinkelių naudojimo, kilus karui, sistema nebuvo organizuota. Ryši tarp Krašto apsaugos ir Susisiekimo ministerijų palaikè vien Kauno stoties komendantas, kurio pareigos buvo kaip policininko arba reprezentacinès. Todèl faktiškai ryšio tarp minètų žinybų nebuvo - neruošta nei dirva, nei personalas, kad karo metu geležinkelius būtų galima tinkamai eksploatuoti. Krašto apsaugos ministerija įtakos sprendžiant klausimus dèl geležinkeliụ tiesimo ir aprūpinimo ịranga iki tol neturèjo.

4. Daugiau plentų buvo nutiesta tik pietinejje Suvalkijos dalyje. Kitoje Nemuno pusèje, jų, be Tauragès-Joniškio ir Kauno-Zarasų plentų, nebuvo. Abu minèti plentai buvo nutiesti pagrindine operatyvine kryptimi, numatyta karo su lenkais atveju, todèl galejo būti naudojami vien kaip rokados, tačiau Kauno-Zarasų plentas galejjo greitai netekti strateginès reikšmès dèl to, kad buvo arti sienos.

Iš Suvalkijos plentų svarbesni buvo Kauno-Suvalkų, Kauno-AlytausSeinų ir Gardino plentai, galintys lokalizuoti Lenkijos pajègų smūgius iš pietų. Čia teko atkreipti dèmesị ir ị Nemuno nuo lenkų dengiamą plentą Kaunas-Alytus (per Balbieriškị).

5. Grunto keliai buvo blogi, ypač molètose vietose.

6. Vandens kelių buvo keletas (iš viso $471 \mathrm{~km}$ ) - vien Nemunu iki Alytaus, Nerimi iki Jonavos ir Nevèžiu iki Babtų plaukiojo 23 garlaiviai (iš viso $800 \mathrm{t}$, greitis $10-16 \mathrm{~km} / \mathrm{val}$.) ir 93 nemotorinès baržos. Šių plaukiamujų priemonių naudoti karo tikslams nebuvo rengiamasi. 
7. Didesnių kelių tiltai, nuolat taisomi, buvo geros būklès, mažesnių kelių - prastos. Pažymètina, kad trūko tiltų per Nemuną Kauno-Pagėgių ruože, net keltai padèties nepagerino.

Apskritai tenka konstatuoti, kad tuo metu kelių tinklas buvo labai retas ir svarbiais atvejais negalejjo patenkinti šalies gynybinių poreikių ${ }^{98}$.

Kaip jau minèta, Lietuvos visuomeninio ir valstybinio turto pagrindas aptariamuoju laikotarpiu buvo žemès ūkis. Jis ir iki Pirmojo pasaulinio karo dèl ịvairių priežasčių nebuvo labai našus. Šis karas, Nepriklausomybès kovos ir ịvykdytos reformos sunaikino pirmykštị aparatą, todèl svarbiausias šalies turto prieaugis vis dar buvo palyginti mažas. Ir vèlesniais metais jis didejo labai lètai. Pradejus savarankiškai gyventi, iš praejjusių laikų daug turto: pinigų, lengvai realizuojamų gèrybių ir t. t., išskyrus mišką, nepaveldèta. Todèl ir aptariamuoju laikotarpiu turèta labai mažai tobuliausio apyvartos kapitalo - pinigų. Jų vos pakako kasdienio gyvenimo reikalams ir greit igyvendinamoms operacijoms finansuoti, todèl valstybe kariniam pasirengimui galëjo skirti tik mažas sumas. Vis dèlto tam tikrų rūšių karinèms pajègoms išlaikyti ir jų būtiniausioms išlaidoms padengti reikejo rasti lèšų. Kadangi karo pajėgoms didinti pinigų neturèta, prie finansinių galimybių teko derinti pačią kariuomenès organizaciją. Vadinasi, kilus karo pavojui, valstybei būtų tekę griebtis vidaus ir užsienio paskolų. Visoms šioms operacijoms atlikti reikèjo turèti finansinès mobilizacijos planą, tačiau jo rengimu tuo metu dar niekas nesirūpino. Tai reikejo padaryti labai greitai, nes jau po pirmų žygių, neplaningai išnaudojus savo šalies lěšas, kiltų grèsmè likti be finansavimo šaltinių. Kiek to meto šalies finansai būtų leidę padidinti Lietuvos karines pajègas, nebuvo apskaičiuota99.

Dar nevisiškai buvo sutvarkytas ir valstybès administracinis aparatas, nes neatsižvelgta ị šalies pasiruošimą karui. Šie trūkumai atsirado dèl to, kad neturèta tarpžinybinio organo šalies gynybos reikalams tvarkyti. Teoriniai samprotavimai ir praktika parode், kad ministrų kabinetas šio organo neatstoja, nes reikejjo turèti nuolatinę specializuotą techninę dalị. $\mathrm{O}$ šiuo laikotarpiu tarpžinybinis bendradarbiavimas daugiausia vyko asmenine žinybų vadovų nuožiūra, todèl, jiems keičiantis, neretai nutrūkdavo, keitè savo kryptị ir apskritai buvo apleistas.

98 Ten pat, 1. 103-105.

99 Ten pat, 1. 106. 
Šalies ịstatymų leidimo organų kompetencija ir kontrolès reikšmė karo atveju nebuvo įvertinta, administracinio aparato funkcionavimas, savivaldybių ir teritorinių valdymo organų veikla nesureguliuota. Remtasi vien rusų „Položenije o polevom upravleniji voisk“, kuris netiko šiems reikalams tvarkyti dèl kitokios valstybès santvarkos.

Kilus konfliktui su lenkais, Lietuvos demokratinès tendencijos turèjo būti laikomos teigiamu veiksniu, nes iki tol lenkai mūsų visuomenès akyse atstovavo priešiškai socialinei pakraipai. Kaip neigiamą socialini reiškinį aptariamuoju laikotarpiu galima paminèti žemą pilietinį sąmoningumą, kas leido valstybès priešams pamėginti išprovokuoti dali Lietuvos visuomenès, nors ir šioje srityje lenkai turejjo mažai galimybių ${ }^{100}$.

Kaip matyti, šiame Vyr. štabo Operacijų skyriaus parengtame didelès apimties koncentracijos plane buvo išsamiai išanalizuota ir ịvertinta tuometè reali padètis, susidariusi Lietuvos ginkluotosiose pajegose ir su jomis gyvybiškai susijusiose valstybės institucijose, kartu nurodyta jų veiklos kryptis, atskleista jų reikšmė didinant krašto gynybinị pajègumą galimo karinio konflikto su lenkais atveju.

Taigi 1926-ieji liko įsimintini kaip aršios priešpriešos ir konflikto su lenkais metai. To meto Lenkijos visuomenès požiūriu, „lenkų-lietuvių santykiai per visus metus taip ir neišèjo iš užkeikto rato "101.

Tų metų pabaigoje padètis tapo dar sudètingesné, gruodžio $17 \mathrm{~d}$. ịvykus valstybès perversmui ir ị valdžią atejus tautininkų vadams A. Smetonai ir A. Voldemarui, kurių antilenkiškas nusistatymas niekam nebuvo paslaptis. Gruodžio 20 d., kalbėdamas spaudos atstovams apie vyriausybès užsienio politiką, A. Voldemaras pažymejo, jog grąžinti Vilnių - pats mažiausias lietuvių reikalavimas, kadangi „Vilniaus atsisakymas Lietuvoje būtu ịvertintas kaip valstybės išdavimas" ${ }^{\text {"102 }}$. O J. Pilsudskis tvirtino, kad jo kantrybė baigiasi, ir leido suprasti, jog yra svarstęs drastiškos akcijos prieš Lietuvą galimybę, turẻdamas tikslą jèga užmegzti normalius santykius tarp šių dviejų valstybių ${ }^{103}$.

Ivykdę perversmą $\mathfrak{i}$ valdžią atėję tautininkai èmèsi esminių kariuomenès vadovybės pertvarkymų. Jau gruodžio $18 \mathrm{~d}$. plk. ltn. J. Papečkys

\footnotetext{
100 Ten pat, 1. 107.

${ }^{101}$ G. Vilkelis, Lietuvos ir Lenkijos santykiai Tauty Sajungoje, p. 145.

102 R. Žepkaitè, Diplomatija imperializmo tarnyboje, p. 191.

${ }^{103}$ V. Žalys, Lietuvos diplomatijos istorija (1925-1940), t. 1, p. 237.
} 
buvo atleistas iš krašto apsaugos ministro pareigų, o jo vieton paskirtas plk. ltn. A. Merkys ${ }^{104}$. Gruodžio 29 d. buvo atleistas ir Vyr. štabo viršininkas plk. ltn. K. Škirpa, jo pareigas peremė plk. T. Daukantas ${ }^{105}$. Ankstesnès kariuomenès vadovybės pradèti esminiai pertvarkymai toliau nebevyko. Taip baigèsi 1921-1926 m. laikotarpis.

\section{LIETUVOS KARIUOMENĖS VADOVYBĖS GYNYBOS PLANAI IR VEIKSMAI 1927-1937 M.}

\section{Naujos karinès vadovybès veiklos pradžia}

Kariuomenès įvykdytas M. Sleževičiaus vyriausybès nušalinimas buvo plačiai komentuojamas tiek Lietuvoje, tiek užsienio spaudoje. Kaimyninė Lenkija naujają Lietuvos valdžią sutiko labai nepasitikėdama. J. Pilsudskis dèl ịvykių Kaune dvi naktis tarèsi su ministrų kabinetu, kad galètų imtis visu priemoniu bet kokiais nenumatytais atvejais ${ }^{106}$. Lenkijos vadovybei ypač nerimą kèle $1927 \mathrm{~m}$. vasario $25 \mathrm{~d}$. Lietuvos vyriausybès deklaracijoje pabrèžtas teiginys, jog „Lietuva turi būti nepriklausoma ir su sostine Vilniuje "107. Kovą dèl Vilniaus A. Voldemaras laikè kova dèl visos Lietuvos ateities. „Neatgavę Vilniaus, negalèsime turèti Nepriklausomos Lietuvos“, teigé jis ${ }^{108}$. Lenkiją A. Voldemaras laike pikčiausiu priešu. „Su lenkais reikia kovoti be perstojo, be poilsio iki tol, kol Vilnius griš Lietuvon", - rašè jis ${ }^{109}$.

Atejusi ị valdžią naujoji kariuomenès vadovybe i aukštas pareigas skyrè karininkus, aktyviai dalyvavusius gruodžio $17 \mathrm{~d}$. perversme. Vienas iš pagrindinių perversmo organizatorių mjr. P. Plechavičius buvo paskirtas Gen. štabo viršininku, plk. V. Skorupskis - Vyr. štabo Administracijos valdybos viršininku ${ }^{110}$, plk. V. Grigaliūnas-Glovackis - Ypatingụjų

\footnotetext{
${ }^{104}$ Krašto apsaugos ministro 19261218 iqsakymai kariuomenei Nr. 106 ir Nr. 107, LCVA, f. 384, ap. 1, b. 73, 1. 143-144.

${ }^{105}$ Krašto apsaugos ministro 19261229 įsakymas kariuomenei Nr. $109 \$ 2$, ten pat, 1. 146 . ${ }^{106} L C V A$, f. 383 , ap. 7, b. $625,1.4$.

${ }^{107}$ Ministerių kabineto deklaracija, Lietuva, 19270226.

${ }^{108}$ Prof. A. Voldemaras, Raštai, 1973, Nr. 5, p. 558-561.

109 Ten pat.

${ }^{110}$ Krašto apsaugos ministro 19270104 iqsakymas kariuomenei Nr. $3 \$ 1, L C V A$, f. 384, ap. 1, b. $79,1.10$.
} 
reikalų karininku prie Krašto apsaugos ministro brigados vado teisèmis $^{111}$, gen. ltn. K. Ladyga - II karo apygardos viršininku ${ }^{112}$, kpt. S. Raštikis - Vyr. štabo Informacijų skyriaus viršininku ${ }^{113}$ ir t. t.

Buvo stiprinama ir vietine karinè valdžia. Nuo $1927 \mathrm{~m}$. vasario $1 \mathrm{~d}$. buvo įsteigtos Ukmergès, Kèdainių, Rokiškio, Mažeikių, Kretingos, Trakų, Tauragès, Vilkaviškio ir Klaipèdos karo sritys ${ }^{114}$.

Pradèjęs vadovauti Vyr. štabui ir susipažinęs su padètimi ginkluotosiose pajegose, plk. T. Daukantas $1927 \mathrm{~m}$. vasario $5 \mathrm{~d}$. raporte krašto apsaugos ministrui plk. ltn. A. Merkiui konstatavo, kad kariuomené visiškai nepasiruošusi atremti eventualių priešo puolimų. Jo teigimu, ypač bloga padètis aviacijoje, kur neturima nei parengto personalo, nei šiam tikslui pritaikytų pabūklų. Atkreipęs ministro dèmesị $\mathfrak{i}$ kaimyninių valstybių oro laivynų aukštą išsivystymo lygi, plk. T. Daukantas pareiške tokiomis sąlygomis negalįs prisiimti asmeninės atsakomybės už šalies gynybą karo atveju ir oro erdvės apsaugą taikos metu. Dèl visų šių priežasčiu buvo siūloma neatidèliojant ịsigyti reikiamų priešlèktuvinių pabūklų ${ }^{115}$.

Atsižvelgdamas ị minetas aplinkybes plk. T. Daukantas teigè, jog reikia būti nuolat pasirengusiems atremti kaimynų, pirmiausia lenkų, galimus puolimus, nes jie turi palyginti galingą oro laivyną ir ji be paliovos toliau stiprina. Jis atkreipe krašto apsaugos ministro démesį $\mathfrak{i}$ tai, kad sprendimas ịsigyti priešlèktuvinių pabūklų tik galimo karo išvakarèse nebepadètų, nes:

- gana sunku iš anksto tiksliai numatyti tokio karo pradžią;

- paskutinę minutę šių ginklų ỉsigyti būtų sunkiau ar net visai neįmanoma dèl sparčiai kintančiu politinių, prekybos ir transportavimo sąlygų;

- jei paskutinę minutę ir pavyktų jų ịsigyti, trūktų specialaus personalo, kuris galètų juos tinkamai naudoti, o specialistams parengti reikia laiko (apie 4 mèn.);

- norint, kad oro erdvės suverenumas būtų užtikrintas, priešlèktuvinių

${ }^{111}$ Krašto apsaugos ministro 19270126 ìsakymas kariuomenei Nr. $14 \$ 2$, ten pat, 1. 23. ${ }^{112}$ Krašto apsaugos ministro 19270211 įsakymas kariuomenei Nr. $23 \S 1$, ten pat, 1. 32. ${ }^{113}$ Krašto apsaugos ministro 19270302 issakymas kariuomenei Nr. 34 \$ 6, ten pat, 1. 46. ${ }^{114}$ Krašto apsaugos ministro 19270209 issakymas kariuomenei Nr. $21 \S 3$, ten pat, 1. 30. 115 Vyr. štabo viršininko plk. T. Daukanto 19270205 raportas Nr. 20223 krašto apsaugos ministrui, $L C V A$, f. 929 , ap. 3, b. 578, 1. 6. 
pabūklų būtina įsigyti dar taikos metu.

Vyr. štabe iki tol laikytasi nuomonès, kad kiekvienoje divizijoje reikètų turèti mažiausiai vieną priešlèktuvinę bateriją (iš viso keturias) ir vieną artilerijos grupę (iš viso 3-4 baterijas).

Visiems šiems pabūklams ịsigyti reikalingos lèšos turèjo būti numatytos ilgesniam laikotarpiui, todèl jų ịsigijimo klausimas, kaip ir visas ginklavimo planas, būtų sprendžiamas vadovaujantis ịstatymais, tam reikalingos lèšos skiriamos kitaip, negu sudarant paprastą metinį biudžetą ${ }^{116}$.

Spręsdama krašto apsaugos klausimus naujoji kariuomenès vadovybė ypatingą dèmesị skyrè Kauno, kaip Lietuvos laikinosios sotinès, gynybai. Jau tą pačią vasario 5 d. Gen. štabo valdybos viršininkas mjr. P. Plechavičius Vyr. štabo viršininko igaliojimu įsake II karo apygardos viršininkui kartu su artilerijos inspektoriumi parengti pabūklų ir kulkosvaidžiu pozicijas Kauno priešlèktuvinei apsaugai užtikrinti ${ }^{117}$. Be to, jam buvo issakyta imtis priemonių, kad laiku būtų sutaisyti 10 remontuotinų krovininių automobilių, kurie prireikus būtų naudojami kariuomenei vežti ${ }^{118}$. Tiekimų viršininkas turejjo pranešti Vyr. štabo viršininkui, kokių turịs sumanymų dèl artilerijos sandèlių užtikrinant priešlèktuvinę apsaugą, kas šiuo klausimu jau padaryta ${ }^{119}$.

Savo poziciją ir konkrečius pasiūlymus dèl pasirengimo galimai lenkų agresijai prieš Lietuvą atremti $1927 \mathrm{~m}$. kovo $11 \mathrm{~d}$. raporte krašto apsaugos ministrui aiškiai išdèstė kariuomenès vadas gen. S. Žukauskas ir Vyr. štabo viršininkas plk. T. Daukantas. Jų teigimu, „šiuo atveju, sudarant mobilizacijos planą, reikejjo turèti omenyje galimos kampanijos projektą ir galimų karo veiksmų planą (sustatyti mobilizacijos planą visiems galimiems nuotykiams, vis viena ką neturèti jokio plano)“120.

Tokiomis politinėmis aplinkybėmis visas dėmesys turëjo būti skirtas sienai su Lenkija okupuotoje Lietuvos dalyje, o kartu ir parengtas

116 Ten pat.

${ }^{117}$ Gen. štabo valdybos viršininko mjr. P. Plechavičiaus 19270205 raštas Nr. 20225 II karo apygardos viršininkui, ten pat, 1.7.

${ }^{118}$ Gen. štabo valdybos viršininko mjr. P. Plechavičiaus 19270205 raštas Nr. 20226 II karo apygardos viršininkui, ten pat, 1.8 .

${ }^{119}$ Gen. štabo valdybos viršininko mjr. P. Plechavičiaus 19270205 raštas Nr. 20227 tiekimų viršininkui, ten pat, 1. 9 .

${ }^{120}$ Kariuomenès vado gen. S. Žukausko ir Vyr. štabo viršininko plk. T. Daukanto 19270311 visiškai slaptas raportas Nr. 1 krašto apsaugos ministrui, ten pat, 1. 10 . 
atitinkamas tiek puolamųjų, tiek gynybinių veiksmų planas ir jam pritaikytas mobilizacijos planas.

Abiejų raporto autorių nuomone, galimais karo veiksmų pradžios rajonais laikytini:

1. centrinis rajonas: Kauno-Vilniaus geležinkelio linija ir teritorija abipus jos;

2. kairysis sparnas: Ukmergè-Jonava-Širvintos;

3. dešinysis sparnas: Varèna-Alytus-Marijampolè.

Turint omenyje, kad lietuvių ir lenkų konfliktas nebuvo išspręstas, Lenkija, susidūrusi su kuria nors valstybe, galèjo pastūmèti ir lietuvius su ginklu rankose stoti savo teisès į Vilnių ir Vilniaus kraštą ginti. Atsižvelgdama ị toki galimą pavojų, Lenkija lemiamu smūgiu galejo baigti užsitęsusi ginčą su Lietuva, ją nuginkluoti ir kartu apsaugoti savo pajègų kairijj sparną.

Šios aplinkybès vertẻ lietuvius susirūpinti: per kuo trumpiausią laiką pasiruošti apsaugoti savo kariuomenę, nes Kaunas - centrinè sandèlių ir visų administracinių ịstaigų vieta - buvo taip arti priešo, kad negalejo likti be apsaugos nè 24 val. Vienintelis geležinkelio tiltas per Nerị Jonavoje labai lengvai galèjo būti priešo sunaikintas. Tik juo buvo palaikomas ryšys su užnugariu, todèl jị sugadinus būtų paralyžiuota ir Kauno evakuacija, ir apskritai tiekimas.

Kariuomenès vadas, susipažinęs su Vyr. štabo parengtu detaliu mobilizacijos planu, pažymejjo, kad vis dèlto jame neatkreiptas dėmesys $\mathfrak{i}$ anksčiau išdėstytus argumentus, nes Kaunas iki trijų dienų liktų be apsaugos. Plane nebuvo numatyta ir mobilizacijos priedangos operacija.

Pirmąją mobilizacijos dieną išsiuntus ị frontą ne mažiau kaip penkis batalionus, II pèstininkų divizijos pulkai turejjo būti tokios sudèties, kad dalị jų žmonių būtų galima komandiruoti naujų kariuomenės dalių organizuoti, nesusilpninant jau veikiančių. Daugelio atsargos karininkų, kurie jau buvo užėmę administracinius (pvz., apskričių viršininkų) postus, nebebuvo galima iš jų atšaukti. Kai kurie èjo tokias pareigas, kad šaukti jų $\mathfrak{i}$ kariuomenę niekas net negalvojo. Padidinus II pėstininkų divizijos sudètị 20-22 karininkų etatais, būtų sudaryta galimybè normaliai veikti tuo metu Kaune esantiems 2-ajam ir 5-ajam péstininkų pulkams ${ }^{121}$.

Pašaukti ị kariuomenę artileristus nebuvo sunku. Rūpestị kèlè arklių

121 Ten pat, 1. 10-11. 
stoka. Dèl šios priežasties mūsų artilerija, kuriai jau pirmąją mobilizacijos dieną būtų tekę vykti ị frontą, šį uždavinị būtų įstengusi ịvykdyti tik trečiąją dieną. Todèl jau taikos metu būtina turèti tiek arklių, kad, mobilizaciją paskelbus, šovinius ir patrankas būtų galima gabenti ten, kur reikia.

Mokomoji baterija turejo būti taip organizuota, kad gebètų greitai persiformuoti i keturių baterijų pulką. Vieno artilerijos pulko, turinčio mažai sviedinių, jokiu būdu nebūtų užtekę Kaunui apginti.

Kavalerija turejo veikti Jonavos rajone ir kartu su 1-uoju pėstininkų pulku pridengti mobilizaciją, išlaikyti tiek strategijos, tiek taktikos požiūriu svarbų punktą, tiltus per Nerị, vienintelę geležinkelio liniją i užnugarị.

Kavalerijos pasirengimas numatytą uždavinị ịvykdyti toli gražu nebuvo patenkinamas:

1. Eskadronai buvo vos pusès etatinės sudèties. Atsargos eskadronams papildyti būtų tekę skirti nemažai žmonių ir arklių. Nežinia, kas būtų perèmęs judamąji ir nejudamąjj turtą pulkui vykstant $\mathfrak{i}$ frontą. Neturèta raitosios baterijos. Tai buvo nedovanotina klaida. Tačiau šovinių tokiai baterijai buvo sukaupta. Reikejo tučtuojau organizuoti bent atsargos būrị ir pavadinti jị eskadronu. Papildytas (skyrus žmonių ir arklių iš atsargos) jis galejo atlikti savo vaidmenị. Paskelbus mobilizaciją, buvo numatyta vieną eskadroną išformuoti, o jo būrius priskirti kitiems eskadronams.

Kariuomenès vado nuomone, tai būtų buvę neracionalu, tiesiog kenksminga. Geriau jau veikti kartu dviem eskadronams, negu karo pradžioje, t. y. pavojingiausiu valstybei metu, mažinti jų skaičių. Per 3-4 dienas atsirastų ir žmonių, ir arklių. Atsargos eskadronas pulką jau fronte papildytų iki numatytos etatinès sudèties.

2. Tučtuojau reikèjo įsigyti patrankų, nes sviedinių turèta. Priešingu atveju eskadronai nebūtų pakankamai kovingi ${ }^{122}$.

Kulkosvaidžiai ir artilerijos sviediniai buvo vežami paprastais poriniais vežimais. Pasak gen. S. Žukausko, neįmanoma įsivaizduoti, kaip jie galètų būti gabenami blogais keliais, dažnai kalvotomis arba pelkètomis vietovėmis. Savaime suprantama, kad daugeli kilometrų teks žmonėms eiti, juos traukti ir tam eikvoti labai reikalingas žygiui jejgas. O tuo metu visos kariuomenès tam naudojo vieno arklio traukiamus dviračius vežimèlius, todèl panašiais vežimèliais kuo greičiau reikejjo aprūpinti ir

122 Ten pat, 1. 12 . 


\section{Lietuvos kariuomenę.}

Dviejų pėstininkų pulkų - 3-iojo ir 6-ojo* - išformavimas skaudžiai atsiliepe pasiruošimo karui eigai. Mobilizacija buvo sunki ir sudètinga operacija, o formuoti naujas kariuomenès dalis, neturint net minimalaus skaičiaus kadrų, buvo beveik neįmanoma, todèl būtinai reikèjo atkurti anksčiau išformuotus pèstininkų pulkus.

Kadangi Kaunas buvo geležinkelių mazgas, o silpniausias jų taškas Jonavos tiltas, svarbus vaidmuo numatytas šarvuotiesiems traukiniams. Iš jų vienas turẻjo būti Kauno rajone, o kitas - i šiaurę nuo Jonavos. Todèl reikejjo žmonių, nors ir nedaug, šiems traukiniams prižiūrèti, kad, paskelbus mobilizaciją, jie būtų tinkami numatytoms užduotims atlikti.

Kauno rajonas ir jo užnugaryje buvusios sandèlių vietos turèjo būti bent minimaliai saugomos iš oro. Tam reikejjo suformuoti bent dvi zenitines baterijas ${ }^{123}$.

Vadovaudamasis kariuomenès vadovybès nurodymu II karo apygardos štabas 1927 m. kovo $23 \mathrm{~d}$. parengè detalų Kauno gynimo nuo priešo oro eskadrilių planą. Svarbiausi Kauno gynybos punktai, kuriuos reikejo saugoti nuo priešo lèktuvų, buvo šie: artilerijos sandèliai A. Šančiuose, A. Fredoje ir A. Panemuneje; aviacijos parkas; geležinkelio stotis, geležinkelio tiltas; Aleksotas, Slabados ir A. Panemunès tiltai, Krašto apsaugos ministerijos ir Seimo rūmai.

Aktyviąją gynybą turèjo vykdyti Lietuvos aviacijos naikintuvai, kurie, gavę Vyr. štabo pranešimą apie priešo lèktuvų perskridimo per mūsų frontą laiką ir kryptị, turejjo pagal tai apskaičiuotu laiku ir kryptimi pakilti ir atakuoti priešą.

Pasyviai gintis nuo priešo lèktuvų reikètų zenitiniais pabūklais ir kulkosvaidžiais, iš kurių buvo šaudoma šarvamušèmis kulkomis.

Kaunui, jo tiltams, sandèliams ir t. t. nuo priešo lèktuvų apginti reikèjo išdèstyti tris baterijas: vieną - Žaliojo kalno rajone, antrą - A. Fredoje, trečią - A. Šančiuose. Be to, iš baterijos ant Žaliojo kalno buvo galima apšaudyti šiuos rajonus: a) Aleksoto tilto, b) aviacijos parko, c) geležinkelio tilto ir stoties, d) Krašto apsaugos ministerijos ir Seimo rūmų; iš baterijos A. Fredoje: a) aviacijos angaro, b) artilerijos sandèlių, c) geležinkelio

Minèti 3-iasis ir 6-asis pèstininkų pulkai taupant lèšas buvo išformuoti $1926 \mathrm{~m}$. vasarą krašto apsaugos ministro plk. ltn. J. Papečkio įsakymais - V. L.

${ }^{123}$ LCVA, f. 929, ap. 3, b. 578, 1. 13. 
stoties ir tilto, d) A. Panemunès tilto, e) Krašto apsaugos ministerijos ir Seimo rūmų, f) Šančių kareivinių; iš baterijos A. Šančiuose: a) artilerijos sandèlių, b) geležinkelio stoties ir tilto, c) Panemunès tilto, d) Krašto apsaugos rūmų, e) Šančių kareivinių (iš dalies).

Turint mažai pabūklų, reikejo pasitenkinti trimis baterijomis, turinčiomis po du pabūklus.

Priešo lèktuvams sekti kiekviena baterija privalèjo turèti 1-2 šoninius sekimo punktus: baterijai Žaliajame kalne buvo priskirtas VI fortas ir Rotušè, A. Fredoje - I fortas ir Napoleono kalnas, A. Šančiuose - IV fortas ir artilerijos sandèliai. Vienas priešlèktuvinès artilerijos sekimo ir kulkosvaidžių punktas turèjo būti arti Vyr. štabo Operacijų skyriaus viršininko, su kuriuo privalejjo palaikyti ryši telefonu, būstinès. Geriausia vieta šiam punktui įkurti buvo Igulos bažnyčios bokštas.

Kaunui nuo lèktuvų ginti buvo numatyta pastatyti kulkosvaidžius šiose vietose: artilerijos sandèliuose -4 , aviacijos parke -4 , geležinkelio stotyje ir prie tilto -2 , Krašto apsaugos ministerijoje -2 , prie medinių tiltų - po 2.

Kiekviena baterija privalèjo palaikyti ryši telefonu su priešlèktuvinès apsaugos viršininku, gretima baterija ir tiesiogiai su visais savo sekimo punktais. Kulkosvaidžių aikštelès turèjo būti sujungtos telefono ryšiu su priešlèktuvinès apsaugos viršininko centrine stotimi, o svarbesnès aikštelès - tiesiogiai su punktų, kuriuos turèjo ginti, viršininkais ${ }^{124}$.

Tą pačią dieną parengtas Kauno gynimo nuo priešo oro eskadrilių planas buvo pasiųstas Vyr. štabo artilerijos inspektoriui ir prašyta atlikti šias užduotis:

1. parengti stovo artilerijos pabūklams projektą;

2. sudaryti baterijų pozicijų planą, kokia tvarka ir kokio dydžio turi būti įrengti blindažai;

3. parengti specialaus stovo sunkiesiems kulkosvaidžiams projektą.

Gavus šiuos nurodymus, buvo galima atlikti likusius darbus: ịrengti pozicijas, sutvarkyti telefono tinklą, įrengti aikšteles sunkiesiems kulkosvaidžiams, numatyti pulkų užimtinas pozicijas ir kt. ${ }^{125}$

\footnotetext{
${ }^{124}$ E. II karo apygardos štabo viršininko p. plk. A. Šumskio 19270323 Kauno gynimo nuo priešo oro eskadrilių planas, ten pat, l. 72.

${ }^{125}$ E. II karo apygardos štabo viršininko 19270323 raštas Nr. 3033 artilerijos inspektoriui, $L C V A$, f. 510 , ap. 1, b. 143 , 1. 2.
} 
I toriaus plk. P. Uoginto atsakymas buvo gautas tik tų pačių metų rugsëjo 6 d. Iš jo turinio matyti, jog to meto Lietuvos kariuomené minètais klausimais dar neturèjo specialistų inžinierių - nei teoretikų, nei praktikų. Todèl II karo apygardos viršininkui buvo pasiūlyta vadovautis Rusijos arba Prancūzijos kariuomenèse naudotais lauko pabūklų ir sunkiesiems kulkosvaidžiams skirtų stovų brèžiniais ${ }^{126}$.

Tuo metu lenkai ir toliau nerimo. Lenkijos kariuomenès generalinio štabo II skyriaus Vilniaus punktas (Ekspozytura nr. 1 II odzialu sztabu generalnego w Wilnie) $1927 \mathrm{~m}$. pavasarị savo agentams Lietuvoje pavede atlikti keletą užduočių ir surinkti žinias dominančiais klausimais:

1. Lietuvos kariuomenès dislokacija, apginklavimas, ginklų rūšys, kalibrai, kokie pulkai kokios rūšies turi granatų;

2. ar prie pulkų ikurtos puskarininkių mokyklos (szkola podoficerska), kaip jos organizuotos ir kam tiesiogiai priklauso;

3. kareivių skaičius pulkuose, pulkų vadų vardai ir pavardès;

4. šaulių organizacija, apginklavimas, ginklų rūšys, skaičius ir kalibras;

5. šaulių organizacijos sutvarkymas Kaune ir provincijoje, kuriose apylinkèse jų yra daugiausiai, jų tiesioginè priklausomybé;

6. šaulių nuotaika;

7. užmegzti ryšius su karininkais, ypač artilerijos dalyse;

8. žǔtbūt gauti žinių apie Lietuvos aviacijos etatus.

Pažymètina, kad lenkams tuo metu ypač rūpèjo Lietuvos artilerijos ir aviacijos etatai. Noredami tai sužinoti, jie veikè ne tik Vilniuje, bet ir kitose vietovèse.

Krašto apsaugos ministras plk. ltn. A. Merkys ịsake ị tai atkreipti ypatingą dèmesi $i^{127}$.

Blogèjo ir vieši Lietuvos ir Lenkijos santykiai. Prasidèjo agitacija prieš Vilniaus lietuvių visuomenines organizacijas ir mokyklas. Stiprëjo reakcinių politinių grupuočių kurstomos antilietuviškos nuotaikos.

${ }^{126}$ Vyr. štabo artilerijos viršininko plk. Pr. Uoginto 19270906 slaptas raštas Nr. 1055 II karo apygardos viršininkui, LCVA, f. 929, ap. 3, b. 578, 1. 63-64.

${ }^{127}$ Vyr. štabo Operacijų skyriaus karo veiksmų 1924-1927 m. dienynas, LCVA, f. 929, ap. 3, b. 453, 1. 237-238; Vyr. štabo viršininko plk. T. Daukanto 19270516 visiškai slaptas aplinkraštis Nr. 14 , ten pat, b. $574,1.74$. 
Pasinaudodami sunkia Lietuvos vidaus padètimi po Tauragès pučo Lenkijos militaristai pradejjo rengtis karo veiksmams. Jau spalio pradžioje èmé aiškèti karinio užpuolimo panaudojant lietuvių politinius emigrantus - plečkaitininkus - pavojus ${ }^{128}$. R. Žepkaitès teigimu, Lenkijos militaristai buvo numatę žaibiškai užimti Kauną ir pasirašyti „taiką" su naujai sudaryta Lietuvos vyriausybe. Pasirašiusi tokią sutartị, Lietuva turètų užmegzti su Lenkija ryšius, artimus unijai. Po to pagrindinès Lenkijos karinès pajègos pasitrauktų iš Lietuvos, $\mathrm{o}$ „naujosios tvarkos apsauga būtų pavesta plečkaitininkų daliniams. Prireikus juos paremtų Lietuvoje paliktos nedidelès lenkų kariuomenès igulos. $1927 \mathrm{~m}$. rudeni Lietuvos pasienyje buvo dislokuoti Lenkijos kariniai daliniai “ ${ }^{\prime 29}$.

\section{Generalinio štabo Operacijų skyriaus}

\section{7 m. lapkričio 26 d. operatyvinis sumanymas Nr. 1}

Sparčiai blogèjant Lietuvos ir Lenkijos santykiams ir pastarajai pradejus rengtis karo veiksmams, Generalinio štabo Operacijų skyriaus viršininkas plk. B. Jakutis su to paties skyriaus karininku grupe parenge konkretu, paremtą to meto mobilizacijos duomenimis, operatyvini sumanymą-projektą. Šis dokumentas $1927 \mathrm{~m}$. lapkričio $26 \mathrm{~d}$. buvo ịteiktas naujajam Generalinio štabo valdybos viršininkui plk. P. Kubiliūnui.

Iš jo turinio matyti, jog Lenkijos karinè vadovybè tuo metu prieš Lietuvą buvo numačiusi panaudoti 3-5 pėstininkų divizijas (9-15 pèstininku pulkų), 36-54 artilerijos baterijas, 6-7 kavalerijos pulkus (24-28 eskadronus) ir jai tiesiogiai pavaldžias dar 2-4 artilerijos baterijas, slaptai ir viešai šias pajègas sutelkus numatytose bazèse, staiga pulti Lietuvą ir ją užgrobti. Ši sumanymą Lenkijos vadovybė grindè ne tiktai realia, deja, blogiausia Lietuvai, hipoteze, kadangi tuo metu:

a) Lietuva neturejjo karinių sajungininkių:Vokietija ir Latvija Lenkijai buvo lojalios, laikèsi neutraliteto, Sovietų Sajungos pozicija buvo neaiški.

b) Dèl politinès konjunktūros Lietuva buvo nusistačiusi visur rodyti savo taikingumą ir, vengdama viešai vykdyti mobilizaciją ir pajégų telkimą, užpuoliko apibūdinimą taike išimtinai lenkams.

Laikantis čia išdèstytos motyvacijos reikètų sutikti, jog lietuviu vieša

${ }^{128}$ R. Čepas, Plečkaitininkai, Vilnius, 2000.

${ }^{129}$ R. Žepkaitè, Diplomatija imperializmo tarnyboje..., p. 198. 
mobilizacija galèjo būti paskelbta tiktai lenkams neteisètai perejjus demarkacijos liniją.

c) Lietuvos karinis potencialas rèmėsi to meto materialinių išteklių galimybėmis arba, konkrečiai kalbant, mobilizacijos tvarkaraščiu Nr. 5, pagal kuri buvo numatyta turèti keturias pėstininkų divizijas, tačiau jos visais aspektais būtų buvusios silpnesnès už analogiškas Lenkijos karines dalis.

Tikètasi, kad ateinančios žiemos darbai bus skirti Lietuvos karinių pajègų koviniam potencialui kelti, pirmiausia rūpinantis kariuomenès materialine padètimi: didžiụjų vienetų bent minimaliu aprūpinimu artilerija, pestijos materialiniu ir organizaciniu stiprinimu, tarnybų ir struktūros organizavimu, galimybemis ịsteigti nors vieną artilerijos pulką ir t. t., nekalbant jau apie visų armijos rūšių aprūpinimą.

Taigi, pagal operatyvinị sumanymą Nr. 1 kariuomenè turèjo būti sudaryta iš keturių pèstininkų divizijų ${ }^{130}$.

Nustačius šio sumanymo pagrindinius elementus, toliau samprotaujant, antrajame skyriuje pereita prie strateginès geografinès Lietuvos apžvalgos. Vertinant to meto demarkacijos linijos konfigūraciją pažymèta, kad Kauno rajonas, kurio hidrografinis tinklas gana sudetingas, yra centrinis Lietuvos strateginis mazgas, $\mathfrak{i}$ kurị nukreiptos trys ar keturios svarbiausios Lenkijos pajègų puolimo kryptys (pagal jų dislokaciją):

a) artimiausia operatyviné lenkų kryptis - Vilnius-Kaunas $(60 \mathrm{~km}$ nuo demarkacijos linijos);

b) tarpas Vilnius-Ukmergè-Jonava;

c) išilgai Nemuno nuo Gardino;

d) išilgai plento Suvalkai-Marijampolè-Kaunas;

e) išilgai Vokietijos sienos nuo Suvalkų per Vilkaviškị link žemutinio Nemuno.

Trumpai išnagrinejjus kiekvieną iš šių operatyvinių krypčiu buvo konstatuota:

a) Vilniaus-Kauno kryptis visais aspektais patogi didesnėms Lenkijos kariuomenès dalims veikti (artilerijos glaudžiam ryšiui su pėstininkais užtikrinti). Šia kryptimi nuo demarkacijos linijos iki Kauno buvo tik du pestininkų etapai.

${ }^{130}$ LCVA, f. 929 , ap. 3 , b. $578,1.30-31$. 
Nagrinėjant šios krypties patogumus gynybos požiūriu buvo išskiriamas Pravieniškių miškų rajonas, kuris, nors ir pereinamas, vis dèlto artilerijos masiniams veiksmams kartu su pèstininkais netiko. Pažymètina, kad lietuvių 5-ojo péstininkų pulko numatyti manevrai ir buvo rengiami i tai atsižvelgiant.

b) Kryptis nuo Vilniaus link Ukmergès-Jonavos tarpo iki Neries dešiniojo kranto visais aspektais buvo patogi didesnèms kariuomenès dalims veikti.

Sumanyme pabrèžti du svarbūs punktai: patogus Bagaslaviškio-Gelvonų rajonas ir Šventosios upės riba. Buvo teigiama, kad jos dešinysis krantas dèl daugelio priežasčių (Veprių rajone) nèra jau toks patogus gintis, kaip gali atrodyti žemèlapyje. Priešingai, kairysis Šventosios krantas sudarè kur kas patogesnes sąlygas puolantiems nuo demarkacijos linijos pusès (šis teiginys buvo paremtas išvadomis po paskutinių lauko pratybų - V. L.).

Nuo vadinamojo Maišiagalos „snapo“ iki Jonavos iš viso buvo $40 \mathrm{~km}$ (vienas kavalerijos etapas), iki Ukmergès - 36 km, o iki Šventosios linijos tarp Ukmergès ir Jonavos - tik $30 \mathrm{~km}$. Nagrinejjant Jonavos-Kèdainių krypties priedangos klausimą, teko atkreipti dèmesị ir ị Lokès upelio ribą, kuri galejo būti patogi gynybai vykdyti. Galimo puolimo per Jonavos-Ukmergès tarpą Kèdainių link atveju, pasirodo, priešo pèstininkų dalys turètų îveikti mažiausiai tris etapus. Be to, reikejo atkreipti ypatingą dèmesị ị labai svarbų Jonavos rajoną.

Išvada - šios srities karinè rekognoskuote tuo metu toli gražu dar nebuvo baigta, todèl karininkų artimiausios užduotys turèjo būti skirtos kaip tik šiam rajonui išstudijuoti.

c) Kryptis nuo Gardino link Kauno išilgai Nemuno.

d) Kryptis nuo Suvalkų Kauno link išilgai plento Kalvarija-Marijampolè.

e) Kryptis nuo Suvalkų per Vilkaviškị link žemutinio Nemuno išilgai Vokietijos sienos.

Pastarosios trys kryptys tuometemis sąlygomis sudarè Suvalkijos strategini vienetą, todèl jis ir buvo nagrinèjamas. Svarbiausia Suvalkijos ypatybè - jos geografinè padetis. Suvalkiją kirto ir nuo likusios Lietuvos skyrè Nemunas - svarbiausias mūsų strateginių kombinacijų „veiksnys“. Kita šio krašto ypatybė - klampus dirvožemis, pelkès (lenk. Bagno Buchcianskie ir Bagno Amalwa), kurių natūrali tąsa buvo Kazlų Rūdos 
miškai iki pat Nemuno. Šios pelkès nebuvo strategiškai svarbios, tačiau Kazlų Rūdos miškai, pradedant nuo Pilviškių-Skriaudžių linijos, skyrè šiaurinę Suvalkijos dalị ị du aiškiai skirtingus plotus: Šakių rajoną ir Kauno plento ruožą. Todèl ir Lenkijos pajègų puolimas iš Suvalkijos Nemuno link neišvengiamai turejjo krypti arba Kauno, arba žemutinio Nemuno per Šakius link, arba abiem kryptimis. Be to, buvo pastebèta, kad neokupuotos Suvalkijos pietinė dalis gana raižyta, tankiai prisèta ledyninès kilmès ežerèlių, kurie, sumaniai pasinaudojus jų konfigūracija, galèjo turèti nemažą taktinę reikšmę priedangos dalių veiksmams.

Vertinant Vilkaviškio-Šakių kryptị reikèjo atkreipti dèmesị i gana patogią sekimo padètị, žemèlapyje pavaizduotą Šešupès, Novos upėmis ir t. t. Palyginti su kitais Lietuvos plotais, Suvalkijos plentų tinklas buvo gana tankus, kas, be abejo, labai didelis privalumas kovojant techniškai geriau aprūpintoms (artilerijos, šarvuotųjų automobilių) dalims. Tačiau šia aplinkybe tuo metu lietuviai dar negalejo pasinaudoti. Artimiausia demarkacijos linijai Nemuno kryptimi buvo laikoma Vilkaviškio-Šakių kryptis $(80 \mathrm{~km})$. Kitos dvi kryptys nuo Kauno iki demarkacijos linijos tęsėsi apie $100 \mathrm{~km}$. Taigi per rekognoskuotę reikèjo įvertinti tiek abu Nemuno krantus, tiek Šakių kryptị kavalerijos požiūriu.

Baigus aptarti Suvalkijos operacijos teatro ypatumus, reikejo atkreipti dèmesị $\mathfrak{i}$ tai, kad Vilniaus-Gardino geležinkelio linija, kaip svarbiausia išsklaidyto III K. O. P. dalių artimiausia vakarinè aprūpinimo arterija, buvo prie pat Lietuvos ir Lenkijos demarkacijos linijos, todèl susprogdinti numatytus tiltus (beje, sunkiai pataisomus) jau pirmosiomis konflikto valandomis labai lengvai galejo kavalerijos iš Alytaus dalys.

Zarasų-Molètų baras, ịvertinus lietuvių strategines galimybes, turejjo būti laikomas ne tokiu svarbiu, tad jame didesnių kariuomenès operacijų tuo metu nebuvo numatyta. Kavalerijos, smulkesnių kariuomenès ar nereguliariųjų dalių veiksmus vykdyti čia būtų buvę gerokai lengviau dèl daugybès nedidelių ežerų, tarp kurių esantiems tarpams stebėti ir ginti nereikèjo gausių pajègų.

Kauno rajonas dèl savo strateginès padèties galèjo būti vadinamas centriniu. Tai buvo vienintelè Lietuvos kariuomenès sutelkimo zona. Ivvertinęs Kauno rajono hidrografinę sistemą, Gen. štabo Operacijų skyrius konstatavo, kad ji yra gana patogi. Nemuno reikšmè buvo tokia didelè, kad jị forsuojančiuosius iš Suvalkijos pusès buvo galima lengvai 
sustabdyti turint net ir daug mažesnes pajègas. Tai buvo vienintelis lietuviu gynybos baras, kuriame galimas igyvendinti karo „ekonomijos“ principas - taupyti, racionaliai panaudoti savo pajègas. Laikydamiesi hipotezès dèl pagrindinio lenkų puolimo nuo Vilniaus dešiniuoju Nemuno ar Neries krantu Kauno link (apie 75 km), Operaciju skyriaus karininkai priejo prie nuomonès, kad Kauno rajone Lietuvos kariuomenè jo prieigoms ginti galètų pirmiausia panaudoti:

a) pelkètą Pravieniškių rajoną tarp Neries ir Nemuno;

b) žemiau Neries prie Jonavos pakrantes su dešiniajame krante plytinčiais Vandžiogalos miškais, kurie sudarytų labai palankias sąlygas Kaune sutelktai divizijai racionaliai veikti. Miškingas Neveězio upès slènis, Vandžiogalos miškai ir toliau i vakarus nusitęsę taip pat miškingi Dubysos krantai bei tarpiniai ruožai buvo labai patogūs lietuvių mažesnèms negu priešo pajègoms kovoti.

Lietuvos kariuomenei laiku nespëjus susitelkti, veikiančiosios dalys galèjo sèkmingai išnaudoti šios srities gynybai palankias ypatybes ir kartu laimèti laiko telkimuisi baigti.

Šalies artilerijos silpnumą turejo bent iš dalies kompensuoti galimybẻ pasinaudoti miškų dengiamomis vietomis, kur priešas būtų priverstas veikti plačiai išsklaidęs savo artileriją, taigi kartu ir netektų pranašumo, kuri suteikia masinis pirminis jos panaudojimas. Jei baigusi susitelkti Lietuvos kariuomenè dèl bendro nepalankaus jègų santykio ir būtų priversta laikytis gynybinès ar atsitraukimo taktikos, ji galètų pasinaudoti šio rajono geografine konfigūracija (padètimi pagal ginamas ribas), kuri buvo labai patogi atsitraukimo kautynèms.

Užèmusi ši rajoną, Lietuvos kariuomené galèjo atremti savo dešinijj sparną $\mathfrak{x}$ lengvai ginamas Nemuno pakrantes. Tada mūsų vadovybei jai patogiu momentu paprasčiau būtų buvę sutelkti reikalingas manevrines pajegas kitoje fronto vietoje.

Tuo vadovaudamasi Operacijų skyriaus vadovybė pabrèžè abiejų Nemuno krantų žemiau Kauno rekognoskuotės reikšmę. Akcentuota, jog šis darbas būtinai turi būti atliktas ${ }^{131}$.

Bendrais bruožais aptarus Lietuvos teritorijos strategiškai svarbią geografinę konfigūraciją, minètame dokumente daug vietos skiriama konkrečiam strateginiam sumanymui ir jo pritaikymui keturių diviziju

${ }^{131}$ Ten pat, $1.32-35$. 
kariuomenei.

Kaip jau buvo minèta, šio sumanymo pagrindu buvo pasirinkta visais požiūriais blogiausia hipotezè - staigus lenkų puolimas, kai lietuvių mobilizacija pradedama jų invazijos $\mathfrak{i}$ Lietuvos teritoriją dieną. Turint omenyje priimtą hipotezę dèl galimo lenkų puolimo šešiomis divizijomis, reikejo a priori nustatyti, kad vienintelis pradinis veikimo būdas bus judrios gynybinès kautynès, o galbūt, blogiausiu atveju, ir atsitraukimas. Viskas turèjo priklausyti nuo priešo pajègų dydžio ir paskirstymo operacinèmis kryptimis. Manyta, jog galutinis veikimo būdas (sukonkretintas operacijų planas) paaiškès tik lenkų puolimo metu. Visais galimais atvejais bene labiausiai reikejjo rūpintis Lietuvos karių išsaugojimu. Apibūdinus pagrindinius galimos operacijos elementus (pajègų santykį, laiką), buvo galima pradèti praktiškai vykdyti ši sumanymą ir pirmiausia spręsti, kur sutelkti savo negausias pajègas. Atsakymas galejjo būti vienas - ten, kur lietuvių pajègos galètų ramiai, priešo netrukdomos, prieš operaciją užimti savo zonas, t. y. susitelkti kuo arčiau Lietuvos ir Lenkijos demarkacijos linijos, nes tada būtų didesnè tikimybè laimèti bent 4-5 dienas, o atitraukiant susitelkimo zoną kuo toliau ị vakarus, padidinti susitelkimo apsaugos ruožą. Tačiau atsižvelgiant i tai, kad Lietuvos teritorija yra nedidelé, minètos sąlygos priverstų atsisakyti lenkų naudai apie pusės krašto ploto, taip pat ir labai svarbaus Kauno rajono, kuris, galima sakyti, yra vienintelis patogus galimiems veiksmams vykdyti. Todèl Lietuvos kariuomenès branduolio sutelkimas galèjo būti visais aspektais patogiai atliktas Kauno-Kèdainių-Jonavos trikampyje. Šio pasiūlymo šalininkai savo samprotavimus rèmè dviem motyvais: išlaikydami Jonavos punktą, išnaudotume patogias Neries upès pozicijas ir, be to, savo rankose turètume labai svarbią geležinkelio liniją.

Pažymėtina, jog Operacijų skyrius šiems dviem tokiems svarbiems motyvams iš principo neprieštaravo, nes jie buvo visiškai teisingi. Tačiau, Operacijų skyriaus nuomone, klausimas buvo visiškai kitas. Negalima pamiršti, kad Jonavos punktas buvo vos $40 \mathrm{~km}$ atstumu nuo demarkacijos linijos, t. y. per vieną lenkų kavalerijos etapą ir pusantro pėstijos etapo, taigi, lietuvių nuomone, lenkai būtų laimèję kelias dienas. Tad vienos divizijos telkimas Jonavos rajone reikštų, kad ji atsiduria pačioje lietuvių strateginès dispozicijos periferijoje, o tai neišvengiamai baigtųsi jos katastrofišku sunaikinimu dalimis. 
Spręsta dèl Kauno-Jonavos geležinkelio linijos išsaugojimo. Kaip jau buvo minèta, šio sumanymo tikslas buvo išnagrinèti mūsų konjunktūrą, jei lenkai iškart be jokio perspejimo ir lietuviams dar nepradejus mobilizacijos pultų 4-5 divizijomis. Kitomis aplinkybèmis užduotis išlaikyti Kauno-Jonavos geležinkeli būtų visiškai suprantama, tačiau šiuo atveju siekti geografini punktą išsaugoti Lietuvos kariams būtų buvę pražūtinga.

Operacijų skyriaus nuomone, Jonavos punktas net ir taikos metu turètų būti saugomas bent jau vieno bataliono, nes pagal tuometị bendrą pajègų paskirstymą, kilus konfliktui, jis būtų likęs visiškai be apsaugos. Tai leidžia daryti išvadą, kad ị Jonavos rajoną ir jam priklausančias Neries rajono gynybines pozicijas (aukščiau ir žemiau Jonavos) galima žiūrèti tik kaip ì priedangos dalių veikimo zoną.

Atsižvelgdamas ị Kauno rajono strateginę reikšmę, ị jo susisiekimo tinklo bei prieigų patogumą, galop i jų išlaikymo moralinę svarbą, Operacijų skyrius nusprendé, jog kraštinė (ị rytų pusę) riba, nuo kurios galima pradèti telkti pajègas, - ir tai tik geriausiomis mobilizacijos ir telkimo sąlygomis - negali būti arčiau nei Kèdainių-Vandžiogalos-Kauno linija.

Apžvelgęs šias susitelkimo zonos ribas, Operacijų skyrius prièjo prie šių išvadų:

1. trumpiausias atstumas nuo demarkacijos linijos iki susitelkimo zonos rytinès periferijos - $60 \mathrm{~km}$ (išilgai geležinkelio Kaunas-Vilnius) pèstijos gali būti ịveikiamas per du etapus;

2. susitelkimo zonos prieigos, Pravieniškių tarp Nemuno ir Neries miškai iš vienos pusès ir Neries aukščiau Kauno dešinysis krantas iš kitos, patogios gintis mažesnio atsparumo pajègoms, todèl gali būti labai naudingos mobilizacijos ir telkimo saugumui sustiprinti;

3. dešinysis susitelkimo zonos sparnas rèmèsi i Nemuną ir buvo jo dengiamas.

Šios zonos parinkimas Lietuvos pajègų tolesnèms operacijoms suteikè ganètinas komunikacijų linijų išlaikymo garantijas, nes, reikia pripažinti, vienintelė lietuvių visų galimų operacijų bazė, turinti priejjimą prie Baltijos jūros, buvo Žemaitija.

Operacijų skyriaus nuomone, galèjo būti sutelktos keturios mobilizuotos péstininkų divizijos: trys - rajone Kèdainiai-Labūnava-Kaunas-Ariogala, o IV pėstininkų divizija - Šiaulių-Kauno geležinkelio ruožo zonoje (Radviliškio rajone), numačius jos galimas transportavimo 
(atsižvelgus ị sumanytą kontrmanevro koncepciją) kryptis Kẻdainių, Raseinių ar pagaliau ir Panevėžio link. Buvo pabrèžiama, kad III pėstininkų divizija yra tokioje vietoje, jog, atsižvelgus ị aplinkybes, galètų būti vieno etapo laikotarpiu permesta ị Kẻdainių rajoną (i kairę nuo I divizijos) ar Kauno rajoną II pėstininkų divizijai sustiprinti, arba ịsiterpti tarp I ir II Kèdainiuose ir i pietus nuo Kèdainių. I pèstininkų divizija buvo sutelkta vieno etapo atstumu nuo II Kauno divizijos.

Šis sumanymas neperženge bendrosios koncepcijos ribų, tad buvo pasitenkinta bendromis operatyvinèmis idejomis. Tiekimo ir evakuacijos klausimai buvo palikti visiškai nuošaly.

Hipotezès priešo puolamiesiems manevrams atremti. Remiantis lenkų III korpuso apygardos dalių dislokacija, jų Lietuvos puolamoji operacija galejo būti vykdoma igyvendinant du sumanymus:

a) Lenkų III korpuso apygardos dalys puola iš tuo metu užimtų sutelkimo bazių, nukreipdamos pagrindinị puolamąji smūgi išilgai Vilniaus-Kauno geležinkelio linijos ir ị šiaurę nuo jos, pasitenkindamos demonstratyviaisiais savo pèstijos veiksmais Suvalkijoje. Nors buvo galima tikètis, kad jų I korpuso dalys (pvz., viena kavalerijos brigada) pabandys staigiu puolimu pasiekti žemutinị Nemuną (pvz., Jurbarko rajone) ir, persikèlusi per jị, užplūs Žemaitiją, siekdama dezorganizuoti Lietuvos pajėgų mobilizaciją. Reikètų pabrèžti, kad šis variantas atrodè galimas, nes nuo demarkacijos linijos iki Nemuno iš viso buvo tik $80 \mathrm{~km}(1,5 \mathrm{ka}-$ valerijos etapo).

Pagal šią hipotezę buvo galima tikètis, kad lenkai permes iš Vilniaus Kauno link 3-4 pèstininkų divizijas su 3-4 kavalerijos pulkais.

b) Antruoju atveju lenkai pasitenkina demonstratyviaisiais veiksmais judèdami iš Vilnijos Kauno link (pvz., viena pėstininkų divizija su kavalerijos brigada) ir vykdo pagrindinị puolimą Suvalkijoje išilgai Nemuno arba Marijampolès-Kauno plento ruože (3-4 pėstininkų divizijos su 2-3 kavalerijos pulkais). Tiketina, kad ir pirmuoju atveju lenkų kavalerija galètų mėginti forsuoti žemutinị Nemuną.

Ar lenkai lietuvius savo pagrindinèmis pajègomis būtų puolę iš Vilnijos, ar svarbiausiąa operacine kryptimi pasirinkę Suvalkiją, Lietuvos kariuomenė galejjo taikyti tik vieną operatyvinę koncepciją: pasinaudoti Nemunu ir savo pagrindines pajègas laikyti ị šiaurę nuo jo. Priešingu atveju, norèdami apginti visą šalies teritoriją, lietuviai nieko nebūtų 
išsaugoję, tik kordoniniame kare pražudę visą savo gyvąją jègą.

Kuris iš šių dviejų atvejų buvo tikètinas lenkų puolimo variantas ir kiek lietuvių pajėgų sutelkimo sumanymas galejo atitikti kontrmanevro galimybes?

I atvejis: a) lenkai nukreipia savo priešakinio baro pagrindinị smūgị (2-3 divizijas) Vilniaus-Kauno geležinkelio linija, visiškai teisingai manydami, jog tai trumpiausia operacinė kryptis Kauno link. Likusios pajègos (viena divizija su kavalerijos branduoliu) veiktų taip: pėstija pultu Kèdainių kryptimi (Ukmergès-Jonavos tarpe), siekdama apeiti lietuvių pajègų kairijj sparną ir kartu neutralizuoti jų atsparumą Kauno rajone. Pagrindinès kavalerijos pajègos tada permetamos dar toliau ị šiaurę, siekiant giliau įsibrauti ị lietuvių užnugarị.

I sprendimas: III pėstininkų divizija kartu su II pėstininkų divizija priešinasi pagrindinėms lenkų pajègoms (trims divizijoms) pasinaudodamos Neries, Vandžiogalos, Nevėžio gynybinèmis pozicijomis. Ši grupé, palaikydama glaudžius tarpusavio ryšius ir atrèmusi savo dešinịji sparną $\mathfrak{i}$ Nemuną, prireikus surengia atsitraukiamąsias kautynes. I pėstininkų divizija sudaro frontą prieš lenkų supamąją diviziją. O vadovybè, pasirinkusi patogų momentą, nukreipia ị lenkų dešinijj sparną IV pėstininkų diviziją. Jeigu lenkų pagrindinio smūgio prieš Kauno miestą grupè būtų sudaryta iš dviejų pèstininkų divizijų, III péstininkų divizija galètų būti panaudota manevrinei Lietuvos pajègų masei kartu su IV, o galbūt ir su I pèstininkų divizija sudaryti.

b) Lenkai nukreipia savo priešakinio baro pagrindinị smūgị (2-3 pèstininkų divizijas) Jonavos-Ukmergès tarpu bendra Kèdainių kryptimi, o iš Vilniaus Kauno kryptimi pasitenkina veikdama demonstratyviaisiais vienos pèstininkų divizijos veiksmais. Kavalerijos pagrindinès pajègos, kaip ir pirmajame variante, veikia per lietuvių kairijji sparną užnugarį.

II sprendimas: II pėstininkų divizija sudaro frontą prieš lenkus prie Kauno Neries-Nemuno tarpe. Atsižvelgusi ỉ lenkų pagrindinių pajègu puolimo kryptị (Kèdainiai, $\mathfrak{x}$ šiaurę ir pietus nuo jų), III pėstininkų divizija užima barą iš kairès arba iš dešinès, arba užnugaryje I pèstininkų divizijos ir pradeda eventualias atsitraukiamąsias kautynes (su trimis lenkų divizijomis) ar ginasi vietoje. $O$ vadovybé nukreipia ị dešinijji sparną IV diviziją. Susidarius tam tikroms aplinkybėms, III pėstininkų divizija galètų būti panaudota taip pat kaip ir IV pèstininkų divizija ir 
kontrmanevrui atlikti.

c) Lenkai beveik visas šiame fronte veikiančias dalis (keturias pėstininkų divizijas) meta išilgai Vilniaus-Kauno geležinkelio linijos, siekdami greičiau užgrobti Kauną ir nustumti Lietuvos pajėgas nuo Nemuno dešiniojo kranto ị šiaurę. Jų kavalerijos pagrindinès pajègos metamos bendra Kèdainių kryptimi, bandant giliai apeiti lietuvių kairijji sparną.

Sprendimas: II, o galimai ir I pėstininkų divizijos vykdo atsitraukimo i vakarus manevrą, pasinaudodamos tam patogiomis Kauno rajono vietovès ypatybėmis (upėmis ir miškingais krantais). III péstininkų divizija dalyvauja manevre užimdama antrąją Nevėžio ar Dubysos poziciją. Nepanaudotomis pajègomis (IV, o gal ir I pèstininkų divizijomis) vadovybė patogiu momentu manevruoja ị lenkų dešiniji sparną.

d) Lenkai visiškai silpnomis pajègomis (pvz., kavalerija su vienu pèstininkų pulku) prieš Kauną tarp Neries ir Nemuno atliks demonstratyviuosius veiksmus, o savo pagrindines pajègas (3-4 pèstininkų divizijas su kavalerija) mes bendra Ukmergès-Šeduvos kryptimi, palikdami kairèje nedidelę observacinę rinktinę (pvz., vieną pėstininkų diviziją), nukreiptą i Kauno pusę. Šiuo atveju galima spèti, kad šiek tiek aktyviau jie pultų Suvalkijoje žemutinio Nemuno link. Jų kavalerija greičiausia veiktų kairiajame sparne.

Sprendimas: lietuvių pajègos, išskyrus vieną pèstininkų diviziją, paliktą prieš observacinị lenkų korpusą, susirinkusios Kauno rajone, staigiu puolimu mėgina kirsti lenkų komunikacijų liniją maždaug UkmergésŠirvintų tarpo kryptimi.

Toks veikimo būdas turèjo būti naudojamas kiekvieną kartą, kai tik priešo avantiūristinès kariuomenès dalys išprovokuotų lietuvių kariuomenę pulti pakankamai neapsaugotą komunikacijų liniją. Svarbiausia, kad nuo lietuvių puolamosios operacinès krypties iki priešo komunikacijų linijos atstumas būtų ne didesnis kaip nuo priešo pagrindinių pajègų iki lietuvių komunikacijų.

Čia pateiktais samprotavimais paremto pajègų sutelkimo esmé - trijų divizijų išdèstymas: atstumas tarp jų bet kuria iš nagrinejjamų krypčių nebuvo didesnis kaip vienas pėstijos etapas. Pažvelgus ị armijos telkimo eigą matyti užuomazgos dviejų ginamų avangardų, kurie galų gale išauga i I ir II pèstininkų divizijų pajègas. Šių dviejų divizijų sutelktas pajègas saugo priedangos rinktinès, kurios jau nuo pat mobilizacijos pradžios 
turëjo būti pasiruošusios didesnių priešo pajègų akivaizdoje atlikti atsitraukimo manevrą arba surengti atsitraukiamąsias kautynes. III pèstininkų divizija, sutelkta šiek tiek užnugaryje, ir turèjo būti ta jèga, kuri leistų lietuviams lanksčiau taikytis prie kontrmanevro variantų. IV péstininkų divizija būtų ne kas kita, kaip manevrinès pajègos, kuriomis galètų laisvai disponuoti vyr. kariuomenès vadas.

Atsižvelgdama $\mathfrak{i}$ lenkų puolamąsias pajègas ir tų pajègų puolimo kryptis, ị didesnes ar mažesnes priešo padarytas klaidas, lietuvių sutelkta kariuomenè ir būtų veikusi. Viena aišku - Lietuvos kariuomenė priešo puolimą būtų sutikusi būdama gynybinèse pozicijose. Sumanytas puolamasis kontrmanevras būtų atliekamas pirmomis sąlyčio su Lietuvos kariuomenès branduoliu valandomis ar vèliau - tai priklausytų nuo bendros strateginès konjunktūros. Galimas dalykas, kad šis kontrmanevras būtų vykdomas jau surengus kelias atsitraukiamąsias ị vakarus kautynes.

Baigiant šios strateginès hipotezès svarstymą tenka trumpai stabtelèti aptariant dar du klausimus:

a) Suvalkijos prieigų gynyba arba lietuvių strateginio išdėstymo komunikacijų ir dešiniojo sparno apsauga;

b) kairiojo sparno apsauga.

Pirmasis klausimas bus paliestas svarstant priedangos operacijos planą. Pažymètina, kad II pėstininkų divizijos dalys, paskelbus mobilizaciją, jau antrą dieną būtų turejusios Nemuno kairiajame krante nedideles pajegas, kad kartu su kavalerija organizuotai stebètų Nemuno prieigas Kruonio-Darsūniškio bare. Šios operacijos metu gynyba galètų būti pavesta iš priedangos grižtančioms dalims (pvz., Alytaus atskirajam batalionui). O stebèti Nemuną žemiau Kauno ir nedidelëms priešo pajègoms, bandančioms ji forsuoti (ypač kavalerijos dalims), priešintis turètų būti nurodyta I kavalerijos pulkui. Šia proga pabrèžtini du svarbūs klausimai:

a) Nemuno žemiau Kauno (dešiniojo kranto) kuo skubiausias rekognoskavimas;

b) išilgai dešiniojo Nemuno kranto iki pat Vokietijos sienos vieškelio sutvarkymas.

Negalima buvo pamiršti, kad eventualus Nemuno forsavimas galejo būti sèkmingai neutralizuotas tik pavojingame punkte greit sugrupavus nedideles kariuomenès dalis ir kartu parengus atskirą sumanymo objektą. Šiuo atveju vertètų pasakyti, kad lietuvių nereguliariosios kariuomenès 
dalys (šauliai) šiam darbui atlikti galèjo būti sèkmingai panaudotos.

Kairiojo sparno apsauga

Šis klausimas buvo svarstomas atsižvelgiant $\mathfrak{i}$ tris skirtingus mobilizacijos, sutelkimo ir operacijų periodus:

a) Mobilizacijos periodas - I kavalerijos pulkas nuo pat pirmosios mobilizacijos dienos išsidèsto kairiajame Lietuvos pajègų sparne su savo branduoliu tarp Utenos ir Molètų. Jo užduotis - saugoti kairiojo sparno mobilizacijos priedangą, pirmiausia pagalbą teikiant Ukmergès dengiamajai rinktinei. Vienas šio pulko eskadronas turèjo pereiti Ukmergés rinktinès viršininko žinion.

b) Sutelkimo periodas - atsižvelgiant ị lenkų dešiniojo sparno kavalerijos veikimo kryptị, trauktis ị Kèdainių-Panevėžio tarpą, kiek įmanoma palaikant ryšį su Ukmergès rinktine. Šiuo periodu šis kavalerijos pulkas galëjo būti pasiųstas dengti IV pèstininkų divizijos iš Šiaulių geležinkelio transporto.

c) Operacijų periodas - priklausytų nuo bendros operacijų konjunktūros. Pažymètina, jog šis pulkas pirmiausia turèjo būti skiriamas kairiojo sparno saugoti ir ịtrauktas ị manevrinių pajègų sudètị tik to prireikus.

Antroji hipotezè, taikoma, jei lenkai pultu pagrindinèmis pajègomis iš Suvalkijos, sudare atskirą strateginio sumanymo objektą ir, turint omenyje III lenkų korpuso dalių tuometę dislokaciją ir bendrą politinę konjunktūrą, tuo metu lietuviams nebuvo aktuali ${ }^{132}$.

Priedangos operacijos sumanymas

Priedangos tikslas buvo apsaugoti nuo priešo veiksmų detaliai suplanuotą, gerai apgalvotą taikos metu parengtos kariuomenès mobilizaciją ir sutelkimą. Sumanytos hipotezės sąlygomis priedangos dalys galèjo būti itrauktos ị kautynes su stipresniu priešu jau nuo pat pirmosios mobilizacijos dienos. İsakymą gavusios Lietuvos priedangos dalys turèjo būti pasirengusios per tris valandas išvykti i jau taikos metu numatytas pozicijas.

Priedangos dalių kovinis potencialas turèjo būti visą laiką palaikomas, kad atitiktų karo meto lygi, t. y. kad vadinamoji priedangos dalių „, išstatymo“ operacija galètų būti atlikta faktinių pajègų (pulkas - 3 batalionai su kautynèms reikalingomis ūkio dalimis). Šioje srityje negalëjo būti jokių kompromisų (pvz., du batalionai vietoj trijų).

Rengiant priedangos operacijos planą pirmiausiai tenka susidurti su 132 Ten pat, 1. 36-44. 
šiais klausimais: kokias pajegas tam panaudoti, kokio sulaikomojo potencialo iš priedangos dalių galima tikètis ir, pagaliau, kaip ilgai šios dalys privalo veikti?

Kaip ir kitais atvejais, čia taip pat svarbu vadovautis vienu iš pagrindinių karo meno dèsnių - pajègų tausojimo principu, kuris verčia būti labai atsargius, ypač kai pajègos yra negausios. Operacijų skyriaus nuomone, būtent dèl to negalima prarasti daugiau kaip 1/3 dalių (neskaitant kavalerijos), t. y. keturių iš dvylikos veikiančiosios kariuomenès pėstininkų pulkų.

Priedangos dalių sulaikomoji geba priklausys nuo jų kovinio potencialo ir kaip bus išnaudoti svarbesni ir ne tokie svarbūs vietovės ypatumai, galų gale, nuo priešo puolamųjų pajègų dydžio:

a) Priedangos dalių kovinis potencialas, kitaip tariant, tų dalių kokybė, priklausys nuo jų organizacijos, geresnio ar blogesnio materialinio aprūpinimo (pirmiausia - pakankamai gausios artilerijos), taip pat nuo viršininkų gebejimų. Visų kariuomenių priedangos dalys paprastai yra geriausiai tvarkomos komplektavimo, aprūpinimo ir parengimo prasme. Buvo konstatuota, kad Lietuvoje, deja, iki tol šiems reikalavimams nebuvo skiriama pakankamai dèmesio.

b) Sprendžiant vietovès ypatumų klausimą reikejjo vadovautis principu, kad dengiamosios kariuomenès dalys jau taikos metu turètų užimti nuodugniai rekognoskuotas pozicijas kuo arčiau demarkacijos linijos, ir dar turèti omenyje, kad 3-4 valandų joms prireiks ten susirinkti ir pasiruošti veikti. Todèl jos geriausiu atveju turèjo būti nutolusios nuo Lietuvos ir Lenkijos demarkacijos linijos (nuo taikos meto kareivinių) 25-30 km (per kavalerijos žygio etapą) atstumu. Priešingu atveju jos, dar nespejusios pasiruošti, galejjo būti priešo užpultos. Kalbant apie priedangos dalių pasirengimą kovai reikia pabrèžti, kad ši sąvoka apima ne tik mobilizacinę parengti, dalies išvedimą iš kareivinių rajono, bet ir toms dalims nurodytos pirmosios pozicijos užèmimą.

Dèl vietovès ypatybių išnaudojimo pasakytina, kad priedangos dalys, kurios paprastai buvo silpnesnès, privalèjo ypač atkreipti dèmesi $\mathfrak{i}$ patogias gynybai geografines ribas (upelius, miškus, sunkiai pereinamas vietas). Nagrinėdamos pozicijos ypatumus taktiniu požiūriu, priedangos dalys turèjo žiūrèti, kad geografinès kliūtys būtų prieš ginamą frontą.

c) Pajėgų santykis: kuo stipresnès priešo pajègos spaudžia, tuo, savaime aišku, priedangos dalims sunkiau veikti. Priedangos dalių judrumas 
iš dalies atsveria jų negausumą, todèl ị tai reikèjo atsižvelgti sprendžiant organizacinius priedangos dalių klausimus.

Negalima pamiršti, kad priedangos dalys pirmiausia turejo vengti susikompromituoti. Dèl to dažniausiai turèjo organizuoti atsitraukimo manevrą, o kartais ir atsitraukiamąsias kautynes. Priedangos dalies vado sumanumas ir iniciatyva čia igyja didelę reikšmę. Priedangos dalių tikslas galèjo būti pasiektas, jei stipresnès priešo pajègos būtų priverstos, užuot atlikusios ịprastą dienos žygi (vieno etapo), ịveikti tik jo pusę $(12-15 \mathrm{~km})$. Taigi, priedangos dalys pirmiausia siektų laimèti laiko ir taip sudaryti sąlygas pagrindinèms pajègoms tvarkingai baigti mobilizacijos ir susitelkimo operacijas.

Operacijų skyriaus nuomone, Lietuvos kariuomenei a priori pasirengti mobilizacijai reikètų 3, susitelkti - 2, o iš viso - 5 dienų. Parinktos susitelkimo zonos periferija nuo demarkacijos linijos (išilgai spejjamų puolimo krypčių) būtų:

nuo Kèdainių I pèst. divizijos zonos - apie $70 \mathrm{~km}$ - 2,5-3 etapai;

nuo Kauno II pèst. divizijos zonos Vilnijos link - apie $60 \mathrm{~km}-2,5$ etapo;

nuo Kauno II pèst. divizijos zonos Suvalkijos link - apie $90 \mathrm{~km}-$ 3,5-4 etapai;

nuo Šiaulių IV pèst. divizijos zonos - $150 \mathrm{~km}-6$ etapai.

Atmetus priedangos tiesioginị apsaugos ruožą, liktų:

nuo Kèdainių I pèst. divizijos zonos - $45 \mathrm{~km}$ - 1,5 etapo;

nuo Kauno II pèst. divizijos zonos Vilnijos link - $35 \mathrm{~km}-1,5-3,5$ etapo;

nuo Kauno II pėst. divizijos zonos Suvalkijos link - $65 \mathrm{~km}-2,5-3$ etapo;

nuo Šiaulių IV pèst. divizijos zonos - $125 \mathrm{~km}$ - 5 etapai.

Staiga kilus konfliktui, visais požiūriais keblioje situacijoje būtų atsidūrusi Ukmergès-Veprių dengiamoji rinktinè, nes jai būtų tekę:

1. laikytis $45 \mathrm{~km}$ atstumu krašto gilumoje mažiausiai 4 dienas;

2. ịveikti per dieną vidutiniškai 11-12 km (didžiausias reikalavimas);

3. atsižvelgti i priešo dešiniojo sparno kavalerijos dalis;

4. veikti neturint patikimesnès sparnų atramos.

Šiaulių rajone IV pėstininkų divizijos mobilizacija ir sutelkimas jau vien dèl atstumo buvo saugūs. 
Savaime aišku, kad Lietuvos kariuomenès mobilizacija ir sutelkimas dèl skubos turejo atitikti bent pagrindinius vadovybès reikalavimus. Operacijų skyriaus nuomone, kaip tik ir reikejo rasti tokią sistemą, kad mobilizacija būtų atlikta per tris, sutelkimas - per dvi dienas.

Priedangos dalių išdèstymas

Nustačius pagrindinius Lietuvos kariuomenès priedangos organizavimo duomenis, kilo klausimas ir dèl priedangos dalių išdèstymo: numatyta iš keturių pėstininkų pulkų (12-13 batalionų) vieną pulką (3-4 batalionus) skirti Suvalkijai, likusius tris - Vilnijai dengti. Šis sumanymas kaip tik atitiko Operacijų skyriaus bendrą strateginę koncepciją.

Nagrinèjant priedangos išdèstymą teko susidurti su spejjamomis lenkų puolimo kryptimis (apie tai anksčiau jau buvo rašyta). Visa tai aptarus, kilo klausimas: kur galètų būti nukreiptas pagrindinis priešo smūgis - aukščiau ar žemiau Jonavos? Tai buvo pagrindinis samprotavimų motyvas, privertęs kariuomenès vadovybę priimti atitinkamą priedangos išdèstymo planą:

vienas pėstininkų pulkas, viena artilerijos grupè ( 3 baterijos) ir vienas kavalerijos eskadronas - Ukmergèje;

vienas péstininkų pulkas, viena artilerijos grupè ( 3 baterijos) ir vienas kavalerijos eskadronas - Jonavoje;

vienas péstininkų pulkas, viena artilerijos grupé (3 baterijos) ir vienas kavalerijos eskadronas - Kaišiadoryse;

vienas pėstininkų pulkas, viena artilerijos grupè ( 3 baterijos) ir vienas kavalerijos eskadronas - Marijampoleje;

vienas atskiras pėstininkų batalionas su dviem kavalerijos eskadronais ir viena baterija - Alytuje;

vienas kavalerijos pulkas su raitąja baterija - Vilkaviškyje.

Siūlant tokị dislokacijos sumanymą atsižvelgta ir ị dalių esamose kareivinèse sutalpinimą.

Vilniaus krypties priedanga

Šios krypties priedangos pajègos buvo grupuojamos Ukmergès-Jonavos-Kaišiadorių trikampyje. Nuo Jonavos centrinio punkto iki kraštinių šios dispozicijos sparnų buvo tik vienas péstijos etapas.

Šios sistemos privalumai:

a) atsižvelgiant $\mathfrak{i}$ pagrindinę lenkų puolimo kryptị, Jonavos rinktinè nuo antrosios puolimo dienos galèjo būti mesta arba Kaišiadorių- 
Kauno, arba Ukmergès-Veprių dengiamosioms rinktinèms sustiprinti. Šiuo atveju numatyta, jog Jonavos rinktinè galètų sudaryti antrąji Ukmergès-Veprių gynybinị ešeloną;

b) turint omenyje lietuvių pajègų susitelkimo zonos skersmenị, Jonavos rinktinè kaip tik būtų atlikusi svarbų šios sistemos dviejų šiek tiek ekscentrinių atsitraukimo krypčių jungiamąji vaidmenį;

c) bus ginamas labai svarbus lietuviams Jonavos punktas (atstumas nuo jo iki demarkacijos linijos - vos $40 \mathrm{~km}$ );

d) Ukmergès-Veprių dengiamoji rinktinè prireikus tikrai galejjo savo dešiniji sparną atremti ị Jonavos rajoną.

Suvalkijos krypties priedanga

Galima jos organizavimo tvarka:

a) Mobilizacijos ir telkimo laikotarpiu Marijampolès rinktinè trauktųsi išilgai Marijampolès-Kauno plento. Prienų-Veiverių aukštumoje šios rinktinès vadas koordinuotų ir tolesnius Alytaus rinktinès veiksmus.

Alytaus rinktinè trauktųsi išilgai Alytaus-Kauno plento, o jos kavalerijos dalys veiktų dešiniajame Nemuno krante. Be to, šios kavalerijos dalys (nuo pat karo veiksmų pradžios) susprogdintų kelis svarbius Vilniaus-Gardino geležinkelio punktus.

Vilkaviškyje esantis kavalerijos pulkas, sumaniai naudodamasis patogiomis stebejjimui ir gynybai skersinėmis ribomis, gins Vilkaviškio-Šakių kryptị link žemutinio Nemuno.

b) Operacijų laikotarpiu kairiajame Nemuno krante šalia Kauno Marijampolès rinktinè susijungs su savo divizijos pagrindinėmis pajègomis.

Atsitraukusi Alytaus rinktinè pereis II pėstininkų divizijos vado žinion. Vilkaviškyje esantis kavalerijos pulkas (visas ar tik jo dalis) priešinsis priešo kavalerijos mėginimams persikelti per Nemuną.

Tuo metu buvo labai svarbu tinkamai išspręsti kavalerijos panaudojimo klausimą. Dèl to reikejjo turèti:

prie kiekvieno pėstininkų pulko bent po vieną žvalgų komandą;

prie kiekvienos pėstininkų divizijos po vieną gerą eskadroną;

3 kavalerijos pulkus (jau taikos metu).

Mobilizacijos sutelkimo periodas

Jo metu numatyta:

prie kiekvienos iš keturių dengiamųjų rinktinių turèti po vieną kavalerijos eskadroną (iš viso keturis: trys iš jų būtų perkelti iš I, II ir III, 
o ketvirtas - iš armijos kavalerijos (ulonų) pulko;

dešiniojo sparno ir užnugario apsaugai užtikrinti suformuoti naują pulką (3-4 eskadronus);

prie Alytaus rinktinès turèti du ulonų pulko eskadronus;

kairiojo sparno apsaugai užtikrinti pasitelkti husarus.

Tada šiuo periodu vyr. kariuomenès vado dispozicijoje liktų vos vienas eskadronas. Visa kavalerija aktyviai veiktų. Visos sudėties ulonų pulkas pereitų $\mathfrak{j}$ kariuomenès manevrinių pajègų rezervą.

Šauliai ir kitos nereguliariosios pajègų dalys eitų užnugario tarnybą (saugotų kelius, tiltus, telefono-telegrafo linijas, sandèlius ir kt.).

Kovos uždaviniai

Veiktų dengiamų rinktinių tarpuose (Pravieniškių ir Kazlų Rūdos miškuose), dalyvautų ginant Nemuno prieigas.

Šaulių mokymo plane jau taikos metu turëjo būti atsižvelgta ị šiuos samprotavimus $^{133}$.

\section{Faktinè Lietuvos pajègų padètis}

Mobilizacija

Pažvelgus ị tuo metu galiojusị mobilizacijos tvarkaraštị Nr. 5 matyti, jog Lietuvos kariuomenès rikiuotès dalys, remiantis tam tikrais samprotavimais sutelktos ị mišrias divizijas, jau buvo baigusios mobilizaciją. Toliau lentelèje pateikti su tuo susiję duomenys.

${ }^{133}$ Ten pat, 1. 45-51. 
Lietuvos kariuomenès gynybos planai ir priemonès galimai lenkų agresijai atremti 1921-1937 m.

\begin{tabular}{|c|c|c|c|}
\hline Dalių pavadinimai & $\begin{array}{c}\text { Mobilizacijos } \\
\text { vieta }\end{array}$ & $\begin{array}{l}\text { Mobilizacijos } \\
\text { trukmé }\end{array}$ & Pastabos \\
\hline $\begin{array}{l}\text { I pėst. divizijos štabas } \\
1 \text { pèst. pulkas } \\
3 \text { pèst. pulkas } \\
4 \text { pèst. pulkas } \\
2 \text { artilerijos pulkas }\end{array}$ & $\begin{array}{l}\text { Panevėžys } \\
\text { Ukmergé } \\
\text { Panevėžys } \\
\text { Panevėžys } \\
\text { Kėdainiai }\end{array}$ & $\begin{array}{l}3 \text { d. } 13 \text { val. } \\
3 \text { d. } 16 \text { val. } \\
4 \text { d. } 16 \text { val. } \\
3 \text { d. } 4 \text { val. } \\
3 \text { d. } 16 \text { val. }\end{array}$ & $\begin{array}{l}\text { Pagal hipotezę } \\
\text { numatytas ilgiausias } \\
\text { mobilizacijos } \\
\text { laikotarpis - } 3 \text { dienos } \\
\text { Šio pulko viena } \\
\text { baterija mobilizuojasi } \\
\text { Klaipeddoje per } 3 \mathrm{~d} \text {. } \\
12 \text { val. }\end{array}$ \\
\hline $\begin{array}{l}\text { II pèst. divizijos } \\
\text { štabas } \\
2 \text { pèst. pulkas } \\
5 \text { pèst. pulkas } \\
12 \text { pėst. pulkas } \\
3 \text { artilerijos pulkas }\end{array}$ & $\begin{array}{l}\text { Kaunas } \\
\text { Kaunas } \\
\text { Kaunas } \\
\text { Kaunas } \\
\text { Kaunas }\end{array}$ & $\begin{array}{l}3 \text { d. } 24 \text { val. } \\
5 \text { d. } 12 \text { val. } \\
4 \text { d. } 12 \text { val. } \\
5 \text { d. } 24 \text { val. } \\
4 \text { d. } 20 \text { val. }\end{array}$ & \\
\hline $\begin{array}{l}\text { III pėst. divizijos } \\
\text { štabas } \\
9 \text { pèst. pulkas } \\
10 \text { pèst. pulkas } \\
12 \text { pést. pulko štabas } \\
\text { I/11 } \\
\text { II/11 } \\
\text { III/11 } \\
1 \text { artilerijos pulkas }\end{array}$ & $\begin{array}{l}\text { Kaunas } \\
\text { Marijampolè } \\
\text { Šiauliai } \\
\text { Kaunas } \\
\text { Ukmerge் } \\
\text { Kaunas } \\
\text { Marijampolè } \\
\text { Kaunas }\end{array}$ & $\begin{array}{l}4 \text { d. } 12 \text { val. } \\
4 \text { d. } 12 \text { val. } \\
5 \text { d. } 10 \text { val. } \\
5 \text { d. } 12 \text { val. } \\
3 \text { d. } 21 \text { val. } \\
5 \text { d. } 12 \text { val. } \\
3 \text { d. } 18 \text { val. } \\
5 \text { d. } 12 \text { val. }\end{array}$ & \\
\hline $\begin{array}{l}\text { IV pèst. divizijos } \\
\text { štabas } \\
6 \text { pèst. pulkas } \\
7 \text { pėst. pulkas } \\
8 \text { pèst. pulkas } \\
4 \text { artilerijos pulkas }\end{array}$ & $\begin{array}{l}\text { Šiauliai } \\
\text { Klaipèda } \\
\text { Klaipèda } \\
\text { Šiauliai } \\
\text { Vilkaviškis }\end{array}$ & $\begin{array}{l}6 \mathrm{~d} .14 \text { val. } \\
4 \text { d. } 21 \text { val. } \\
4 \text { d. } 3 \text { val. } \\
3 \text { d. } 20 \text { val. } \\
4 \text { d. } 6 \text { val. }\end{array}$ & $\begin{array}{l}\text { Viena šio pulko } \\
\text { baterija mobilizuojasi } \\
\text { Alytuje per } 3 \mathrm{~d} \text {. } 3 \text { val. }\end{array}$ \\
\hline $\begin{array}{l}\text { Armijos dalys } \\
\text { Husarai } \\
\text { Ulonai } \\
\text { Mokomasis } \\
\text { eskadronas }\end{array}$ & $\begin{array}{l}\text { Kaunas } \\
\text { Alytus } \\
\text { Alytus }\end{array}$ & $\begin{array}{l}4 \text { d. } 21 \text { val. } \\
3 \text { d. } 20 \text { val. } \\
2 \text { d. } 24 \text { val. }\end{array}$ & \\
\hline
\end{tabular}


Kol kas neịtraukiant visų šalies kariuomenès vienetų (divizijų pagalbinių ginklų rūšių, divizijų tarnybų, kariuomenès dalių ir kt.) konstatuota, kad:

a) artimiausios Lietuvos rytinès periferijos dalys, numatytos priedangai sudaryti: 1-asis, 5-asis ir 9-asis pėstininkų pulkai, ulonai ir mokomasis eskadronas - mobilizavosi tik 3-ios dienos 16 val., 4-os dienos 12 val., 3-ios dienos 20 val., 2 -os dienos 24 val.;

b) priedangos dalinių veikimo zonoje - Marijampolëje, Ukmergèje ir Vilkaviškyje - mobilizavosi: 11-ojo pėstininkų pulko III batalionas 3-ios dienos 18 val., 11-ojo pèstininkų pulko I batalionas - iki 3-ios dienos 21 val., 4-asis artilerijos pulkas (niekieno nedengiamas) - iki 4-os dienos 6 val.

Pagrindinių jègų telkimas

Lietuvos pajègų sutelkimo sumanymui igyvendinti reikejjo, kad didelès kariuomenès dalys būtų baigtos pervežti:

\begin{tabular}{|c|c|c|c|c|}
\hline Divizijos & $\begin{array}{c}\text { Sutelkimo } \\
\text { vieta }\end{array}$ & Rinkimosi būdas & $\begin{array}{l}\text { Sutelkimas } \\
\text { baigiamas }\end{array}$ & Pastabos \\
\hline I pèst. divizija & $\begin{array}{l}\text { Kèdainių } \\
\text { rajone }\end{array}$ & Žygio tvarka & 6 d. 16 val. & \\
\hline II pèst. divizija & Kaune & Žygio tvarka & $6 \mathrm{~d} .12$ val. & \\
\hline III pèst. divizija & $\begin{array}{l}\text { Ariogalos } \\
\text { rajone }\end{array}$ & Geležinkeliu ir & $6 \mathrm{~d} .12$ val. & \\
\hline IV pèst. divizija & Šiauliuose & Geležinkeliu & 5 d. 8 val. & \\
\hline
\end{tabular}

P. S. Pagal Operacijų skyriaus hipotezę susitelkti daugiausia buvo skirtos 2 dienos.

Apibendrinęs faktinę Lietuvos kariuomenès padètị ir pritaikęs ją šiam operatyviniam sumanymui, Operacijų skyrius padarẻ labai liūdnas išvadas:

1. Daugiau kaip 4,5 dienos nuo mobilizacijos paskelbimo Lietuvos pajègu priedangos sistema vis dar buvo mobilizuojama ir, savaime suprantama, jokių priedangos operacijų atlikti negalejo.

2. Nelaimejjus 4-5 dienų, kol lenkai neperžengė demarkacijos linijos, Lietuvos pajègų mobilizacija ir, žinoma, sumanyta operacija (pagal 
mobilizacijos tvarkaraštị Nr. 5) būtų neišvengiamai sukompromituota.

Iš susidariusios padèties galèjo būti išeitis:

pripažinti, kad lenkai gali staiga lietuvius pulti, jiems mobilizacijos dar nepaskelbus;

būti tvirtai nusistačius kariauti organizuotą, planingą gynybinị karą.

Operacijų skyriaus nuomone, Lietuvą ginti reikètų pasirinkus vieną iš dviejų alternatyvų:

a) atsisakyti šiame sumanyme pateikto plano ir ieškoti naujų operatyvinių sumanymų arba

b) bendromis jẻgomis skubiai ir iš esmès tvarkyti kariuomenę - pirmiausia jos mobilizacijos ir telkimo sistemą.

Priedangos klausimas turejjo būti tučtuojau sprendžiamas pagal pateiktą darbų planą:

1. Galutinis mobilizacijos operacijos sumanymo svarstymas ir taikos meto dislokacija.

2. Kovų tvarkos galutinis nustatymas numačius visas pagalbines dalis ir tarnybas.

Šis darbas turejjo būti atliekamas vadovaujantis pagrindiniu mobilizacijos operacijos planu, o ne vien administraciniais biudžeto skaičiavimais, kaip iki tol dažnai buvo daroma.

1. Svarstant Lietuvos pajėgų kovų tvarką reikejjo nepamiršti, kad pirmiausia jos privalo turèti:

a) 4 tikrus divizijos artilerijos pulkus, kiekvieną sudarytą iš 12 baterijų (po vieną artilerijos grupę kiekvienam priedangos pulkui);

b) 1 armijos toliašaudès artilerijos pulką (sudarytų $155 \mathrm{~mm}$ patrankos ir haubicos);

c) pakankamai kavalerijos (12-13 žvalgų komandų, 4 divizijos eskadronus ir 3 kavalerijos pulkus);

d) pèstijos palydos baterijų.

2. Priedangos dalių organizavimo klausimas (kovos ir vadovybès priedangos dalys gerokai skirsis nuo kitų dalių).

3. Doktrinos nustatymas. Operacijų skyriaus nuomone, principai, kodifikuoti įvairiuose statutuose, nustato tik vieną iš galimų kariuomenès veikimo formų. Mūsų doktrinos sąvoka ir visa karinio mokymo programa turejo būti pagrịsta plačiuju frontų idèja.

4. Ivairių kariuomenès ešelonų galutinè vadovybès organizacija 
(vyriausioji vadovybė - būrio vado komandavimo grupè).

5. Ginklų ir techninių medžiagų ísigijimo planas.

Šis klausimas keliamas programos pabaigoje, nes su juo glaudžiai susiję kiti jos punktai.

Operacijų skyriaus ịsitikinimu, tik atsakingai sudarytas, nuodugnus mobilizacijos operacijų planas galètų išvaduoti negausią šalies kariuomenę iš chaoso, kuris tęsèsi 8 metus ${ }^{134}$.

Operacijų skyriaus viršininko plk. B. Jakučio iniciatyva parengto ir Gen. štabo valdybos viršininkui plk. P. Kubiliūnui nusiųsto projekto idèja, jo autoriaus nuomone, paremta viena iš blogiausių krašto gynybinių hipotezių, buvo pakankama priežastis Lietuvos gynimo klausimui nuodugniai apsvarstyti. Pasak plk. B. Jakučio, šis sumanymas neišvengiamai turejo būti priderintas prie Lietuvos eventualaus KARO PLANO, kuri rengti, savaime aišku, teko jau ne tik Operacijų skyriui.

Pabrèždamas šio sumanymo išvadų svarbą, plk. B. Jakutis pažymėjo, jog reikia skubiai jị apsvarstyti, nes, staiga kilus konfliktui, Lietuvos ginkluotųjų pajègų karinis potencialas „neleistų dargi net svajoti apie naudingo karo galimumus ${ }^{{ }{ }_{135}}$.

Praejus trims dienoms po minèto sumanymo išsiuntimo Gen. štabo valdybos viršininkui, kariuomenès vadas gen. S. Žukauskas atkreipè visų trijų karo apygardų viršininkų dėmesị ị tai, kad ne visai aiškus ir agresyvus Lenkijos nusistatymas Lietuvos atžvilgiu. Jis gali pasireikšti:

1. aktyviais lenkų gaujų veiksmais ịvairiose Lietuvos teritorijos vietose;

2. reguliariųjų arba nereguliariųjų dalių invazija ị šalies teritoriją.

Visa tai vertè lietuvius labai susirūpinti. Šiuo atveju kariuomenès vadas nurodè neatidèliojant Marijampoleje, Alytuje, Kaišiadoryse ir Ukmergèje prie atitinkamų kariuomenės dalių, o kur jų nebuvo - prie karo komendantūrų sudaryti decentralizuotus pasienio zonos štabus ir jiems pavesti organizuoti teritorijos priedangą, ịtraukiant pasienio apsaugą, šaulių būrius ir kariuomenès dalis.

Priedangos dalims, panašiu būdu organizuotiems štabams vadovaujant, pirmiausia nurodyti užkirsti kelią bet kokiai invazijai.

Lenkijos reguliariųjų pajègų dalims puolant, Lietuvos periferijos dalys

134 Ten pat, 1. 52-55.

${ }^{135}$ Operacijų skyriaus viršininko gen. št. plk. B. Jakučio 19271126 slaptas asmeninis raportas Nr. 21934 Generalinio štabo valdybos viršininkui, ten pat, l. 56. 
automatiškai galèjo pradèti vykdyti paskelbtos mobilizacijos ir sutelkimo priedangą. Naujai sudarytas lauko štabas (viršininkas - gen. št. plk. P. Kubiliūnas) turèjo neatidèliodamas parengti atitinkamas direktyvas.

Tuo metu buvo numatytos ir periferijos dalių veikimo zonos:

2. Marijampolès pasienio zonos štabo - Vokietijos siena-GaliniaiRudamina-Krosna (visi punktai imtinai);

3. Alytaus - Galiniai-Rudamina-Krosna-Aukštadvaris-Stakliškès (visi punktai imtinai);

4. Kaišiadorių - Aukštadvaris-Stakliškès (imtinai) ir dešinysis Neries krantas;

5. Ukmergès - dešinysis Neries krantas-Latvijos siena.

Pasienio zonų štabų veiklą turejo tiesiogiai kontroliuoti Kaune esantis lauko štabas ${ }^{136}$.

\section{Kariuomenès vado gen. S. Žukausko \\ 1927 m. lapkričio 30 d. direktyva Nr. 21962}

Bendromis kariuomenès vado gen. S. Žukausko, lauko štabo viršininko gen. št. plk. P. Kubiliūno ir Operacijų skyriaus viršininko gen. št. plk. B. Jakučio pastangomis 1927 m. lapkričio $30 \mathrm{~d}$. buvo parengta operatyvinè direktyva Nr. 21962. Joje buvo pabrèžta, kad bendra susiklosčiusi politinẻ konjunktūra verčia kiekvieną akimirką laukti Lietuvos priešų agresyvių žygių. Visapusiškai padètị išnagrinejjus, prieita prie bendros išvados, kad šiuo laikotarpiu Lietuvai pirmiausia grèsmė kyla iš Lenkijos. Surinkus žinias ir tinkamai ịvertinus visus konjunktūros veiksnius, spèta, kad lenkų agresija tuo metu galètų pasireikšti dviem formomis:

1. lenkų nereguliariụjų dalių (vadinamųjų „sukilèlių“, „strzelcais“ sustiprintų gaujų ar civiliškai perrengtos kariuomenès) įsiveržimas ị šalies teritoriją;

2. nereguliariųjų dalių akcija, kurią čia pat galèjo paremti reguliariosios kariuomenès dalys.

Minètoje direktyvoje teigiama, kad lietuviai, nepasirengę užkirsti kelio nereguliariosios kariuomenès dalių i̇ Lietuvos teritoriją ịsiveržimui, neturètų pamiršti, jog tam skirtos dalys privalès vykdyti šalies pajègu

${ }^{136}$ Kariuomenès vado gen. S. Žukausko 19271129 slaptas asmeninis raštas Nr. 21956 I-III karo apygardų viršininkams, LCVA, f. 929, ap. 3, b. 594, 1. 1. 
eventualios mobilizacijos ir sutelkimo priedangą (antroji agresijos forma).

Nors dvi minètos agresijos formos iš esmès atitiko skirtingas strategines fazes, Lietuva, gresiant konfliktui, privalejo kiekvieną akimirką būti visiškai pasirengusi abiem - sklandžiai ir planingai pereiti nuo vienos strateginès konjunktūros prie kitos.

Savaime suprantama, kad pasirengimas pirmai fazei jokiu būdu neturejjo kliudyti pereiti prie antros.

Lenkijos nereguliariụjų pajėgų dalių ísiveržimui ị Lietuvos teritoriją užkirsti kelią kariuomenès vadas gen. S. Žukauskas pavedè šioms periferijos kariuomenès dalims: 9-ajam pėstininkų pulkui, 2-ajam ulonų pulkui, 5-ajam ir 1-ajam pėstininkų pulkams (sustiprintiems). Čia išvardytos ir sustiprintos kariuomenès dalys nuo direktyvos gavimo dienos turejjo būti vadinamos:

9-asis pèstininkų pulkas - Marijampolès grupe;

2-asis ulonų pulkas - Alytaus grupe;

5-asis pėstininkų pulkas - Kaišiadorių grupe;

1-asis péstininkų pulkas - Ukmergès grupe.

Šioms kariuomenès dalims operatyvine prasme tapo visiškai pavaldžios ir visos atitinkamų barų pasienio apsaugos dalys, taip pat visi tų barų šaulių būriai. Tokie buvo duoti nurodymai.

Minètos priedangos grupès turèjo būti sudarytos ir jų padaliniai galutinai išdèstyti per dvi fazes:

I fazè:

priedangos grupių štabų galutinis organizavimas;

vietinès reikšmès pagalbinių dalių galutinis organizavimas (pasienio apsauga, šauliai);

priedangos grupių sustiprinimas kai kuriomis dalimis vietoje;

priedangos grupėms sustiprinti skirtų likusių dalių visiškas parengimas. II fazè:

likusių dalių prijungimas prie priedangos grupių.

Ši direktyvos dalis buvo susijusi tik su nereguliariųjų pajègų dalių vykdomo puolimo hipoteze.

Grupių suskirstymas barais

Marijampolès baras - nuo Vokietijos sienos iki Galinių-RudaminosKrosnos (visi punktai imtinai);

Alytaus baras - nuo Marijampolès grupès baro linijos iki Aukštadvario- 
Stakliškių (visi punktai imtinai);

Kaišiadorių baras - nuo Alytaus grupès baro linijos iki kairiojo Neries kranto;

Ukmergès baras - nuo kairiojo Neries kranto iki sienos su Latvija ${ }^{137}$.

Priedangos grupių uždaviniai

Silpnesnès sudèties prasiveržusios lenkų gaujos turèjo būti neatidèliojant likviduotos. Stipresnèms priešo pajègoms spaudžiant, atitinkamų priedangos grupių vadai gavo užduotị sulaikyti toliau ị šalies gilumą besiskverbiančias gaujas ir kartu išsiaiškinti svarbesnes jų veržimosi kryptis ir sudètị.

Priedangos grupių vadai, vietoje susipažinę su aplinkybėmis, privalèjo pateikti konkrečius sumanymus šiai direktyvai patobulinti, turint galvoje, jog pasienio apsaugos dalys (galimai šauliais sustiprintos), priešo gaujoms spaudžiant, trauksis tam tikromis iš anksto nustatytomis kryptimis $\mathfrak{i}$ taip pat iš anksto numatytus punktus, kur jų veikimas toliau turès būti derinamas su šaulių ar kariuomenès būrių veiksmais.

Priešui ị Lietuvos teritoriją dar neįsiveržus, priedangos grupių vadai turèjo sutrukdyti jo kariuomenès būriams ižžengti i $5 \mathrm{~km}$ nuo demarkacijos linijos savo puseje zoną.

Šių grupių sudètis ir užduotys:

1. Marijampolès priedangos grupè: grupès štabas, 9-ojo pėstininkų pulko III batalionas, 4-ojo artilerijos pulko 1-oji lauko patrankų baterija, ulonų pulko I eskadronas. Kalvarijos punktą jau iš anksto privalèjo užimti vienas péstininkų būrys, ginkluotas 2 sunkiaisiais kulkosvaidžiais.

2. Alytaus priedangos grupè: grupès štabas, 2-ojo ulonų pulko likę eskadronai, 4-ojo artilerijos pulko 11-oji lauko patrankų baterija. Seiriju ir Daugu punktai iš anksto turèjo būti užimti kavalerijos būrio, ginkluoto 2 lengvaisiais kulkosvaidžiais.

3. Kaišiadorių priedangos grupè: grupès štabas, 5 -asis pèstininkų pulkas, 3-iojo artilerijos pulko 1-oji lauko patrankų baterija, vienas husaru eskadronas. Nurodyta Mijaugonių punktą iš anksto užimti vienam pèstininkų būriui, ginkluotam 2 sunkiaisiais kulkosvaidžiais.

4. Ukmergès priedangos grupè: grupès štabas, 1-asis pèstininkų pulkas, 2-ojo artilerijos pulko viena lauko patrankų baterija, vienas husarų

${ }^{137}$ Kariuomenès vado gen. S. Žukausko 19271130 slapta asmeninė operatyvinė direktyva Nr. 21962, ten pat, 1. 1 ir 3. 
eskadronas. Viesų (prie Ukmergès-Širvintų vieškelio) ir Utenos punktus nurodyta užimti: pirmajji - vienam péstininkų būriui, ginkluotam 2 sunkiaisiais kulkosvaidžiais, antrąji - komendantūrai, sustiprintai vienu péstininkų būriu, ginkluotu 2 sunkiaisiais kulkosvaidžiais.

Visų šių priedangos grupių vadai, konkrečius duomenis patvirtinus kariuomenès vadui, turèjo užimti tik minètus punktus.

Vykdymo tvarka

$\underline{\text { I fazè }}$

1. Priedangos grupių štabų galutinị organizavimo procesą turèjo prižiūrèti atitinkamų karo apygardų viršininkai. Priedangos grupių štabai (daugiausia 4 karininkai) pradedami organizuoti gavus šią direktyvą.

Kaišiadorių grupès štabas turèjo išvykti ị jam skirtą vietą iš karto baigęs organizuotis. Štabams reikalingą informaciją privalejo teikti atitinkami pulkai. Apie štabų organizavimą buvo numatyta pranešti kariuomenès vadui.

2. Organizuodami vietinès reikšmès pagalbines dalis (pasienio apsaugą, šaulius), priedangos grupių vadai turèjo neatideliodami išsikviesti jiems pavestų barų atitinkamus pasienio apsaugos viršininkus ir šaulių rinktinių vadus pasikonsultuoti.

3. Neatideliojant stiprinant priedangos grupes:

vienas ulonų eskadronas privalëjo iš Alytaus būti pasiųstas Marijampolès grupès vado žinion,

4-ojo artilerijos pulko viena lauko patrankų baterija (kovinès sudèties) - Marijampolès priedangos grupès vado žinion.

Siunčiamų dalių rengimas žygiui ir pats žygis turèjo būti kuo mažiau pastebimas.

Likusių dalių priedangos grupėms sustiprinti parengimas

Kaišiadorių grupè: 5-asis pėstininkų pulkas buvo paliktas Kaune, tačiau kiekvieną akimirką turèjo būti pasiruošęs geležinkeliu vykti ị Kaišiadoris. 3-iojo artilerijos pulko viena lauko patrankų baterija, išplèsta iki kovinès sudèties ir visiškai pasirengusi kovai, taip pat palikta Kaune, kol bus gautas atskiras įsakymas. 1-asis husarų eskadronas pasirengęs lieka Kaune iki atskiro ịsakymo.

Ukmergès grupé: 2-ojo artilerijos pulko viena lauko patrankų baterija, išplèsta iki kovinès sudèties, lieka Kaune iki atskiro ịsakymo.

Visi šiame punkte išvardyti parengiamieji darbai atliekami taikos 
meto resursais.

Artilerijos, kavalerijos ir karo apygardų viršininkai turejjo skubiai pateikti kariuomenès vadui savo konkrečius sumanymus, kad minėtos kariuomenès dalys būtų tinkamai parengtos.

\section{II fazè}

Šios dalys, gavusios atskirą kariuomenès vado įsakymą, turèjo atvykti nustatytų grupių vadų žinion. Mobilizacijos skyriaus viršininkas taip pat buvo ipareigotas pateikti savo sumanymus dèl atskirojo bataliono Jonavoje suformavimo. Iki to laiko Jonavoje buvusią 1-ojo pèstininkų pulko kuopą, pradejjus formuoti batalioną, numatyta grąžinti i pulką.

Kaip jau minèta, kariuomenès vado lauko štabas buvo ikurtas Kaune, Marijampolès grupès - Marijampolèje, Alytaus grupès - Alytuje, Kaišiadorių grupès - Kaišiadoryse (komendantūros būstinèje), Ukmergès grupès - Ukmergèje. Priedangos grupių veikla buvo koordinuojama kariuomenès vado lauko štabo. Visi priedangos grupių pranešimai privalejjo būti siunčiami ir atitinkamų karo apygardų viršininkams.

Karo technikos viršininkas turejo pateikti savo sumanymus dèl kariuomenès tinklo išplètimo, pirmiausia - dèl Kaišiadorių su Alytumi tiesioginio sujungimo. Priedangos grupių reikalams tvarkyti buvo leista telefonus prijungti prie Pašto, telegrafo ir telefono valdybos linijų ${ }^{138}$.

Kariuomenès vadas gen. S. Žukauskas tą pačią lapkričio $30 \mathrm{~d}$. informavo krašto apsaugos ministrą plk. T. Daukantą, jog susidariusi bendra politine konjunktūra ir labai tikètina lenkų ginkluota agresija verčia jị itin susirūpinti, ar jam patikètos kariuomenès veiksmai galètų užtikrinti krašto laisvę. Jis pabrèžè, jog krašto kariuomenès galimas operacijų plotas yra glaudžiai susijęs su komunikacijų linija Žemaitijos link ir kad ši linija, suirus Slabados tiltui, būtų vienintelè su užnugariu siejanti „arterija“.

Gen. S. Žukauskas pabrèžè, kad tokia padètis gali būti vadinama tik katastrofiška. Dèl galimo konflikto jis paprašè krašto apsaugos ministro apie tokią būklę referuoti Lietuvos vyriausybei, pabrèžiant neatidèliotinos Kauno evakuacijos būtinumą. Jo teigimu, vyriausybei ši klausimą principingai išsprendus, būtų galima pateikti parengtą Kauno evakuacijos tvarkaraštį. Atsiųstoje operatyvinẻje direktyvoje krašto apsaugos ministras galejo matyti, jog yra numatyta nemažai didesnių dislokacijos pakeitimų, iš kurių du (ulonų eskadrono ir 1-osios lauko baterijos iš Vil${ }^{138}$ Ten pat, 1. 4-5. 
kaviškio perkèlimas ị Marijampolę) jau ịgyvendinami. Nuo kitų pertvarkymų teko susilaikyti, nes, nepaisant strateginių reikalavimų, dèl tarptautinès konjunktūros tuo metu to daryti dar nebuvo galima.

Gen. S. Žukauskas paprašè krašto apsaugos ministrą apie šių dislokacijos suvaržymų panaikinimą jị informuoti ${ }^{139}$.

Tuo metu iš 1927 m. gruodžio mèn. ị Lauko štabą atsiųstų daugybès raportų matyti, jog kariuomenès dalių vadai ir karinių ỉstaigų viršininkai, vykdydami kariuomenès vado direktyvą Nr. 21962, vietose atliko daug organizacinių ir kitų parengiamųjų darbų galimai lenkų agresijai atremti ${ }^{140}$.

Vidaus reikalu ministro nurodymu nuo $1927 \mathrm{~m}$. gruodžio $1 \mathrm{~d}$. pasienio policija prie demarkacijos linijos buvo sustiprinta 247 policininkais ir 10 rajonų viršininkų. Jie buvo paskirstyti Zarasų (48), Utenos (40), Ukmergès (27), Trakų (48), Alytaus (48) ir Seinų (48) apskričių centruose. Visi ginkluoti šautuvais ir 17 kulkosvaidžių ${ }^{141}$.

Kariuomenès vado įsakymu direktyva Nr. 21962 buvo papildyta. Iki to laiko veikęs karinis telefono tinklas buvo iš dalies praplèstas, nutiestos tiesioginès linijos: Kaunas-Alytus, Kaišiadorys-Alytus, Kaunas-Kaišiadorys ir Kaišiadorys-Jonava. Nuolatinių karinių telefono linijų priežiūra ir remontas buvo Ryšių bataliono pareiga. Su I karo apygarda buvo palaikomas radijo ryšys.

Nuo tos dienos (gruodžio 6-osios ) prie Marijampolès, Alytaus ir Ukmergès grupių štabų ryšiui palaikyti buvo priskirta ir po vieną motociklą ${ }^{142}$. Taip pat buvo issakyta neatidèliojant suregistruoti visus sunkiuosius ir lengvuosius automobilius šiuose punktuose ir jų artimiausiuose rajonuose: Marijampoleje, Vilkaviškyje, Alytuje, Kaišiadoryse ir Ukmergèje. Šių punktų karo komendantai privalèjo įvertinti transporto priemonių savininkų benzino ir tepalų atsargas, nurodyti sandèlius, kurie yra tinkami didesniam jų kiekiui laikyti. Registracijos dokumentuose turèjo būti nurodyta lengvųjų automobilių talpa ir sunkiụjų automobilių

\footnotetext{
${ }^{139}$ Kariuomenès vado gen. S. Žukausko 19271130 slaptas asmeninis raštas Nr. 21966 krašto apsaugos ministrui, ten pat, 1. 2.

${ }^{140}$ Dèl 19271130 kariuomenès vado direktyvos Nr. 21962 vykdymo, ten pat, 1. 27, 29, 31, $35-39,45-55,61-63,72-73,75-77,82-83$ ir t. t.

${ }^{141}$ VRM Piliečių apsaugos departamento direktoriaus A. Štaškevičiaus 19271203 visiškai slaptas raštas Lauko štabo viršininkui, ten pat, 1. 12.

${ }^{142}$ Kariuomenès vado gen. S. Žukausko 19271206 slaptas asmeninis įsakymas Nr. 22038, ten pat, 1. 15-16.
} 
tonažas. Automobilių registracija turèjo būti atlikta skubiai ir slaptai ${ }^{143}$.

Lietuvos ir Lenkijos santykiai toliau blogejo. Stiprèjo lenkų reakcinių politinių grupuočių kurstomos antilietuviškos nuotaikos. Po Tauragès pučo, pasinaudodami sunkia Lietuvos vidaus padètimi, lenkai aktyviai rengèsi kariniams veiksmams. Siekta panaudoti ir lietuvių politinius emigrantus - vadinamuosius plečkaitininkus. Lenkijos reakcionieriai buvo numatę žaibiškai užimti Kauną ir pasirašyti „taiką“" su naujai sudaryta Lietuvos vyriausybe. Pasirašiusi sutartị, Lietuva būtų turèjusi su Lenkija užmegzti ryšius, tarsi sudarytų uniją. Po to pagrindinès Lenkijos kariuomenès pajègos pasitrauktų iš Lietuvos, o "naująją tvarką“ saugoti būtų pavesta plečkaitininkų daliniams. Prireikus juos paremtų Lietuvoje paliktos nedidelès Lenkijos kariuomenès igulos ${ }^{144}$.

1927 m. gruodžio 5 d. Ženevoje prasidèjo Tautų Sąjungos Tarybos sesija. Po penkias dienas trukusių lietuvių ir lenkų atstovų kalbų gruodžio $10 \mathrm{~d}$. buvo priimta Tautų Sąungos Tarybos rezoliucija, skelbianti, kad: 1) karo tarp Lietuvos ir Lenkijos padètis panaikinta; 2) Lenkija pripažįsta Lietuvos politinę nepriklausomybę ir jos teritorijos integralumą; 3) rekomenduojama abiem šalims derybomis užmegzti normalius santykius ir t. t. ${ }^{145}$

Šios rezoliucijos viena svarbiausių rekomendacijų - pradèti Lietuvos ir Lenkijos derybas. Tačiau Lietuvos vyriausybè delsè tai daryti. Priežasčių buvo įvairių. Bene svarbiausia problema buvo Vilniaus klausimo atnaujinimas. Lietuva žiūrejo ị derybas kaip ì priemonę Vilniaus priklausomybès klausimui iškelti. Šalies visuomenè buvo ne kartą pabrèžusi, kad „pirmas svarbus mums reikalas yra įrašyti ị derybų programą Vilniaus klausimą " ${ }^{146}$. Žinant Lenkijos poziciją, derybos iš anksto buvo pasmerktos žlugti. Konfliktas su Lenkija tęsèsi.

Dèl tokios politinès konjunktūros lietuviai kiekvieną akimirką buvo priversti laukti agresyvių lenkų veiksmų. Lenkijos agresija galejo pasireikšti invazija i nepriklausomos Lietuvos teritoriją. Lietuvos politinei ir karinei vadovybei teko atsižvelgti i galimas priešo agresijos formas.

\footnotetext{
${ }^{143}$ Lauko štabo viršininko gen. št. plk. P. Kubiliūno 19270606 slaptas asmeninis nurodymas Mobilizacijos skyriaus viršininkui Nr. 22042, ten pat, 1. 21.

${ }^{144}$ LCVA, f. 383, ap. 7, b. 711, 1. 35.

${ }^{145}$ Priimtoji Tautų Sąungos Tarybos rezoliucija, Lietuva, 19271215.

${ }^{146}$ Derybų perspektyvos, Lietuvos žinios, 19280117.
} 


\section{Krašto apsaugos ministro gen. Itn. T. Daukanto $1928 \mathrm{~m}$. rugpjūčio 4 d. operatyvinè direktyva Nr. 22140}

Išanalizavus ir įvertinus susidariusią padètị, krašto apsaugos ministro ir Vyr. štabo Operacijų skyriaus nuomone, tikètina, kad lenkų agresijos prieš Lietuvą formos būtų ịvairios:

a) Karinès vadovybès paskatintų ìvairių nereguliariụjų dalių ịsiveržimas i Lietuvos teritoriją. Tokiu atveju parengiamojoje lenkų akcijoje galètų dalyvauti nedidelès reguliariosios pajègos, sustiprintos arba perrengtais civiliais, arba uniformuotais kariais. Gali būti, kad tokia akcija tęstųsi, kol šalies viduje kiltų didesnio ar mažesnio masto riaušès.

b) Nereguliariųjų pajėgų dalių akcija, kurią po tam tikro laiko paremtų reguliarioji Lenkijos kariuomenè.

c) Reguliariosios Lenkijos kariuomenès ịsiveržimas ị Lietuvos teritoriją. Tada šios pajègos netikètumo efektui užtikrinti pradètų ginkluotą akciją, Lenkijai karo viešai net nepaskelbus.

Lietuvos ginkluotųjų pajègų vadovybė numatė du pagrindinius kariuomenès veikimo būdus:

a) kariauti metodinị karą;

b) pritaikyti partizaninio, vadinamojo „mažojo karo“, sistemą.

Dèl šių dviejų pagrindinių variantų taikymo tinkamu laiku spręstų už krašto likimą atsakinga vyriausybè.

Tuo metu reikejo:

a) kiekvieną akimirką būti pasiruošusiems sustabdyti nereguliariųjų pajègų veržimąsi ị šalies teritoriją;

b) užtikrinti planingą paskelbtos mobilizacijos ir numatyto operatyvinio sutelkimo vykdymą nustatytu laiku.

Remiantis tuo metu galiojusiu mobilizacijos tvarkaraščiu Nr. 10, pirmosiomis dienomis mobilizuotas Lietuvos ginkluotąsias pajėgas turejjo sudaryti keturios pėstininkų divizijos, du kavalerijos pulkai ir daug kariuomenès vadovybès žinioje esančių dalių. Prie šių pajègų reikèjo dar numatyti:

1. tam tikrą skaičių dešiniajame Nemuno krante ịkurdintų šaulių rinktinių;

2. nemažai tuo metu dar besiformuojančių savarankiškų šaulių dalių, kurioms būtų tekę veikti ịvairiose Lietuvos teritorijos vietose ${ }^{147}$.

${ }^{147}$ Krašto apsaugos ministro gen. ltn. T. Daukanto 19280804 operatyvinè direktyva Nr. 22140, LCVA, f. 929, ap. 3, b. 611, 1. 22-23. 
Gausios lenkų III korpuso apygardos kariuomenès pajègos Lietuvos okupuotoje dalyje ir Lenkijos rytuose, periferijoje, tuo metu buvo dislokuotos šiose vietose:

a) I pėstininkų legionų divizija (1-asis, 5-asis ir 6-asis pèstininkų pulkai, 1-asis lengvosios artilerijos pulkas) - Švenčionyse ir Švenčionių rajone;

b) XIX pèstininkų divizija (77-asis, 66-asis ir 85 -asis pèstininkų pulkai, 19-ojo artilerijos pulko trys divizionai) - Vilniuje ir Pabradeje;

c) XIX péstininkų divizija (41-asis, 76-asis ir 81-asis péstininkų pulkai, 29-ojo lengvosios artilerijos pulko trys divizionai) - Gardine, Suvalkuose ir Marcinkonių rajone;

d) III atskiroji kavalerijos brigada (4-asis, 13-asis ir 23-iasis ulonų pulkai, 3-iosios raitosios kavalerijos divizionas) - Švenčionių rajone;

e) I kavalerijos divizija (keturi ulonų pulkai, 3-iasis raitųjų šaulių pulkas, trys raitosios artilerijos divizionai ir vienas šarvuotųjų automobilių eskadronas) - Baltstogès, Suvalkų ir Augustavo rajonuose;

f) 3-iasis sunkiosios artilerijos pulkas - Švenčionių rajone.

Be to, turèta žinių, kad Augustavo ir Seinų apylinkèse sugrupuota apie 3000 lenkų partizanų ir civiliškai perrengtų kareivių. Tuo metu visos III karo apygardos dalys buvo „ostrem pogotowie“. Visa 29-oji pėstininku divizija su pasienio apsaugos pulkais tomis dienomis išvyko iš Gardino Vilniaus kryptimi. Lenkijos karinè vadovybè oficialiai š̉ faktą aiškino kaip išvykimą i vasaros stovyklas ir rengimąsi rugsèjo $10 \mathrm{~d}$. vyksiantiems manevrams ${ }^{148}$. Tai buvo demagoginis komentaras. Jų oficialiojoje informacijoje nebuvo paminètos kai kurios kariuomenès dalys, pvz., 3-iasis pionierių pulkas, šarvuočių dalys, aviacija, ịvairios tarnybos ir t. t.

İvertinusi priešo pajègas ir tikslus, Lietuvos kariuomenès vadovybẻ numate šias veiksmų fazes:

I fazè - demarkacijos linijos stiprinimas ir pasirengimas vykdyti priedangos veiksmus;

II fazè - priedangos dalių išdèstymas;

III fazè - veikiančiosios kariuomenès pagrindinių pajègų telkimas jau mobilizacijai pasibaigus.

Visi šios direktyvos vykdytojai turẻjo būti viską iki smulkmenų

${ }^{148}$ Lenkų III karo apygardos dalių dislokacija 1928 m. rugpjūčio mėn., ten pat, 1. 102. 
numatę, organizaciniu požiūriu pasirengę, kad, gavę vadovybès įsakymą, galètų vykdyti fazių užduotis ${ }^{149}$.

Demarkacijos linijos stiprinimas ir pasirengimas vykdyti priedangos veiksmus

Šios fazès bendri uždaviniai:

a) užkirsti kelią galimiems smulkiems lenkų partizaniniams veiksmams prie Lietuvos demarkacijos linijos, o nepavykus to padaryti, imtis atitinkamų žygių ir vietoje juos likviduoti;

b) visiškai uždaryti abipusị judejjimą per demarkacijos liniją saugantis, kad šalies teritorijoje rengiamų mobilizacijos ir priedangos dalių veiksmų lenkų agentai ir šnipai neišsiaiškintų;

c) arčiausiai prie demarkacijos linijos esančioje zonoje budriai sekti priešo veiksmus;

d) atlikti reikalingus veiksmus rengiamiems priedangos barams sustiprinti ir jų budrumui padidinti.

Šios fazès punktuose nurodyti uždaviniai turèjo būti koordinuojami ir valdomi atitinkamų periferijos priedangos grupių vadų: Marijampolès grupè - 9-ojo pèst. pulko vado, Alytaus - 2-ojo ulonų pulko vado, Kaišiadorių - 5-ojo pèst. pulko vado, Ukmergès - 1-ojo pèst. pulko vado, Utenos-Zarasų - I karo apygardos viršininko.

Prasidejus šiai fazei, priedangos grupių visiškon operatyvinèn priklausomybėn pereitų pasienio apsaugos dalys ir visi atitinkamų barų šaulių būriai. Šią direktyvą gavę priedangos grupių vadai turèjo palaikyti glaudų ryši su atitinkamais vietos administracijos viršininkais (apskričių, pasienio apsaugos barų viršininkais ir šaulių būrių vadais) ir neatidèliodami parengti smulkų bendrą veiksmų planą. Visus tarp vietos administracijos organų kilusius nesusipratimus turejjo spręsti Vyr. štabas.

Buvo nustatyti priedangos grupių barai:

a) Marijampolès grupès baras: nuo sienos su Vokietija iki Galinių, Rudaminos, Krosnos punktų imtinai. Šis baras apėmė Vilkaviškio, Marijampolès apskritis ir dali Seinų apskrities.

b) Alytaus grupès baras: nuo Galinių, Rudaminos, Krosnos (išimtinai) iki Aukštadvario, Stakliškių (išimtinai), po administracinio padalinimo - Alytaus, Seinų apskritys ir dalis Trakų apskrities.

${ }^{149}$ Krašto apsaugos ministro gen. ltn. T. Daukanto 19280804 ruošiamoji operatyvinè direktyva Nr. 22140, ten pat, 1. 24. 
c) Kaišiadorių grupès baras: nuo Aukštadvario, Stakliškių imtinai iki kairiojo Neries upès kranto - Trakų apskritis.

d) Ukmergès grupès baras: nuo kairiojo Neries upès kranto iki Molètų, Labanoro, Kaltanėnų kelio išimtinai, Ukmergès apskritis ir dalis Utenos apskrities.

e) Utenos-Zarasų baras: nuo Molètų, Labanoro, Kaltanėnų kelio imtinai iki sienos su Latvija, Utenos ir Zarasų apskritys.

Numatytų veiksmų zona galejo taip pat apimti atitinkamą administraciniam Zarasų apskrities padalinimui skirtą Lietuvos ir Latvijos sienos dalị. Jie turejjo būti atlikti visiškai slaptai, o organizacinis darbas - preciziškai, kad, prireikus ar vos tik gavus karinès vadovybès nurodymą, viskas vyktų sklandžiai ir tai, kas suplanuota, būtų ịvykdyta.

Visi šios fazès sumanymai privalèjo būti atlikti mobilizacine tvarka, visiškai nekeičiant numatytų veiksmų, o galimi prieštaravimai sprendžiami užtikrinant sklandžią mobilizacijos eigą. I karo apygardos viršininkas šios fazès uždavinius būtų pavedęs ịvykdyti atitinkamam savo apygardos viršininkui.

Šios direktyvos adresatai, gerai susipažinę su aplinkybėmis vietoje, per trumpiausią laiką savo konkrečius sumanymus privalëjo pateikti krašto apsaugos ministrui, turèdami galvoje, kad:

- pirmiausia turi būti pasiruošę gerai darbą atlikti numatytų priedangos grupių štabai;

- itin svarbu - palaikyti nuolatinị ir patikimą telefono ryši su demarkacijos linijos padaliniais ir užtikrinti tolesni gautų žinių perdavimą;

- atitinkamų priedangų štabai turètų parengti demarkacijos linijos vietiniams ginkluotiems apsaugos būriams smulkią žinių apie priešą rinkimo instrukciją;

- šios fazès veiksmų pagrindas turi būti plati savarankiškos decentralizacijos ideja ${ }^{150}$.

Perejjusios demarkacijos liniją silpnesnès sudèties priešo gaujos iš karto turèjo būti vietoje likviduojamos. Stipresnèms priešo gaujoms spaudžiant, atitinkamų priedangų grupių vadai toliau ịsiveržusias gaujas privalèjo sulaikyti, išsiaiškinti svarbesnes jų veržimosi kryptis ir sudètį. Bet kokiu atveju žvalgyba nenutraukiama.

150 Ten pat, 1. 25-26. 
Pasienio apsaugos dalys, iš anksto sustiprintos šauliais, stipresnėms priešo pajègoms spaudžiant, turèjo trauktis tam tikromis ir iš anksto numatytomis kryptimis ị aiškiai nurodytus rajonus, kur jų veiksmai būtų toliau derinami su i pagalbą atvykusiomis dalimis. Priversti trauktis visi vietos pasienio apsaugos viršininkai, gresiant priešo invazijai, privalètų gelbèti pasienio zonoje esantị valdišką turtą.

Kad ir kokia forma vyktų pasienio apsaugos dalių susirèmimai su priešu, ypač svarbu, kad kautynių padariniai: sužeistieji, žuvusiųjų karių lavonai, amunicijos liekanos ir t. t. - liktų už demarkacijos linijos Lietuvos pusèje. Lietuvių pasienio apsaugos dalys bet kokiu atveju neturètų šios linijos peržengti ${ }^{151}$.

Demarkacijos linijos apsaugos barų veiksmams koordinuoti bùtų skiriami atitinkami priedangos pulkų vadai, sudaromi jų štabai. Štabų darbą organizuoti ir darbo metodus nustatyti turejjo būti pavesta atitinkamų karo apygardų viršininkams ir kavalerijos vadui.

Štabų dislokacijos vietos: Vyr. štabo - Kaune; Marijampolès grupès - Marijampolèje; Alytaus grupès - Alytuje; Kaišiadorių grupès - Kaišiadoryse; Ukmergès grupès - Ukmergèje; Utenos-Zarasų grupès - Utenoje.

Priedangos grupių veiklą tiesiogiai koordinuotų Vyr. štabas. Visi priedangos grupių pranešimai turèjo būti siunčiami ir atitinkamų karo apygardų viršininkams. Gavusios šią direktyvą priedangos dalys privalèjo būti pasiruošusios ne vèliau kaip per 6 val. išvykti operatyvinio pobūdžio uždavinių vykdyti.

Operatyvinès fazės uždaviniams vykdyti toliau išvardytos kariuomenès dalys, gavusios vykdomąji i̇sakymą, iš karto turèjo sudaryti šios sudèties priedangos grupes:

1. Marijampolès priedangos grupè: jau veikiantis grupès štabas, 9-ojo pést. pulko trys batalionai, 3-iojo artilerijos pulko viena baterija. Vienas pèstininkų būrys, ginkluotas dviem sunkiaisiais kulkosvaidžiais, turèjo būti parengtas užimti Kalvarijos punktą, 4-asis artilerijos pulkas pasiruošęs pasiųsti ị Marijampolę vieną lauko patrankų bateriją, 2 ulonų pulkas - vieną ulonų eskadroną.

2. Alytaus priedangos grupè: jau veikiantis grupés štabas, trys likę ulonų eskadronai. Du ulonų būriai, ginkluoti dviem lengvaisiais

${ }^{151}$ Ten pat. 
kulkosvaidžiais, turi pasirengti užimti Seirijų ir Daugų punktus.

3. Kaišiadoriu priedangos grupè: jau veikiantis grupès štabas, 5-ojo pest. pulko trys batalionai, 3-iojo artilerijos pulko viena lengvoji grupè ir vienas Karo mokyklos kavalerijos būrys. Numatyta užimti Mileigonių punktą pasiuntus vieną pestininkų būrị, ginkluotą dviem sunkiaisiais kulkosvaidžiais.

5-asis pèst. pulkas ir 3-iojo artilerijos pulko viena lengvoji grupe turèjo būti pasiruošę lipti ị vagonus nuo Šančių kariuomenei skirtos rampos, o vienas kavalerijos būrys žygio tvarka - vykti Žiežmarių link.

4. Ukmergès priedangos grupè: jau veikiantis grupès štabas, 1-ojo pèst. pulko trys batalionai, 2-ojo artilerijos pulko viena lengvoji grupe pusantros baterijos dydžio ir vienas husarų eskadronas.

Viesų ir Utenos punktus numatyta užimti vieno péstininkų būrio, ginkluoto 2 sunkiaisiais kulkosvaidžiais, jègomis.

2-asis artilerijos pulkas ir 1-asis husarų pulkas turèjo būti pasiruošę pasiųsti žygio tvarka į Ukmergę: pirmasis - vieną lengvąją grupę, susidedančią iš pusantros baterijos, antrasis - vieną husarų eskadroną.

Husarai ir ulonai privalejo pasirengti: pirmieji - išjoti ịsakyme nurodyta kryptimi, ulonai - vietoje vykdyti priedangos uždavinius.

Likusias Vilkaviškyje 4-ojo artilerijos pulko pajègas numatyta parengti vežti ị Kauną ${ }^{152}$.

Krašto apsaugos ministro gen. ltn. T. Daukanto ir l. e. Vyr. štabo viršininko pareigas gen. št. plk. P. Kubiliūno rengiamos operatyvinès direktyvos Nr. 22140 tekstas buvo išplèstas $1928 \mathrm{~m}$. rugpjūčio $8 \mathrm{~d}$. Jame plačiai apžvelgta priedangos dalių veiklos antroji fazé, kartu papildant ir patikslinant kai kuriuos jo teiginius.

Pirmiausia jame pabręžiama, kad, gavus trumpą issakymą, priedangos grupès turi būti suformuotos neatidèliojant ir išdèstytos vadovaujantis atskiru įsakymu, o visi be išimties kariuomenès dalių veiksmai, susiję su priedangos dalių sudarymu, atlikti visiškai slaptai ir, jei leidžia aplinkybès, nakties metu. Šis nurodymas galiojo ir priedangos dalims užimant priešakinius punktus. Priešo nereguliariosioms dalims įsiveržus i Lietuvos teritoriją, atitinkamų priedangos grupių vadai privalo imtis reikiamų priemonių, kad jos būtų likviduotos vietoje, ir kartu nepamiršti, jog priedangos grupès bet kuriuo metu turi būti pasiruošusios, ịsiveržus priešo

${ }^{152}$ Ten pat, 1. 27-29. 
reguliariajai kariuomenei, vykdyti mobilizacijos ir susitelkimo priedangą.

Priedangos grupių vadai turèjo skubiai šiam tikslui parengti ginkluotų šaulių ir pasienio policijos veiksmų planus.

Priedangos dalių uždaviniai:

1. Marijampolès grupé (9-ojo pèst. pulko trys batalionai, viena lauko baterija ir vienas ulonų eskadronas). Jos užduotis buvo užimti poziciją Liudvinavo-Vidgirių rajone, turint sustiprintą vieną sunkiųjų kulkosvaidžių būrị Kalvarijoje. Stipresnèms priešo pajègoms spaudžiant ir negalint išsilaikyti, metodiškai trauktis Kauno link, organizuojant gynybą tolesnèse eilinėse, iš anksto numatytose pozicijose, bet laikant svarbiausiąja atsitraukimo ašimi Suvalkų-Kauno plentą.

Ruože iki skiriamosios nuo Alytaus grupès linijos žinių rinkimą ị vakarus nuo Suvalkų-Kauno plento išplèsti ir skverbtis kuo giliau. Ypač stebèti Krosnos kryptị. Atsitraukimo Kauno link metu Marijampolès grupès vadas turètų visą laiką stebėti pelkètas Amalvos ir gretimas vietoves.

2. Alytaus grupè (trys ulonų pulko eskadronai ir viena artilerijos baterija). Užėmusi Daugus ir Seirijus vienu būriu, ginkluotu lengvuoju kulkosvaidžiu, Alytaus grupè susitelkia Alytuje ir laukia tolesnių nurodymų. Nedidelè pulko dalis (daugiausia - du būriai), parengus priedangą, siunčiama ỉ Jiezną, kur turètų sudaryti siunčiamų rytų kryptimi raitelių pajègų branduoli.

Alytaus grupė turès pasiruošti ginti teritoriją nuo Balbieriškio iki Žuvinto. Šiame rajone neatidèliojant turi būti atlikti rekognoskuotès darbai, kairiajame Nemuno krante iki skiriamosios nuo Marijampolès grupès linijos renkamos žinios. Taip pat būtina žvalgyti teritoriją Seirijų ir Simno kryptimi. Dešiniajame Nemuno krante svarbiausios buvo šios žvalgybos kryptys: Merkinė, Varèna, Valkininkai, Onuškis, Aukštadvaris, Semeliškès. Žvalgyba Onuškio, Aukštadvario, Semeliškių kryptimi turètų būti atliekama iš Jiezno.

3. Kaišiadorių grupe (5-ojo pèst. pulko trys batalionai, viena lengvoji artilerijos grupè, vienas kavalerijos būrys iš Karo mokyklos). Atrėmusi savo dešinijj sparną i Nemuną Strèvos upelio rajone, ji gynybos tvarka užimtų Bijautonių-Antakalnio ruožą, turẻdama, užèmusi Mijaugonių punktą, vieną pèstininkų būrị, sustiprintą sunkiaisiais kulkosvaidžiais.

Nurodyta, stipresnèms priešo pajėgoms spaudžiant ir negalint nurodytame ruože išsilaikyti, metodiškai trauktis Kauno link, organizuojant 
gynybą eilinèse numatytose pozicijose, kartu laikant savo dešinijj sparną atremtą $\mathfrak{i}$ Nemuno pakrantes. Kaišiadorių-Kauno geležinkelio linija taip pat turètų būti ginama.

Žinias nurodyta rinkti pradedant nuo Nemuno dešiniojo kranto ir $\mathfrak{i}$ šiaurę kuo arčiau Neries. Būtina žvalgyba itin svarbiomis kryptimis: Žiežmariai-Žasliai ir išilgai plento Kruonis-Jieznas. Dešinysis sparnas visą laiką turèjo būti atremtas ị Nemuno pakrantes, o kairiojo Nemuno kranto artimiausios prieigos - nuolat stebimos.

Kairysis sparnas būtų saugomas sunkiai pereinamo Pravieniškių miško. Kaišiadorių grupès vadas turejjo iš anksto organizuoti savo padalinio veiksmus numatytame ruože ir teikti krašto apsaugos ministrui konkrečius sparnų apsaugos sumanymus.

4. Jonavos kuopos užduotis buvo ginti Jonavos tiltus per Nerị, saugant artimiausias geležinkelio prieigas išilgai Neries ir Kauno link.

5. Ukmergès grupè (1-ojo pèst. pulko trys batalionai, viena lengvoji artilerijos grupe ir vienas husarų eskadronas). Jos pirmasis ginamas ruožas - Bagaslaviškis-Gelvonų rajonas, antrasis - išilgai Šventosios upès Veprių rajone iki Upninkų miestelio imtinai.

Ukmergès grupè, gavusi tam tikrą ịsakymą ir atsižvelgusi ị aplinkybes, turejjo užimti pirmąji ir antrąji ginamuosius ruožus. Priešo stipresnèms pajėgoms spaudžiant ir negalèdama nurodytuose ruožuose išsilaikyti, ji turèjo metodiškai trauktis Kèdainių link ir, neperžengusi Jonavos-Kèdainių vieškelio, organizuoti gynybą eilinèse numatytose pozicijose.

Žinios turèjo būti renkamos ruože nuo Neries upès ir toliau ị šiaurę iki Giedraičių-Želvos imtinai.

6. Husarų pulkas ( 3 eskadronai), sugrupuotas Kavarsko-Anykščių rajone ir pasiruošęs veikti kairiajame kariuomenès susitelkimo sparne arba Giedraičių kryptimi, turejjo tai daryti kartu su Ukmergès priedangos kairiuoju sparnu arba Utenos link, atitinkamai išplètus demarkacijos linijos žvalgybą. Visais atvejais svarbu palaikyti ryšį su Ukmergès priedangos grupe.

7. Šarvuotasis traukinys turejo būti parengtas bet kuriuo metu išvykti ir panaudotas kovos užduotims atlikti.

8. Žemutinio Nemuno grupè privalèjo išsidèstyti nustatyta tvarka ir būti pasiruošusi veikti.

9. Utenos-Zarasų baro pajègos turejjo toliau vykdyti demarkacijos 
linijos apsaugos uždavinius.

Išdèstę priedangos dalis, visi grupių vadai turèjo organizuoti žvalgybą kuo arčiau demarkacijos linijos, nuolat aiškintis priešo skverbimosi kryptis, jo pajègu organizavimo ypatumus, avangardo pasiektas ribas ir jo kavalerijos veiksmus ${ }^{153}$.

Priedangos grupių veiksmus privalèjo tiesiogiai koordinuoti Kariuomenès štabas. Išdèsčius priedangos dalis, visi operatyviniai pranešimai turèjo būti jam siunčiami.

Priedangos grupių išdėstymą privalèjo kontroliuoti šie priedangos štabai: Kariuomenès štabas - Kaune arba jo apylinkèse; Marijampolès priedangos štabas - Marijampoleje; Alytaus priedangos štabas - Alytuje; Kaišiadorių priedangos štabas - Rumšiškèse; Jonavos kuopos komandavimo punktas - Jonavoje; Ukmergès priedangos štabas - Gelvonyse arba Vepriuose, Utenos-Zarasų vietinis štabas - Utenoje.

Pirmąją fazę ịrengtas telefono tinklas turèjo būti praplèstas ir sutvarkytas remiantis atskiru issakymu.

Gavę minètą direktyvą, apygardų viršininkai turẻjo priedangos grupių vadams įsakyti pristatyti savo sumanymus, neatidèliojant, rekognoskavus nurodytas veikimo zonas ir tolesnes atsitraukimo pozicijas, per apygardu štabus pateikti savo konkrečius nurodymų papildymus, sumanymus ir priedangos dalių pradinio išdèstymo schemas ${ }^{154}$.

Tiekimas:

1. Sudarytos priedangos grupių dalys aprūpinamos tuo metu galiojančia tvarka.

2. Kariuomenès intendantas, priedangos grupèms pradejus veikti, iškart numato jų tolesnị aprūpinimą maistu ir pašaru, turẻdamas galvoje, kad šių atsargų pristatymas iš užnugario iš dalies turès vykti geležinkeliu.

Priedangos grupių vadai, susitarę su atitinkamais karo komendantais, iškart turès maistui ir pašarui gabenti sudaryti kolonas, kurios sugebètu pristatyti dalims reikalingą jų kiekį. Maisto ir pašaro kolonoms sudaryti priedangos dalių vadai galès panaudoti privačias pastotes ir automobilius. Be to, nuo šioje direktyvoje numatytų priedangos grupių faktinio sudarymo momento šios grupès turi būti finansiškai aprūpintos (turèti

${ }^{153}$ Krašto apsaugos ministro ir Vyr. štabo Operacijų skyriaus 19280805 slaptas asmeninis ruošiamosios direktyvos Nr. 22140 tęsinys, $L C V A$, f. 929, ap. 3, b. 611, 1. 45-47.

154 Ten pat, 1. 47-48. 
reikalingą pinigų sumą).

Artilerijos amunicija. Minimalų amunicijos kieki priedangos artilerijai aprūpinti rodo 1 lentelès duomenys.

1 lentelè $\dot{e}^{155}$

\section{Priedangos dalių aprūpinimas artilerija $1928 \mathrm{~m}$.}

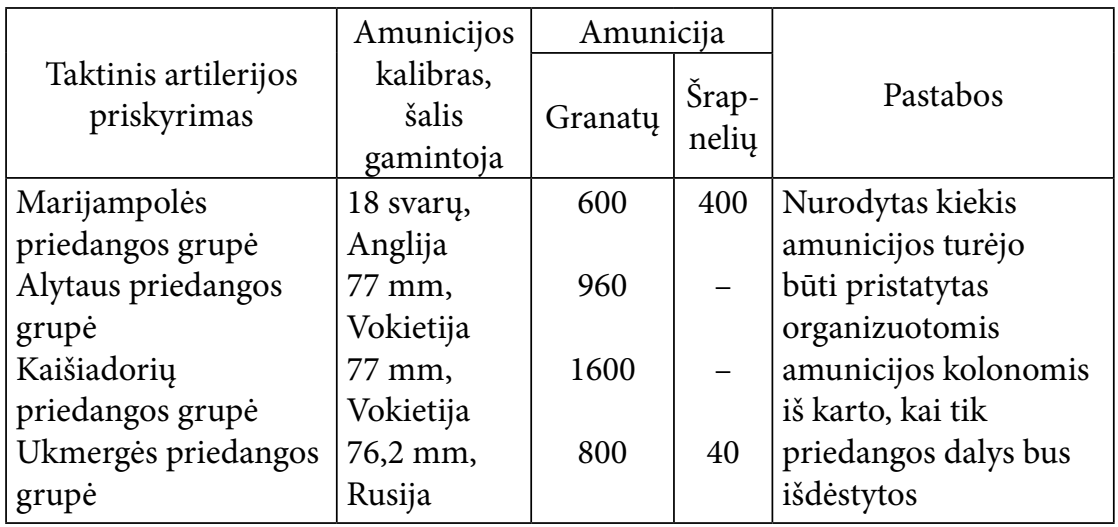

Tolesnis priedangos grupių aprūpinimas artilerijos amunicija turèjo būti atliekamas geležinkeliu - vežiojant kilnojamąji sandèlį, kurị nuo pat organizuojamų priedangos grupių faktinio sudarymo momento privalëjo aprūpinti artilerijos tiekimo viršininkas.

Atitinkama priedangos grupių amunicija iš artimiausio geležinkelio punkto turejjo būti gabenama ị vietas priedangos grupių jègomis. Vietinèms amunicijos kolonoms sudaryti priedangos grupių vadai, padedant atitinkamiems karo apygardų, artilerijos ir kavalerijos viršininkams, privalejo numatyti privačių automobilių ir pastočių paèmimo planus. Šios amunicijai transportuoti skirtos kolonos turejo būti sudaromos iš karto, kai tik išdèstomos priedangos dalys.

Artilerijos tiekimo viršininkas turèjo numatyti, kaip bus naudojamas Jonavos-Ukmergès siaurasis geležinkelis Ukmergès priedangos grupei amunicijai tiekti.

${ }^{155}$ Lentele sudaryta remiantis LCVA duomenimis, ten pat, 1. 49. 
Artilerijos geležinkelio kilnojamajame sandèlyje sudaroma šovinių ir rankinių granatų atsarga:

šautuvinių šovinių $\quad-3$ dienų norma;

kulkosvaidžių šovinių - 2 dienų norma;

rankinių granatų $\quad-1$ dienos norma ${ }^{156}$.

Evakuacija. Sužeistus ir sergančius karius numatyta evakuoti sanitariniais automobiliais tiesiai ị daktaro J. Basanavičiaus ligoninę ar artimiausią geležinkelio evakuacijos punktą, aprūpinamą priemonėmis sanitariniu vagonu.

Netransportuotini sužeistieji ir ligoniai turejjo būti evakuojami i artimiausias apskričių ligonines. Karo sanitarijos viršininkas privalèjo nurodyti, kaip reikia pritaikyti Jonavos-Ukmergès siaurojo geležinkelio vagonèlius sužeistiesiems ir ligoniams iš Ukmergès vežti.

Sanitarine evakuacijos grupé, sudaryta iš 4 sanitarinių automobilių ir 4 sanitarinių vagonų, turèjo būti parengta Kaune iš karto, kai tik priedangos dalys bus išdèstytos.

Arklių veterinarijos evakuacijos punktus buvo numatyta įrengti Marijampoleje, Alytuje, Rumšiškèse ir Ukmergèje ${ }^{157}$.

Kaip matyti, kariuomenès vadovybès $1928 \mathrm{~m}$. rugpjūčio 4 ir $8 \mathrm{~d}$. operatyviné direktyva Nr. 22140 to meto sąlygomis buvo itin išsami ir argumentuota. Joje buvo numatyti visi galimi negausių Lietuvos ginkluotųų pajègų veiklos būdai ir praktinès priemonès kraštui nuo agresyvaus kaimyno iš pietų apginti.

Ja vadovaudamasis atitinkamą direktyvą tų pačių metų rugpjūčio 10 d. parengè I karo apygardos štabas ${ }^{158}$, rugpjūčio 16 d. - II karo apygardos štabas ${ }^{159}$, rugpjūčio 29 d. - Marijampolès grupés štabas ${ }^{160}$, rugpjūčio

\footnotetext{
156 Ten pat.

${ }^{157}$ Ten pat, 1. 50. Ši direktyva pripažinta netekusia galios Vyr. kariuomenès štabo I skyriaus 19351129 raštu Nr. 10821, LCVA, f. 510, ap. 1, b. 139, 1. 5.

${ }^{158}$ I karo apygardos 19280810 slapta asmeninè ruošiamoji direktyva, LCVA, f. 929, ap. 3, b. $611,1.83-88$.

${ }^{159}$ II karo apygardos 19280816 slapta asmeninè priedangai nuo Lenkijos operatyvinè direktyva, ten pat, 1. 98-112.

${ }^{160}$ Marijampolès grupès štabo 19280829 slaptas asmeninis raportas Nr. 7 II karo apygardos viršininkui, ten pat, 1. 122-124.
} 
29 d. - Alytaus grupès štabas ${ }^{161}$.

\section{Vyriausiojo štabo $1928 \mathrm{~m}$. spalio $19 \mathrm{~d}$. direktyva Nemuno apsaugos rinktinei suformuoti}

Atsižvelgdamas ị lenkų nuolat keliamą grèsmę plačiam ir strategiškai svarbiam Lietuvos pietiniam ruožui, Vyr. štabas 1928 m. spalio 19 d. parengè slaptą asmeninę direktyvą Nemuno apsaugos rinktinei suformuoti (žr. 2 lentelę).

\section{Nemuno apsaugos rinktinės mobilizuojamų dalių sąrašas}

\begin{tabular}{|l|l|}
\hline \multicolumn{1}{|c|}{ Dalių pavadinimai } & \multicolumn{1}{|c|}{ Mobilizavimo vieta } \\
\hline $\begin{array}{l}\text { Nemuno apsaugos rinktinės štabas, Ryšių } \\
\text { komanda, Pionierių komanda, Ūkio } \\
\text { kuopa ir Raitųų žvalgų komanda }\end{array}$ & Raseiniai \\
\hline $\begin{array}{c}\text { I Nemuno apsaugos bataliono štabas } \\
\text { I bataliono } 1 \text { apsaugos kuopa }\end{array}$ & Čekišké, Kauno apskr. \\
I bataliono 2 apsaugos kuopa & Raudondvaris, Kauno apskr. \\
I bataliono 3 apsaugos kuopa & Vilkija, Kauno apskr. \\
I bataliono 4 apsaugos kuopa & Vilkijos dvaras, Vilkijos valsč. \\
I bataliono 5 apsaugos kuopa & Seredžius, Kauno apskr. \\
I bataliono 6 apsaugos kuopa & Čekiškè, Kauno apskr. \\
\hline II Nemuno apsaugos bataliono štabas & Armeniškių k., Seredžiaus valsč. \\
II bataliono 7 apsaugos kuopa & Vadžgirys, Raseinių apskr. \\
II bataliono 8 apsaugos kuopa & Veliuona, Kauno apskr. \\
II bataliono 9 apsaugos kuopa & Raudonè, Raseinių apskr. \\
II bataliono 10 apsaugos kuopa & Skirsnemunė, Raseinių apskr. \\
II bataliono 11 apsaugos kuopa & Jurbarkas, Raseinių apskr. \\
II bataliono 12 apsaugos kuopa & Stakiai, Raseinių apskr. \\
\hline
\end{tabular}

${ }^{161}$ Alytaus grupès štabo 19280829 veikimo ideja Nr. 19, ten pat, 1. 131-135.

${ }^{162}$ Lentele sudaryta remiantis Vyr. štabo 19281019 direktyva Nemuno apsaugos rinktinei suformuoti, ten pat, l. 189. 
Nemuno apsaugos rinktinę mobilizavo jos vadu paskirtas karininkas pagal prie šios direktyvos pridètus Nemuno apsaugos rinktinès karo meto etatus Nr. 40.

Nemuno apsaugos rinktinès viršininku buvo paskirtas plk. ltn. J. Čaplikas. Mobilizacini Nemuno apsaugos rinktinès karininkų skirstymą vykdè Vyr. štabas.

Nemuno apsaugos rinktinei suformuoti II ir III karo apygardų viršininkai privalejo skirti atitinkamą skaičių žmonių, arklių, vežimų ir pakinktų (žr. 3 lentelę).

3 lentelè $\dot{1}^{163}$

\section{Nemuno apsaugos rinktinès karo meto etatai Nr. 40 (santrauka)}

\begin{tabular}{|c|c|c|c|c|c|c|c|c|c|c|c|c|}
\hline \multirow[b]{2}{*}{$\begin{array}{c}\text { Tarnybos } \\
\text { pavadinimas }\end{array}$} & \multirow[b]{2}{*}{ 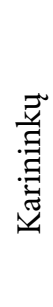 } & \multirow[b]{2}{*}{ 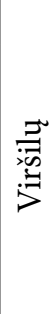 } & \multirow[b]{2}{*}{ 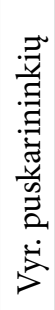 } & \multirow[b]{2}{*}{ 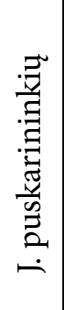 } & \multirow[b]{2}{*}{ 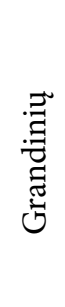 } & \multirow[b]{2}{*}{ 跒 } & \multirow[b]{2}{*}{ 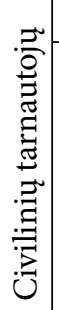 } & \multicolumn{2}{|c|}{ Arklių } & \multirow[b]{2}{*}{ 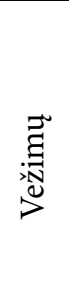 } & \multirow[b]{2}{*}{$\begin{array}{l}. \mathscr{Z} \\
\text { 苋 } \\
\text { 苛 }\end{array}$} & \multirow[b]{2}{*}{ 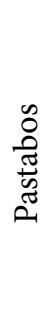 } \\
\hline & & & & & & & & 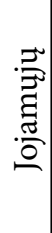 & 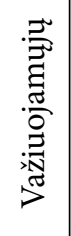 & & & \\
\hline Rinktinès vadas & 1 & - & - & - & - & 2 & - & 2 & 2 & 1 & plk. & \\
\hline Rinktinès štabas & 10 & 2 & 10 & 4 & - & 11 & - & 3 & 10 & 5 & & \\
\hline 2 batalionai & 66 & 12 & 68 & 296 & 378 & 2238 & - & 28 & 234 & 116 & & \\
\hline Ryšių komanda & 1 & 1 & 2 & 3 & 2 & 21 & - & 5 & 2 & 1 & & \\
\hline $\begin{array}{l}\text { Pionierių } \\
\text { komanda }\end{array}$ & 1 & 1 & 1 & 2 & 2 & 17 & - & 3 & 2 & 1 & & \\
\hline $\begin{array}{l}\text { Raitụjų žvalgų } \\
\text { komanda }\end{array}$ & 1 & - & 1 & 4 & 5 & 40 & - & 50 & - & - & & \\
\hline Ūkio kuopa & 1 & 1 & 5 & 9 & 1 & 87 & - & 2 & 72 & 34 & & \\
\hline $\begin{array}{l}\text { Iš viso } \\
\text { rinktinèje }\end{array}$ & 81 & 17 & 87 & 318 & 388 & 2416 & - & 95 & 322 & 158 & & \\
\hline & & & & 342 & & & & & 17 & & & \\
\hline
\end{tabular}

\footnotetext{
${ }^{163}$ Lentelè sudaryta remiantis Vyr. štabo viršininko gen. št. plk. P. Plechavičiaus 19281019 patvirtintais Nemuno apsaugos rinktinès karo metų etatais Nr. 40, ten pat, l. 195.
} 
Dalị atsarginių buvo numatyta palikti karo apygardose. Papildant lenteleje nurodytą atsarginių skaičių buvo numatyta jų priimti 25 proc. daugiau, negu reikejo poreikiams patenkinti, nes dèl registracijos netobulumo ir dèl to, kad, kai kuriems neatvykus, jų galejo pritrūkti. Susidarius žmonių pertekliui, Nemuno apsaugos rinktinès viršininkas galèjo likusius atsarginius perduoti II karo apygardos viršininkui.

Nemuno apsaugos rinktinè buvo mobilizuojama vadovaujantis bendromis M-1, M-2 ir M-3 instrukcijų taisyklèmis. Tačiau dèl jos mobilizavimo skubotumo ir savotiškų mobilizacijos sąlygų, be bendrų taisyklių, reikejo vadovautis dar ir šiais nurodymais:

a) žmones, arklius mobilizuoti, vežimus ir pakinktus rinkti Nemuno apsaugos rinktinei turejjo karo apygardų viršininkai ir po to juos perduoti Nemuno apsaugos rinktinès viršininkui. Bendrą mobilizacinị suskirstymą ir suskirstymą pagal apskritis ir valsčius turejjo atlikti Nemuno apsaugos rinktinès viršininkas ir iki tų pačių metų gruodžio $1 \mathrm{~d}$. pateikti karo apygardų štabams. Visi rinktinei papildyti mobilizuojami atsarginiai jau taikos metu turèjo būti paskirti ị atitinkamus štabus, batalionus ir kuopas ir prie mobilizacijos plano pridèti visų dalių asmeninès sudèties sąrašai. Todèl karo apygardų štabai, vadovaudamiesi Nemuno apsaugos rinktinès viršininko mobilizaciniu suskirstymu, privalejjo nurodyti apskričių komendantams atsarginius, surašyti juos pagal dalis ir šiuos sąrašus pateikti Nemuno apsaugos rinktinès viršininkui. Atsarginiai turèjo būti pašaukti itteikus šaukimo lapelius, apskričių komendantų pareiga buvo pasirūpinti jų gamyba ir užpildytus perduoti užantspauduotuose vokuose valsčių valdyboms saugoti;

b) mobilizaciją paskelbus, valsčių viršaičiai arba kaimų seniūnai turèjo surinkti Nemuno apsaugos rinktinès paskirtus atsarginius ir su jais vykti ị rinkimosi punktus. Tam reikalingų pastočių reikejjo ieškoti artimiausiose apylinkèse;

c) arkliai, vežimai ir pakinktai rinktinei taip pat renkami artimiausiose rinkimosi punktams apylinkèse.

Apskričių viršininkai taip pat turejjo sukomplektuoti reikalingą personalą mobilizacijai atlikti.

Nemuno apsaugos rinktine intendantūros, artilerijos ir technikos priemonių būtų gavusi iš atitinkamų tiekimo ịstaigų. Buvo numatyta iki 
gruodžio $1 \mathrm{~d}$. panaudoti garlaivius, automobilius ir pastotes ${ }^{164}$.

Tuo metu lenkų ịsiveržimo ị Lietuvos teritoriją grèsmè nuolat didejjo. Lenkijos valdžios šelpiama ir jų žvalgybos vadovaujama plečkaitininkų emigrantų organizacija ne tik kad tebeveikè, bet netgi tapo dar aktyvesnè.

\section{Vyr. štabo Operacijų skyriaus viršininko \\ gen. štabo plk. B. Jakučio $1929 \mathrm{~m}$. sausio $25 \mathrm{~d}$. raportas \\ Gen. štabo valdybos viršininkui}

Toliau komplikuojantis padéčiai Lietuvos pasienyje, Gen. štabo valdybos viršininkas Operacijų skyriaus viršininkui gen. št. plk. B. Jakučiui iškèlè uždavini pateikti savo samprotavimus dèl Lietuvos ginkluotųjų pajègų galimybès kilti ị žygi, jų mobilizacijos ir telkimo sistemos pakeitimo. Formuluojant ši uždavinị Operacijų skyriui nurodyta parengti bendrus mobilizacijos plano nuostatus, turint galvoje, jog ji turètų vykti 2 dienas, t. y. kad, šioms dviem dienoms praslinkus, Lietuvos ginkluotos, taktiniais vienetais mobilizuotos pajègos būtų visiškai parengtos pervežti ị sutelkimo vietas.

Operacijų skyriaus viršininko gen. št. plk. B. Jakučio teigimu:

1. Kalbant apie ginkluoto konflikto su lenkais galimybę, reikia atsižvelgti i pagrindinę jo ypatybę - i tai, kad, esant tokiai bendrai politinei konjunktūrai, lietuviams tektų šią agresiją atremti vieniems, be jokios sąjungininkų pagalbos, todèl karinè vadovybè pirmiausia orientuotųsi i vadovavimą gynybiniam karui. Šiuo atveju reikètų žinoti, kad lenkai puolamosios dispozicijos tvarka jau iš pat pradžių sugebès panaudoti ne mažiau ginkluotų vienetų nei lietuviai.

2. Lietuvos kariuomenès mobilizacijos paskelbimo momentas gali sutapti su lenkų susitelkimo užbaigimu. Neaišku tik, kokia forma šis priešo susitelkimas gali būti igyvendintas (pavyzdžiui, gal prisidengus kokiais nors manevrais ar kt.).

3. Lietuvių mobilizacijos planas apskritai negalejo būti izoliuotas todèl, kad, konflikto išvakarèse pašaukus ginkluotąsias pajėgas, lygiagrečiai būtų sprendžiama daugybẻ kitų svarbiausių klausimų, būtent:

- tikslinami operacijų planai;

${ }^{164}$ Vyr. štabo 19281019 slapta asmeninè direktyva Nr. 4737 Nemuno apsaugos rinktinei suformuoti, ten pat, 1. 189-191. 
- nustatoma strateginès priedangos organizacija ir jos kovinio potencialo galimybès;

- planuojamas pagal šią nuostatą bendras mobilizuotinos kariuomenès karių skaičius, nes šis klausimas turi būti glaudžiai siejamas su priedangos sistema;

- nustatoma kariuomenès organizacinè sistema tiek taikos, tiek karo metu;

- nustatoma karo prievolès sistema ir glaudžiai su ja susijęs mobilizacinis perẻjimo iš taikos ị karo metą koeficientas.

Nenagrinejjant visų šių punktų iš esmès, tenka konstatuoti, jog:

- galimo gynybinio karo operacijų planas ir visi galimi jo variantai jau buvo parengti;

- strateginès priedangos organizavimo trūkumai buvo gerai žinomi;

- kariuomenès organizacinès sistemos pakeitimo projektas Operaciju skyriaus buvo parengtas ir $1928 \mathrm{~m}$. birželio $14 \mathrm{~d}$. motyvuoto raporto forma pateiktas (brigadinè sistema);

- buvo rengiamas naujas karo prievolès įstatymas, todèl Operaciju skyriaus pastarosios darbo dienos ir buvo skirtos jam nagrinèti ${ }^{165}$.

Pažvelgus ị karo metų Lietuvos ginkluotųjų pajègų sudètị, pirmiausia krinta ị akis organizacinè ir kiekybinè dispozicija, kuri jau 10 metų egzistavo krašto gynybos sistemoje. Iš tikrųų Lietuvos taikos meto kariuomené (7 pèstininkų pulkai) aptariamuoju laikotarpiu negalèjo tvarkingai pereiti i karo meto padètí, nes ji visiškai neleido vykdyti strateginès priedangos operacijų (t. y. savarankiškai veikiant laimèti laiko ir teritorijos).

Sąvokos "taikos meto organizacija“, „mobilizacija“ ir „priedanga“ yra glaudžiai susijusios, todèl kiekviena iš jų negali būti atskirai nagrinèjama. Šios sąvokos netiesiogiai nurodo ir ketvirtą krašto gynybos elementą Lietuvos ginkluotųjų pajègų bendrą potencialą, pirmiausia - mobilizuojamų ar planuojamų mobilizuoti karių skaičių.

Tuo metu buvo žinoma, kad šalies mobilizuotą kariuomenę sudarys keturios péstininkų divizijos (pagal mobilizacijos tvarkaraščius), nors Lietuva, atrodo, buvo pajegti suformuoti jų ir daugiau. Dèl strateginès padèties lietuviai buvo priversti nustatyti minimalų veikiančiosios kariuomenès dydi - apsiriboti 6 divizijomis, tačiau šios normos buvo

${ }^{165}$ Vyr. štabo Operacijų skyriaus 19290125 slaptas asmeninis raportas Nr. 21116 Gen. štabo valdybos viršininkui, $L C V A$, f. 929, ap. 3, b. 654, 1. 5-7. 
būtina planingai siekti (P. S. Operacijų skyrius tuo metu negalejo remtis jokiu pažangesniu ginkluotųjų pajègų didinimo ir tvarkymo planu - V. L.).

Dèl priedangos. Buvo numatytos 3 būtinos kryptys: viena - Suvalkijos, dvi - Vilnijos link. Kiekvieną iš šiu krypčių turèjo dengti mažiausiai viena organizuota brigada, nes péstininkų pulkas, toks, koks tuo metu buvo - laikina išeitis, - tam netiko.

Išvada: Lietuvos tuomete taikos meto kariuomenè turëjo dvi pagrindines ydas:

- nebuvo pritaikyta strateginei priedangai atlikti;

- organizaciniu požiūriu buvo netobula, todèl negalëjo tinkamai atlikti mobilizacijos (7 pèstininkų pulkai galèjo išaugti tik ị 12 péstininkų pulkų).

Konkreti darbo ideja:

- mobilizacija turejo būti vykdoma vadovaujantis vienu pagrindiniu planu, tinkamu tiek gynybinio, tiek puolamojo karo atveju;

- mobilizacijos planas turèjo būti pritaikytas blogiausiai Lietuvos pajègų situacijai (kai priešas jau yra susitelkęs).

Lietuvos teritorijos suskirstymo idejja. Sienų konfigūracija ir apskaičiuotas laikas lèmé teritorijos a priori suskirstymą ị:

a) iprasta tvarka nemobilizuotinas zonas;

b) iprasta tvarka sunkiai mobilizuotinas zonas;

c) mobilizuotinas zonas.

Iprasta tvarka nemobilizuotina zona - 1-2 etapų nuotoliu nuo demarkacijos linijos esantis ruožas (strateginès priedangos priešakinis rajonas), kur mobilizacija ịprasta tvarka negalejo būti atlikta.

Iprasta tvarka sunkiai mobilizuotina zona - priedangos išdèstymo zona, taip pat Nemuno ir Šventosios rinktinių rajonas.

Mobilizuotina zona (per 2 dienas) - likusi teritorijos dalis.

Mobilizacijos vykdymas:

a) Ruožas A. Mobilizacija vykdoma vadovaujantis ypatingaisiais ịstatais nuo karo pavojaus padèties paskelbimo momento (šie ịstatai turejo iš karto pradèti galioti).

Pašauktieji sutelkiami $\mathfrak{i}$ nedidelius vienetus ir naudojami vietoje arba sienai uždaryti kartu su policija ir šauliais, arba atskiriems uždaviniams atlikti (pvz., Alytaus, Seinų apskrityse).

Klausimas, ar šiame ruože mobilizuotus žmones galima ịvardyti 
tarptautine sąvoka „reguliarioji kariuomenë“, tuo metu buvo paliktas atviras. Artimiausi priedangos dalims valsčiai galejo būti panaudoti mobilizacijos priedangos pajègoms papildyti.

b) Ruožas B. Mobilizacija vykdoma vadovaujantis ypatingaisiais istatais nuo pat karo pavojaus padèties paskelbimo. Mobilizuotieji teritorinès sistemos pagrindais nuvedami $\mathfrak{i}$ iš anksto paskirtas jų vienetams artimiausias zonas.

Šiame ruože karo pavojaus padèties paskelbimo ir strateginès priedangos išdèstymo laikas iš esmès sutampa.

c) Likusi teritorijos dalis. Kada bus paskelbta mobilizacija, priklausys nuo tinkamo priedangos parengimo (tiek organizaciniu, tiek kiekybiniu aspektu), tačiau bet kuriuo atveju tai negalès ịvykti vèliau negu priešas susitelks.

Priedangai organizuoti siūlyta mobilizuoti reikiamas pajègas ir jas dislokuoti numatytose vietose. Taikos meto organizacijoje numatyta priedangą vykdyti brigadomis (kiekviena - iš dviejų pėstininkų pulkų, iš kurių vienas - karo meto sudèties, sudarytas iš trijų batalionų, kitas - iš vieno bataliono; kavalerija turejo būti dislokuota sparnuose).

Mobilizacija: antras brigados pulkas ir kai kurios likusios brigados dalys turejo mobilizuotis karo pavojaus metu, likusios taikos meto dalys - iprasta brigados tvarka. Šiuo klausimu Operacijų skyrius buvo parengęs konkrečių sumanymų.

Vykdant mobilizaciją ir susitelkimą, Lietuvos rytinès ir pietinès periferijos, ìvykus ginkluotam konfliktui su lenkais, situacija būtų ypatinga, nes būtinai reikètų:

a) vyriausybès laiku priimto sprendimo uždaryti sieną;

b) vyriausybès tam tikruose periferijos ruožuose laiku paskelbtos ypatingosios padèties (karo pavojaus);

c) vyriausybės leidimo šalies strateginę priedangą sudarysiančius padalinius išvesti iš kareivinių ir išdèstyti numatytomis kryptimis;

d) vyriausybès leidimo paskelbti mobilizaciją.

Pabrežtina, kad minèti sumanymai turèjo būti vyriausybės iggyvendinami paeiliui ir nustatytu laiku. Tik tuomet karinė vadovybė savo ruožtu galètų a priori garantuoti planingą mobilizacijos ir susitelkimo vykdymą numatytu laiku. 
Puolamojo karo hipotezè: mobilizacija galejo būti atlikta planingai ir per iš anksto numatytą laiką - tokiu atveju, reikia manyti, iniciatyva būtų buvusi lietuvių rankose ${ }^{166}$.

Tuo metu Varšuvos vyriausybès kai kuriuose sluoksniuose labai gyvai svarstytas labai svarbiu laikomas Lietuvos klausimas. Manyta, jog būtu tikslinga paskelbti „Naująją Lietuvą“ su sostine Vilniumi. Šios Lietuvos valstybès vyriausybès priešakyje būtų pastatytas Lenkijai ištikimas J. Plečkaitis. Dèl to, autorių nuomone, tuometė nepriklausomos Lietuvos vyriausybė ir visa valstybė būtų patekusi ị labai sunkią padètị, tuo labiau kad „Naujoji Lietuva būtų kuo glaudžiausioje unijoje su Lenkija“167.

Remiantis žiniomis iš Varšuvos, „Naujosios Lietuvos“ vyriausybès Vilniuje sudarymo plano autoriai buvo gen. Edvardas Smiglas-Rydzas (Edward Śmigły-Rydz) ir J. Plečkaitis. Svarbiausi plano punktai buvo šie:

1. paskelbti Vilniaus kraštą ir miestą tikrąja „Lietuvos valstybe“ ir kad Kauno vyriausybė yra nuversta;

2. paskelbti Kauno vyriausybei karą;

3. šị karą laikyti dviejų Lietuvos dalių pilietiniu karu;

4. tolesnis žingsnis - kreiptis ị Tautų Sąjungą ir Lenkiją pagalbos - šis kreipimasis būtų "pateisinęs“ lenkų intervenciją ${ }^{168}$.

Diplomatiniuose sluoksniuose vèl imta kalbèti, kad, Tautų Sąjungai išnaudojus visas galimybes, Lenkija gali ryžtis užmaskuotai agresijai prieš Lietuvą. Tokio scenarijaus neatmetė ir paprastai gerai informuotas Lietuvos pasiuntinys Paryžiuje P. Klimas. 1929 m. liepos 26 d. ministrą pirmininką A. Voldemarą pasiekė P. Klimo perspejjimas, kad perversmo galima laukti jau rugpjūčio mėnesị. A. Voldemaro nurodymu P. Klimo rašto nuorašas buvo perduotas Lietuvos kariuomenès štabo viršininkui ${ }^{169}$.

Iš jo turinio matyti, jog perversmą numatyta įvykdyti jungtinèmis lenkų ir lietuvių (plečkaitininkų) pajègomis ir jau ieškoma j ministro pirmininko pareigas kandidato tarp lietuvių. Jam buvo keliami tam tikri

166 Ten pat, 1. 8-10.

${ }^{167}$ E. Generalinio štabo II skyriaus viršininko p. mjr. S. Raštikio 19290523 straipsnis slaptame biuletenyje Nr. 20, LCVA, f. 510, ap. 1, b. 163, 1. 63.

168 „Vilniaus Lietuvos“ sudarymo planas, e. Generalinio štabo II skyriaus viršininko p. mjr. S. Raštikio 19290619 slaptas pranešimas biuletenyje Nr. 23, ten pat, 1. 77-78.

${ }^{169}$ Nepaprastojo ir igaliotojo ministro P. Klimo 19290726 pranešimas A. Voldemarui, kurio nuorašas perduotas Kariuomenès štabo viršininkui, $L C V A$, f. 929, ap. 2, b. 998, 1. $83-86$. 
reikalavimai: užmegzti santykius su Lenkija, k kuriant pasiuntinybes Kaune ir Varšuvoje, vykdyti koordinuotą užsienio politiką ir derinti karinių pajègų veiksmus pavojaus atveju.

Lenkijos pagalba šiuo klausimu taip pat buvo numatyta: Vyr. štabas issipareigojo pasiųsti pajègas, sudarytas iš lietuvių emigrantų ir lenkų. Nors karių skaičius ir nebuvo nurodytas, teigta, jog jų bus tiek, kiek reikès. Šioje akcijoje lenkai spekuliavo, aiškindami, jog Lietuvoje, net pačiame Kaune, esą Lietuvos kariuomenès dalių, kurios „eis ị tą kombinaciją“. Lenkų ịsitikinimu, tuo metu Lietuvoje visuose opozicijos sluoksniuose buvo tiek desperacijos, kad ji „dètųsi net su velniu“. Be to, lenkai sakè turị daug šalininkų ir agentų tarp valdininkų ir karininkų, taip pat tiksliausių žinių, kas dedasi Kariuomenès štabe, Prezidentūroje ir Užsienio reikalų ministerijoje. Apie Lietuvos kariuomenès atsparumą lenkai net nekalbèjo, laikydami ją visiškai dezorganizuota ir niekam tikusia. Jie šiek tiek prisibijojo tik šaulių, bet, jų žiniomis, šie neturị nei pakankamai ginklų, nei tinkamos karinès organizacijos.

Pilsudskis labai jaudinosi dèl šios avantiūros sèkmingos eigos ir nenorejo mirti jos neįvykdęs. Jis manè, kad pasitaikè puikiausia proga: plečkaitininkų gaujos yra gerokai padidejusios - papildytos naujais pabègèliais ir lietuvių uniformomis perrengtais lenkų kareiviais, pajègios per 24 valandas užimti Kauną ir sudaryti naują valdžią, vadovaudamosi demokratinių laisvių atkūrimo ir santykių su Lenkija užmezgimo manifestu.

Pats Pilsudskis dažnai lankydavosi Vilniuje, žadejo net ten „atostogas praleisti“, idant būdamas arčiau galètų organizuoti visą konspiraciją. Kadangi plečkaitininkai, net kaip lietuvių opozicija, lenkams atrodè kiek odioziški, po perversmo jiems valstybès gyvenime nebūtų skiriamas svarbiausias vaidmuo. Už savo indèlị jie turèsią pasitenkinti tik gausia kompensacija. Pilsudskis gyrèsi, jog ir be jų turįs daug „savų“ žmonių net labai aukštose vyriausybès vietose... ${ }^{170}$

Tokiomis aplinkybėmis tuometė administracinès linijos apsauga neužtikrino net jai artimo ruožo mobilizacijos. Daug šiame ruože buvusių atsargos karių, arklių, vežimų, pakinktų ir kito piliečių rekvizuotino turto, karui kilus, galejo patekti i priešo rankas. Mobilizacijai šalies gilumoje atlikti reikejo laiko, o kad jo būtų laimèta, taikos meto sustiprintų kariuomenès dalių ir pasienio policijos nepakako.

170 Ten pat. 


\section{Krašto apsaugos ministro plk. ltn. J. Variakojo ir vidaus reikalų ministro P. Asavičiaus $1930 \mathrm{~m}$. gegužès $12 \mathrm{~d}$. instrukcija administracinei linijai uždaryti}

Gresiant karo pavojui, administracinei linijai uždaryti, mobilizacijos priedangai sustiprinti ir norédama apsaugoti nuo lenkų administracinès linijos ruože gyvenančius atsargos karius, gyventojų turètus arklius, vežimus, pakinktus ir kitą rekvizuotiną turtą, Krašto apsaugos ministerija pasitelkè Vidaus reikalų ministeriją, sutarusi su ja organizuoti administracinès linijos ruožo apsaugą. Tam tikslui turèjo būti kuriamos pasienio apsaugos dalys pagal taikos metu iš anksto parengtą planą, panaudojant tuometę pasienio policiją, kaip kadrus būsimoms pasienio apsaugos karo meto dalims sukurti.

Šiam tikslui Vidaus reikalų ministerija pažadèjo ateityje komplektuoti pasienio policijos žemesnijji personalą iš mobilizuojamų metų (ne vyresnių kaip 35-erių) atsargos rikiuotès puskarininkių, o aukštesnịji - iš atsargos rikiuotès karininkų. Pasienio policijos personalui kariškai lavinti krašto apsaugos ministras turèjo vidaus reikalų ministrui skirti reikiamą skaičių instruktorių ${ }^{171}$.

Pasienio apsaugos dalims kurti taikos metu parengtas administracinès linijos ruožas buvo suskirstytas organizaciniais-mobilizaciniais sektoriais. Kiekvienas sektorius apėmė keletą pasienio policijos rajonų, kurių tarnautojai, kilus karo pavojui, taptų tame sektoriuje formuojamų pasienio apsaugos dalių kadrais, taip pat tam tikrą teritoriją, kurią sudare keletas pasienio valsčių ir iš kurios tame sektoriuje karo pavojaus metu kuriamos pasienio apsaugos dalys turejjo būti papildytos atsarginiais kariais, gauti arklių, vežimų, pakinktų ir kito reikalingo turto (žr. 1 priedą ${ }^{172}$ ).

Sektorių viršininkus ir jų pagalbini personalą turejjo skirti Krašto apsaugos ministerija. Šie viršininkai taikos metu priklausė apskričių, i kurias jų sektoriai įejo, komendantams, o karo pavojaus metu - atitinkamų kariuomenès dalių vadams.

Sektorių viršininkų užduotis taikos metu buvo parengti planus karo pavojaus atveju pasienio apsaugos dalims sukurti ir administracinei linijai uždaryti, o karo veiksmams prasidejjus - priešo veržimuisi sulaikyti

${ }^{171} 19300512$ instrukcija administracinei linijai uždaryti, LCVA, f. 929, ap. 5, b. 212, 1. 28.

${ }^{172}$ Administracinès linijos ruožo suskirstymas, ten pat, 1. 144-145. 
arba stabdyti ir dar taikos metu atlikti visus parengiamuosius darbus. Sektorių viršininkų darbą reglamentavo kariuomenès Vyr. štabo leidžiamos direktyvos, instrukcijos ir įsakymai, jų reikalingas ištraukas kiekvienas sektoriaus viršininkas gaudavo iš atitinkamo apskrities komendanto arba kariuomenès priedangos vado.

Sektorių viršininkai turejjo atlikti visus jiems mobilizuoti pavestų dalių papildymo atsarginiais skaičiavimus, išskirstyti juos ị mobilizuojamas dalis ir jų dalinius, apskaičiuoti mobilizuoti numatytoms dalims reikalingą arklių, vežimų, pakinktų ir kitų reikmenų èminị, paskirstyti ji sektoriaus teritorijoje esantiems valsčiams, pavesti jų valdyboms šiuos reikmenis suregistruoti, aprašyti ir ịkainoti.

Karo pavojų skelbti galejo krašto apsaugos ministras per Vyriausiąji štabą, kuris pranešimą apie paskelbtą karo pavojų turèjo perduoti karo apygardų štabams ir pasienio apskričių viršininkams, o šie - sudaryti planą, panašų i mobilizacijos skelbimo planą, kuriame aiškiai ir tiksliai būtų nustatyta, kas ir kokiu būdu (telegrama, pasiuntęs pasiuntinius) skelbia karo pavojų. Gavusios žinią, valsčių valdybos privalèjo kuo skubiausiai išsiųsti atsarginiams šaukimo lapelius, o kaimų seniūnai - žiūrèti, kad visi juos gavę atsargos kariai rinktųsi ị nurodytas vietas, o suregistruotų reikmenų savininkai neatidèliodami pristatytų tuos reikmenis ten, kur sektoriaus viršininko nurodyta.

Pasienio apsaugos dalių mobilizacijai išbandyti arba tas dalis laikiniems karo pratimams atlikti galèjo surinkti, taikos metu paskelbęs bandomąji karo pavojų, krašto apsaugos ministras, susitaręs su vidaus reikalų ministru ${ }^{173}$.

173 Ten pat, 1. 33-34. 
1 priedas

\author{
S 1 a p t a 1. \\ 1 Priedas prie administracijos linija1 už- \\ daryti instrukcijos
}

ADHIMISTRACIJOS LINIJOS RUOŽO

S U S K I R S T Y M A S.

\begin{tabular}{|c|c|c|c|c|c|}
\hline \multirow{3}{*}{$\begin{array}{l}\text { Sektorių pavadinimas } \\
\text { ju vir } 1 \text { łininkų buve1nes }\end{array}$} & \multicolumn{4}{|c|}{ sektorius a pima } & \multirow{3}{*}{ Pastabos } \\
\hline & \multicolumn{2}{|c|}{$P$ a $s 1$ e $n 10$} & \multicolumn{2}{|c|}{$T \in r 1 t \circ r 1 \mathrm{~J} a$} & \\
\hline & Baro & Rajonus & $\begin{array}{c}\text { Apskxi } \\
\text { ties }\end{array}$ & Valsorius & \\
\hline $\begin{array}{l}\text { I. BARTININKU } \\
\text { (Bartniki) }\end{array}$ & $\begin{array}{l}\text { vilka- } \\
\text { virkid } \\
\text { Rezer }\end{array}$ & 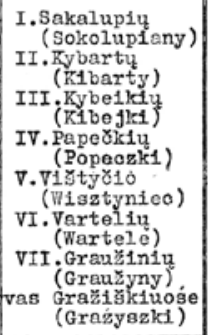 & 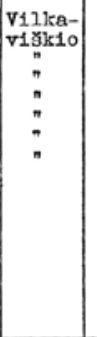 & 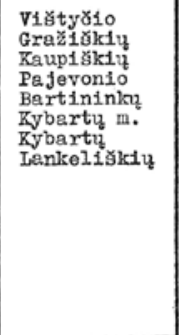 & \\
\hline II. RALVARIJOS & $\begin{array}{l}\text { Seinus } \\
\text { Mariam } \\
\text { polès }\end{array}$ & $\begin{array}{l}\text { I. Liubavo } \\
\text { (Lubowo) } \\
\text { II. Pcluomargio } \\
\text { (Polecmorg1) } \\
\text { III. Mockavos } \\
\text { (Hackowo) } \\
\text { IV. Buâviečio } \\
\text { (Budwiecie) }\end{array}$ & $\underset{n}{\operatorname{Sein}}$ & $\begin{array}{l}\text { Dudviec10 } \\
\text { Punsko } \\
\text { Rudarninos }\end{array}$ & \\
\hline 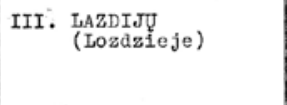 & & $\begin{array}{l}\text { V.Galinitu } \\
\text { (Galince) } \\
\text { VI. Aukštadvar1 } \\
\text { (Wyøoki Dv.) }\end{array}$ & $\mid \begin{array}{c}\text { Solnu } \\
" \\
n \\
\text { Alytgus }\end{array}$ & $\begin{array}{l}\text { Lazdiju } \\
\text { Kữianu } \\
\text { Sventezerio } \\
\text { Kateliu }\end{array}$ & \\
\hline IV. SEIRIJU & & $\begin{array}{l}\text { VII. Kauknor10 } \\
\text { (Kolenar) } \\
\text { VIII. Kapđ1am1eo } \\
\text { (Jio } \\
\text { (Kopciowo) } \\
\text { IX. Bugiedos } \\
\text { (Bugieda) } \\
\text { X. Gerdariu } \\
\text { (Gierdasze) }\end{array}$ & $\mid \begin{array}{c}\text { Selnu } \\
n \\
\text { Alytans }\end{array}$ & $\begin{array}{l}\text { Kapčiamiesðio } \\
\text { Lo1paling10 } \\
\text { Veiseju } \\
\text { Se1r1Ju }\end{array}$ & \\
\hline V. MERKIMES & Aly- & $\begin{array}{l}\text { I.If3ldavos } \\
\text { (Liszkowo) } \\
\text { II.Ucieios } \\
\text { (Ucleoha) } \\
\text { III.Mardasavo } \\
\text { (Uardosowo) }\end{array}$ & $\begin{array}{c}\text { Alytang } \\
n \\
n\end{array}$ & $\begin{array}{l}\text { Lijkiayos } \\
\text { Merldnés } \\
\text { Memunaiçıo } \\
\text { Alytaus m. }\end{array}$ & \\
\hline 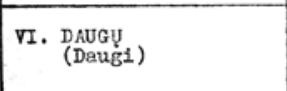 & & $\begin{array}{l}\text { IV. Perlojaus } \\
\text { (Pgzelaje) } \\
\text { V.Vórénos } \\
\text { (Orany) }\end{array}$ & $\begin{array}{c}\text { Alytaup } \\
n \\
n\end{array}$ & $\begin{array}{l}\text { Niedzingès } \\
\text { Varénos } \\
\text { Daugy } \\
\text { Alovés }\end{array}$ & \\
\hline
\end{tabular}


Lietuvos kariuomenès gynybos planai ir priemonès galimai lenkų agresijai atremti 1921-1937 m.

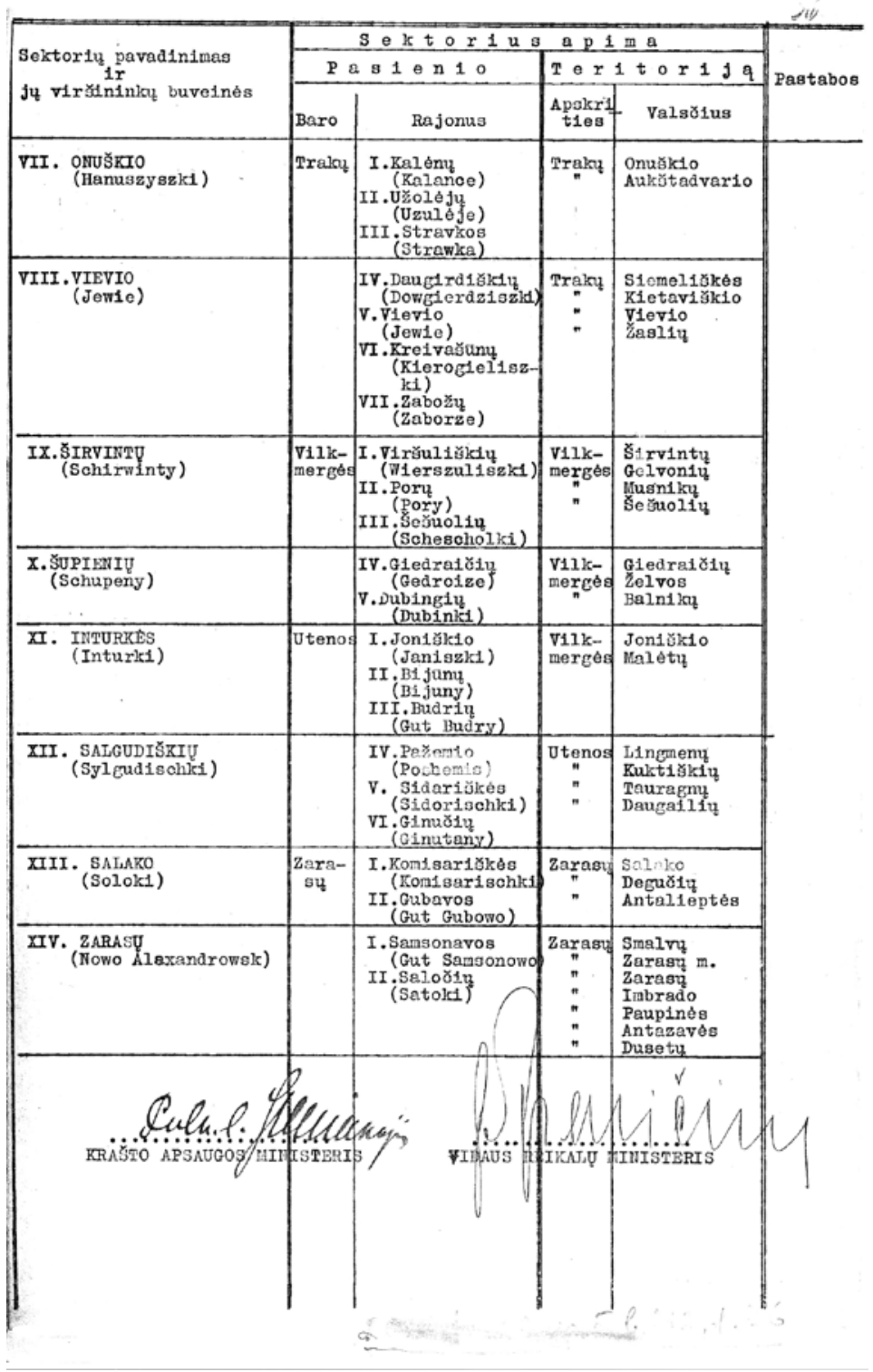


Nors 1929 m. rudenị ir įvyko vyriausybès asmeninès sudèties pokyčių, Lietuvos nuostatos dèl konflikto su Lenkija nepasikeitè. Naujasis užsienio reikalų ministras D. Zaunius tęsė A. Voldemaro politiką. Lietuvos delegacija, siunčiama ì Tautų Sąjungos $1930 \mathrm{~m}$. Asamblëją, buvo ịpareigota Lietuvos ir Lenkijos konflikto svarstymą panaudoti propagandai tarp Tautų Sąjungos narių. Lietuvos atstovai privalejo pasakyti Asamblèjoje ilgą politinę kalbą, kurioje būtų nušviesta Lietuvos ir Lenkijos konflikto genezè, politiniai, istoriniai ir ekonominiai Vilniaus klausimo aspektai ${ }^{174}$.

Tačiau pagrindiné Lenkijos ir Lietuvos konflikto dèl Vilniaus priklausomybės problema Tautų Sąjungoje nebuvo išspręsta ir vèlesniais metais. Ta proga žurnale „Mūsų Vilnius“ 1931 m. buvo rašoma: „Jei Tautų Sąjunga nori atstatyti normalius santykius, $<\ldots>$ ji privalo pradèti nuo pamato, iš kurio išdygo visos blogybès ir kurio nepataisius negalima nieko taisyti, būtent nuo Suvalkų sutarties ir Želigovskio smurto. O jei Sąunga šito negali padaryti, tegu tyli ir ị dalykus, kurių ji nepajègia, nesikiša. “175 Todèl Lietuva konflikto su Lenkija metu ketvirtajame dešimtmetyje pirmenybę teikè ne Tautų Sąjungos tarpininkavimui, o tiesioginèms deryboms. Lietuvos visuomenèje vyko plati diskusija dèl santykių su Lenkija perspektyvos.

O lenkai to dešimtmečio viduryje èmè smarkiai plètoti šmeižikišką kampaniją prieš Lietuvą, stengdamiesi kiekviena proga jai pakenkti. Kariuomenės vado gen. št. plk. S. Raštikio $1935 \mathrm{~m}$. sausio $12 \mathrm{~d}$. aplinkraštyje karininkams teigiama, kad to meto lenkų vadovaujančių sluoksnių mègstamas darbo metodas buvo sèti nepasitikèjimą tarp pačių lietuvių. Kad savo tikslą pasiektų, jie ėmèsi visų įmanomų priemonių ir negailèjo tam lèšų. Jie šmeižtu kiršino savo tautą prieš Lietuvą ir tokiu pat būdu siekè, kad kitos valstybès būtų neigiamai nusistačiusios Lietuvos atžvilgiu, stengèsi vaizduoti Lietuvos karininkus intriguojančiais politikieriais, mėgino papirkti spaudą, skleidè nepasitikèjimo ir nepasitenkinimo sèklas tarp lietuvių, bandè didinti ekonominị spaudimą ${ }^{176}$.

${ }^{174} 19300626$ Memorandumas. Lietuvos-Lenkijos konfliktas Tautų Sąjungos Taryboje, LCVA, f. 383, ap. 7, b. 1164, 1. 284.

175 Žepkaitè R., Diplomatija imperializmo tarnyboje..., p. 224-250.

${ }^{176}$ Kariuomenès vado gen. št. plk. S. Raštikio 19350112 slaptas aplinkraštis Nr. 5, LCVA, f. 929 , ap. 9 , b. $75,1.174$. 
Aštrejjant Lietuvos ir Lenkijos santykiams ir didejjant ịtampai Europoje, kariuomenès vadovybei pasiūlius, $1935 \mathrm{~m}$. buvo patvirtinti nauji karo meto etatai ${ }^{177}$.

\section{Kariuomenès vado gen. št. plk. S. Raštikio 1936 m. sausio $14 \mathrm{~d}$. direktyva pasienio apsaugos dalims mobilizuoti Nr. 4297}

Keičiantis politinei paděčiai ir didejjant lenkų agresijos pavojui, kariuomenès vadas gen. št. plk. S. Raštikis su Kariuomenès štabo viršininku gen. št. plk. J. Černiumi, remdamiesi mobilizacijos tvarkaraščiu Nr. 4, parengè naują slaptą direktyvą pasienio apsaugos dalims mobilizuoti. Pasienio apsaugos dalių kūrimo tikslas buvo, kilus pavojui, uždaryti valstybės sienas ir administracinę liniją ir jas aktyviai ginti.

Pasienio apsaugos dalis mobilizuojant atskirai, be mobilizacijos tvarkaraščių Nr. 11 ir Nr. 12, kai kariuomenès mobilizacija dar neskelbiama, bet jau kyla karo pavojus, joms mobilizuoti ir buvo skirtas mobilizacijos tvarkaraštis Nr. 4. Visais atvejais pasienio apsaugos dalys turèjo būti kuriamos tik teritoriniu principu, pirmiausia naudojant pasienio ir administracinès linijos policiją ir pasienio ruože esančius šaulių būrius, surenkant iš artimiausių vietų reikalingus arklius, vežimus ir pakinktus. Karininkai ir kareiviai pagal mobilizacijos tvarkaraštị turẻjo būti šaukiami išsiuntus šaukimo lapelius, o arkliai, vežimai ir pakinktai pristatomi pagal paraginimus.

Karininkų ir kareivių šaukimo, taip pat arkliams, vežimams ir pakinktams surinkti skirti paraginimo lapeliai turejo būti raudonos spalvos, o pati mobilizacija vykdoma gavus iš Kariuomenès štabo III skyriaus krašto apsaugos ministro ir kariuomenès vado pasirašytą tokio turinio įsakymą arba telegramą: „RESPUBLIKOS PREZIDENTO İSAKYMU SKELBIAMA PASIENIO APSAUGOS DALIŲ MOBILIZACIJA.“

Skelbiant mobilizaciją pagal mobilizacijos tvarkaraštị Nr. $4 \$ 8$, numatytą ịsakymą arba telegramą iš Kariuomenès štabo III skyriaus turejjo gauti:

a) visi divizijų vadai;

${ }^{177}$ Respublikos Prezidento A. Smetonos ir ministro pirmininko J. Tūbelio 1935 m. patvirtinti Krašto apsaugos ministerijos karo meto etatai, LCVA, f. 929, ap. 5, b. 433, 1. 1-3. 
b) tiekimo, ginklavimo, karo technikos, intendantūros, sanitarijos, veterinarijos, priešlèktuvinès apsaugos, Šaulių sąjungos ir kariuomenės I, II ir IV skyrių viršininkai, kavalerijos ir karo aviacijos viršininkai.

Divizijų vadai turèjo paskelbti apskričių komendantams ir viršininkams, kurių apskrityse pagal mobilizacijos tvarkaraštị Nr. 4 kuriamos apsaugos dalys, tai turèjo sužinoti ir pèstininkų pulkų vadai.

Jei mobilizacija pagal mobilizacijos tvarkaraštị Nr. 4 dar nebūtų paskelbta, o skelbiama mobilizacija pagal mobilizacijos tvarkaraščius Nr. 11 ir Nr. 12, mobilizacijos tvarkaraštis Nr. 4 turètų būti automatiškai vykdomas kartu su mobilizacijos tvarkaraščiais Nr. 11 ir Nr. 12 visoje valstybès teritorijoje.

Pasienio apsaugos dalių batalionų vadais būtų paskirti apskričių komendantūrų karininkai, kuriems iki tol buvo pavesta tvarkyti šaulių reikalus, o jų pritrūkus - vyresnieji atsargos karininkai, tarnavę pasienio policijoje. İ dalių, mobilizuojamų pagal mobilizacijos tvarkaraštị Nr. 4, kuopų vadų ir žemesnes pareigas turẻjo būti skiriami visų kuopų atsargos karininkai, gyvenantys ar tarnaujantys pasienio ar administracinès linijos zonose, tam taip pat buvo galima panaudoti ir visus pasienio policijoje tarnavusius atsargos karininkus. Pasienio apsaugos dalis turejo sudaryti pasienio ir administracinès linijos policija ir šaulių būriai.

Pasienio apsaugos dalių mobilizacijos greitis turéjo didžiausią reikšmę. Todèl reikèjo stengtis, kad pasienio apsaugos dalių mobilizacija būtų atlikta kuo greičiau. Buvo pageidaujama, kad pasirengimas žygiui užtruktų ne ilgiau kaip 10 valandų nuo įsakymo gavimo.

Kiekvienais metais iki birželio ir gruodžio $1 \mathrm{~d}$. turèjo būti peržiūrimi ir tobulinami pasienio apsaugos dalių mobilizacijos planai, o prireikus koreguojami. Jie turèjo parodyti pasienio apsaugos dalių tikrajj vaizdą ir pasirengimą žygiams ${ }^{178}$.

Krašto apsaugos ministras plk. inž. S. Dirmantas $1936 \mathrm{~m}$. kovo 26 d. patvirtino Atskirojo pasienio apsaugos bataliono karo meto etatus Nr. 119. Jais remiantis, batalioną sudarè: štabas (24 žmonès), dvi

${ }^{178}$ Kariuomenès vado gen. št. plk. S. Raštikio ir Kariuomenès štabo viršininko gen. št. plk. J. Černiaus 19360114 slapta asmeninè direktyva Nr. 4297 pasienio apsaugos dalims mobilizuoti, LCVA, f. 3, ap. 1, b. 267, 1. 14-22. Toliau žr. 4 lentelę (sudarytą remiantis kariuomenès vado gen. št. plk. S. Raštikio ir Kariuomenès štabo viršininko gen. št. plk. J. Černiaus duomenimis), LCVA, f. 3, ap. 1, b. 267, 1. 24-25. 
apsaugos kuopos (kiekvienoje po 244 žmones), raitųjųžvalgų dviratininkų būrys (39 žmonès), ryšių inžinerijos būrys (42 žmonès) ir ūkio būrys (26 žmonès). Visame pasienio apsaugos batalione turèjo būti 619 žmonių.

Batalionas turejo 389 šautuvus, 112 karabinų, 4 sunkiuosius kulkosvaidžius, 18 lengvųjų kulkosvaidžių, 80 pistoletų, 22 kardus, 619 šalmų, 28 raketines, 617 dujokaukių, 53 žiūronus, 41 kompasą ir kt. ${ }^{179}$

${ }^{179}$ Krašto apsaugos ministro plk. inž. S. Dirmanto 19360626 patvirtinti slapti Atskirojo pasienio bataliono karo meto etatai Nr. 119, LCVA, f. 1, ap. 1, b. 430, 1. 22-25. 
LIETUVOS RESPUBLIKOS KARIUOMENĖ (1918-1940 M.)

$\frac{\stackrel{0}{*}}{\stackrel{4}{*}}$

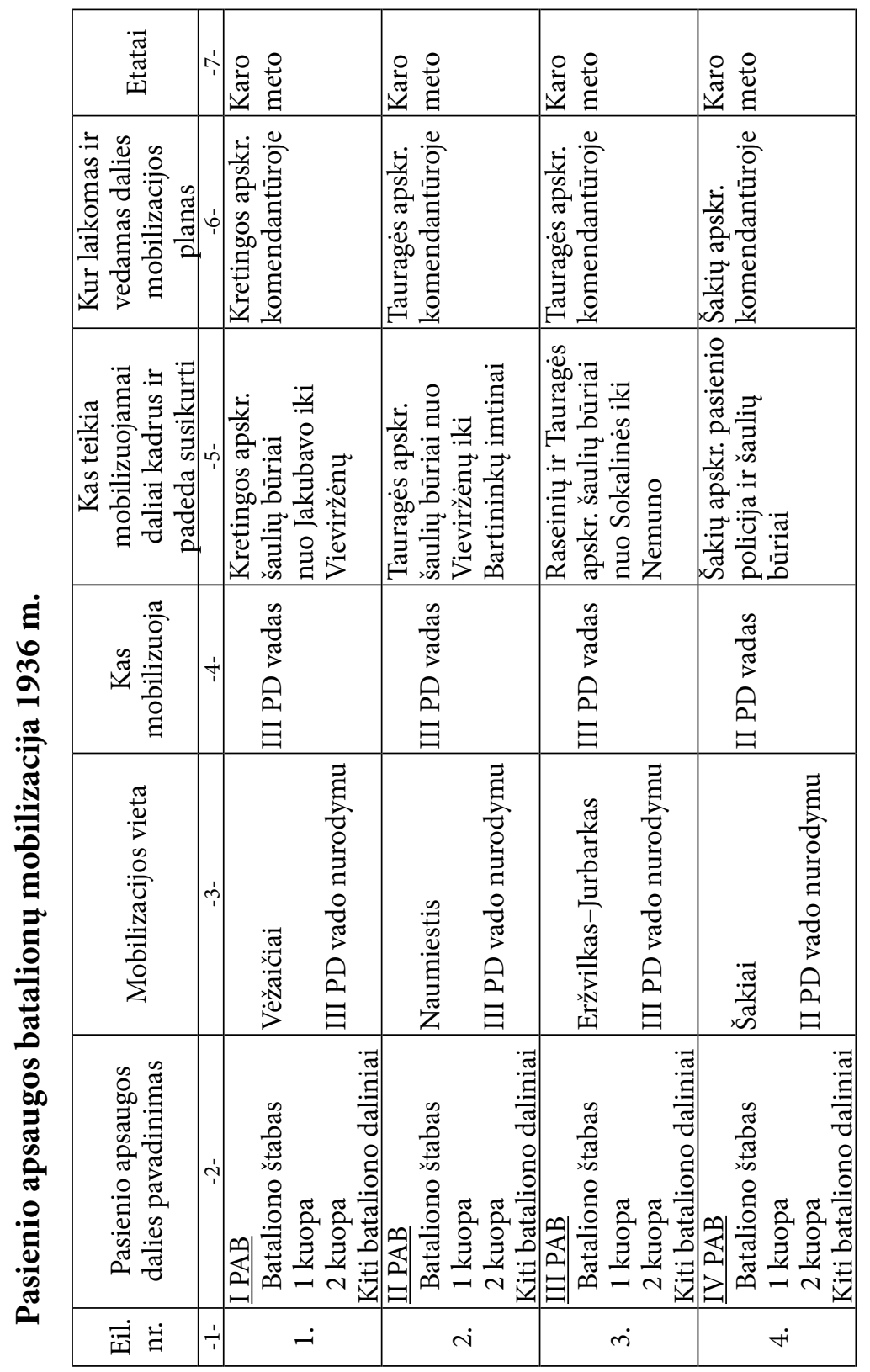


Lietuvos kariuomenès gynybos planai ir priemonès galimai lenkų agresijai atremti 1921-1937 m.

\begin{tabular}{|c|c|c|c|c|}
\hline & 惫 & 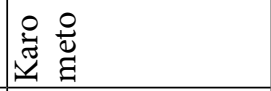 & 웝 & 율 \\
\hline & 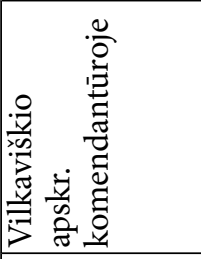 & 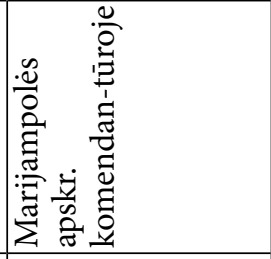 & 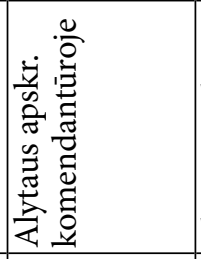 & 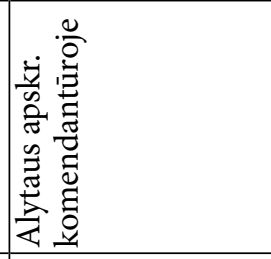 \\
\hline & 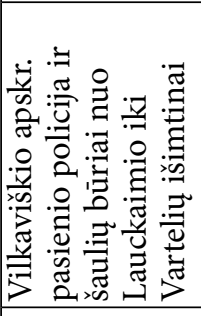 & 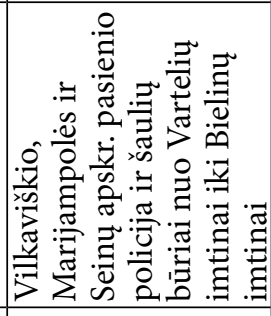 & 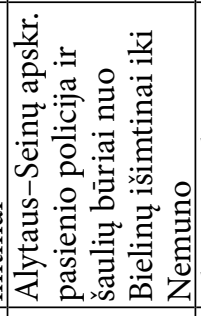 & 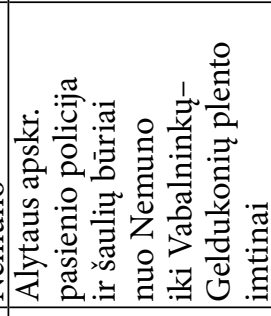 \\
\hline † & 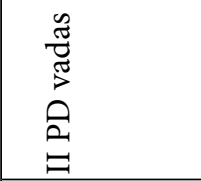 & 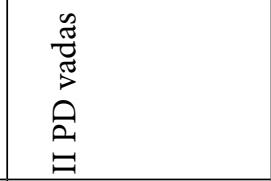 & 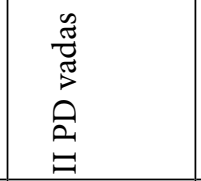 & 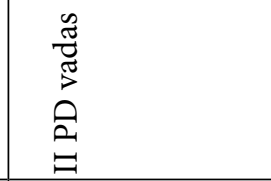 \\
\hline r. & 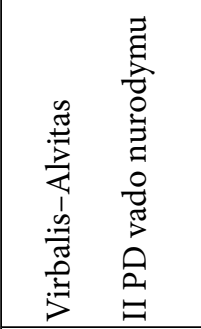 & 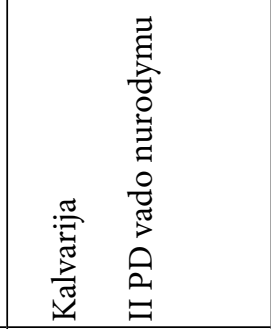 & 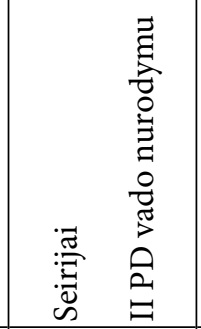 & 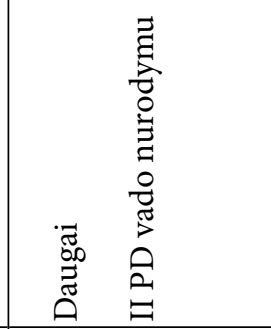 \\
\hline ণ่ & 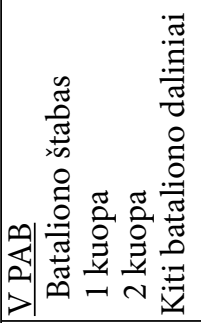 & 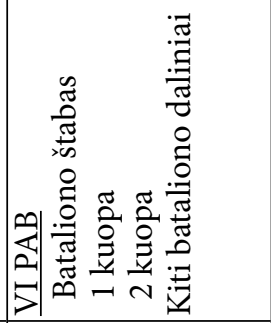 & 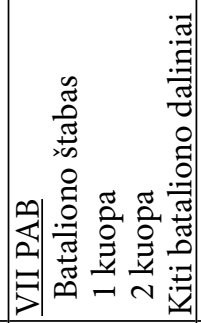 & 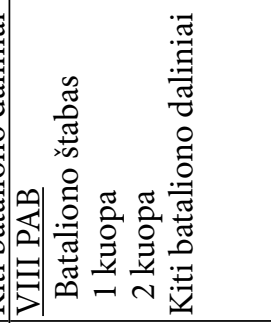 \\
\hline 1 & $\dot{10}$ & $\dot{0}^{\circ}$ & $\Lambda^{\circ}$ & $\infty$ \\
\hline
\end{tabular}




\begin{tabular}{|c|c|c|c|c|c|c|}
\hline \multicolumn{2}{|c|}{ 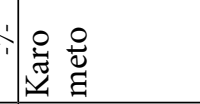 } & 율 & \multicolumn{2}{|l|}{ 惫 站 } & \multicolumn{2}{|l|}{ 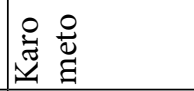 } \\
\hline & 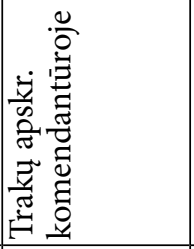 & 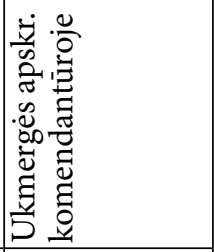 & 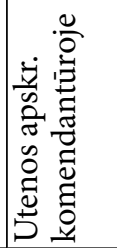 & & 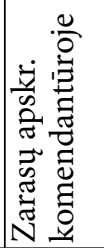 & \\
\hline & 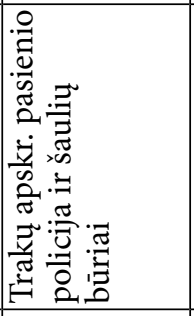 & 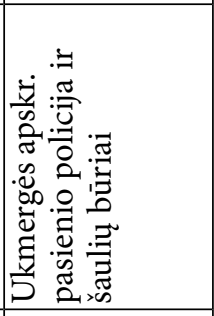 & 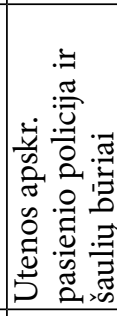 & & 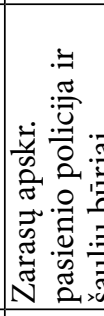 & \\
\hline+1 & 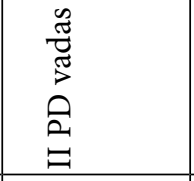 & 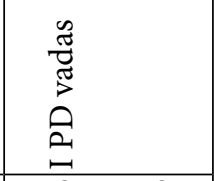 & 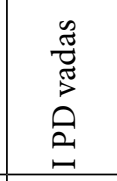 & & 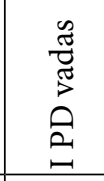 & \\
\hline$\stackrel{\leftrightarrow}{\longrightarrow}$ & 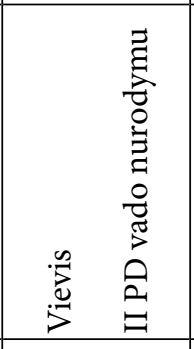 & 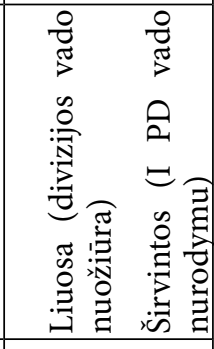 & 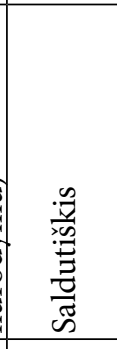 & 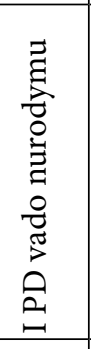 & $\begin{array}{l}\frac{\tilde{J}}{\tilde{n}} \\
\frac{\pi}{\tilde{J}} \\
\tilde{n}\end{array}$ & 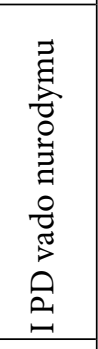 \\
\hline$\stackrel{\sim}{\sim}$ & 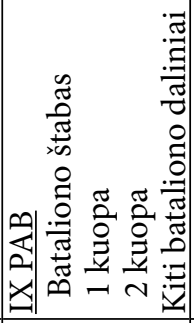 & 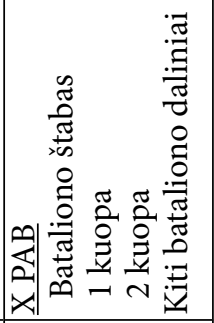 & 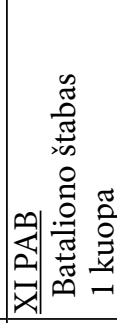 & 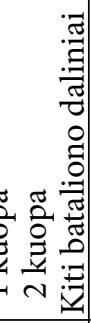 & 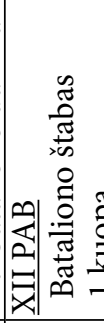 & 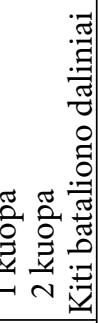 \\
\hline $\begin{array}{c}-1 \\
-1\end{array}$ & 5 & $\dot{0}$ & $\exists$ & (1) & & $\dot{v}$ \\
\hline
\end{tabular}

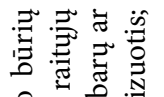

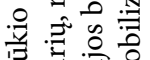
의

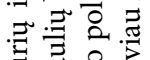

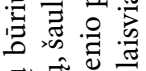

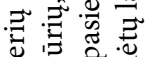

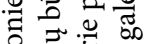

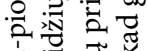
记 整客宫 象

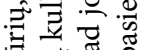

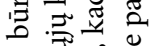

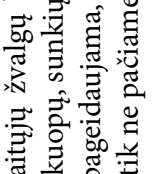
픈

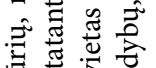

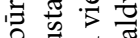
录芯范焉

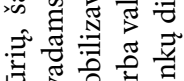

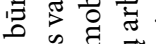

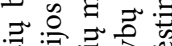

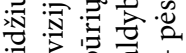
昰密

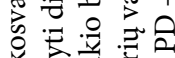

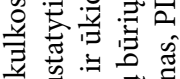
约

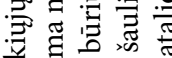
氙急污 क

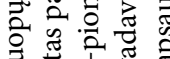
卷

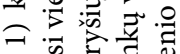
ت己

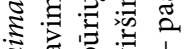
곤

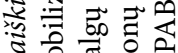
ฉ 


\section{Krašto apsaugos ministro plk. inž. S. Dirmanto ir vidaus reikalų ministro J. Čapliko $1936 \mathrm{~m}$. kovo $27 \mathrm{~d}$. administracinei linijai ir valstybès sienai uždaryti instrukcija Nr. 4993}

Atsižvelgdamas ị sparčiai besikeičiančią situaciją ir didejjančią ịtampą valstybès pasienyje, krašto apsaugos ministras plk. inž. S. Dirmantas ir vidaus reikalų ministras J. Čaplikas $1936 \mathrm{~m}$. kovo $27 \mathrm{~d}$. paskelbẻ naują slaptą instrukciją administracinei linijai ir valstybės sienai uždaryti. Joje, be minètų kai kurių pakartotinių nurodymų, buvo iškelta ir daug naujų reikalavimų.

Instrukcijoje buvo pabrèžta, kad pasienio apsaugos, be tiesioginių pareigų, tikslas - organizuoti greitą sienos uždarymą ir aktyvų saugojimą. Šiuos uždavinius taikos metu privalèjo atlikti pasienio policija, kuri paskelbus karo pavojų ir mobilizaciją, turejo įeiti ị mobilizuojamų pasienio apsaugos dalių sudetit.

Pasienio apsaugos dalis sudarè:

a) pasienio policija;

b) pasienio ruože esantis valstybinių ịstaigų ir žinybų personalas - atsargos karininkai, puskarininkiai (mokytojai, eiguliai ir kt.);

c) kiti pasienio ruože esantys atsargos karininkai ir kareiviai;

d) karinès vadovybès paskirti aktyviosios tarnybos karininkai ir kareiviai.

Pasienio policijos valdininkai buvo renkami iš atsargos rikiuotès karininkų, ne jaunesnių kaip 21 ir ne vyresnių kaip 45 metų, pasienio policininkai - iš 21-26 metų atsargos rikiuotès puskarininkių, išskyrus Latvijos pasienio policininkus, kurie galejo būti ir iki 28 metų, atsargos eiliniai kareiviai, jei jie buvo kūrèjai savanoriai arba turèjo bent vidurinès mokyklos mokslo cenzą, arba buvo apmokyti kariuomeneje, mokomojoje kuopoje.

Pasienio policijos personalą skyrė Vidaus reikalų ministerija. Apie pasienio policijos valdininkų, pradedant rajonų viršininkais, skyrimą ir perkèlimą iš vieno baro ị kitą Vidaus reikalų ministerija iš anksto turejjo pranešti kariuomenès štabo viršininkui, o šis dèl to galejjo reikšti savo pageidavimus.

Pasienio policijos ginkluotè turejo būti suderinta su karo meto pasienio 
apsaugos dalių ginkluote, t. y. pasienio policija buvo aprūpinta ginklais, kurie tiktų ir pasienio apsaugos dalims. Pasienio policijos dislokaciją nustatydavo vidaus reikalų ministras. Apie tai buvo pranešama Kariuomenès štabo viršininkui. Dèl pasienio policijos rajonų viršininkų būstinių ir rezervų (mokomụjų būrių) vietų Kariuomenès štabas galèjo reikšti savo pageidavimus. Kariuomenès štabui paprašius, Vidaus reikalų ministerija turejjo teikti jam pasienio policijos asmeninès ir turto sudèties žinias.

Pasienio policija taikos metu priklausè Vidaus reikalų ministerijai, tik rengiant operatyvinius ir mobilizacijos planus - divizijų vadams. Karo metu visa pasienio policija arba jos dalys, nuo mobilizacijos paskelbimo dienos ịtrauktos ị karinių pajègų sudètị, priklausẻ kariuomenès vadovybei.

Pasienio ruože $(20-30 \mathrm{~km})$ atitinkamų divizijų vadų nurodymu, iš anksto susitarus su apskričių viršininkais, 1-2 kartus per metus turejo būti organizuojami trumpalaikiai karo pratimai, juose privalèjo dalyvauti kuo daugiau pasienio policijos tarnautojų ir šaulių.

Visuose Vidaus reikalu ministerijos pasienio policijos tarnautojams rengiamuose kursuose kariniams dalykams buvo skirta pakankamai laiko. Šių dalykų programas ir valandų skaičių nustatydavo ministerija ir Kariuomenès štabas, o mokomųjų dalykų lektorius siūlydavo skirti kariuomenès vadas.

Ši instrukcija ịsigaliojo nuo 1936 m. balandžio 1 d., o 1930 m. instrukcija administracinei linijai uždaryti nuo tos dienos neteko galios ${ }^{180}$.

Dar nuo 1935 m. rugpjūčio 16 d. galiojo direktyva Nr. 5698 kariuomenès mobilizacijai parengti ir vykdyti. Kariuomenès mobilizacijos planą sudare tvarkaraščiai Nr. 11 ir Nr. 12. Vadovaujantis tvarkaraščiu Nr. 11 mobilizacija turejo būti vykdoma iškart visoje valstybès teritorijoje, o mobilizuotos kariuomenès dalys ir ịstaigos performuotos pagal karo meto etatus. Pagal tvarkaraštị Nr. 12 mobilizacija vyktų arba vienu metu visoje valstybės teritorijoje, arba kurios nors divizijos plote.

Mobilizacijos tvarkaraščiai Nr. 11 ir Nr. 12 turèjo būti taip suderinti, kad, paskelbus mobilizaciją pagal tvarkaraštị Nr. 12, automatiškai galètų kartu vykti ir mobilizacija pagal tvarkaraštị Nr. $11^{181}$.

${ }^{180} 19360327$ administracinei linijai ir valstybinei sienai uždaryti instrukcija Nr. 4993, LCVA, f. 929, ap. 3, b. 848, 1. 128.

${ }^{181}$ Kariuomenès vado gen. št. plk. S. Raštikio 19350816 slapta direktyva Nr. 5698 kariuomenès mobilizacijai parengti ir vykdyti, ten pat, 1. 5-24. 
Vykdant išleistas direktyvas pastebèta, kad mobilizacijos planai iki nurodyto termino nebūdavo parengti daugiausia dèl to, kad viršininkai vieni kitiems laiku nepateikdavo šiems planams sudaryti reikalingų žinių ir nurodymų. Atsižvelgdamas ị tai kariuomenès vadas ịsakè:

1. Ginklų rūšių ir tarnybų viršininkams savo papildomoms ir kuriamoms dalims ir ịstaigoms reikalingų žmonių, arklių, vežimų, pakinktų ir susisiekimo technikos priemonių reikalavimus atitinkamiems pèstininkų diviziju štabams pateikti per 12 dienų nuo direktyvos gavimo dienos.

2. Divizijų štabai, atlikę bendrą mobilizacinį suskirstymą, ginklų rūšių, tarnybų viršininkams ir 3-iojo pesst. pulko vadui žinias apie papildomą žmonių ir kitų išteklių skyrimą (bendro mobilizacinio suskirstymo ištraukas) siųsti tuo pat metu, kai jos siunčiamos apskričių komendantams.

Be to, kariuomenès vadas atkreipe dèmesị $\mathfrak{i}$ tai, kad papildomų ir keičiamų kariuomenès dalių ir ịstaigų sąrašai ir karo meto etatai yra ypač slapti mobilizacijos dokumentai. Šiuos dokumentus, kaip sudarančius svarbią tarnybinę paslaptị, turètų matyti kuo mažiau mobilizacijos direktyvos vykdytojų, kitaip sakant, galima rodyti tik tiems karininkams, kuriems jie būtinai reikalingi rengiant mobilizacijos planus.

Visi mobilizacijos dokumentai (direktyvos mobilizacijos planams rengti, mobilizacijos planai, karo meto etatai, tabeliai ir t. t.), kurių svarba buvo tuo didesne, kuo aukštesnè įstaiga buvo juos išleidusi, turèjo būti saugomi griežtai laikantis M-3 instrukcijos nurodymų ${ }^{182}$.

Kariuomenès mobilizacijos sèkmè, be kita ko, priklausè ir nuo mobilizuotų atsarginių punktualumo. Todèl reikejjo, kad kiekvienas atsarginis gerai suprastų to svarbą ir žinotų, kad, mobilizaciją paskelbus, pavèlavimas atvykti $\mathfrak{i}$ nurodytą kariuomenès dalị gali turèti lemiamą reikšmę valstybès gynybai.

Turint tai galvoje, divizijų vadai ir tarnybų viršininkai buvo prašomi duoti nurodymus pavaldiems dalių vadams, kad, kiekvieną kartą išleidžiant $\mathfrak{i}$ atsargą arba iš pratybų („karo pratimų") kareivius, be Taisyklių kareiviams $₫ 61$ p. (1926 m. krašto apsaugos ministro įsakymas Nr. 89) reikalavimų, jiems būtų tinkamai išaiškinta, kaip svarbu mobilizacijos metu atsarginiams laiku atvykti $\mathfrak{i}$ kariuomenę. Ta pačia proga

${ }^{182}$ Kariuomenès štabo viršininko gen. št. plk. J. Černiaus 19350816 raštas Nr. 5725, $L C V A$, f. 1364 , ap. 1, b. $396,1.86$. 
jiems turejo būti pasakyta, kad toks vèlavimas - didelis nusikaltimas ir už ji gresia sunki bausmè (žr. Karinès prievolès ịstatymo 205 str.).

Apskričių komendantai šį svarbų dalyką atsarginiams turèjo išaiškinti ataskaitinių tikrinimų metu ${ }^{183}$.

Poreikis skelbti kariuomenès mobilizaciją galëjo kilti staiga, visai nelauktai ir tokiu paros metu, pavyzdžiui, vakare, kai to padaryti dar tą pačią dieną, t. y. iki 24 valandos, jau nebeįmanoma. Tokiu atveju, kad ir koks svarbus būtų reikalas, mobilizacija galejo prasidèti ir beveik visa para vèliau, nes tektų laukti kitos dienos 00 val. 01 minutès.

Siekiant sumažinti tokios spragos žalą, reikejjo, kad ne tik pasienio apsaugos, bet ir priedangos dalių pasirengimas mobilizacijai galètų prasidèti bet kokiu paros metu, nelaukiant sutartos mobilizacijos pradžios 00 val. 01 min. Kitaip sakant, mobilizacija pagal mobilizacijos tvarkaraščius Nr. 4 ir Nr. 11 prasidètų tuoj pat gavus ịsakymą.

Kad tai būtų igyvendinta, kariuomenès vadas ịsakè:

1. Kariuomenès dalims, tarnyboms ir įstaigoms, mobilizuojamoms pagal tvarkarašti Nr. 11, žygiui pasirengti: pestijos, kavalerijos ir artilerijos dalims, išskyrus 6-ąji pèst. pulką, - per 24 valandas, 6-ajam pèst. pulkui ir visoms kitoms dalims ir ịstaigoms - per 30 val. gavus mobilizacijos ìsakymą.

2. Be nurodyto direktyvoje mobilizacijos paskelbimo įsakymo ar telegramos teksto, mobilizaciją pagal mobilizacijos tvarkaraštị Nr. 11 vykdyti gavus krašto apsaugos ministro ir kariuomenès vado pasirašytą telegramą ar ịsakymą: „Isakau tuojau pradèti vykdyti tvarkaraštị vienuoliktą numeri. ${ }^{\text {"184 }}$

Gavus tokio turinio telegramą, mobilizacija turejo būti vykdoma nelaukiant, kol ji bus viešai paskelbta.

Sutvarkius pasienio apsaugos daliu planus ir pertvarkius priedangos dalių mobilizaciją, kariuomenés vadas atsisaké pagal mobilizacijos tvarkaraštị Nr. 12 ją vykdyti atskiromis divizijomis. Jeigu, jau paskelbus pasienio ir priedangos dalių mobilizaciją, dar būtų reikèję skelbti mobilizaciją ir pagal tvarkaraštị Nr. 12, būtų neužtekę mobilizuoti vienos kitos

${ }^{183}$ Kariuomenès štabo viršininko gen. št. plk. J. Černiaus 19360907 slaptas aplinkraštis Nr. 5502, LCVA, f. 929, ap. 5, b. 460, 1. 122.

${ }^{184}$ Kariuomenès štabo viršininko gen. št. plk. J. Černiaus 19361030 slaptas asmeninis raštas Nr. 5693, LCVA, f. 929, ap. 9, b. 134, 1. 151. 
divizijos, o tekę skelbti mobilizaciją visame valstybès plote. Taip samprotaudamas ir turèdamas galvoje, kad parengiamieji atskirų divizijų mobilizacijos darbai buvo painūs, kariuomenès vadas mobilizacijos direktyvą pakeite:

1. Mobilizacijos tvarkaraštis Nr. 12 vykdomas visame valstybès plote - atsižvelgiant $\mathfrak{i}$ tai buvo atitinkamai pataisyti ir kiti paragrafai, kur kalbama apie atskirų divizijų mobilizavimą.

2. Direktyvos $\$ 9$ buvo pakeistas taip, kad atskiroms divizijoms mobilizuoti šaukimo lapelių spalvos nebeturèjo reikšmès. Tik mobilizacijos pagal tvarkaraščius Nr. 4 ir Nr. 11 šaukimai liko raudoni. Siekiant išvengti didelio lapelių perrašymo darbo, tol, kol bus sunaudotos jų atsargos, nutarta geltonos, žalios ir baltos spalvos lapelius laikyti lygiareikšmiais. Mèlyni lapeliai buvo palikti aviacijai ir priešlèktuvinei apsaugai, tačiau, šios spalvos lapelių atsargoms pasibaigus, nurodyta pereiti prie bendros priedangos dalims skirtos spalvos - raudonos. Taigi ateityje turèjo būti naudojamos dvi spalvos: vykdant mobilizaciją pagal tvarkaraščius Nr. 4 ir Nr. 11 - raudona, pagal Nr. 12 - balta ${ }^{185}$.

\section{Aukštaičių rinktinès bandomoji mobilizacija 1937 m. spalio 21-23 d.}

Aptariamojo laikotarpio pabaigoje, be mobilizacijos planų rengimo ir jų tobulinimo, kariuomenès vadovybè dažniau èmé organizuoti ir pačias mobilizacijas. Viena iš tokių buvo $1937 \mathrm{~m}$. spalio 21-23 d. įvykdyta vadinamoji Aukštaičių rinktinès bandomoji mobilizacija Utenoje, kur buvo kuriamas tik vienas péstininkų batalionas. I ją buvo įtraukti 8 valsčiai ir Utenos miestas. Mobilizacija truko 84 val. Kitaip tariant, nuo mobilizacijos paskelbimo iki dalinio pasiruošimo vykdyti uždavini praejjo 3,5 paros. Tai neabejotinai buvo per ilgas laiko tarpas. Lietuvos sąlygomis vargu ar galima buvo tiek ilgai mobilizuotis ${ }^{186}$.

Kad mobilizacijos laikas sutrumpètų, tiek ją rengiant, tiek vykdant buvo atlikta nemažai esminių pakeitimų. Daugelis dalykų, teoriškai samprotaujant, atrodè darniai ir sklandžiai ịvykdomi, bet praktiškai galèjo

${ }^{185}$ Kariuomenès štabo viršininko gen. št. plk. J. Černiaus 19370210 slaptas asmeninis raštas Nr. 33263, LCVA, f. 929, ap. 3, b. 848, 1. 139.

${ }^{186}$ Aukštaičių rinktinės bandomosios mobilizacijos 193710 21-23 reliacija, LCVA, f. 929, ap. 5 , b. $498,1.1$. 
atsirasti didesnių ar mažesnių nesklandumų. Siekiant, kad, prireikus ją vykdyti, nebūtų netikètumų, reikejo praktiškai patikrinti (tai ir buvo pagrindinis šios bandomosios mobilizacijos tikslas):

1. kiek iš viso Lietuvos kariuomeneje priimta mobilizacijos sistema tinkama, pirmiausia - jos nustatyta tvarka, kuria: a) mobilizuojami atsarginiai savarankiškai vyksta tiesiai ị kariuomenès dalinius; b) patys gyventojai pristato kariuomenès daliniams jos registruotą turtą; c) atsarginius ir gyventojų pristatomą turtą priima daliniuose pareigūnai (be komisijų); d) mobilizacija pradedama vykdyti ne 00 val. 01 min., o bet kuriuo paros metu;

2. nustatyti pasirengimo mobilizacijai ir jos vykdymo trūkumus minètoje rinktinejje;

3. igyvendinti duonos kepimo planą Kupiškio iguloje ir

4. paskatinti stropiau rengtis mobilizacijai ir ją vykdyti.

Kad galiojantis mobilizacijos planas nebūtų atskleistas, bandomoji mobilizacija buvo vykdoma pagal atskirai parengtą Aukštaičių rinktinès mobilizacijos planą. Pagal ši planą taikos meto sudèties 4-ojo pèst. pulko I batalionas ir 1-ojo artilerijos pulko III grupe buvo performuoti i karo meto sudèties pèstininkų pulką ir artilerijos grupę.

I bandomąją mobilizaciją buvo įtraukti šie valsčiai:

Panevėžio apskrityje: Kupiškio, Šimonių ir Viešintų;

Rokiškio apskrityje: Skapiškio, Pandèlio, Panemunio, Panemunèlio, Kamajų, Svėdasų ir Južintų;

Biržų apskrityje: Vabalninko ir Papilio.

Atsargos karininkai buvo pašaukti iš I pèst. divizijos teritorijos ir Kauno miesto.

Raštiškas mobilizacijos įsakymas I pėst. divizijos vadui buvo įteiktas 1937 m. spalio 21 d. 15 val. Mobilizacijos stebejjimui palengvinti šioje reliacijoje visur nurodytas jau pakeistas laikas - visoje Aukštaičių rinktinejje ir visose mobilizacijoje dalyvavusiose îstaigose (komendantūrose ir valsčiuose) mobilizacijos pradžia buvo laikoma $1937 \mathrm{~m}$. spalio $21 \mathrm{~d}$. 15 val., kitaip tariant, laikas, kai I pèst. divizijos būstinèje buvo gautas mobilizacijos įsakymas.

00 val. 45 min. Aukštaičių rinktinès štabe buvo gauta I pėst. divizijos vado telegrama: „Vykdyti Aukštaičių rinktinès bandomąją mobilizaciją.“

Bandomosios mobilizacijos vykdymo ịsakymas buvo perduodamas telefonu, telegramomis, telefonogramomis, pasiuntinių - seniūnams, 
kurie turejjo itteikti šaukimo lapelius ir raginimus, kai kur tam darbui buvo pasitelkiami ir šauliai. Valsčių savivaldybès ir seniūnai ši darbą atliko tinkamai, o pastarieji dar ir gana greitai.

Nors Aukštaičių rinktinès plane buvo numatytas ir apgyvendinimo laikas, tačiau kai kurie dalinių vadai ir mobilizacijai vykstant dar ji keitè. $\mathrm{O}$ to negalèjo būti. Patalpų klausimas turejo būti išspręstas sudarant mobilizacijos planą. Atitinkami pareigūnai privalèjo su juo susipažinti dar taikos metu ir, pasikeitus aplinkybèms, jame padaryti pakeitimus.

I kai kuriuos dalinius paskirti kadrai velavo. Turto išdavimas iš pulko sandèlių vyko tvarkingai ir pakankamai greitai ${ }^{187}$.

Aukštaičių rinktinei suformuoti buvo pašaukta:

a) pèstininkų: karininkų - 71, kareivių - 3414 ;

b) artileristų: karininkų - 15, kareivių - 529 .

Atvyko:

a) pèstininkų: karininkų - 65, kareivių - 2990 ;

b) artileristų: karininkų - 12, kareivių - 456 .

Iš piliečių imamo turto pristatymas sklandžiai nevyko. Buvo nemažai klaidžiojimo, o tai kèlè gyventojų nepasitenkinimą ir rodè menką kariuomenès organizacini pajègumą. Patys gyventojai savo turtą pristatė greitai, gabeno noriai ir su entuziazmu. Tačiau daliniuose nebuvo gerai apgalvota, kaip žmones aprengti, kaip išduoti jiems skirtą turtą - trūko sistemos ir planingumo.

Dèl duonos kepimo kepyklų savininkams neduota jokių nurodymų, nors tai reikejjo padaryti. Todèl šioje srityje mobilizacijos plano įvykdyti nepavyko. Rinktinei leidžiantis ị žygi reikejo turèti apie 15000 duonos davinių, o iškepta jų buvo tik apie 4500 , t. y. apie 30 proc. reikiamo kiekio. Ne visi daliniai turëjo virejjų. Buvo ir kitų nesklandumų ${ }^{188}$.

Visos Aukštaičių rinktinès veikiančiąją priešlèktuvinę apsaugą sudare tik vienas automatinių pabūklų būrys. To buvo per maža. Šiai funkcijai atlikti reikejo ir buvo galima panaudoti dalinių turimas ugnies priemones.

Priešchemine apsauga apskritai nepasirūpinta: jos nebuvo nei mobilizacijos plane, nei bandomajai mobilizacijai jau vykstant. Jokių priemonių nesiimta ir priešgaisrinès apsaugos srityje.

${ }^{187}$ Ten pat, 1. 2-6.

188 Ten pat, $1.8,10-13,15,17$. 
Spalio 23 d. 11 val. 30 min. buvo paskelbta Aukštaičiu rinktinès demobilizacija. Ji truko 6-7 valandas. Dèl mažo pareigūnų skaičiaus ir jų nepatyrimo buvo netvarkos, skubotumo.

Aukštaičiu rinktinès vykdant bandomąją mobilizaciją patirtos išlaidos: pèstininkų pulko - 21582,45 lito, artilerijos grupès - 8108,62 lito, iš viso $-29092,07$ lito $^{189}$.

Bandomoji mobilizacija parodè, jog vadovybès nustatyta sistema gera ir, pašalinus pastebètus trūkumus, galima tikètis ją sklandžiai atlikti per 30 valandų. Faktiškai visi mobilizacijos darbai buvo baigti ir Aukštaičių rinktinè pasiruošè uždavini vykdyti: a) pėstininkų pulkas - per 29 val., b) artilerijos grupé - per 33 val.

Siekiant pašalinti trūkumus ir ateityje išvengti panašių klaidų ir nesklandumų, reikèjo, kad visi atsakingi organai daugiau dèmesio skirtų mobilizacijos planų rengimui ir kontrolei. Tik kruopščiai parengtas ir gerai apgalvotas planas galèjo būti sklandžiai ịvykdytas.

Praktika parodè, kad tokia bandomoji mobilizacija tiek ją rengusiems, tiek vykdžiusiems davè daug naudos. Todèl ir ateityje panašias bandomąsias mobilizacijas nutarta rengti. Stebint mobilizaciją vietoje ir iš vèliau gautų pranešimų-ataskaitų matyti, kad tiek mobilizaciją vykdę pareigūnai, tiek atsarginiai ir turto pristatytojai parode daug geranoriškumo ir atsidavimo. Daug kur žinia apie bandomąją mobilizaciją buvo priimta kaip pranešimas apie tikrą mobilizaciją, todèl išvykstantys atsarginiai artimujjų buvo apraudoti. Tačiau tai nesudrumste bendros nuotaikos, dèl to nepasitaikè vengimo atlikti pareigą atvejų - visi rinkosi noriai, pakiliai nusiteikę.

Ši bandomoji mobilizacija, be kita ko, parodè, kad plačiujjų gyventojų sluoksnių pareigos supratimas ir tautinio susipratimo jausmas pakankamas, todèl tikètasi, jog prireikus jie pasirodys ne blogiau, negu šio bandymo metu ${ }^{190}$.

Kariuomenès vadas brg. gen. S. Raštikis 1937 m. gruodžio 27 d. nurodè divizijų vadams, ginklų rūšių ir tarnybų viršininkams, pulkų vadams ir apskričiu komendantams pastebėtus mobilizacijos trūkumus pašalinti, o mobilizacijos planus pataisyti ${ }^{191}$.

\footnotetext{
189 Ten pat, 1. 19-20.

190 Ten pat, 1. 21.

191 Ten pat, 1. 1.
} 


\section{Kariuomenès manevrai}

Didinant kariuomenès dalių kovinę galią ir gerinant jų pasirengimą galimai Lenkijos agresijai atremti, beveik kasmet buvo organizuojami didesnio ar mažesnio masto manevrai. XX a. trečiajame dešimtmetyje dažniausiai jie vykdavo Varénos poligone. Tačiau kelerių metų kariuomenès gyvenimo praktika parodè, kad šis poligonas dèl daugelio priežasčių nebeatitiko laiko keliamų reikalavimų ${ }^{192}$.

Atsižvelgus ị visa tai, naujam poligonui buvo pasirinkta vieta ị pietryčius nuo Jonavos, Gaižiūnų, Ruklos dvaro, Gegužinès, Lomenų ir Levintų vietovių. Nors ir būta nemažų finansinių ir kitų sunkumų, per keletą metu jis buvo ịrengtas. Poligone iki 1939 m. vèlyvo rudens sèkmingai vyko kariuomenès mokymai ${ }^{193}$.

Išskirtini aptariamojo laikotarpio pabaigoje, 1936 ir 1937 metais, vykę kariuomenès manevrai. Juos organizavo ir jų veiklą kontroliavo kariuomenès vadas gen. št. plk. S. Raštikis ir Kariuomenès štabo viršininkas gen. št. plk. J. Černius.

1936 m. kariuomenès manevrai

Juose dalyvavo ịvairių kariuomenès rūšių dalys. Jos parodė didelę ištvermę ir atsidavimą. Nors del to, kad manevrai vyko greitai, dalyviams nepakako poilsio ir ne visai vykusiai dalyse buvo sutvarkyta mityba, visų nuotaika beveik visą laiką buvo gera. Atsilikusių ir evakuotų karių skaičius buvo minimalus. Vis dèlto pastebèta, kad kai kurių dalių kariai šiek tiek nerangūs ir ištižę, o jų vadams trūksta rūpestingumo.

Pats kariuomenès dalių žygis buvo tvarkingas, tačiau valdymas kai kuriuose kautynių ruožuose neretai nutrūkdavo. Visos ginklų rūšys prastai maskavosi nuo stebëjimo priemonių.

Dauguma vadų sprendimų buvo priimtini, tačiau palaikyti tarpusavio ryšius (ypač su kaimynais) labai dažnai buvo pamirštama. Stokojo igūdžių ir aukštesniụjų štabų darbuotojai. Tačiau žygio metu laiku ir gerai buvo atliekamos kelių žvalgymo ir taisymo užduotys, tinkamai veikè aviacija, tankai, tiksliai buvo panaudoti chemijos būriai.

Apskritai kariuomenès vadovybė manevrus ịvertino patenkinamai,

${ }^{192}$ V. Lesčius, Lietuvos kariuomenès aprūpinimas (1921-1940), Karo archyvas, t. 26, p. $246-247$.

193 Ten pat, p. 248, 255. 
pripažindama jų neabejotiną naudą. Nutarta ateityje tokius manevrus rengti kiekvienais metais.

Kariuomenès vadovybė pastebėtas klaidas suskirstė ị dvi rūšis: a) dèl nepatyrimo ir b) dèl apsileidimo. Su aplaidumu nurodyta ypač griežtai kovoti $^{194}$.

1937 m. kariuomenès manevrai

Juose dalyvavo pèstininkai, artilerija, kavalerija, inžinerija, aviacija, lengvieji tankai, cheminè apsauga, automobilių dalis, šauliai, intendantūra, sanitarija, karo technikos tarnyba ir veterinarijos tarnyba. Manevru dokumentai ir jų eigos planas manevrų vadovybès asmenims ir vyresniesiems tarpininkams buvo išduoti anksčiau, negu iki tol buvo daroma, kad šie pareigūnai turètų daugiau laiko su jais susipažinti, organizuoti pasitarimus, aptarti būsimų manevrų eigą, o prireikus su tarpininkais ir ją pakeisti.

Manevrų dalyviai buvo ištvermingi ir veiklūs. Vis dèlto konstatuota, kad kai kurie svarbesni manevrų etapai nepavyko. Jų priežastys glūdèjo kai kurių aukštesniųjų vadų ir štabų veikloje, nes aplinkybės buvo gana palankios, o mažesnieji vienetai savo uždavinius įvykdè patenkinamai.

Dalių vadams buvo nurodyta stengtis, kad žemesnieji karininkai į manevrus atvyktų geriau pasirengę ir juose būtų energingesni, iniciatyvesni, o su ištižèliais karininkais ir puskarininkiais griežtai kovoti.

Apskritai 1937 m. manevrai vyko daug geriau negu 1936 m. ${ }^{195}$

Lietuvos kariuomenès organizaciją ir ginkluotųjų pajègų skaičių aptariamojo laikotarpio pabaigoje tam tikru mastu apibūdina 5 lentelès duomenys ${ }^{196}$.

\footnotetext{
${ }^{194}$ Pastabos apie 1936 m. kariuomenès manevrus, Kariuomenès štabo 19361205 slaptas aplinkraštis Nr. 16, LCVA, f. 514, ap. 1, b. 258, 1. 48-53.

195 Pastabos dèl 1937 m. kariuomenès manevrų, Kariuomenès vado brig. gen. S. Raštikio 19371218 slaptas ísakymas Nr. 28, ten pat, b. 280, 1. 61-68.

${ }^{196}$ Lentelè sudaryta remiantis Kariuomenès štabo Rikiuotès skyriaus viršininko plk. ltn. J. Musteikio 19370122 duomenimis, LCVA, f. 929, ap. 5, b. 504, 1. 1.
} 
Lietuvos kariuomenès gynybos planai ir priemonès galimai lenkų agresijai atremti 1921-1937 m.

$\frac{.0}{\frac{0}{ \pm}}$

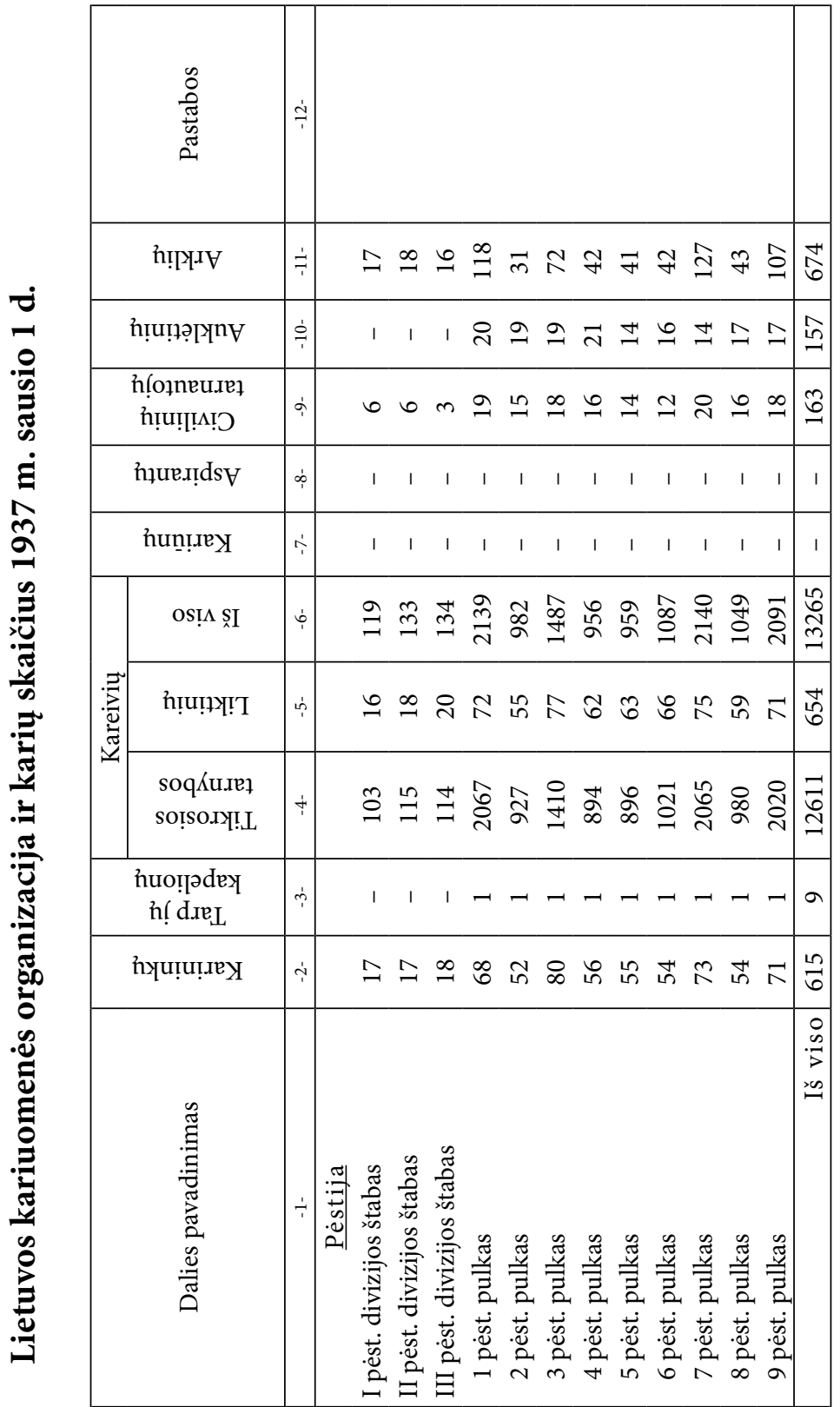




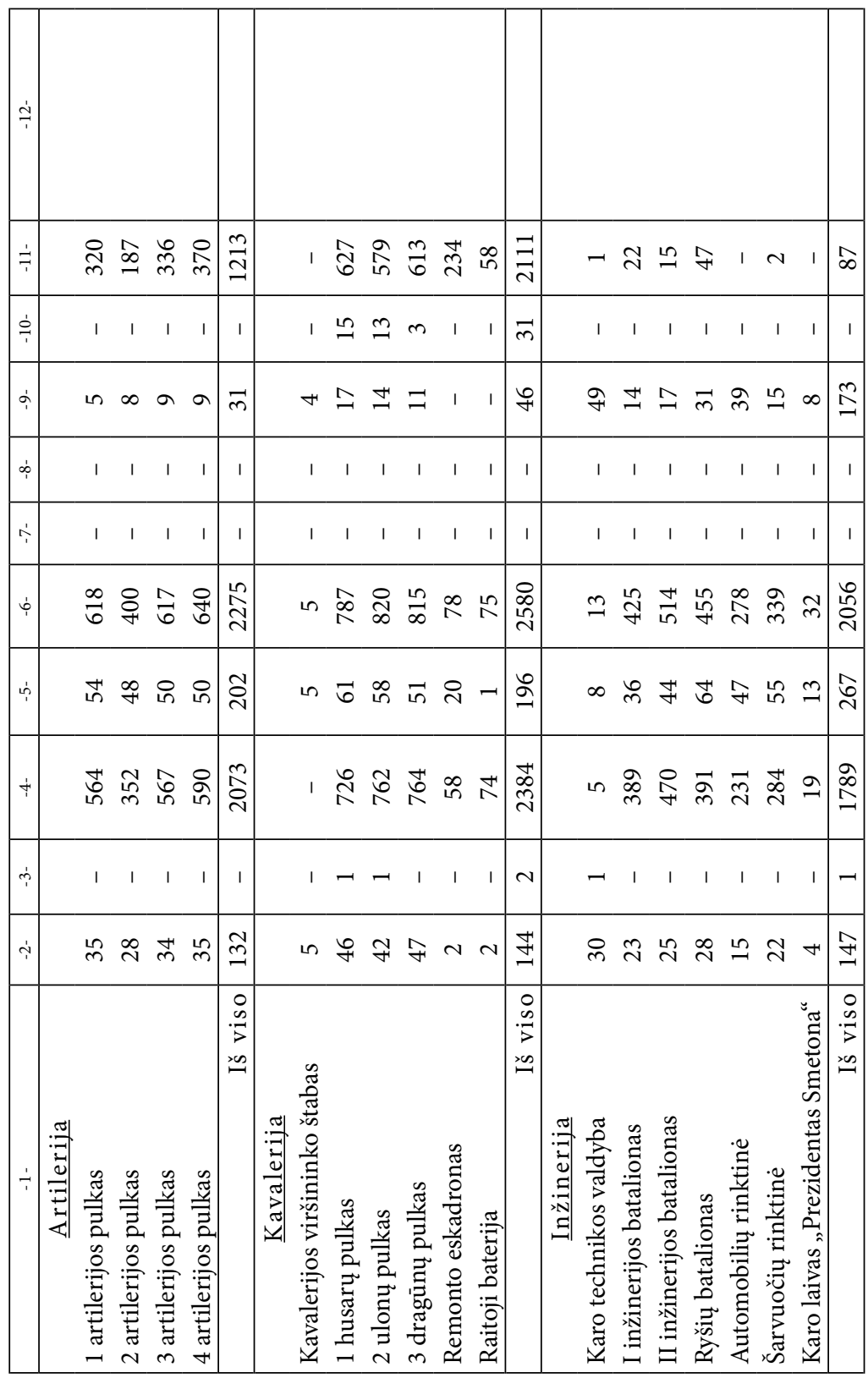


Lietuvos kariuomenès gynybos planai ir priemonès galimai lenkų agresijai atremti 1921-1937 m.

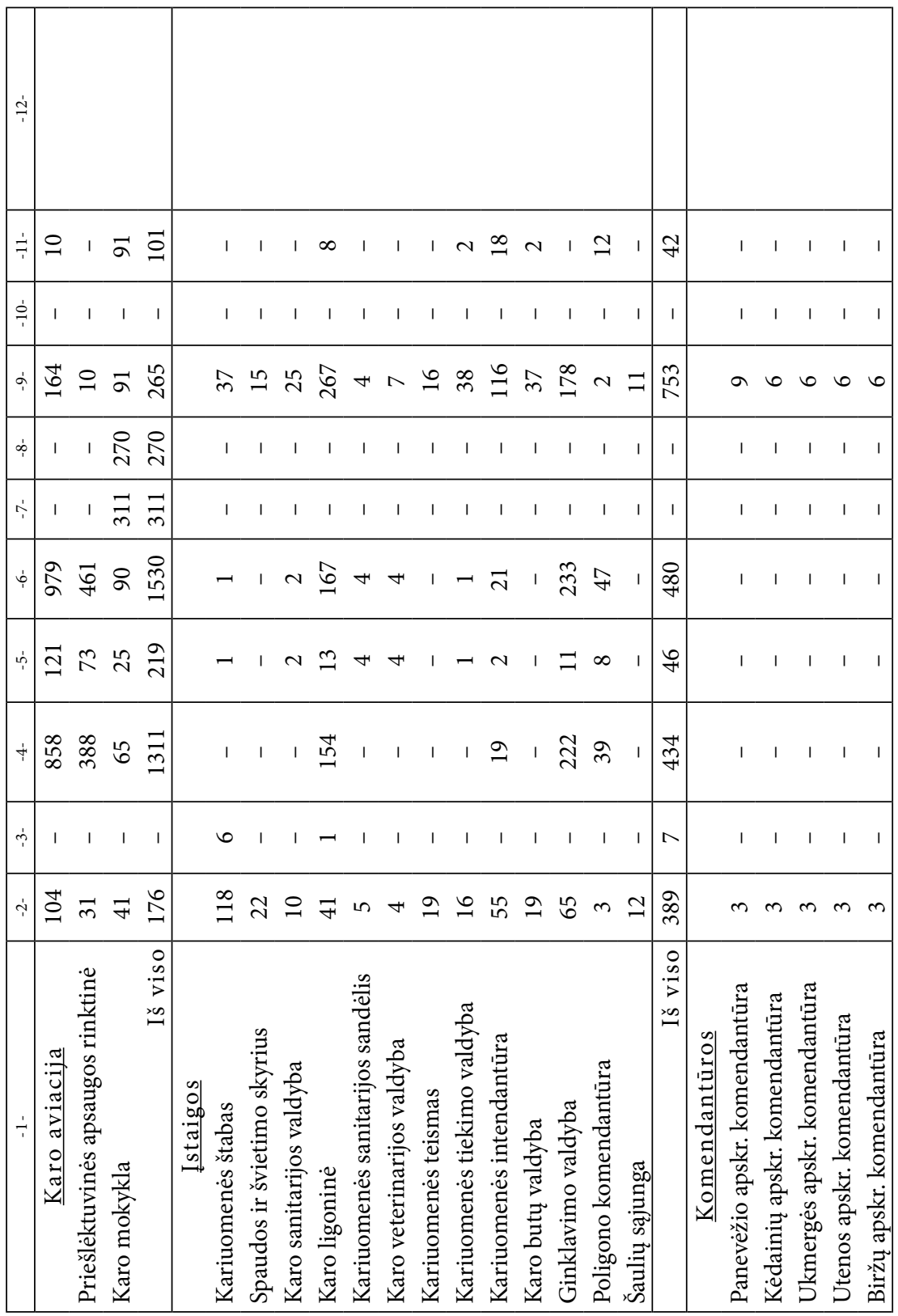




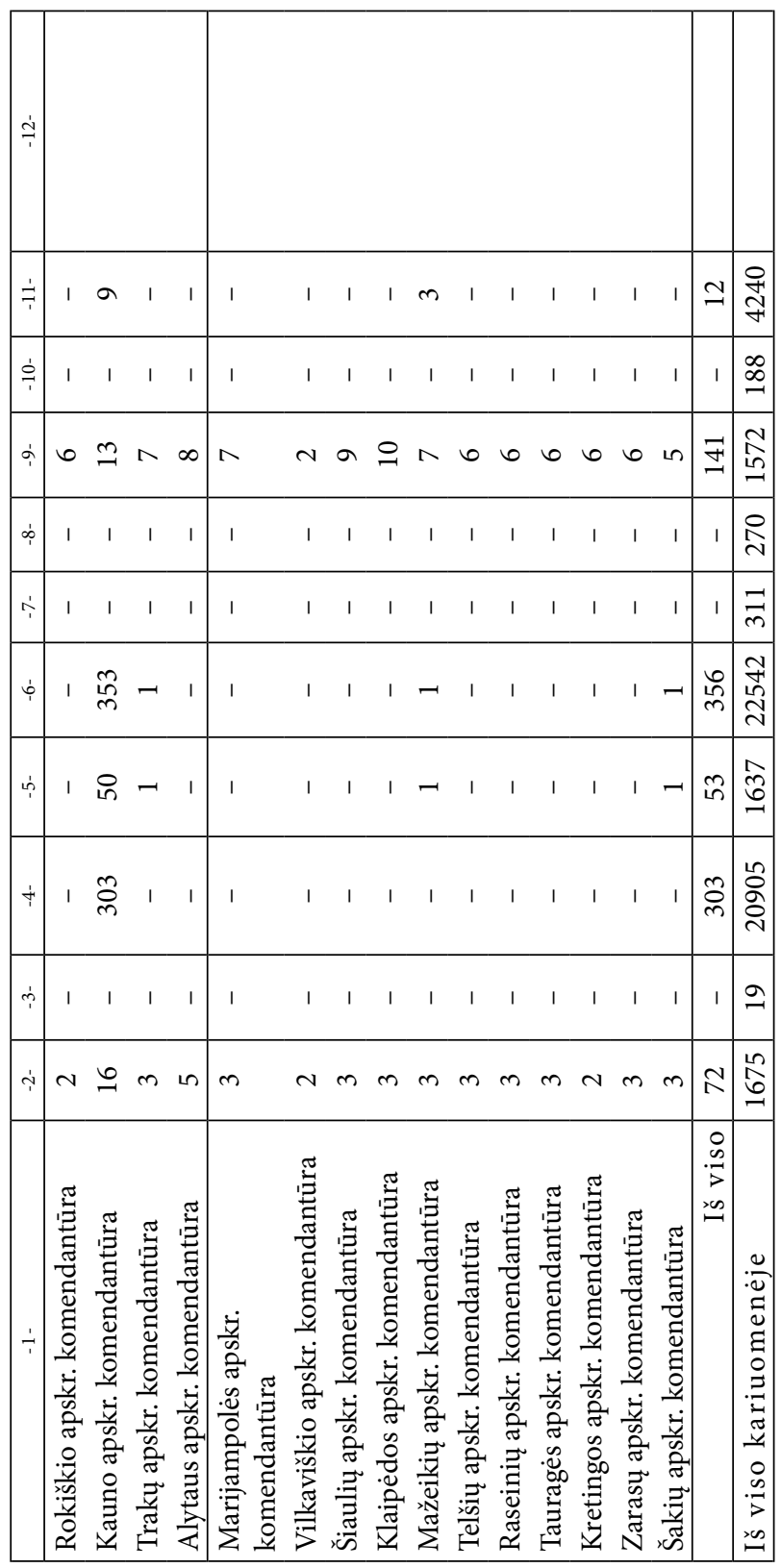




\section{Kariuomenès vado gen. št. plk. S. Raštikio ir štabo viršininko gen. št. plk. J. Černiaus 1937 m. gegužès mẻn. slaptas asmeninis raportas krašto apsaugos ministrui plk. S. Dirmantui dèl Lietuvos tarptautinès ir karinès padèties}

Aptariamojo laikotarpio pabaigoje Europoje, kaip žinoma, vis labiau ryškejjo naujo karo grèsmè. Tai buvo akivaizdu ne tik Lietuvos aukštiesiems politiniams sluoksniams, bet ir jos karinei vadovybei bei plačiajai visuomenei. İvertindamas sparčiai besikeičiančią padètí, Lietuvos kariuomenès štabas $1937 \mathrm{~m}$. pavasarị slaptame asmeniniame raporte krašto apsaugos ministrui atkreipè jo dèmesị $\mathfrak{i}$ tai, kad tiek kariuomené, tiek užsienio politikos aparatas, tarnaudami bendram tikslui - valstybès saugumui užtikrinti, savo praktinèje veikloje negali būti labai atitrūkę vienas nuo kito. Priminta, kad Lietuvos kariuomenei tektų veikti tokiomis politinėmis aplinkybėmis, kurias sukurtų mūsų diplomatija. O kariuomenei ne vis vien, kokios bus tos aplinkybès, nes jos pajègumai labai riboti. Todèl diplomatija, ruošdama dirvą savo kariuomenei, turèjo išgirsti ir kariuomenès vadovybès balsą, kokios politinès aplinkybès būsimai kariuomenès veiklai būtu palankesnès, o kokios - ne.

Kariuomenès štabo nuomone, ilgą laiką Lietuvos užsienio politika saugumo požiūriu buvo pagrịsta dideliu pasitikèjimu tomis garantijomis, kurios buvo teikiamos Lietuvai kaip Tautų Sajungos narei: buvo manoma, jog Tautų Sąjunga mūsų pavojingiems kaimynams toliau grasinimų neleis nueiti. Gal tokia politika ir buvo pagrista, nes Lietuvai pavojingi 1928 ir 1935 metai tikrai praejjo laimingai. Tačiau vèlesni ịvykiai ir visų šalių intensyvus ginklavimasis aiškiai rodė Tautų Sąungos galimybių ribotumą ir pasitikèjimo ja mažèjimą. Šių ịvykių eigą daugiausia nulèmé didžiųjų valstybių interesai ir jų karinio pasirengimo laipsnis.

Kariuomenès štabas buvo ịsitikinęs, kad didžiųjų kaimyninių valstybių - Lenkijos ir Vokietijos - tuometis pasirengimas visiškai pakankamas ir kad kiekviena iš jų, vien tik su Lietuva kariaudama, lengvai galètų ją užgrobti. Tačiau tuo metu dar neturèta tvirtos nuomonès, ar šių kaimynų interesai pakankamai svarbūs, kad jie galètų Lietuvą pulti ${ }^{197}$.

${ }^{197}$ Kariuomenès štabo vadovybės 1937 m. gegužès mèn. slaptas asmeninis raportas kraš- 
Manyta, jog: 1. Lenkijai kariaujant su Sovietų Sąunga ar Vokietija, Lietuvos teritorija būtų likusi nuošaly. Atsižvelgiant $\mathfrak{i}$ to meto Lietuvos ir Lenkijos santykius, tokia padètimi galèjo pasinaudoti tiek Lietuvos, tiek Sovietų Sąungos, tiek Vokietijos kariuomenès, smogdamos ị Lenkijos pajègų sparną ir užnugarị.

2. Vokietijai užgrobus Lietuvą, Lenkijos, palyginti su Vokietija, strateginè padètis būtų labai pablogèjusi: pailgèjusi jau ir taip ilga pavojinga siena su Vokietija, sustiprètų Vokietijos karinė bazė rytuose, lyg kabantis Damoklo kardas grasinusi Lenkijai.

Lietuvos kariuomenès štabo vadovybès nuomone, šie du argumentai būtų buvę patys svarbiausi Lenkijos politikai Lietuvos atžvilgiu orientuoti. Kaip Lenkija šiems pavojams galejo užbègti už akių? Tai buvo galima padaryti dviem būdais:

a) patogiu politiniu momentu, kai mažiausia kitų suinteresuotų valstybių ịsikišimo grèsmè, Lietuvą užgrobti;

b) įtraukti Lietuvą ị karinę sąjungą su Lenkija arba bent gauti iš Lietuvos patikimą garantiją, kad, kilus Lenkijos ir Vokietijos ar Lenkijos ir Sovietų Sąjungos karui, nei pati Lietuva Lenkijos nepultų, nei sutiktų per savo teritoriją leisti judèti pastarosios priešo kariuomenei, t. y. ginklu gintų savo neutralitetą, o jei tai darydama būtų Vokietijos ar Sovietų Sąjungos puolama, automatiškai taptų Lenkijos sąjungininke.

Tuo metu Lietuvos ir Lenkijos santykiai nebuvo draugiški, todèl manyta, jog pastarajai būtų tikslingiau veikti pirmuoju būdu, t. y. patogiu metu užkariauti Lietuvą. Rasti pretekstą pradèti karą galèjo būti labai lengva: menkiausias ịvykis prie administracinès linijos, griežtas reikalavimas atsisakyti savo pretenzijų ị okupuotają Lietuvos dalị ir t. t.

Kokia šalis galèjo padèti Lietuvai kare su Lenkija? Manyta, kad Vokietija, kurios Rytprūsiai, Lenkijai užgrobus Lietuvą, atsidurtų nepalankioje padètyje gana stiprios Lenkijos apsupti.

Tačiau Vokietija galejjo ir nesikišti i ginkluotą konfliktą, neturèdama garantijų, jog jis bus lokalizuotas ir nesukels prieš ją kitų didžiųjų valstybių. Tokiu atveju Vokietija greičiausiai galètų pasitenkinti anksčiau už lenkus užgrobusi Klaipėdos kraštą ar dar kurią nors Lietuvos teritorijos dalį.

to apsaugos ministrui plk. S. Dirmantui dèl Lietuvos tarptautinès ir karinès padèties, LCVA, f. 929, ap. 3, b. 1136, 1. 1. 
Galvota, jog kitos didžiosios valstybės, ypač suinteresuotos Lenkijos sustiprèjimu, o Vokietijos susilpnèjimu, dèl tokio menko objekto kaip Lietuva $\mathfrak{i}$ Lenkijos ir Lietuvos ginkluotą konfliktą greičiausiai nesiveltų.

Galima buvo numatyti dar vieną atvejị, kai, nepaisant lietuvių taikingų pažadų, Lenkijos pavojus taptų Lietuvai aktualus: jei Lenkija, susitarusi su Vokietija, mėgintų užgrobti Lietuvą, siekdama gauti priejimą prie Baltijos jūros per Klaipèdą mainais už Dancigo koridorių, kuris būtų grąžintas Vokietijai. Tačiau iš tos plačios tuo metu propagandos, kurią pasitelkus lenkų tautai buvo skiepijamas prisirišimas prie turèto pajūrio, ir tụ pastangų, kurias Lenkija dejo savo Gdynès uostui ịrengti ir tobulinti, negalima daryti išvados, kad ji savanoriškai būtų sutikusi atsisakyti turèto priejjimo prie jūros, nebent tai padaryti ją priverstų aplinkybės ${ }^{198}$.

Todèl tuo metu daugiausia tikètasi, jog, suteikus Lenkijai ją tenkinančias garantijas, jos Lietuvai keliamas pavojus būtų eliminuotas ${ }^{199}$.

Kaip matyti, minètose Kariuomenès štabo išvadose tuo metu buvo siūloma palaikyti su Lenkija tam tikrus santykius, nepaisant, kad ši, užgrobusi Vilnių ir kitas Lietuvos žemes, jai buvo padariusi labai didelę skriaudą. Tikètasi minètu pasiūlymu sustiprinti nepriklausomos Lietuvos saugumą, be kurio ir visos kitos jos teisètos pretenzijos netektų reikšmès. Pripažinta, jei minètiems santykiams sukurti ir tektų esamą padètị, kurios Lietuva vis tiek pakeisti negalejo, pripažinti status quo, tai dar nereikštų, kad minètus plotus būtų galima atgauti ateityje.

Manyta, jog pageidaujamų santykių su Lenkija užtikrinimas Lietuvai būtų suteikęs privalumų:

1) Palengvinęs šalies kariuomenès operacinị pasirengimą ir leidęs jị nukreipti pagrindine - Vokietijos - kryptimi. Turimus išteklius skaidant dviem vienodai svarbiomis kryptimis, pasirengimo sistemoje susidarytų didelès spragos, nes gintis nuo dviejų priešų būtų buvę neįmanoma.

2) Tai būtų leidę tikètis didesnès Lenkijos paramos Vokietijai bandant kèsintis ị Lietuvos nepriklausomybę.

3) Pagerejjus Lenkijos ir Sovietų Sąjungos santykiams, atsirastų galimybė iš jų laukti Lietuvos neutraliteto garantijų.

Aptariamojo raporto pabaigoje užsiminta apie situaciją, kurioje Lietuva atsidurtų Sovietų Sąungos ir Vokietijos karo atveju. Toks karas be

198 Ten pat, 1. 2-3.

199 Ten pat, 1. 4. 
Lenkijos atrodè neįmanomas, nesvarbu, kurioje puseje ji dalyvautų, maža vilties, kad Lietuvos teritorija kariaujančiųjų būtų aplenkta. Greičiausiai ir ji būtų virtusi karo lauku. Lietuva dar šio karo išvakarèse turètų būti apsisprendusi, kurioje pusèje dalyvaus, nes kovoti su priešu, kuris pirmas įsiverš ị jos teritoriją, vadinasi, pasikliauti aklu atsitiktinumu.

Be minètų samprotavimų, Kariuomenès štabas krašto apsaugos ministrui teigè, kad Lietuva turètų prisijungti prie tos pusès, kuri turès daugiausia galimybių karą laimèti. Jo nuomone, mažiausiai galimybių Lietuvai likti nepriklausoma būtų tuo atveju, jei karą laimètų Vokietija. Iš to darytina išvada - Lietuvai reikia eiti išvien su tomis valstybėmis, kurios nenori Vokietijos ekspansijos (Sovietų Sąjunga, Baltijos, Mažosios Santarvès valstybėmis, Lenkija, Anglija, Prancūzija) ${ }^{200}$.

Kaip matyti, aptariamuoju laikotarpiu bene didžiausią grèsmę Lietuvai kèlè jos atžvilgiu agresyviai nusiteikusi Lenkija, niekaip nenorinti susitaikyti su mažos kaimyninès valstybės savarankiškumu ir siekiu susigrąžinti prarastą Vilnių ir kitas teisètas etnografines lietuvių žemes. Lenkijos ginkluotųjų pajègų organizaciją šio laikotarpio pabaigoje iš dalies atspindi prieduose pateiktos schemos (žr. 2-6 priedus).

Pačioje laikotarpio pabaigoje, kylant naujo karo grèsmei, ėmè ryškèti ir kitų kaimyninių valstybių Lietuvai keliamas pavojus.

\section{IŠVADOS}

1. Pateikta dokumentiné medžiaga ir jos analize įtikinamai patvirtina ankstesnių Lietuvos praeities tyrinètojų (politikų, diplomatų, mokslininkų ir kt.) darbuose skelbiamus teiginius, kad aptariamuoju laikotarpiu kaimyninès valstybès Lenkijos valdančiųų sluoksnių politika Lietuvos atžvilgiu buvo agresyvi, aneksinè. Tokia ji buvo nuo pat šių šalių valstybingumo atgavimo pradžios iki jų žlugimo XX a. ketvirtojo dešimtmečio pabaigoje. Lenkijos agresyvumas labiausiai pasireiškè politinejje ir karinèje srityse. Lenkijos valdžia, visą ši laiką laikiusi Lietuvą laikina valstybe, èmèsi visų priemonių, kad įsitvirtintų ne tik Vilniaus krašte, bet ir visoje Lietuvoje (brandino agresyvius planus ir rengèsi atitinkamiems veiksmams). Išskirtinis vaidmuo, sprendžiant minètą uždavini, buvo skiriamas

${ }^{200}$ Ten pat, 1. 5-7. 
gausioms lenkų karinio pobūdžio organizacijoms, taip pat Vilniaus krašte ir netoli jo sutelktoms didelèms reguliariosios kariuomenės dalims. Šioms Lenkijos ginkluotosioms pajègoms buvo keliamas uždavinys - vykdyti prieš Lietuvą îvairias provokacijas ir ruoštis galimiems karo veiksmams.

2. 1921-1926 m. Lietuvos kariuomenès vadovybė dèl lenkų vykdytos aiškiai agresyvios politikos buvo priversta nuolat stiprinti savo karinių pajègų potencialą, bandyti ginklu ginti neutraliosios zonos ValkininkųRūdiškių geležinkelio ruožą 1923 m. pradžioje, o aptariamojo laikotarpio pabaigoje - parengti išsamius, gerai motyvuotus gynybos ir ginkluotujų pajėgų pertvarkymo planus, pritaikant juos prie pakitusių sąlygų. Tačiau dèl pasikeitusių aplinkybių krašto viduje jų nepavyko igyvendinti.

3. Po $1927 \mathrm{~m}$. gruodžio $17 \mathrm{~d}$. ịvykusio valstybès perversmo i̇ valdžią atẻjus žinomiems savo antilenkišku nusistatymu tautininkų vadams, prieštaravimai tarp Lietuvos ir Lenkijos dar labiau paaštrejo. Toliau didejo galimos lenkų agresijos, panaudojant ir lietuvių politinius emigrantus - plečkaitininkus, pavojus.

Šiuo laikotarpiu įvyko daug pokyčių ir pačioje Lietuvos kariuomenès vadovybejje. I jos gretas įsiliejo nemažai gabių karininkų, baigusių aukštuosius mokslus užsienio šalių karo akademijose ir savo šalies mokyklose. Eidami vadovaujamas pareigas Vyr. štabe, jo skyriuose, taip pat divizijose ir kariuomenès ịvairių rūšių dalyse, jie sugebejo parengti vadovybei konkrečius operatyvinius sumanymus, ịvairias direktyvas, instrukcijas, planus ir kitus svarbius dokumentus, reikalingus Lietuvos kariuomenei organizuoti lenkų puolimo atveju.

Gerinant kariuomenès kovinị rengimą kasmet buvo organizuojami ivairaus masto manevrai. Aptariamojo laikotarpio pabaigoje pradèta rengti bandomąsias mobilizacijas. Isstengta gerokai pagerinti kariuomenès apginklavimą ir jos materialinị aprūpinimą.

4. Sparčiai stiprinti kariuomenès gynybini pajègumą vertè ir tai, kad nuo 1937 m. pavasario lenkai palei administracinę liniją pradejjo provokacinius veiksmus. Nors jie tais metais i ginkluotą konfliktą ir neperaugo, $1938 \mathrm{~m}$. kovo $18 \mathrm{~d}$. Lietuvos vyriausybė buvo priversta priimti Lenkijos ultimatumą dèl diplomatinių santykių su ja užmezgimo visiškai nepasirengusi. Šiuo ultimatumu lenkai patvirtino savo imperialistines užmačias Lietuvos atžvilgiu ir norą jas igyvendinti karine jèga. 
2-6 priedai: Lenkijos ginkluotųjų pajėgų organizacija $1937 \mathrm{~m}$.

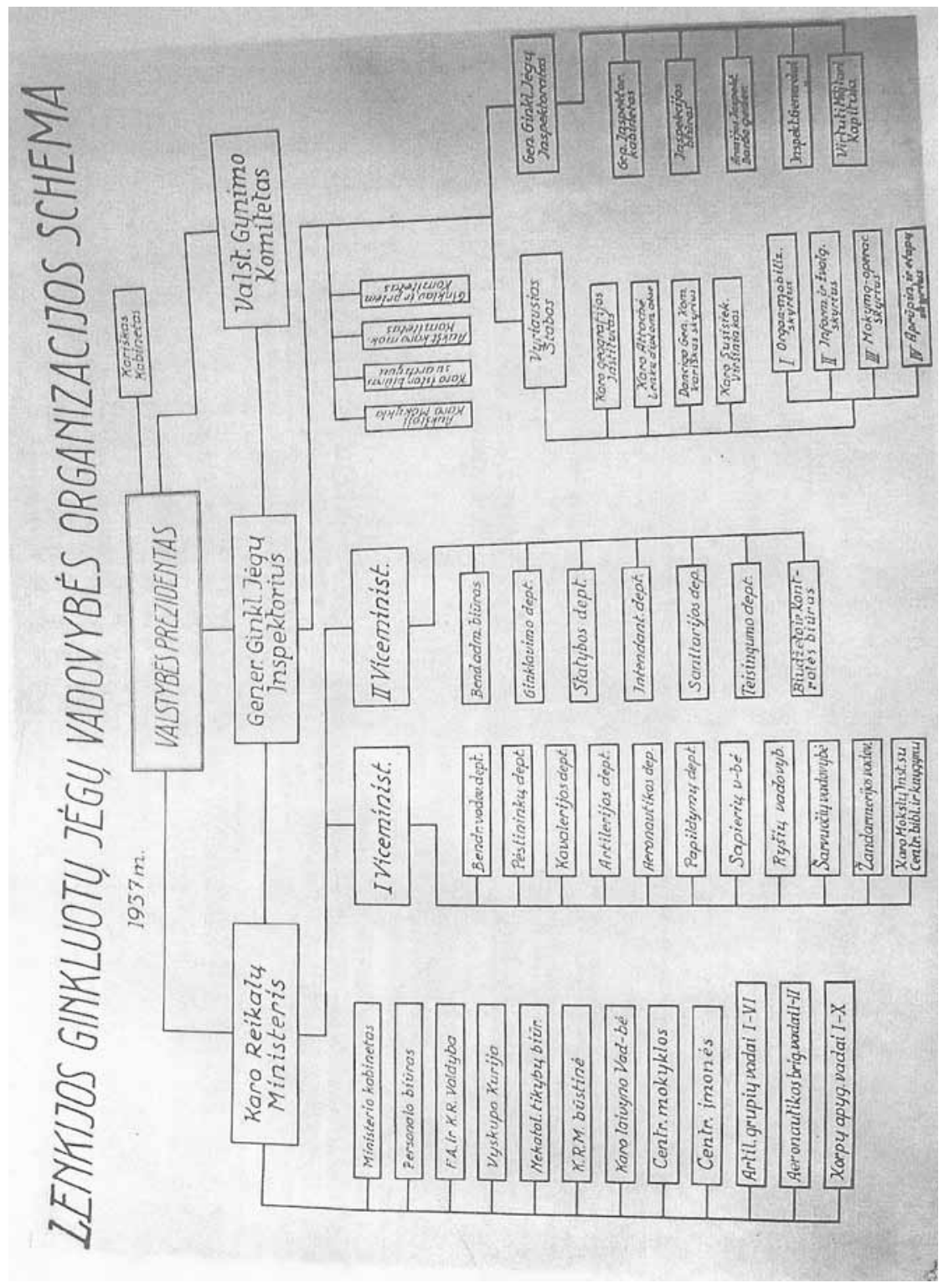


Lietuvos kariuomenès gynybos planai ir priemonès galimai lenkų agresijai atremti 1921-1937 m.

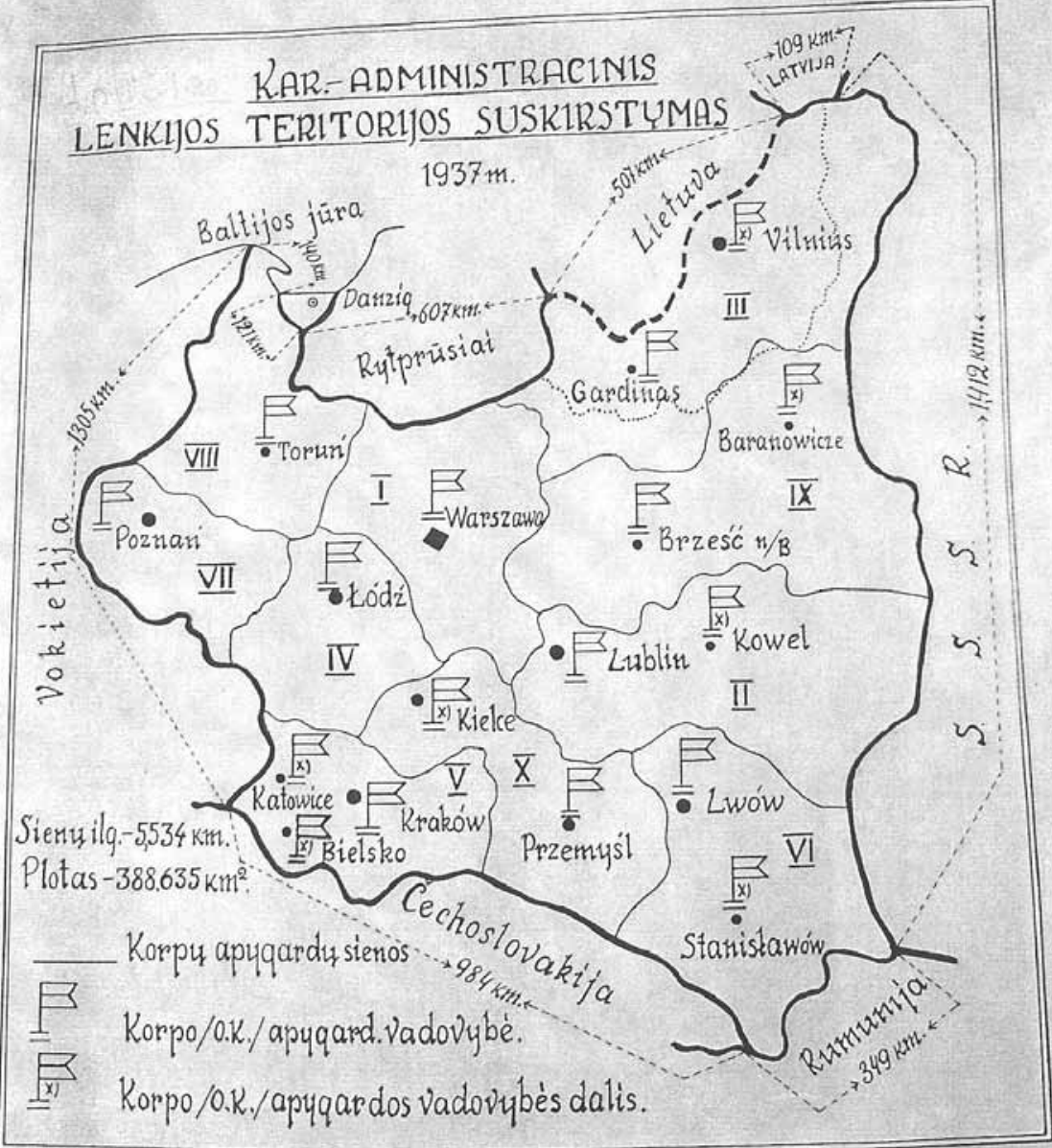




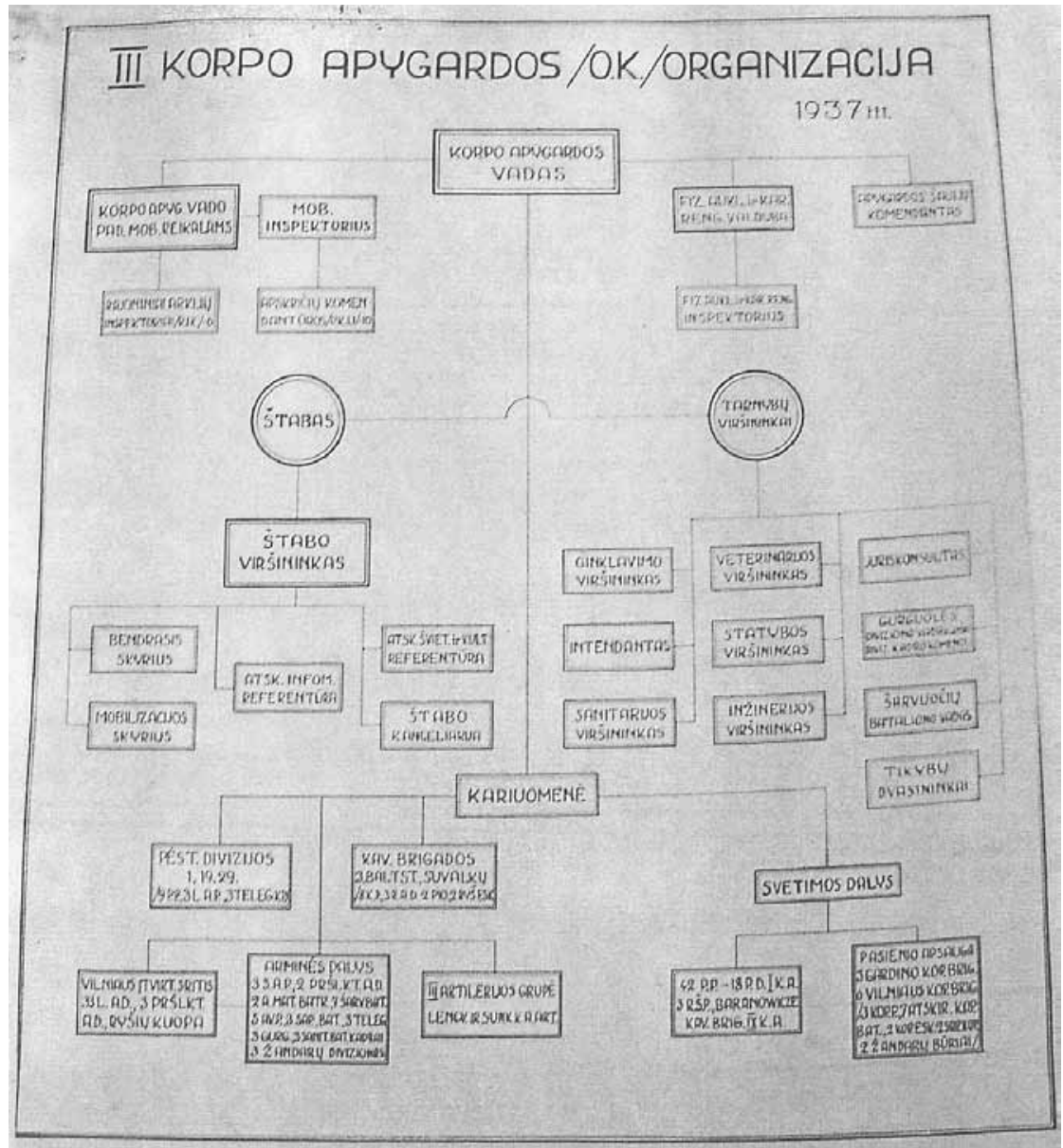


Lietuvos kariuomenès gynybos planai ir priemonès galimai lenkų agresijai atremti 1921-1937 m.

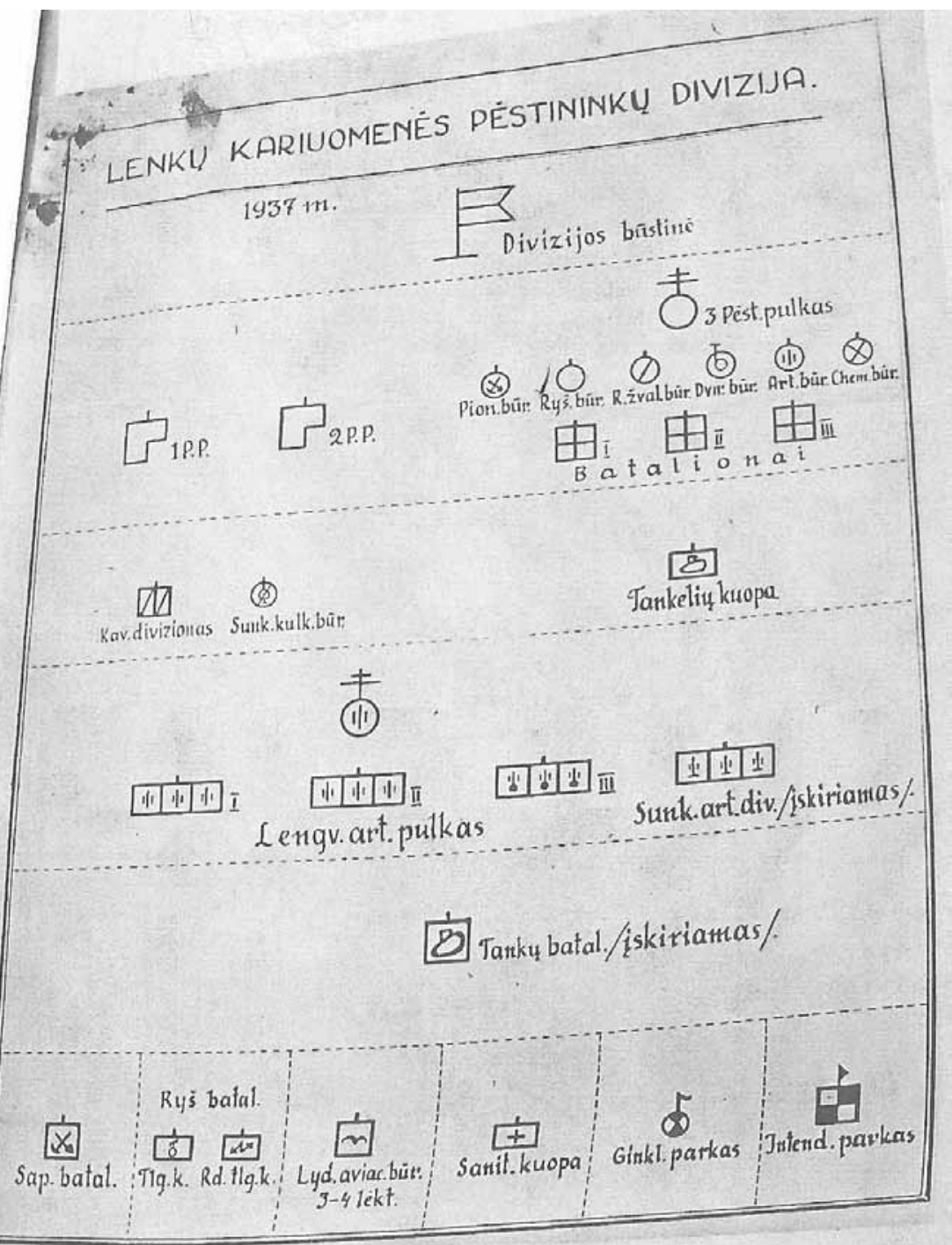


LENKU ATSKIROJI KAVALERIJOS BRIGADA.

$1937 \mathrm{~m}$.
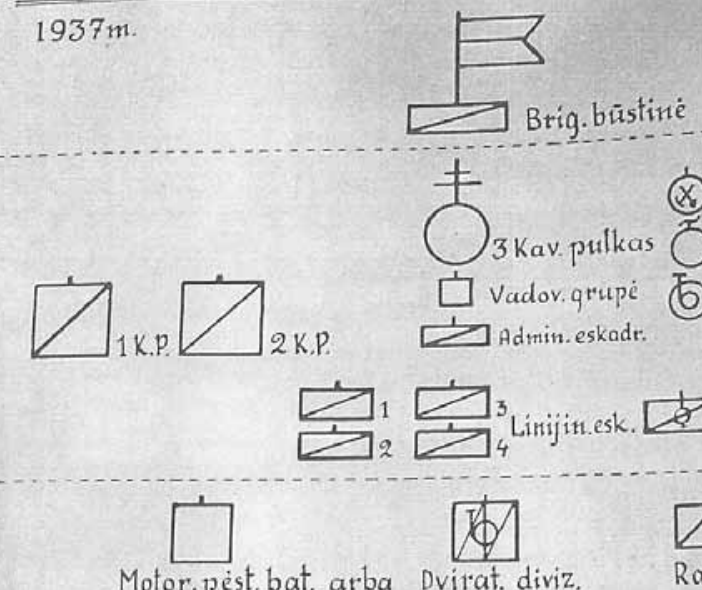

(x) Pionieril birtys

$\square$ Vadov.qrupe

1 Admin.eskadr.

(6) Dviratininku bürys

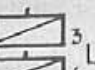

${ }_{4}^{3}$ Linijin.esk. \& Sunk.kulk.eskadr

Motor. atba Dritat. diviz.

\section{Rait. art.diviz.}

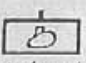

它

(b)

Tankeliy kuopa arba Sarv, auto eskadr. Motocikl. 5urk.kulk. burys.

1x. Pionieriu eskad: $\varnothing$ Rysiy eskadronas

D Lyd. aviac burys

(4) Sanifarinis burtys

Iteikta $2012 \mathrm{~m}$. balandžio $25 \mathrm{~d}$. 


\title{
PLANS ET MESURES DE LA DÉFENSE DE L'ARMÉE LITUANIENNE AFIN DE REPOUSSER L'AGRESSION DES POLONAIS POSSIBLE EN 1921-1937
}

\author{
Maitre dr. Vytautas LESČIUS
}

L'information documentaire et son analyse présentées dans l'article confirme avec conviction les affirmations publiées dans les ouvrages des anciens chercheurs (politiques, diplomates, scientifiques et autres) du passé de Lituanie, que lors de la période mentionné la politique pratiquée par des milieux dirigeants de la Pologne voisine envers Lituanie était agressive. Une telle politique était pratiquée dès le début de la reprise d'État de ces pays voisins et continuait jusquà leurs faillite à la fin de la quatrième décennie du XXème siècle. Cette agressivité polonaise s'exprimait beaucoup dans les domaines politique et militaire. Lors de toute la période mentionnée, l'autorité de la Pologne qui considérait la Lituanie comme un pays temporel, prenait toutes les mesures afin de s'ancrer dans la région de Vilnius, mais aussi elle créait des plans agressifs et les actions pour asservir toute la Lituanie. Le rôle exclusif en solutionnant le problème était destiné pour des nombreuses organisations de la couleur militaire polonaises dans la région de Vilnius et pour les parties de l'armée régulière nombreuses concentrées aux environs de Vilnius. La tache donnée pour ces forces armées polonaises - pratiquer des provocations diverses contre la Lituanie et se disposer pour les actions militaires possibles.

À cause de la politique agressive pratiquée par la Pologne, le Commandement de Lituanie de la période discuté dans les années 1921 - 1926 était obligé de fortifier le potentiel de ses forces armées, et tenter de défendre par la force armée le canton du zone neutre de Valkininkai-Rūfiškès au début des années 1923, pendant quà la fin de la période - de préparer les plans de défense bien motivés et détaillés pour réorganiser les forces armées en les adaptant aux conditions changées. Cependant, son réalisation a échouée à cause des conditions changées au milieu de la région. 
1. Après le bouleversement de l'État du 17 décembre 1927 quand les commandants nationaux connus par son attitude anti polonaise venu, les contradictions entre la Lituanie et la Pologne beaucoup plus s'aggravaient. En plus, le danger de l'agression polonaise augmentait et utilisant les émigrants politiques lituaniens.

Pendant ce période-là, des mouvements distincts se sont passés en même commandement de l'armée de Lituanie. Il était suppléé pas mal par des militaires intelligents ayant l'enseignement supérieur aux académies militaire à létranger ainsi qu'aux écoles dans les pays d'origine. Occupants des charges dirigeantes dans létat-majeur supérieur et dans ses services ainsi que dans les divisions et dans les parties des différentes sortes de l'armée, en cas nécessaires ils étaient capables d'élaborer des conceptions opératives concrètes, des diverses directives, instructions, plans et autres documents importants nécessaires à utiliser en cas de l'invasion des Polognes.

En améliorant la préparation de l'armée pour la lutte, les manœuvres de différentes volumes étaient effectuées. À la fin de la période, les mobilisations probatoires étaient commencées à pratiquer. L'armement de l'armée et son approvisionnement matériel étaient considérablement améliorés.

La force défensive de l'armée devait être fortifiée à cause de la circonstance que depuis le printemps des années 1937, les polonais commençaient à faire des actions provocatrices selon une ligne d'administration. Quoiqu'ils ne sont pas transformés à un conflit armé, mais le 18 mars 1938 le gouvernement de Lituanie était obligé d'accepter l'ultimatum de la Pologne concernant les relations diplomatiques avec ellemême sans aucune exercice. Les polonais donc a confirmait par cet ultimatum ses buts impérialistes envers Lituanie et son désir de l'attaquer par la force armée. 


\title{
PLANS OF DEFENCE AND MEASURES BY LITHUANIAN ARMY TO REPULSE THE POSSIBLE POLISH AGRESSION IN 1921-1937
}

\author{
Doc. dr. Vytautas LESČIUS
}

Documentary material and its analysis provided in this article assuredly confirms propositions published in work of previous researchers of Lithuanian past (politics, diplomats, scientists, etc.) that during the discussed period implemented that politics of ruling circles of neighbouring Poland were aggressive and had plans of annexation towards Lithuania. It was like this from the start when these two neighbouring countries regained their statehood and lasted up until their fall in the end of fourth decade of 20th century. Such aggressiveness of Polish was evidenced the most in political and military spheres. Polish government, treating Lithuania as only temporary country during the whole mentioned period was taking all the measures to not only fixate in Vilnius Region, but also made aggressive plans and actions in order to subjugate whole Lithuania. Exceptional role, when solving the mentioned goal, was given to numerous Polish organizations of military nature as well as to parts or regular army concentrated in Vilnius Region and near it. These Polish armed forces were given a task to implement various provocations against Lithuania and to prepare for possible military actions.

Leadership of Lithuanian army during the discussed period of 1921-1926 because of the clearly expressed aggressive politics that Polish were establishing was forced to systematically strengthen their potential of military forces, try to defend with the force of gun the neutral zone of Valkininkai-Rūdiškiai railway section, at the beginning of 1923, and at the end of this period, to prepare thorough, well-motivated defence plans to reform armed forces, adjusting them to the changed conditions. Unfortunately, because of the changed circumstances inside the region, it was not possible to realize them. After the revolution of the country on 17th of December, 1927 when nationalist leaders known for their 
anti-Polish attitudes came into government, disagreement between Lithuania and Poland became even worse. Possible threat of Polish aggression was getting bigger, using political emigrants of Lithuanians named 'plečkaitininkai'.

During this period many distinct changes appeared even in the office of Lithuanian army itself. Many talented officers joined its side, who had finished their higher education in war academies of foreign countries, as well as schools of their own country. By taking leading positions in army headquarters, its departments as well as in divisions and army parts of various kinds, they, when there were cases of necessity, managed to prepare for the chiefs concrete operative ideas, various directives, instructions, plans and other important documents, which would be needed to use in case Polish would attack them.

In order to improve fighting preparation of the army, each year manoeuvres of various degrees were held. At the end of this period experimental mobilizations were started to be practised. It was managed to noticeably improve armament of the army as well as its material support.

The factor that made rapidly improve defensive force of the army was that from spring of 1937, Polish started provocative action by the administrative line. Even though they did not turn out into armed conflict that year, but on 18th of March, 1938, Lithuanian government was forced to accept ultimatum of Poland about contracting diplomatic relations with it, without any preparation. With this ultimatum Polish confirmed their imperialistic devices towards Lithuania and a wish to solve it with military forces. 